\title{
Impact and Management of Small Farm Dams in Hawke's Bay, New Zealand
}

\author{
By \\ Jan C. Thompson
}

\begin{abstract}
A thesis
submitted to the Victoria University of Wellington in fulfilment of the requirements for the degree of Doctor of Philosophy in Physical Geography
\end{abstract}





\section{Abstract}

In New Zealand, thousands of small dams have been built in agricultural areas for the purpose of providing water storage for stock and/or irrigation. These dams interrupt flow on perennial or intermittent streams; however, almost nothing is known of the downstream impact of these dams on flow regime, water quality, sediment transfer, and channel morphology. The cumulative impact of these dams at the catchment scale is likely to be significant.

The present research was undertaken in the Ruataniwha Plains of Central Hawke's Bay. With further agricultural intensification in the region, it is expected that the construction of small farm dams will continue as farmers try to secure more on-farm water storage. This study attempts to quantify the effects of these storages in two parts: a paired catchment field study to determine the downstream effects of small dams, and a modelling study to investigate the cumulative impact of these storages on streamflow volumes at the regional scale.

Results from the paired catchment field study suggest that the regulation of a small stream by three dams (total storage 11.6 ML) has lowered annual runoff volumes, decreased peak flows, increased periods of low flow, and lengthened the response time of the stream to storm events, as compared to the adjacent unregulated stream. Higher precipitation volumes in the winter act to reduce the degree of these impacts, although flow volumes are still lower as compared to the unregulated stream. Throughout the winter, ponds are full and connected to the downstream system, leading to more days of flow on the regulated stream. The regulation of flow has lowered stream erosion potentials, as evidenced by differences in channel bed sediment and morphological characteristics between the two streams. The regulated channel is aggradational, with no evidence of channel scour found over its length. Water quality changes are also observed, with lower water quality measured in the regulated stream and in the ponds, and generally higher water quality measured in the unregulated stream. 
The impact of farm dams on streamflow in two regional catchments was investigated using two off-the-shelf models (TEDI, Source Catchments). Model predictions suggest that the current volume of farm dam storage has decreased average annual flow volumes in the two catchments by approximately $1 \%$. The predicted streamflow decrease is more significant under scenarios of future agricultural intensification. Regional climate change scenarios do not show a large effect on catchment streamflow volumes. In comparison to known catchment characteristics, the two models have limitations related to some of the model assumptions, and to the inability of the rainfall-runoff model to accurately represent seasonality of flow in the study catchments. On the whole, the models seem to be biased towards underestimating farm dam impact at the regional scale.

The study concludes that farm dams have already influenced catchment streamflow and related processes to some degree. At present, the majority of small farm dams in New Zealand do not require resource consent from local council authorities for construction. It is reasonable to expect that farm dams will continue to be built, and it is important that further construction is undertaken with a sound knowledge of the cumulative impact these dams have on catchment processes and existing streamflow volumes. Proper management will mitigate some of these impacts. Management recommendations include the compilation of an inventory of small dams and their characteristics, continued field investigations, and refinement of a catchment model in order to provide a flexible platform for exploring further management options in the region. This study represents a critical first step towards integrated land and water management in the Ruataniwha Plains and will have relevance for the study and management of farm dams in other areas of New Zealand. 


\section{Acknowledgements}

This thesis was funded in part through a research grant from Hawke's Bay Regional Council, a Victoria University of Wellington PhD Scholarship, and a Professional Development grant from Kwantlen Polytechnic University.

Initial suggestions and assistance in developing my topic were provided by Gary Brierley, Alistair McKerchar, Ross Woods, and Murray Hicks. Graham SevickeJones provided valuable information and assistance, including access to resources at Hawke’s Bay Regional Council. Rob Waldron, Darrel Hall, Michelle Armer, Brett Stansfield, and Kolt Johnson at Hawke's Bay Regional Council and Katrina Browne at Auckland Regional Council also assisted with the provision of information and data. I also thank Greg Wilson, Bay de Lautour, and Elliott Cooper for letting me conduct my research on their farms.

Thank you to all those who assisted me with field work and the general pursuit of all things scientific (and otherwise): Deb Maxwell, Will Ries, Scott Babakaiff, Michael Guggenmos, Hamish McKoy, Ed Challies, Katrin Sattler, John Ballinger, Vicki Addison, Sally Blackwell, Sally Gray, and Peter Tulloch. Thanks also to the rest of my friends and family in New Zealand and Canada who provided valuable support. I could not have finished this without all of you.

I would like to extend my deepest gratitude to my supervisors, Dr. Bethanna Jackson and Professor Michael Crozier, who greatly improved my work through their valuable advice and guidance. This work is dedicated to the memory of Dr. Nick Preston, mentor and friend, whose endless encouragement helped the early stages of my research, and whose love of learning continues to inspire me. 


\section{Table of Contents}

\section{Chapter 1: Introduction}

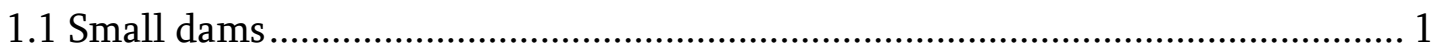

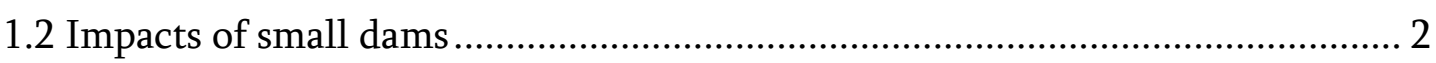

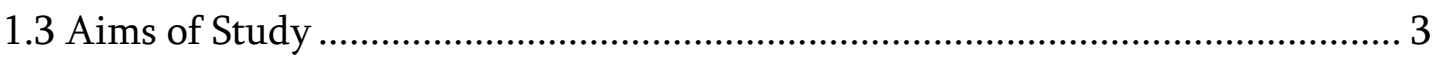

1.3.1 Field-based study objectives ................................................................. 4

1.3.2 Modelling objectives .......................................................................... 5

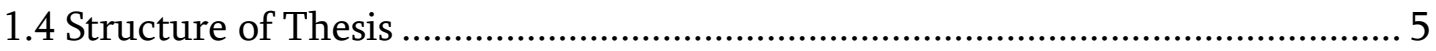

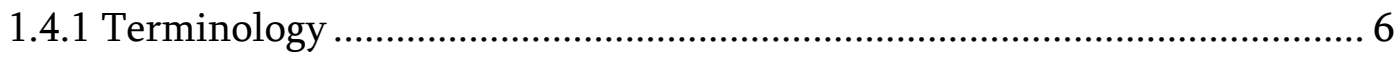

\section{Chapter 2: Background to Study}

2.1 Impacts of small dams ............................................................................... 7

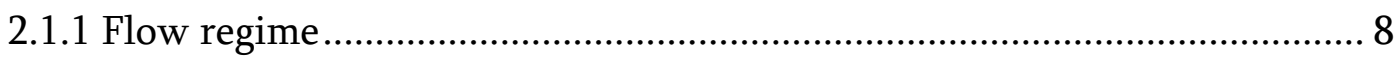

Summary of small dam effects on flow regime ……………………………... 16

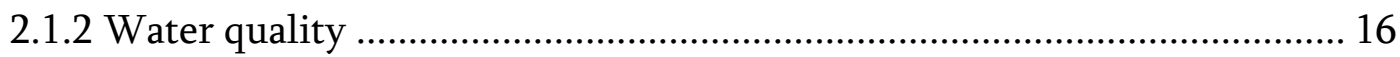

Nutrient inputs from agricultural areas ........................................................ 17

Small dam effects on water quality .............................................................. 19

Summary of small dam effects on water quality ………………………….... 24

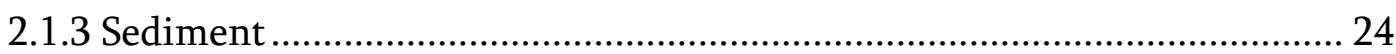

Summary of small dam effects on sediment .................................................. 27

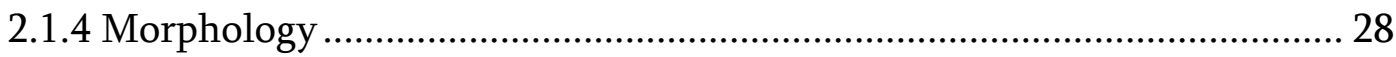

Summary of small dam effects on morphology ……………………………..... 31

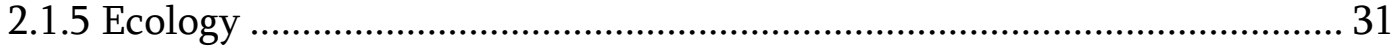

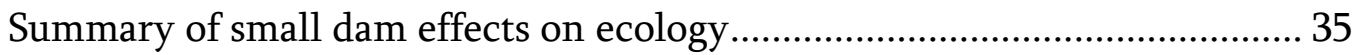

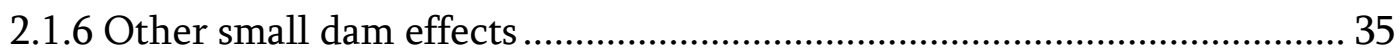

2.1.7 Conclusion of small dam impacts................................................................ 37

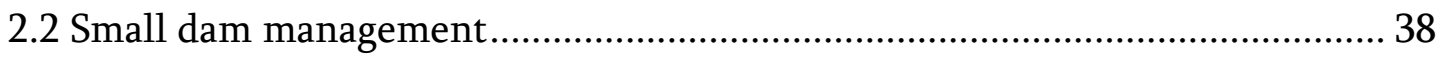

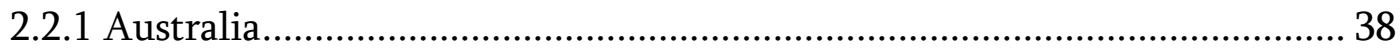

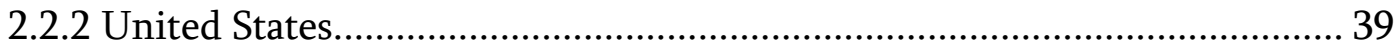

2.3 Water use and management in New Zealand .................................................. 40

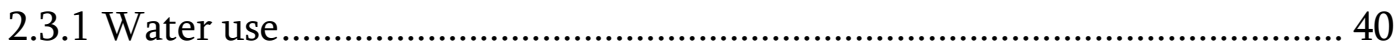

2.3.2 Water management and security …………………………………….... 42

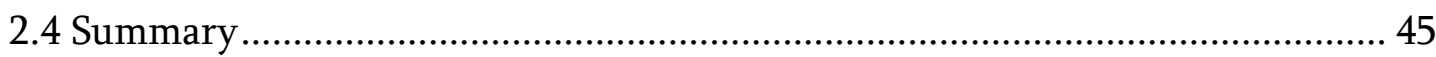


viii

\section{Chapter 3: Location of Study}

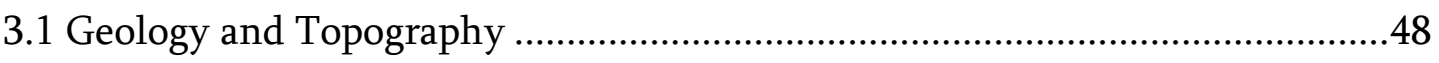

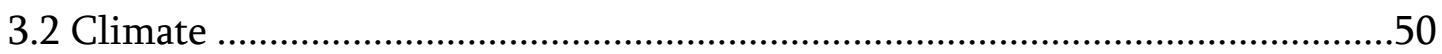

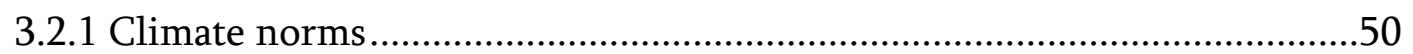

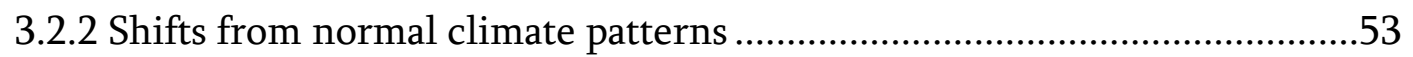

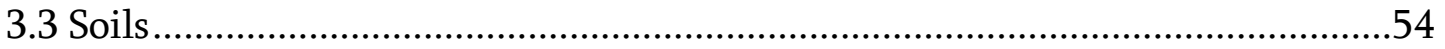

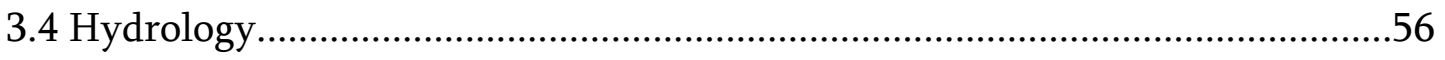

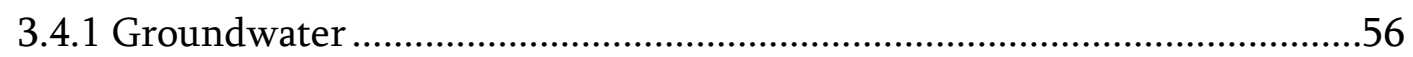

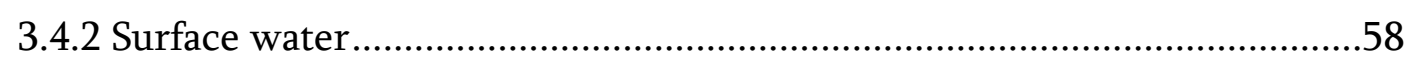

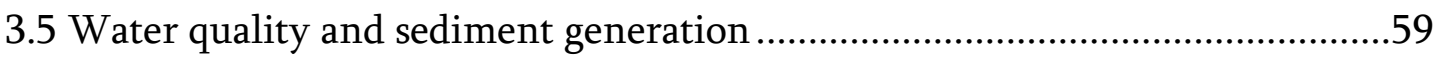

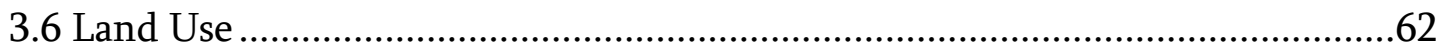

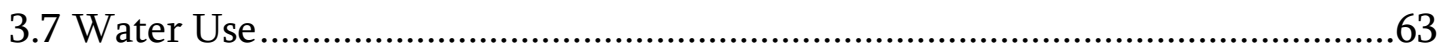

3.8 Water Management on the Ruataniwha Plains .............................................65

\section{Chapter 4: Field Study}

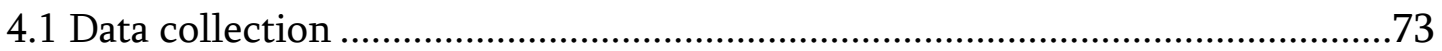

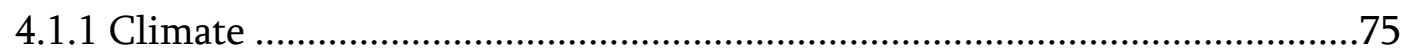

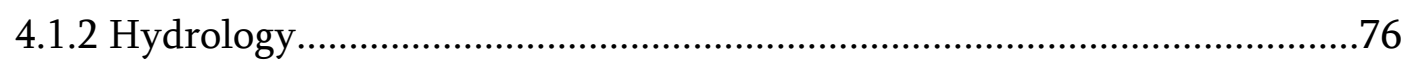

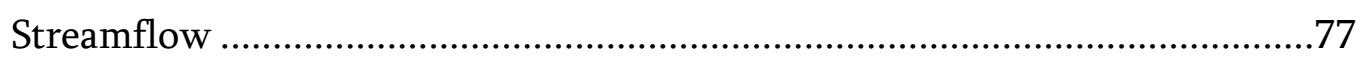

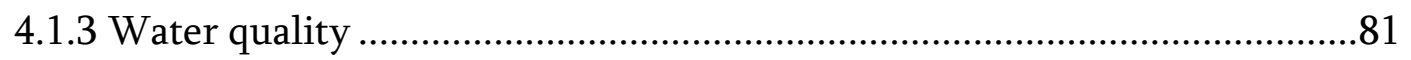

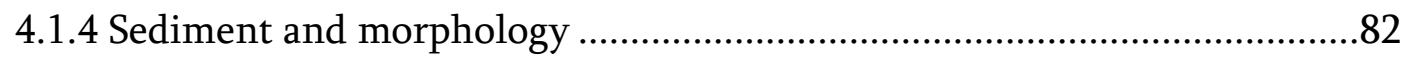

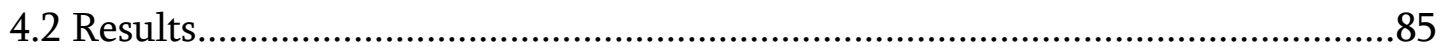

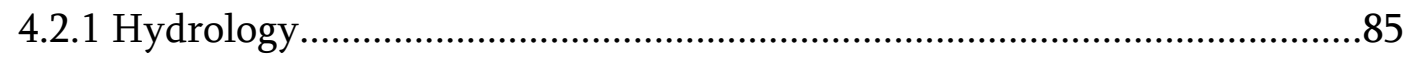

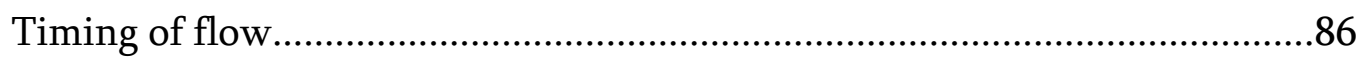

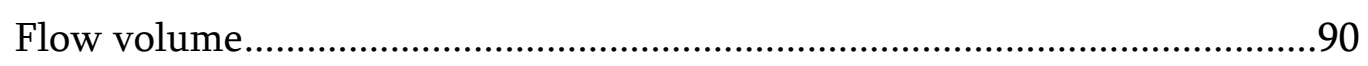

Catchment water balance .........................................................................92

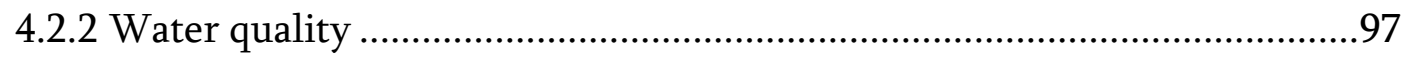

$\mathrm{pH}$

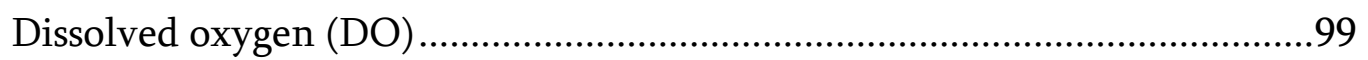

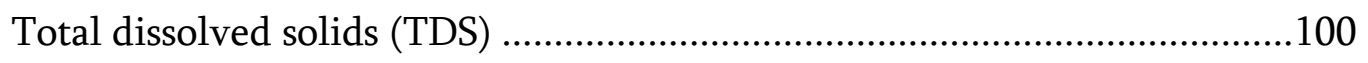

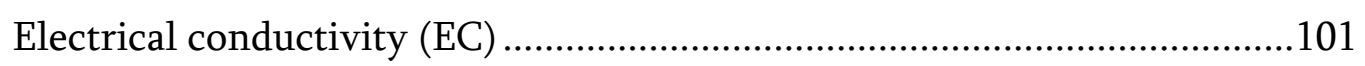

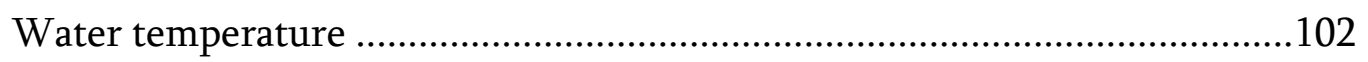

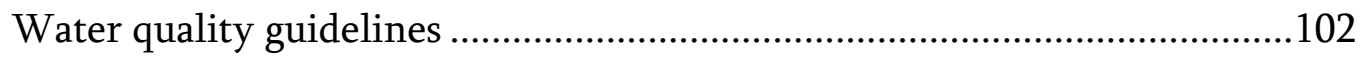




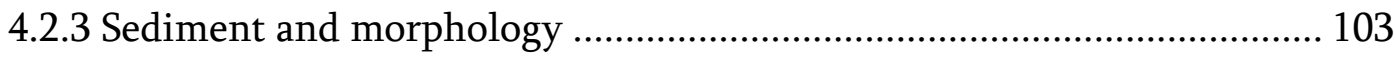

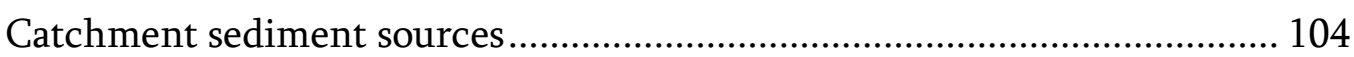

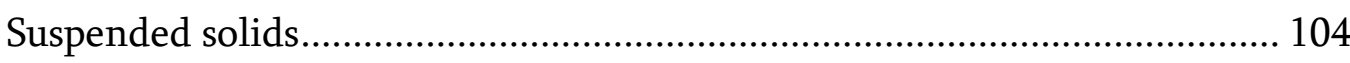

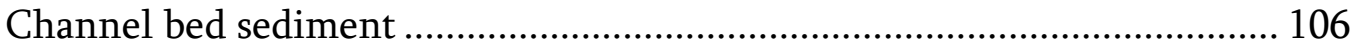

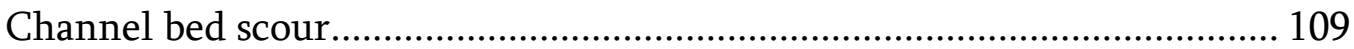

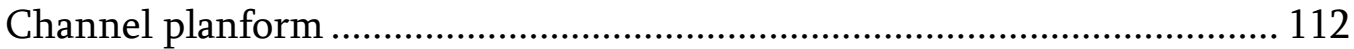

Longitudinal profile and knickpoint location ......................................... 114

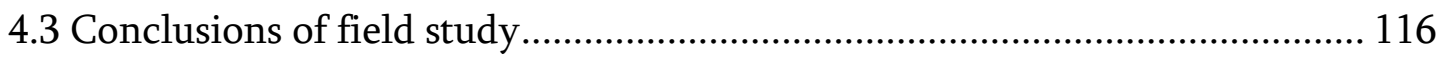

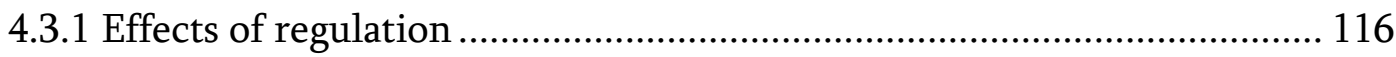

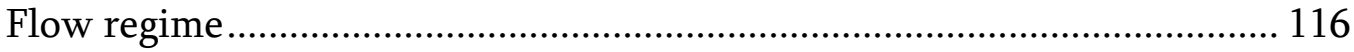

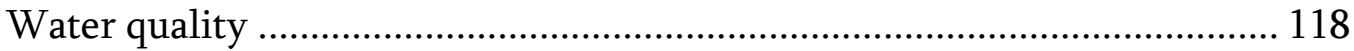

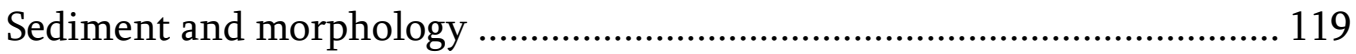

4.3.2 Upscaling results to the regional analysis .......................................... 120

\section{Chapter 5: Regional Study}

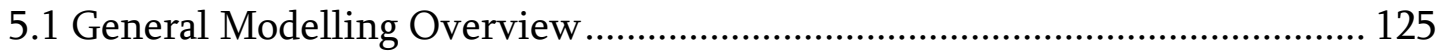

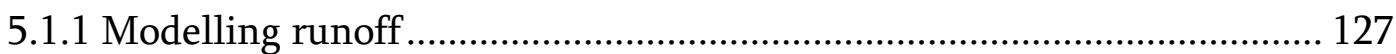

5.1.2 Modelling sediment and water quality .............................................. 128

5.2 Models specifically designed for farm dams ................................................ 129

5.2.1 Tools for Estimating Dam Impacts (TEDI) ............................................ 130

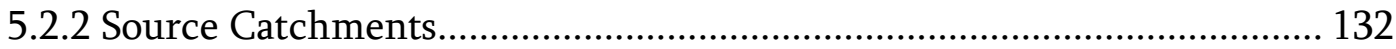

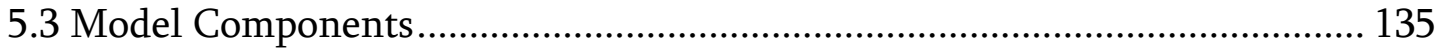

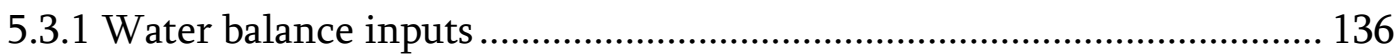

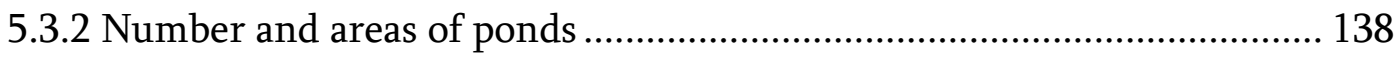

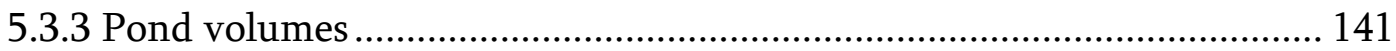

5.3.4 Description of Farm Dams in Catchment .............................................. 144

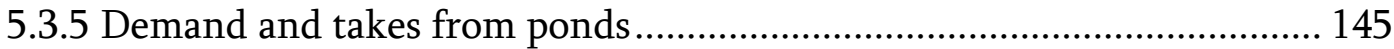

5.3.6 DEM derivation and resolution............................................................. 147

5.3.7 Calibration of AWBM rainfall-runoff model ......................................... 147

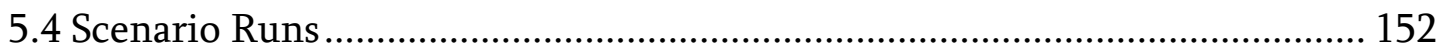

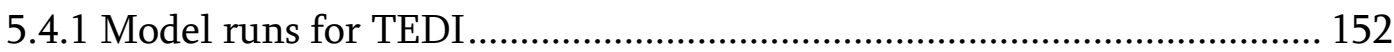

5.4.2 Model runs for Source Catchments...................................................... 154

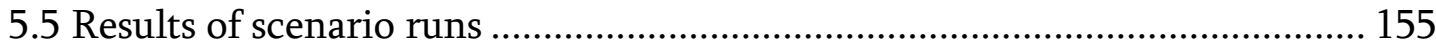




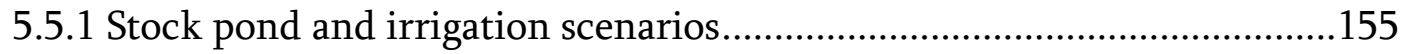

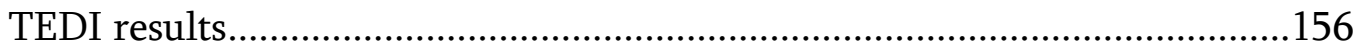

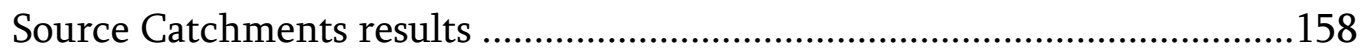

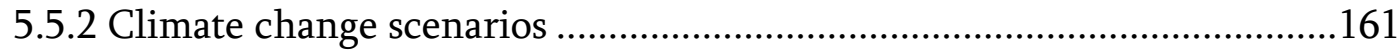

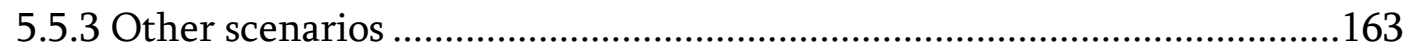

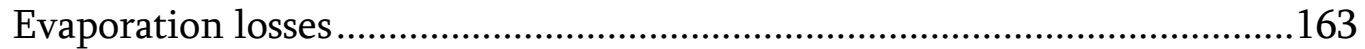

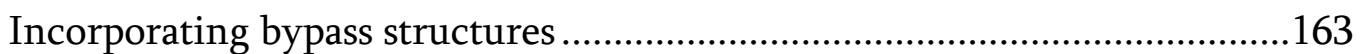

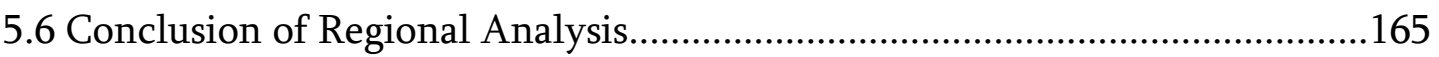

\section{Chapter 6: Discussion of Results}

6.1 Research findings in light of existing knowledge ........................................169

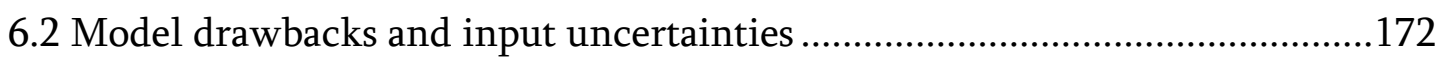

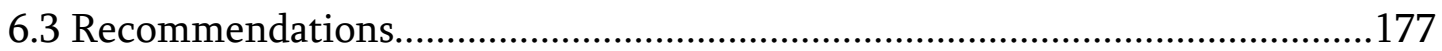

\section{Chapter 7: Conclusion}

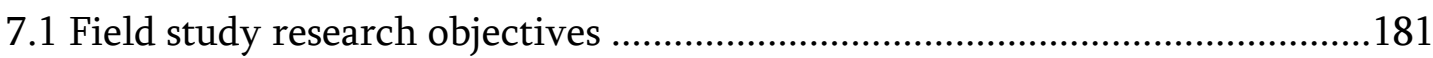

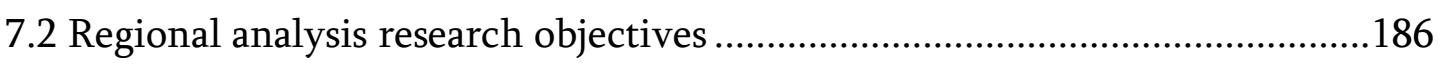

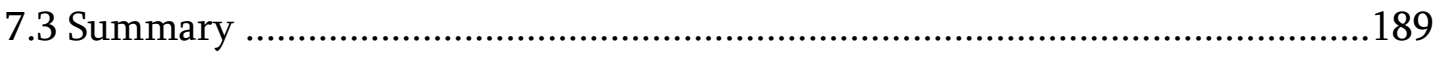

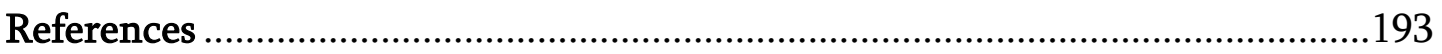




\section{Introduction}

\subsection{Small dams}

Small dams have been constructed in many countries for numerous uses including hydroelectric generation, flood control, and water supply. In New Zealand, most small dams are used for agricultural purposes, primarily as storage reservoirs for livestock use or irrigation during dry periods. The main focus of this study is to determine how small water supply dams interrupt the natural regime of streamflow and sediment transfer. Impacts on water quality and channel morphology are also investigated.

Numbers of small dams worldwide have been estimated at several million (Verstraeten and Poesen, 2000; Sahagian, 2000), and estimates of reservoirs $<60 \mathrm{ML}$ in volume in the United States alone has been placed at 2.5 million (USDA, 1981). Sahagian (2000) additionally suggests that the cumulative volume of small reservoirs may approach known volumes for large reservoirs. A further estimation places global farm pond coverage at $77,000 \mathrm{~km}^{2}$, which is approximately $0.05 \%$ of the Earth's land surface (Downing et al., 2006). No record exists of the exact number of small dams in New Zealand as regional councils do not require consents for their construction. However, two regional councils have investigated small pond numbers, with Auckland Regional Council reporting 4500 small constructed ponds in their region and Northland Regional Council estimating 2000 small constructed ponds in their region (McKerchar et al., 2005). With fifteen regional councils in New Zealand, small dams could easily number in the tens of thousands.

Annual construction of small reservoirs continues to increase globally; in some parts of the United States there is a 1-3\% increase in the number of new ponds every year (Smith et al., 2002). In more seasonally water-stressed regions, ponds are being constructed at much higher rates, with annual additions of up to $60 \%$ 
reported in the dry agricultural areas of India (Downing et al., 2006). These rates of pond construction will likely continue in the future with higher water demands resulting from increasing populations, lifestyle changes, land intensification, and expanded water supply systems.

The overall increase in water demand, accompanied by climate change predictions, has resulted in global water scarcity issues (McCully, 1996; Bates et al., 2008). It has been suggested that 1.8 billion people (23\% of the world's projected population) will be living in areas with absolute water scarcity by 2025 , with almost 6 billion people (75\% of the world's projected population) living under conditions of water stress (FAO, 2007). One response to the issue of water supply and security has been to build more water storage structures (e.g. dams, tanks, reservoirs) to be filled in times of surplus and used in times of shortage (e.g. Van Dijk et al., 2006). Small dams are suggested as a less damaging alternative to large dams (Hoover, 2001), and even with the changing views of society and industry towards the more efficient use of existing water supplies, it is likely that construction of these small dams will continue.

\subsection{Impacts of small dams}

While the environmental effects of small dams have not been studied extensively, there are many excellent papers providing overviews of the effects of large dams (e.g. Williams and Wolman, 1984; Rosenberg et al., 2000; World Commission on Dams, 2000). These studies have shown that large dams alter natural streamflow, sediment transfer, and river morphology, while also affecting instream and riparian habitat. Large reservoirs also release greenhouse gases $\left(\mathrm{CO}_{2}\right.$, $\mathrm{CH}_{4}$ ) from flooded and decomposing organic matter (St. Louis et al., 2000). Issues including social and economic impacts on local residents have also been reported (Goldsmith and Hildyard, 1984). Graf (1999) concluded that in the continental USA, the fragmentation of streams by large dams and the resulting change to 
stream discharge is likely several times greater than hydrological impacts predicted by climate change.

Research into the effects of small dams has not been as thorough and direct field studies are few in number. As concluded by Lowe et al. (2005: 14), "there is a real dearth of information on the expected range and variation of even the most basic farm dam characteristics." Small dams are generally assumed to have little to no impact on the larger system because they do not have large reservoirs or dampen the hydrologic regime to the same extent as large dams. Graf (1999) completed a census of dams in the United States but did not include small dams as "their aggregate effect is likely to be small except in highly localized contexts" (Graf, 1999: 1305). However, it is likely that the cumulative impact of many small dams will modify natural runoff patterns and may have a dramatic impact on the stream system (Finlayson et al., 2008).

Previous research has largely focused on modelling the effect of small dams on streamflow volumes, although there have been a few field studies investigating effects on water quality and sediment transfer. These studies are reviewed in detail in Chapter 2. Research on the impacts of small dams on ecological and societal factors is reviewed as a related issue, but does not form a major focus of the present research. The impacts of small dams and their cumulative influence at the larger catchment scale on streamflow, water quality, sediment transfer, and channel morphology form the subject of this study.

\subsection{Aims of Study}

As discussed previously, the environmental impact of small farm dams has not been studied extensively, particularly in New Zealand. With issues of water security coming to the fore as a result of agricultural intensification and drier climate predictions in some areas, small farm dam construction will likely continue. With this background in mind, the aims of the present research are to: 
1. Investigate the impact of small farm dams on streamflow, water quality, downstream transfers of sediment, and channel morphology;

2. Examine the cumulative effect caused by multiple dams within a catchment;

3. Predict the impact of farm dams and continued farm dam construction under a range of development and climate change scenarios from the catchment to regional scale; and

4. Suggest water management options for regional councils in New Zealand based on field and modelled research results.

These aims are addressed in two parts: through a field-based paired catchment study; and with a modelling application at the broader regional scale. It is envisaged that this work will ultimately have implications for water management and policy in New Zealand.

\subsubsection{Field-based study objectives}

The field-based study focuses on a comparison of flow characteristics, water quality, sediment transfer, and channel morphology between a regulated stream (flow regulated by three small dams) and an unregulated stream in the Tukipo River catchment, Hawke's Bay, New Zealand. Comparisons are made between the two streams and also between upstream and downstream reaches on the regulated stream. Observed changes between the two systems are quantified and used to inform the modelling aspect of the study. Specific questions to be addressed within the field-based component include:

1. How does regulation by small dams affect the timing and volume of flow reaching the catchment outlet?

2. How do changes to the flow regime caused by small farm dams affect sediment transfer and channel morphology? 
3. Are there significant water quality differences between the regulated and unregulated streams? How does water quality change within the ponds over time?

4. How are these changes affected by having multiple dams on the same stream?

\subsubsection{Modelling objectives}

Using the results of the field-based study to inform model choice and parameter estimation, two off-the-shelf hydrologic models which incorporate farm dam storages are used to model flow in the Tukipo River catchment and the larger Tukituki River catchment. Questions to be addressed include:

1. How does the current distribution of farm ponds affect streamflow volumes?

2. How would future scenarios of continued land intensification and climate change affect catchment streamflow volumes?

3. Can guidance be provided on the appropriate model structure for assessment of farm dam impacts at the catchment scale?

\subsection{Structure of Thesis}

Chapter 2 focuses on previous studies on the environmental effects of small dams and on current water use and future water needs in New Zealand. This is done with a view to providing a thorough background to the current research. Details of the study sites for the field-based and modelling study follow in Chapter 3 . Methodology and results of the paired catchment field study are covered in Chapter 4, and Chapter 5 covers the methodology and results for the modelling component of the research. Chapter 6 contains a discussion of the main findings of the study in light of previous small dam research, limitations to these results, and implications for water management in the study area. Research conclusions are summarised in Chapter 7. 


\subsubsection{Terminology}

In this study, 'small dams' will refer to dams that are less than $4 \mathrm{~m}$ in height, with a reservoir of no more than $3 \mathrm{~m}$ depth, or which hold no more than $20,000 \mathrm{~m}^{3}$ (20 ML) of water. These dimensions are based on the lower limit of dams which require registration under the New Zealand Building Act (2004). This definition will be followed generally, as there are some dams in the catchments under study that are slightly larger than these dimensions. The terms 'regulated' and 'regulation' will be used when discussing streams that have dams placed on them, resulting in a change to the natural flow regime. This is not to be confused with the regulation provided by large dams, where flow is controlled through physically manipulated releases. Small reservoirs created by dams that are built across stream channels (whether perennial or intermittent streams) will be referred to as 'onstream', while those constructed away from stream channels and filled by seasonal runoff or pumping from nearby streams will be referred to as 'offstream'. The terms 'pond' and 'reservoir' will be used interchangeably, referring to water that is held behind onstream dams as well as water held in offstream storages. In New Zealand, water from small onstream dams is typically released through a culvert placed near the top of the dam, meaning that reservoir outflow occurs only when this high level is reached. Other designs do exist to allow outflow at low reservoir levels, including bypass structures which divert streamwater around the dam during periods of low flow. These bypass structures, however, are not commonly used on small dams in New Zealand. 


\section{Background to Study}

\subsection{Impacts of small dams}

Dams are built for many uses, including generation of hydroelectricity, flood control, and/or water supply for irrigation or domestic needs. The size of dam and volume of water stored varies greatly, from large dams which can be hundreds of metres high and impound upwards of $180 \mathrm{~km}^{3}\left(180 \times 10^{6} \mathrm{ML}\right)$ of water, to small run-of-river dams which regulate flow but have no water storage capacity. For the purpose of the current research, the definition of a small dam will be based on that of the New Zealand Building Act (2004): less than $4 \mathrm{~m}$ in height, with a reservoir of no more than $3 \mathrm{~m}$ depth, or which holds no more than 20,000 $\mathrm{m}^{3}$ (20 ML) of water. Because this definition is arbitrary and physical effects of small dams are not necessarily limited by these dimensions, reviews of previous research and small dam inventories may include dams of a slightly larger size. In these instances the larger size will be noted.

Compared to studies on large dams, research on the effects of small dams is limited and is of a more specific nature, with studies undertaken mainly as a response to a particular engineering problem or environmental question. The bulk of small dam field research to date has been ecologically-based, focusing on the disconnection of streams and the subsequent change to downstream (and in some cases upstream) water quality and habitat (e.g. O'Connor, 2001; Saila et al., 2005; Anderson et al., 2006). Engineering studies by the US Geological Survey in the 1960s were conducted to determine seepage and evaporative losses for the purpose of constructing more efficient storage reservoirs in the arid regions of the USA. Recent research on small dam impact has primarily been model-based, with small dam storages factored into hydrologic models to determine impacts on catchment streamflow. The majority of these modelled studies have been completed in arid regions where widespread small dam construction has 
contributed to a significant impact on the hydrologic system. Most studies aim to provide water managers with more effective tools for water allocation in order to improve management decisions.

The following review of research to date will, where possible, be limited to small dams as they are the focus of the current study. However, in instances where direct small dam research has not been completed or where supporting studies are required, studies on large dams or on small structures such as weirs will be summarised and findings projected to estimate the potential effects of small dams. Compared to small dams, weirs have a more complex influence on the stream system. At stream levels higher than the weir crest, water is uninterrupted and flows freely downstream. At lower stream levels, water is impounded by the weir, typically at shallower depths as compared to water impounded by small dams.

\subsubsection{Flow regime}

A stream's flow regime influences channel morphology, sediment transfer, and water quality, as well as ecological processes of both the instream and riparian zone. The assessment of flow regime is therefore a key factor in determining the effects of small dams. Findings from small dam studies are varied and are influenced by local catchment runoff characteristics, volume of water stored within ponds, and volume of water extracted. However, studies generally show a decrease in annual runoff volume, a decrease in peak and low flow discharges, an increase in the duration and frequency of low flows, and a decrease in the variability of flow as compared to pre-dam or non-regulated flow regimes (e.g. Frickel, 1972; Srikanthan and Neil, 1989; Tarboton and Schultze, 1991). Shifts in the timing of flow events may also create flow at times that were previously dry (e.g. Kennon, 1966).

The effect of small dams on annual runoff volumes has been estimated using direct field measurements, water balance analyses, and/or other modelling 
techniques, with most studies to date using a modelling approach. Modelled impacts of small dams on streamflow volumes generally involve adding a storage component to an existing rainfall-runoff model. The simplest method used is a "fill and spill" scenario, with farm dams acting as an additional store in the catchment (e.g. as shown in the alteration of the rainfall-runoff model IHACRES by Schreider et al., 2002). Spatially distributed models characterise the location and storage volume of dams within the catchment and simulate routing of flow from the ponds to the catchment outlet. Models used specifically for estimation of flow from farm dams will be discussed in greater detail in Chapter 5. General findings on the impact of farm dams on flow (both modelled and observed) are presented here.

Regulation will decrease annual runoff volume due to additional seepage and evaporative losses. In Australia, evaporative losses from stored water can be as high as 70\% (Neal et al., 2000) and on the Ruataniwha Plains area of New Zealand, it has been estimated that seepage and evaporative losses can be $50 \%$ of total pond storage over a summer season (McGuinness, 1984). Water extraction from the ponds will add another component to overall runoff loss. Although one small dam will not have a large effect on the runoff regime, the cumulative effect of many dams in a catchment may have a significant impact on downstream flow (Finlayson et al., 2008).

Results of both field-based and modelled studies have indicated that farm dams can reduce catchment outflow significantly, although volumes vary based on specific catchment conditions. A summary of measured and modelled streamflow reductions as a result of small dam construction is shown in Table 2.1. Direct comparisons amongst the studies are difficult to make because data and results are not presented consistently across all studies. With this in mind, studies show streamflow volume reductions ranging from negligible to $40 \%$ of mean or median annual flow (under average catchment climate conditions). With regards to Table 2.1, it should be noted that most small dam studies have been undertaken in arid 
Table 2.1: Summary of previous research on the influence of small dams on catchment streamflow, organised regionally (USA, Australia, other). Missing information in the table indicates unavailable data.

\begin{tabular}{|c|c|c|c|c|c|c|}
\hline Location & $\begin{array}{l}\text { Catch. } \\
\text { size }\end{array}$ & $\begin{array}{l}\text { Total pond } \\
\text { numbers }\end{array}$ & $\begin{array}{l}\text { Total } \\
\text { pond } \\
\text { volume }\end{array}$ & $\begin{array}{l}\text { Reduction of } \\
\text { flow }{ }^{1}\end{array}$ & Method & Source \\
\hline SD, USA & $\begin{array}{l}49 \text { sites, } \\
\text { each } 23 \\
\mathrm{~km}^{2}\end{array}$ & $\begin{array}{l}466 \text { stock } \\
\text { ponds }\end{array}$ & $3000 \mathrm{ML}$ & $\begin{array}{l}11-33 \% \text { mean } \\
\text { annual, dry years }\end{array}$ & $\begin{array}{l}\text { water } \\
\text { balance }\end{array}$ & Culler, 1961 \\
\hline $\begin{array}{l}\text { OK, } \\
\text { USA }\end{array}$ & $220 \mathrm{~km}^{2}$ & $\begin{array}{l}22 \text { flood } \\
\text { retarding } \\
\text { ponds }\end{array}$ & $\begin{array}{l}25,000 \\
\text { ML }\end{array}$ & $\begin{array}{l}20 \% \text { mean } \\
\text { annual, wet years }\end{array}$ & $\begin{array}{l}\text { water } \\
\text { balance }\end{array}$ & $\begin{array}{l}\text { Kennon, } \\
1966\end{array}$ \\
\hline $\begin{array}{l}\text { MT, } \\
\text { USA }\end{array}$ & $\begin{array}{l}1400 \\
\mathrm{~km}^{2}\end{array}$ & 190 & $\begin{array}{l}59,000 \\
\text { ML }\end{array}$ & $\begin{array}{l}18 \% \text { mean } \\
\text { annual; } \\
45 \% \text { peak annual }\end{array}$ & $\begin{array}{l}\text { water } \\
\text { balance }\end{array}$ & $\begin{array}{l}\text { Frickel, } \\
1972\end{array}$ \\
\hline $\begin{array}{l}\text { CO, } \\
\text { USA }\end{array}$ & & $\begin{array}{l}\text { multiple } \\
\text { dams and } \\
\text { diversions }\end{array}$ & $\begin{array}{l}1.2 \times 10^{6} \\
\mathrm{ML}\end{array}$ & $\begin{array}{l}\text { 6-38\% mean } \\
\text { annual; } \\
\text { 29-38\% peak } \\
\text { annual }\end{array}$ & $\begin{array}{l}\text { pre- to post- } \\
\text { land use } \\
\text { change }\end{array}$ & $\begin{array}{l}\text { Van Steeter } \\
\text { and Pitlick, } \\
1998\end{array}$ \\
\hline SA, AUS & & & & $\begin{array}{l}50 \% \text {, dry years; } \\
\text { negligible, wet } \\
\text { years }\end{array}$ & & $\begin{array}{l}\text { Ockenden, } \\
\text { Kotwicki, } \\
1982\end{array}$ \\
\hline $\begin{array}{l}\text { VIC, } \\
\text { AUS }\end{array}$ & $210 \mathrm{~km}^{2}$ & 637 & $\begin{array}{l}11,800 \\
\mathrm{ML}\end{array}$ & $\begin{array}{l}7 \% \text { mean annual; } \\
50 \% \text { mean } \\
\text { annual, dry years }\end{array}$ & $\begin{array}{l}\text { model; } \\
\text { HYDRO- } \\
\text { LOG }\end{array}$ & $\begin{array}{l}\text { Gutteridge } \\
\text { Haskins \& } \\
\text { Davey, } 1987\end{array}$ \\
\hline $\begin{array}{l}\text { NSW, } \\
\text { AUS }\end{array}$ & $\begin{array}{l}10 \mathrm{~km}^{2} \\
\text { and } \\
4 \mathrm{~km}^{2}\end{array}$ & $\begin{array}{l}780 \text { and } \\
66\end{array}$ & & $\begin{array}{l}0.3-8 \% \text { mean } \\
\text { annual (higher in } \\
\text { dry years) }\end{array}$ & $\begin{array}{l}\text { water } \\
\text { balance } \\
\text { model }\end{array}$ & $\begin{array}{l}\text { Srikanthan } \\
\text { and Neil, } \\
1989\end{array}$ \\
\hline SA, AUS & & & & $\begin{array}{l}44 \% \text { dry years; } \\
13 \% \text { wet years }\end{array}$ & & $\begin{array}{l}\text { Cresswell, } \\
1991\end{array}$ \\
\hline SA, AUS & & & & $\begin{array}{l}10 \% \text { mean } \\
\text { annual; } \\
35 \% \text { dry years; } \\
5 \% \text { wet years }\end{array}$ & & Good, 1992 \\
\hline SA, AUS & $238 \mathrm{~km}^{2}$ & & $\begin{array}{l}>1500 \\
\mathrm{ML}\end{array}$ & $\begin{array}{l}0.6 \% \text { mean } \\
\text { annual }\end{array}$ & $\begin{array}{l}\text { model; } \\
\text { TEDI }\end{array}$ & $\begin{array}{l}\text { Nathan et } \\
\text { al., } 2000\end{array}$ \\
\hline $\begin{array}{l}\text { VIC, } \\
\text { AUS }\end{array}$ & $\begin{array}{l}34 \mathrm{~km}^{2} \\
\text { and } \\
311 \mathrm{~km}^{2}\end{array}$ & & $\begin{array}{l}96 \mathrm{ML} \\
\text { and } \\
740 \mathrm{ML}\end{array}$ & $\begin{array}{l}1.5-15 \% \mathrm{Q}_{50} \\
11-15 \% \mathrm{Q}_{90} \\
2-4 \% \mathrm{Q}_{10}\end{array}$ & $\begin{array}{l}\text { model; } \\
\text { TEDI }\end{array}$ & $\begin{array}{l}\text { Melbourne } \\
\text { Water, } 2000\end{array}$ \\
\hline $\begin{array}{l}\text { VIC, } \\
\text { AUS }\end{array}$ & $\begin{array}{l}46 \text { to } 322 \\
\mathrm{~km}^{2}(5 \\
\text { basins })\end{array}$ & & $\begin{array}{l}26 \mathrm{ML} \text { to } \\
678 \mathrm{ML}\end{array}$ & $\begin{array}{l}0.6-4.4 \% \text { mean } \\
\text { annual; } \\
1.9-2.5 \% Q_{50} ; \\
0.3-11 \% Q_{90}\end{array}$ & $\begin{array}{l}\text { model; } \\
\text { TEDI }\end{array}$ & $\begin{array}{l}\text { Neal et al., } \\
2000\end{array}$ \\
\hline $\begin{array}{l}\text { VIC, } \\
\text { AUS }\end{array}$ & $76 \mathrm{~km}^{2}$ & & $1729 \mathrm{ML}$ & $\begin{array}{l}21 \% \mathrm{Q}_{50} \\
27 \% \mathrm{Q}_{90} \\
16 \% \mathrm{Q}_{10}\end{array}$ & $\begin{array}{l}\text { model; } \\
\text { TEDI }\end{array}$ & $\begin{array}{l}\text { Melbourne } \\
\text { Water, } 2002\end{array}$ \\
\hline SA, AUS & $388 \mathrm{~km}^{2}$ & 1402 & $5022 \mathrm{ML}$ & $2 \%$ mean annual & $\begin{array}{l}\text { model; } \\
\text { TEDI }\end{array}$ & $\begin{array}{l}\text { Neal et al., } \\
2002\end{array}$ \\
\hline SA, AUS & $240 \mathrm{~km}^{2}$ & 640 & $2400 \mathrm{ML}$ & $\begin{array}{l}18 \% \text { mean } \\
\text { annual; } \\
24 \% \mathrm{Q}_{50}\end{array}$ & $\begin{array}{l}\text { model; } \\
\text { Watercress }\end{array}$ & $\begin{array}{l}\text { Savadamu- } \\
\text { thu, } 2002\end{array}$ \\
\hline
\end{tabular}


Table 2.1 (con't)

\begin{tabular}{|c|c|c|c|c|c|c|}
\hline Location & $\begin{array}{l}\text { Catch. } \\
\text { size }\end{array}$ & $\begin{array}{l}\text { Total pond } \\
\text { numbers }\end{array}$ & $\begin{array}{l}\text { Total } \\
\text { pond } \\
\text { volume }\end{array}$ & $\begin{array}{l}\text { Reduction of } \\
\text { flow }^{1}\end{array}$ & Method & Source \\
\hline $\begin{array}{l}\text { VIC, } \\
\text { AUS }\end{array}$ & $757 \mathrm{~km}^{2}$ & & & $\begin{array}{l}\text { up to } 12 \% \mathrm{Q}_{50} \\
11 \% \mathrm{Q}_{90}\end{array}$ & $\begin{array}{l}\text { model; } \\
\text { TEDI }\end{array}$ & $\begin{array}{l}\text { National } \\
\text { River } \\
\text { Health, } \\
2002 \\
\end{array}$ \\
\hline SA, AUS & $560 \mathrm{~km}^{2}$ & 2700 & $8500 \mathrm{ML}$ & $\begin{array}{l}1-20 \% \mathrm{Q}_{50} ; \\
3-39 \% \text {, dry years; } \\
0-10 \% \text {, wet years }\end{array}$ & $\begin{array}{l}\text { model; } \\
\text { Watercress }\end{array}$ & Teoh, 2002 \\
\hline SA, AUS & $193 \mathrm{~km}^{2}$ & 1246 & 5822ML & $\begin{array}{l}\text { 10\% } \mathrm{Q}_{50} ; \\
72 \% \text { Q } 50 \text { summer; } \\
7 \% \text { Q } 5 \text { winter }\end{array}$ & $\begin{array}{l}\text { model; } \\
\text { Watercress }\end{array}$ & $\begin{array}{l}\text { Savadamu- } \\
\text { thu, } 2003\end{array}$ \\
\hline $\begin{array}{l}\text { VIC, } \\
\text { AUS } \\
\end{array}$ & $\begin{array}{l}1172 \\
\mathrm{~km}^{2}\end{array}$ & $>4000$ & $\begin{array}{l}14,400 \\
\text { ML }\end{array}$ & $\begin{array}{l}15 \% \text { mean } \\
\text { annual }\end{array}$ & $\begin{array}{l}\text { model; } \\
\text { TEDI }\end{array}$ & SKM, 2004 \\
\hline SA, AUS & $388 \mathrm{~km}^{2}$ & 676 & $884 \mathrm{~mL}$ & $\begin{array}{l}<10 \% \mathrm{Q}_{50} ; \\
>20 \% \text { dry years } \\
\text { (some reaches } \\
\text { much higher) }\end{array}$ & $\begin{array}{l}\text { arithmetic } \\
\text { model }\end{array}$ & $\begin{array}{l}\text { McMurray, } \\
2006\end{array}$ \\
\hline $\begin{array}{l}\text { VIC, } \\
\text { AUS }\end{array}$ & $\begin{array}{l}4000 \\
\mathrm{~km}^{2}\end{array}$ & 12,956 & $\begin{array}{l}39,884 \\
\text { ML }\end{array}$ & $\begin{array}{l}10 \% \text { mean } \\
\text { annual; } 6-40 \% \\
\text { subcatchments }\end{array}$ & $\begin{array}{l}\text { model; } \\
\text { CHEAT }\end{array}$ & SKM, 2008 \\
\hline $\begin{array}{l}\text { Bots- } \\
\text { wana }\end{array}$ & & $\begin{array}{l}320 \text { small; } \\
1 \text { large }\end{array}$ & $\begin{array}{l}29,700 \\
M L\end{array}$ & $\begin{array}{l}0.2 \text { to } 25 \% \text { mean } \\
\text { annual }\end{array}$ & $\begin{array}{l}\text { water } \\
\text { balance } \\
\text { model }\end{array}$ & Meigh, 1995 \\
\hline Brazil & $\begin{array}{l}2000 \\
\mathrm{~km}^{2}\end{array}$ & $\begin{array}{l}\text { several } \\
\text { small and } \\
\text { medium }\end{array}$ & $\begin{array}{l}200,000 \\
\text { ML }\end{array}$ & $\begin{array}{l}10 \% \text { mean } \\
\text { annual; } \\
25 \% \text { dry years }\end{array}$ & $\begin{array}{l}\text { arithmetic } \\
\text { model }\end{array}$ & $\begin{array}{l}\text { Szesztay, } \\
1973\end{array}$ \\
\hline Brazil & $\begin{array}{l}70,000 \\
\mathrm{~km}^{2}\end{array}$ & $\begin{array}{l}\text { several } \\
\text { thousand } \\
\text { small; 300- } \\
500 \text { med; } \\
15 \text { large }\end{array}$ & $\begin{array}{l}5 \times 10^{6} \\
M L\end{array}$ & $\begin{array}{l}24 \% \text { mean } \\
\text { annual; } \\
36 \% \text { Q50; } \\
27-47 \% \text { dry; } \\
17 \% \text { wet years }\end{array}$ & $\begin{array}{l}\text { arithmetic } \\
\text { model }\end{array}$ & 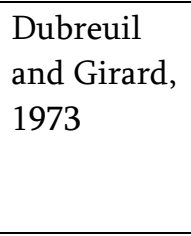 \\
\hline NZ & & $\begin{array}{l}>2000 \\
\text { large and } \\
\text { small }\end{array}$ & & $\begin{array}{l}\text { up to } 25 \% \text { mean } \\
\text { annual }\end{array}$ & $\begin{array}{l}\text { arithmetic } \\
\text { model }\end{array}$ & $\begin{array}{l}\text { McKerchar } \\
\text { et al., } 2005\end{array}$ \\
\hline $\begin{array}{l}\text { South } \\
\text { Africa }\end{array}$ & $912 \mathrm{~km}^{2}$ & 459 & & $\begin{array}{l}\text { 6\% Q50 (range } \\
3-33 \% \text { ) }\end{array}$ & $\begin{array}{l}\text { ACRU } \\
\text { model }\end{array}$ & $\begin{array}{l}\text { Tarboton } \\
\text { and Schulze, } \\
1991\end{array}$ \\
\hline $\begin{array}{l}\text { South } \\
\text { Africa }\end{array}$ & 2 regions & $\begin{array}{l}14,257 \text { and } \\
10,040 \\
\text { water } \\
\text { bodies }\end{array}$ & & $\begin{array}{l}\text { significant } \\
\text { decreases in } \\
\text { mean annual, } Q_{10} \\
\text { and } Q_{90}\end{array}$ & $\begin{array}{l}\text { statistical } \\
\text { analysis of } \\
\text { small dam } \\
\text { densities } \\
\end{array}$ & $\begin{array}{l}\text { Mantel et } \\
\text { al., } 2010\end{array}$ \\
\hline
\end{tabular}

${ }^{1}$ Reduction of flow derived from flow duration curves: $\mathrm{Q}_{50}=$ flow exceeded $50 \%$ of the time (median flow), $\mathrm{Q}_{10}=$ flow exceeded $10 \%$ of the time (high flows), and $\mathrm{Q}_{90}=$ flow exceeded $90 \%$ of the time (low flows). 
or semi-arid regions, which will likely reveal a bias towards greater losses to evaporation and therefore to higher losses overall. It is also shown in Table 2.1 that the majority of studies from Australia are based on the same model, TEDI (Tools for Estimating Farm Dam Impacts; SKM, 2002). Although studies have verified the applicability of this model (e.g. Nathan et al., 2005), any biases inherent in the modelling structure will have an effect on modelled output and may skew these summary results.

Climatic variability and seasonal weather patterns have an additional influence on regulated flow regimes. Small dams have an enhanced influence on flow during dry seasons or in drier than average years. Savadamuthu (2003) found a maximum reduction in streamflow of $72 \%$ for the dry summer season (compared to a $7 \%$ reduction in the winter) in the Upper Finniss catchment of South Australia. Stephens (1964) found the influence of farm dams on runoff and yield in the wetter parts of Texas to be of little significance, while the effects were substantial in dry areas of Texas, especially in drought years. McMurray (2006) had similar findings for a catchment under modelled wet and dry year scenarios: high environmental stress conditions (where streamflow volumes had decreased by $20 \%$ or more) were found for most catchment streams in a dry-year scenario, while median and wet-year scenarios were less likely to cause stress. Table 2.2 shows the ranges and average flow reductions for wet and dry year (and seasonal) scenarios as summarised from the studies in Table 2.1. In all cases, there is an increase in flow reduction under dry conditions as compared to both average and wet years. Therefore, it is during the dry season and/or dry years that the downstream impact of small dams on flow is most significant.

Along with the overall decrease in annual runoff volumes, farm dams affect the variability of flow by decreasing peak flows and shifting the timing and volume of both peak flows and low flows (Tarboton and Schultze, 1991). Frickel (1972) measured a $45 \%$ reduction in peak discharge in a catchment in Montana wherein 
Table 2.2: Summary of study results on the effect of farm dams on streamflow under a range of seasonal or annual changes in precipitation.

\begin{tabular}{|l|l|l|l|}
\hline \multicolumn{2}{|l|}{ Reduction in mean or median streamflow (\%) } & \\
\hline Annual & Wet conditions & Dry conditions & Source \\
\hline \hline 10 (mean) & & 25 & Szesztay, 1973 \\
\hline 24 (mean) & 17 & $27-47$ & Dubreuil and Girard, 1973 \\
\hline & 0 & 50 & $\begin{array}{l}\text { Ockenden and Kotwicki, } \\
1982\end{array}$ \\
\hline 7 (mean) & & 50 & $\begin{array}{l}\text { Gutteridge Haskins \& Davey, } \\
1987\end{array}$ \\
\hline & 13 & 44 & Cresswell, 1991 \\
\hline 10 (mean) & 5 & 35 & Good, 1992 \\
\hline $1-20$ (median) & $0-10$ & $3-39$ & Teoh, 2002 \\
\hline 10 (median) & 7 & 72 & Savadamuthu, 20031 \\
\hline$<10$ (median) & & $>20$ & McMurray, 2006 \\
\hline
\end{tabular}

${ }^{1}$ All studies show annual figures except for Savadamuthu (2003) which is based on seasonal measurements (wet $=$ winter; dry $=$ summer).

$75 \%$ of the total area of the catchment was controlled by reservoirs. A $16 \%$ decrease of peak flow in the Stringybark catchment, Victoria, Australia was modelled using TEDI (Melbourne Water, 2002). When individual streams within the catchment were modelled, reduction in peak flow was as high as $33 \%$. Other studies have also shown a decrease in peak flow (e.g. Van Steeter and Pitlick, 1998; Melbourne Water, 2000).

Unless a bypass structure exists to allow streamflow to bypass the dam when flow is below a certain volume, small farm ponds store all runoff contributions from upstream until the pond is full and can once again contribute to downstream flow. The pond's water balance is determined by measuring inputs from upstream flow and outputs from seepage, evaporation, and water takes. The drawdown of pond water will be enhanced during the growing season when pumping for irrigation begins (Savadamuthu, 2002). If times of highest water demand coincide with dry periods, as is often the case, this effect will be exacerbated. The combined effects create lower flows and longer periods of low flow (Srikanthan and Neil, 1989) and may even stop downstream flow completely (Beavis and Howden, 1996). Neal et al. (2000) found the presence of farm dams increased the 
"frequency, duration and variability of low flow spells" (Neal et al., 2000: 4). As well, farm dams will delay downstream flow at the beginning of the wet season when the ponds are slowly filling (McMurray, 2006).

Modelled studies using TEDI have shown decreases in both $\mathrm{Q}_{10}$ (flow exceeded $10 \%$ of the time; i.e. peak flow) and Q90 (flow exceeded $90 \%$ of the time; i.e. low flow) (Melbourne Water, 2000, 2002; Neal et al., 2000; National River Health, 2002). In most cases, the relative decrease in low flow is greater than the decrease to high flow (e.g. 16\% decrease in $\mathrm{Q}_{10}, 27 \%$ decrease in $\mathrm{Q}_{90}$; Melbourne Water, 2002). This is likely a result of larger precipitation events occurring during the wetter winter season. In these instances, peak flows occur when the ponds are full, resulting in a lower (to negligible) effect of the ponds on high flow (Neal et al., 2000). A difference would likely be found in areas where high precipitation events occur throughout the entire year.

A shift in the timing of flow may lead to flow occurring during periods which were previously dry. There have been indications that flow may increase during previously dry periods because of raised water table levels and shallow groundwater inputs to the stream channel (e.g. Kennon, 1966). This is likely related to soil hydraulic conductivities and the slow seepage of water from the reservoir to surrounding zones, which may also increase groundwater recharge in some cases (Smith et al., 2002). In studies on medium-sized reservoirs in semiarid regions of the USA, the raising of water table levels in the vicinity of reservoirs was noted, which eventually led to outflow streams shifting from ephemeral to perennial (Kennon, 1966; Frickel, 1972). Palmer and O’Keefe (1990) noted the continuation of streamflow directly downstream of dams as a result of seepage, even after reservoir levels fell and reservoir outflow did not contribute flow to the stream. All studies reporting this phenomenon were undertaken in arid or semi-arid climates where streamflow is ephemeral or intermittent; however, it is unlikely that this is solely an arid zone phenomenon. 
The water table rise adjacent to ponds and increase in groundwater recharge is balanced by instances of lowered water table levels and decreased groundwater recharge further downstream (Savadamuthu, 2002). These downstream changes are linked to the overall decrease in regulated flow volumes. However, the relationship is not only related to distance from the pond. Al-Nuaimi and Murad (2007) studied water table fluctuations downstream of dams in the United Arab Emirates. These dams are primarily built to allow the slow infiltration of rainfall to recharge underlying aquifers. Their findings show an increase in water table levels in some years, but a lowered effect in other years when sedimentation of the pond limits near-pond infiltration and seepage. Therefore, the rate of pond sedimentation, generally related to the age of the pond, may have an added effect on water table levels in areas surrounding the pond.

The influence of farm dam size and placement within the catchment has also been studied. Using a model developed for catchments in Botswana, Meigh (1995) found that a small number of large dams had a lower impact on downstream flow volumes as compared to a large number of small dams with the same total capacity. This was explained by the fact that total evaporation losses would be lower with a greater number of large dams, which tend to be built with a more efficient shape (Meigh, 1995). Further model predictions from the study showed a greater decrease in mean annual flow when the dams were placed further downstream in the catchment. Downstream dams would have larger upstream contributions, resulting in a more frequent fill and higher total losses to evaporation. The study concluded that catchment flow volumes would be impacted less if small dams were preferentially placed in the upper parts of the catchment, with fewer large dams preferred over numerous small dams. However, this last recommendation came with the caveat that it is made based solely on water volumes and not on other environmental indicators (Meigh, 1995). This is an important distinction, as Bosch (2008) found that model predictions of downstream water quality showed greater improvements with a 
large number of small ponds rather than a small number of large ponds (of the same total volume).

\section{Summary of small dam effects on flow regime}

Research to date suggests there will be a reduction in runoff volume from catchments regulated by numerous small dams, particularly where reservoirs have high seepage, evaporative losses, and water takes. Declines in streamflow of up to $40 \%$ of annual volumes have been measured and modelled (SKM, 2008). Higher flow reductions have been found during dry seasons and/or dry years. Variability of flow will be altered through decreased peak flows and low flows. The timing of flow commencement at the beginning of the wet season may also be delayed depending on the specifics of the dam and whether or not bypass structures are included. In some cases, low flows have continued directly downstream of dams through previously dry periods as a result of higher water table levels adjacent to the reservoir. Continued field research in association with modelling will further refine our understanding of small dam impacts. However, specific knowledge of internal catchment processes, the magnitude of flow regime change, and the subsequent effect on associated systems (e.g. ecologic, morphologic) are still largely unknown, particularly in non-arid catchments such as those in New Zealand.

\subsubsection{Water quality}

The interruption of a flowing stream and the subsequent storage of water in a reservoir will affect water quality. Water quality is determined by a number of measures including nutrient and bacteria levels, $\mathrm{pH}$, dissolved oxygen (DO), temperature, and salinity. The actual change in quality will depend on the volume of water stored and its residence time within the reservoir, along with any constituent inputs to the reservoir (dependent on catchment land use, geology, etc). In some cases, reservoirs act as nutrient sinks to ameliorate downstream water quality (e.g. Bere, 2007). However, there are also studies 
which have found lowered water quality downstream of small dams (e.g. Maxted et al., 2005). Some reservoirs may even have both a positive and negative effect, as in the case where water storage within a reservoir leads to an increase in water quality through filtration effects, but then leads to increased algal growth downstream because of decreased flow (MFE, 2000). As the present research is focused on farm dams, nutrient dynamics specific to agricultural land use practices will first be reviewed, followed by research regarding water quality changes of both the pond and downstream reaches.

\section{Nutrient inputs from agricultural areas}

Nutrients reach the stream system through dissolved load inputs (from surface runoff or percolation of water through the soil) or by attachment to clay or siltsized soil colloids which are eroded and transported to the stream. Nutrient mobilisation will be heightened in areas where high rainfall volume is associated with bare or vulnerable soil, and/or areas of high fertiliser and manure application (Heathwaite et al., 2005). The main nutrient inputs studied in terms of agricultural production are nitrogen $(\mathrm{N})$ and phosphorus $(\mathrm{P})$, as these are generally the most limiting nutrients for plant growth (Hart et al., 2004). Nitrogen and phosphorus can negatively impact waterways (Newham and Drewry, 2006) and so are studied from an ecological perspective as well. When there are high concentrations of nutrients in water, this can lead to increased levels of biological productivity, which over time can cause eutrophication of the pond or stream and the growth of cyanobacteria (blue-green algae). Although eutrophication does occur naturally in ponds under conditions of slow sedimentation, the process can be sped up by anthropogenic activities (Lampert and Sommer, 2007).

Streams draining agricultural catchments have higher $\mathrm{N}$ and $\mathrm{P}$ inputs in comparison to natural areas (Collier et al., 1995; Langland et al., 2000). In a New Zealand study of low elevation catchments, dissolved $\mathrm{N}$ and $\mathrm{P}$ inputs from 
pastoral and urban catchments were 2 to 7 times higher than inputs from forested catchments (Larned et al., 2004). These results have been supported by other catchment land use studies in New Zealand, including Cooke and Cooper (1988), Quinn and Stroud (2002), and Elliott and Sorrel (2002), along with international studies (e.g. Cooke and Prepas, 1998). The 2007 Environment New Zealand report (MFE, 2007b) which summarises data from all rivers within the national monitoring network, also shows increased levels of $\mathrm{N}$ and $\mathrm{P}$ in pastoral catchments as compared to natural catchments. Similar trends were found for lake data, with $\mathrm{N}$ and $\mathrm{P}$ levels 4 to 6 times higher in lakes in pastoral catchments as compared to those in natural catchments. The national data also show that $\mathrm{N}$ and P levels are higher than ANZECC (Australia and New Zealand Environment and Conservation Council) guidelines for ecosystem protection in pastoral catchments, whereas nutrient levels are well below the recommended guidelines in natural catchments (MFE, 2007a).

In New Zealand, there has been an overall trend of increasing $\mathrm{N}$ and $\mathrm{P}$ levels within rivers over the past two decades. It has been suggested that the cause of this decline in water quality is "diffuse runoff associated with agricultural land use and land use intensification (increased stocking rates and increased fertiliser use)" (HBRC, 2006b). Land use intensification has primarily been through dairy, with a 24\% increase in national dairy numbers between 1996 and 2006 (MFE, 2007b). An increase in nitrogen fertiliser application on dairy farms was noted in the Waikato region of New Zealand (Brodnax, 2007). As well, livestock cause an increase in nutrient inputs both through their waste and through enhanced erosion of soil by trampling. In areas where stock is gathered, higher concentrations of manure and urine will result. This is a more significant issue with cattle in comparison to sheep because of the nature of their pasture grazing. Dairy cattle are most often stocked at higher rates and preferentially on lowland pastures, which increases $\mathrm{N}$ inputs and allows a shorter travel distance of nutrients to streams. Cooke and Prepas (1998) state that increased nutrient loads 
can occur if cattle have direct access to streams, resulting in substantive effects on downstream water quality. Wilcock et al. (2006) note that water quality in dairying catchments is influenced by the "extent of stock access to the stream network, discharges from dairy ponds and drains, as well as land-use intensity factors like fertiliser application rate and grazing intensity" (Wilcock et al., 2006: 135).

The removal of nutrients occurs in the stream through uptake by macrophytes, periphyton, and bacteria, along with sediment sorption and settling out of particulates (Elliott and Sorrell, 2002). Larger quantities of nutrients per unit of channel length are removed in small shallow streams (mean flow $<1 \mathrm{~m}^{3} / \mathrm{s}$ ) (McColl and Hughes, 1981) because of the higher benthic surface area to water/volume ratio (Alexander et al., 2002). Rates of removal have been modelled on the order of $20 \% / \mathrm{km}$ for nitrogen (compared to $0.1 \% / \mathrm{km}$ in larger streams) and 35\%/km for phosphorus (Alexander et al., 2002). However, in small catchments with shorter streams, less cumulative removal of nutrients will occur (Alexander et al., 2002). In New Zealand, many streams are short, and many firstorder streams are intermittent, suggesting that removal of nutrients by instream processes may not be as efficient.

\section{Small dam effects on water quality}

The study of reservoir water quality most commonly focuses on nutrients, dissolved oxygen, and water temperature, as these are the factors that can have a major impact on downstream ecosystem health if they become too degraded. Stream temperature is often studied in water quality investigations because of its impact on instream communities. In unregulated rivers with no local geothermal activity, stream temperatures slowly increase downstream (Hopkins, 1971; Grant, 1977). In regulated streams, temperature will change as water moves through a reservoir, with the greatest change to water temperature found in shallow reservoirs with long residence times. If nutrient and bacterial inputs to the 
reservoir are high and residence times are long, other water quality measures will also be degraded. In these instances, outflow from the reservoir is likely to be low in quality unless there is a frequent replenishment of fresh water to the pond (Hughes, 2008). Outflow water quality will also depend on where the outflow structure is located (i.e. top or bottom release) and whether or not the reservoir is stratified. Thermal stratification can occur seasonally and may contribute to depleted levels of oxygen in cold bottom lake layers (Boyd, 2000). However, it is unlikely that stratification in farm ponds occurs as they are generally too shallow (usually $<4 \mathrm{~m}$ depth) and winds would be sufficient to create suitable mixing of pond water.

There have been few water quality studies undertaken in, and downstream of, small constructed ponds. Only one has been completed in New Zealand (Maxted et al., 2005), measuring DO, stream temperature, and macroinvertebrate community changes downstream of six small onstream ponds in forest and pasture settings. The results revealed that ponds had poorer water quality in comparison to stream reaches, and that water quality decreased in a downstream direction. Rural ponds with large surface areas and long retention times had the most degraded conditions. The authors recommended that the construction of small onstream dams should not be encouraged and that those not currently in use should be decommissioned (Maxted et al., 2005). A study on 15 low-head dams (weirs) on the Fox River, Illinois found that DO and pH often failed to meet water quality standards in ponds and immediate upstream channel reaches, with degraded levels of water quality, habitat, and biotic communities in impounded reaches (Santucci et al., 2005). Although the structures in the study were weirs, they impounded flow to average depths of $<2.1 \mathrm{~m}$ (similar to farm ponds). The impounded water had a faster turnover time than expected for lakes (Santucci et al., 2005), which suggests that ponds with longer storage times might have even higher levels of water degradation. 
The influence of small dams on downstream water quality can be inferred through studies on small dam removals. There have been a large number of small dams removed in the United States in recent years. Dams are often removed when they reach their 100-year expected age limit because the cost of safety rehabilitation measures is too high for private owners or municipalities (Shuman, 1995). In other cases, dams are removed to enhance instream habitat and allow for fish passage. Five small dams on the Shasta River, California were removed after declining fish populations were linked to higher stream temperatures and lower DO levels downstream of the dams (Unkefer, 2008). Monitoring at one site has shown that temperature spikes have diminished since removal of the dam (Unkefer, 2009). An improvement in stream turbidity and water temperature levels was also found after a $2.2 \mathrm{~m}$ dam was removed from the Sandusky River in Ohio (Nechvatal and Granata, 2004).

In the case of small dams with top releases, mean daily water temperature in the summer has been found to increase in downstream reaches (Lessard and Hayes, 2003; Maxted et al., 2005). Lessard and Hayes (2003) studied stream temperatures downstream of small dams on ten streams in Michigan, finding a mean stream temperature increase of $2.7^{\circ} \mathrm{C}$, with no return to upstream temperatures even after 2 to $3 \mathrm{~km}$. Summer stream temperatures were elevated by 3.1 to $6.6^{\circ} \mathrm{C}$ for hundreds of metres downstream of six small dams in the Auckland region of New Zealand, with stream temperature recovering (i.e. cooling) slowly at a rate of $1^{\circ} \mathrm{C} / 100 \mathrm{~m}$ (Maxted et al., 2005). However, a study on 15 low-head dams (weirs) in Illinois found no significant change in the range of temperatures found between impounded and free-flowing river reaches (Santucci et al., 2005). This may be explained by the fact that the larger river in this study might have promoted better mixing, and the weirs would have provided shorter residence times within the impounded reaches. A similar result of no difference in stream temperature above and below low-head dams in Spain was found by MendozaLera et al. (2010). However, this study was completed during the autumn and 
winter high flow period when streams were connected and temperatures would be more constant throughout the system. Differences in stream temperature above and below the dams would likely be more pronounced during the summer months of lower streamflow levels.

Because few studies exist on the influence of farm ponds on water quality, results from a study comparing water quality in shallow and deep lakes in New Zealand will be used to infer influences of small dams and their reservoirs. A study by the Ministry for the Environment (2007a) measured nutrient concentrations in lakes throughout New Zealand and found that poorer water quality with higher concentrations of $\mathrm{N}$ and $\mathrm{P}$ existed in small shallow lakes as compared to lakes of more than $10 \mathrm{~m}$ depth. Lower water quality and a tendency towards eutrophication were also found in lakes located in catchments with pasture cover as compared to those with native forest cover (MFE, 2007a). The report cautioned that small lakes were underrepresented in the analysis, but as the results concur with water quality studies elsewhere, it is likely that a larger sample of small lakes would not change the conclusions significantly. The overall findings of the report suggest that the combination of small shallow farm ponds in pasture areas will likely contribute to lower overall pond water quality.

Other studies completed in agricultural regions have concluded that reservoirs reduce downstream nutrient levels. Bere (2007) found that two small onstream ponds in a small catchment in Zimbabwe acted as nutrient sinks, with the highest loading of $\mathrm{N}$ and P measured during the wet season. Cooper and Knight (1990) found a $>70 \%$ nutrient trapping efficiency in a small reservoir for $\mathrm{N}$ and $\mathrm{P}$ and suggested that ponds are "excellent tools for managing intensive agricultural runoff and downstream water quality". However, the study noted that under excessive loading the pond had a reduced capability to trap nutrients. In an Australian study, Baginska et al. (1998) found that particulate P was partially removed from agricultural runoff through farm dams and stream channels. Stanley and Doyle (2002) stated that any form of water storage along the stream 
channel, including pools and backwaters, will decrease nutrient export because the storages allow time for nutrient processing. They suggested that small reservoirs allow a 2 to $70 \%$ reduction in both $\mathrm{N}$ and $\mathrm{P}$ levels between upstream and downstream reaches.

Bosch (2008) modelled N and P export from two catchments in Michigan using the Soil and Water Assessment Tool (SWAT; Arnold et al., 1998). The two catchments had 14 and 88 impoundments respectively, with reservoir surface areas of at least 10 ha. Loads approximately doubled when all impoundments were removed from the watershed model, suggesting that ponds and reservoirs are effective at decreasing nutrient loads. However, along with the decrease in nutrient loads, impoundments had the effect of increasing the annual variability of load exports. This suggests that water residence times and the effectiveness of the impoundment in reducing loads also need to be considered within the modelling framework. The SWAT model also predicted that a large number of smaller reservoirs were more effective at reducing loads as compared to a small number of larger reservoirs (with the same total capacity), and that pond placement near river mouths or point sources of $\mathrm{N}$ and $\mathrm{P}$ allowed for the maximum level of nutrient load reduction (Bosch, 2008).

Reservoirs are sometimes built specifically for the purpose of removing pollutants and improving downstream water quality (e.g. Hossain et al., 2005; Chen et al., 2007). These reservoirs tend to be larger than farm ponds and are primarily built in urban areas where pollutant concentrations in runoff are high. However, studies on the use of small ponds for pollutant removal in agricultural regions have been completed. Harhcegani and Cornish (2003) studied the effects of farm ponds on bacterial exports in an agricultural catchment in Australia and found that the ponds significantly reduced bacterial exports even when water was not detained. They recommended the use of farm ponds and runoff detention basins to reduce pollutant export in the study catchment. Gannon et al. (2005) also found that small reservoirs significantly reduced bacterial counts in streams 
draining stocked pasture lands, although they cautioned that the accumulation of bacteria through sedimentation of the reservoirs could lead to future water quality issues if resuspension occurred.

\section{Summary of small dam effects on water quality}

The quality of water within the reservoir and in downstream reaches will vary significantly with the timing and volume of inflow and outflow from the reservoir, as well as with the volume of constituent loads input to the system. In general, a decrease in $\mathrm{DO}$ and $\mathrm{pH}$, and an increase in water temperature can be expected downstream of farm ponds in agricultural areas. Small reservoirs can also trap nutrients and bacteria, although there is an associated lowering of water quality within the pond and a limit to the volume of pollutants a reservoir can effectively trap. Although ponds are able to trap nutrients, the presence of ponds may also increase the variability of catchment nutrient loads on an annual basis. Downstream water quality will be degraded when systems are overloaded or when dilution is inefficient during critical low flow periods. The only New Zealand study to focus on water quality suggests that small onstream ponds are detrimental to downstream water quality.

\subsubsection{Sediment}

Sediment generation and its transport from source area to stream channel will depend on many variables including characteristics of precipitation, geology, topography, and land use. The majority of sediment transport in a catchment occurs during large infrequent storms (Yorke et al., 1985; Meade et al., 1990). Larger basins will have more available storage, so sediment delivery ratios and sediment yields will be proportionally lower as compared to smaller catchments (Cooke and Doornkamp, 1990). Sediment generation will be higher in agricultural catchments (as compared to forested catchments) because a higher proportion of the total area is covered by bare ground, cultivated soil, and pasture (Neil and Mazari 1993; Allan et al., 1997). A New Zealand study by Fahey and 
Marden (2000) found sediment yield from pasture cover was approximately 2.5 times greater than from a plantation forest.

The presence of dams of any size within a catchment will disrupt sediment movement by trapping it in reservoirs, thereby lowering total catchment sediment yield. The total volume of sediment deposited in a reservoir will depend on the gross erosion of the upstream catchment, the proportion of sediment delivered to the reservoir, and the settling characteristics of the sediment within the reservoir. Some sediment (especially fines in suspension) may move through the reservoir to downstream reaches, particularly in cases where reservoirs have regulated flushing flows and low elevation outlets. Small dams, however, generally have top releases for outflow, so in these cases the majority of sediment will be retained within the reservoir, except at times when ponds are full and storm events contribute to high flows which effectively bypass the ponds. It is likely that in these cases, fine load carried in suspension will bypass the pond completely and continue downstream.

Small ponds have been found to decrease overall catchment sediment yield. Neil and Mazari (1993) used pond sedimentation surveys to determine the importance of various catchment influences on sediment yield. They found a relation between reductions in catchment sediment yield and increases in farm dam numbers. In a modelling-based study in agricultural catchments of New South Wales, Verstraeten and Prosser (2008) estimated that farm dams and larger reservoirs within the catchments had decreased the expected hillslope sediment supply to river channels back to pre-19th century values. The reduction in catchment sediment yield attributed solely to farm dams was predicted at $47 \%$ but this increased to $97 \%$ when large dams within the catchments were included. In cases where livestock have direct access to stock ponds, erosion of pond banks by stock can increase pond sedimentation rates. Lloyd et al. (1998) estimated that $37 \%, 41 \%$, and $85 \%$ respectively of the sediment in the three ponds under study were derived from stock erosion of pond banks. Under certain conditions aeolian 
inputs and sediment from wave erosion of shorelines can also contribute sediment to the pond. These factors must be taken into consideration so as not to over predict the proportion of catchment-derived sediment within the pond.

Trap efficiency is a measure of the retention of sediment within a reservoir, and is described by the fraction of sediment entering a reservoir that is subsequently deposited and retained within it. Vanoni (1975) stated that most large storage reservoirs of modern design trap $>90 \%$ of incoming sediment load, and later studies on large dams have placed this figure anywhere between 50 and 100\% (e.g. Meade et al., 1990; Olley and Wasson, 2003). Studies on smaller structures show a similar range of trap efficiency values. Cooper and Knight (1990) summarised three studies on small reservoirs as having a trap efficiency of 60 to 100\%, while Yorke et al. (1985) found a combined trap efficiency of 35\% for 6 reservoirs behind dams of 2 to $4 \mathrm{~m}$ height on the Schuylkill River, Pennsylvania. Srikanthan and Neil (1989) estimated the trap efficiency of small farm dams in two catchments in New South Wales, Australia at 47\% and 59\%, although the presence of a large dam at one catchment outlet raised the total trap efficiency to $89 \%$. A more recent modelling study in the same area of New South Wales led to similar results, with farm dam trap efficiency estimated at $64 \%$ (Verstraeten and Prosser, 2008). In a study of small farm dams in Zimbabwe and Tanzania, it was found that reservoirs trap virtually all incoming sediment load (Lawrence, 2004).

The range of published trap efficiency values for small reservoirs may be explained by differences both in methods of measurement and in catchment characteristics. Various methods exist for estimating trap efficiency (e.g. Brune, 1953; Heinemann, 1981), including those based on sedimentation indices, or ratios of reservoir capacity to inflow or reservoir capacity to watershed area. These methods have typically been developed on large normally ponded reservoirs, and have been found to be valid for medium to long-term predictions. Small reservoirs typically have different geometric and hydraulic characteristics 
than those on which estimation methods have been based. A numerical model for trap efficiency calculations on ponds less than $0.01 \mathrm{~km}^{2}$ ( $\left.1 \mathrm{ha}\right)$ in area was developed by Verstraeten and Poesen (2001) but has not yet been used extensively. Direct measurement of sediment cores can be used to infer trap efficiency values, but the interpretation process "remains difficult and questionable" (Verstraeten and Poesen, 2000: 248).

The temporal scale of measurement may also affect results. High seasonal and annual variability in trap efficiency has been found in some catchments. For example, Dendy and Cooper (1984) found an average suspended load trap efficiency of $77 \%$ in a 1 ha reservoir over a two year period, with monthly values ranging between 9 and 100\%. Other variables affecting trap efficiency include storm runoff volumes and land cover characteristics (Heinemann et al., 1973), and the size, shape and location of the pond itself (Yorke et al., 1985).

\section{Summary of small dam effects on sediment}

Large reservoirs trap sediment and reduce total catchment sediment yield. Small ponds also trap sediment and reduce catchment sediment yield, but there has not yet been sufficient research to accurately estimate the magnitude of sediment yield reduction. Problems exist with estimation techniques for trap efficiency, sediment yield, and sediment delivery, creating difficulties for the accurate assessment of farm pond influence. Studies on small dams suggest that trap efficiency between 35 and 100\% is possible, although the volume trapped varies on a temporal scale and will be lowest when ponds are full and water and sediment are able to move through the system. It is likely that any trapping of sediment within farm ponds will reduce catchment sediment yield, but the magnitude of this reduction will depend greatly on specific catchment characteristics. 


\subsubsection{Morphology}

The morphology of a stable alluvial channel is largely determined by "the nature and quantity of sediment and water moving through a channel" (Schumm, 1977: 100). Dams of any size will alter the downstream flow regime and retain sediment within their reservoirs, both of which will affect downstream morphology. A decrease in the concentration of sediment in outflows from large dams creates the 'hungry water' situation where water has the energy to carry sediment but no sediment to carry (Kondolf, 1997). This generally leads to excess stream energy and erosion of downstream reaches. Research on large dams has found that decreased sediment supply may scour the bed immediately downstream of the dam if energy exceeds bed material resistance (Williams and Wolman, 1984; Ward and Stanford, 1995). This leads to channel armouring as small particles are transported downstream and coarse particles remain in place. Downstream scour can also lead to erosion of the stream bank, although stabilisation will occur as the new dampened flow regime allows vegetation to become established in the near-bank area (Williams and Wolman, 1984).

Changes to the flow regime after regulation leads to lowered stream power and the loss of channel-forming flood flows. Over the long term, these changes to the flow regime along with bed degradation directly downstream of the dam may result in a narrowing of the channel, aggradation, and building of instream bars (Kondolf, 1997; Surian and Rinaldi, 2004). This response has been observed downstream of medium-sized reservoirs in the United States (Kennon, 1966; Frickel, 1972). Baker et al. (2011) studied the impact of flow diversions and consequent lowered stream discharge on 13 mountain streams in the Rocky Mountains of the USA. They found that limitations to sediment transport capacity led to downstream accumulation of fine sediment (Baker et al., 2011). Overall, the exact downstream response will depend on the magnitude of the change to streamflow and the pre-regulation calibre of channel substrate. The response will be altered if significant sediment sources exist further downstream 
and/or if tributaries deliver sediment to the channel downstream of the dam (Brandt, 2000; Pitlick and Wilcock, 2001).

In other large dam studies, post-regulation changes to channel planform have shown conflicting results. Ligon et al. (1995) reported a shift from a braided stream to a single channel after river regulation, while Merritt and Cooper (2000) found the opposite occurring where a pre-dam deep meandering river shifted to a shallow braided system over a 37 year post-regulation period. The complex interaction of these processes coupled with catchment heterogeneity means that there is not one simple morphological response to regulation.

Few studies have been completed on the effect of small dams on downstream channel morphology. In a paired stream study in Virginia, USA, median grain size in a regulated stream was found to be twice as large as that of an adjacent free-flowing stream, suggesting possible bed scour and channel armouring (Chilton et al., 2004). There was no indication in the study of the spatial extent of change after regulation or of the time frame involved. A somewhat contrasting result was found in a modelled study in New South Wales, where Verstraeten and Prosser (2008) indicated a decrease in downstream erosion rates in association with flow regime changes expected after farm dam construction. The WATEM/SEDEM model (VanOost et al., 2000) predicted a 14\% decrease in erosion rates and a shift towards a supply-limited situation with no deposition directly downstream of farm dams. This finding was explained by the combination of lower rates of sediment delivery to the dam, higher rates of sediment trapping within the reservoir, and reductions in the capacity of downstream flow to carry sediment (Verstraeten and Prosser, 2008).

Only two studies were found which reported changes to channel form after small dam regulation (the lack here is in the number of studies, not the lack of ability to make conclusions following an investigation). In one study, sinuosity was found to have increased by $6 \%$ upstream of a $1.5 \mathrm{~m}$ dam in Ohio over a 33-year period (Evans et al., 2006). Upstream changes were attributed to adjustments in 
channel gradient and the subsequent growth of in-channel sand and gravel bars. After the removal of the dam, decreases in channel sinuosity occurred as sediment was remobilised in the flowing stream. A second study found that a hydroelectric project consisting of two small dams ( $<10 \mathrm{~m}$ high) and a river diversion (which left 10\% of average annual flow in the main channel) resulted in a loss of rapids and riffles, with an increase in pool habitat downstream, as compared to reaches above the dams (Anderson et al., 2006). These changes were associated with lowered stream velocities in the downstream reaches.

Because small dam effects on morphology have not been studied extensively, it may be useful to discuss the theoretical changes expected with a decrease in flow and sediment transport, as would be expected downstream after stream regulation. Schumm (1977) summarised the response of river channels to decreases in discharge and sediment yield in the following formula:

$$
\mathrm{Q}^{-} \mathrm{Qs}^{-} \approx \mathrm{b}^{-}, \mathrm{d}^{ \pm}, \lambda-\mathrm{S}^{ \pm}, \mathrm{P}^{+}, \mathrm{F}^{-}
$$

where $Q$ = stream discharge; $Q s$ = sediment yield; $b$ = channel width; $d$ = channel depth; $\lambda$ = meander wavelength; $\mathrm{S}=$ stream gradient; $\mathrm{P}=$ channel sinuosity (ratio of channel length to valley length); and $\mathrm{F}$ = channel width-depth ratio. The negative sign indicates a decrease from pre-regulation values, the positive sign indicates an increase. The formula suggests that with river regulation, downstream reaches should become narrower with an increase in sinuosity and a decrease in meander wavelength. Changes to channel depth and gradient will depend on the magnitude of change in flow and sediment volume. A subsequent analysis by Brookes (1996) using the same theoretical relationship suggests that a decrease in stream discharge and either a decrease or no change in sediment volume results in a decrease of channel width and depth, an increase in channel slope, and a decrease in the median size of bed material. Warner (1983) investigated the influence of weirs on the Nepean River, Australia and found that channels responded differently based on underlying geology. In the postregulation regime, channels had become deeper in the sandstone gorges, but 
wider and shallower in the intervening shale and alluvial reaches. This suggests that river response to regulation may be more complex than proposed by theoretical relationships.

\section{Summary of small dam effects on morphology}

Extensive research on the effect of small dams on channel morphology does not exist, but the few studies that have been completed suggest that small dams may increase downstream median grain size (Chilton et al., 2004), increase upstream sinuosity (Evans et al., 2006), and decrease the occurrence of rapids and riffles in the downstream channel (Anderson et al., 2006). Many more studies have been completed on large dams, and these generally propose that the response of channels to regulation is extremely variable, depending on site characteristics including pre-regulation channel morphology, bed sediment calibre and cohesion, bank stability, and the magnitude of the post-regulation change. Many of these studies indicate that scour and channel armouring directly downstream of the dam is likely, with changes to channel width and depth dependant on the magnitude of change in the post-regulation regime. Theoretical analyses based on the Schumm formula suggests that a decrease in channel width and depth and an increase in channel slope and sinuosity under regulation is likely (Brookes, 1996), although Schumm (1977) himself points out that regime changes may result in morphological responses that are contrary to these standard relationships. It is therefore likely that there will not be one specific morphologic response to small dam regulation.

\subsubsection{Ecology}

A dam acts as a physical barrier to species movement in both the upstream and downstream direction. The regulation of streamflow further influences riparian vegetation and instream habitat due to flow regime changes (flow volume and timing), changes to sediment transfer (with associated aggradation and/or 
degradation of the channel), and changes to water quality and stream temperature (in both the reservoir and the stream).

The damming of a stream creates a reservoir, adding new lentic habitat while losing lotic and terrestrial habitat, with a corresponding change in species variety and population. Some studies have promoted the construction of small ponds as habitat for frogs, birds, and fish (e.g. Hazell et al., 2001). Brainwood and Burgin (2006) also suggest that farm ponds might be employed as ecologic refuges during extended periods of drought when they are the only reliable sources of water in an area. However, over the longer term, slow eutrophication and sedimentation of the reservoir may have detrimental effects on ecological factors. If eutrophication of the pond occurs, it initially increases food supply but soon limits macroinvertebrate diversity, resulting in a low number of taxa with high abundance (Brainwood and Burgin, 2006). High rates of sediment deposition within the pond (via erosion and/or stock trampling) will also reduce species richness and abundance (Brainwood and Burgin, 2006). If specific management objectives are implemented, these effects may be minimised and regional biodiversity maintained (Markwell and Fellows, 2008).

Ecological studies on regulated rivers suggest that there is a shift towards species better adapted to more stable flows (Pitlick and Wilcock, 2001). In New Zealand, this often means that post-regulation habitats favour exotic species while reducing species diversity (particularly of native species) (MFE, 2000). A study of 15 low-head dams (weirs) over a $171 \mathrm{~km}$ reach of the Fox River in Illinois concluded that the dams "likely had a negative effect on the abundance and diversity of aquatic biota in the river" (Santucci et al., 2005). At a greater distance from the dam there may be a return to natural stream conditions, as found by Anderson et al. (2006) with an increase in species diversity downstream of a dam ( $<10 \mathrm{~m}$ high) in Costa Rica. Changes to the flow regime may affect the timing of life events (e.g. reproduction, spawning) of many species (Charlton, 2008). Changes to channel morphology may also impact habitat, as Ligon et al. (1995) 
found when salmon habitat was affected by the post-regulation planform shift from a braided system towards a single channel.

Aquatic species which are diadromous (spending their life cycle between freshwater and seawater) will also be affected by dams. This is particularly important in New Zealand where almost half of the native fish species are diadromous (Larinier, 2001). These species, including the diadromous species of eel (anguillidae) and whitebait (galaxias), support important commercial, recreational, and traditional fisheries (McDowall, 1993). Large dams usually incorporate a method for fish and eel passage, although high mortality rates are common in passage through hydroelectric turbines or over dam spillways (Larinier, 2001). In New Zealand, small streams do support some of these species, but small dams placed on these streams generally do not include allowance for fish passage.

Apart from physical barriers, downstream changes in water quality and stream temperature will further affect communities of macroinvertebrates and fish (Maxted et al., 2005). A stream with three online ponds (over a distance of approximately $1200 \mathrm{~m}$ ) was monitored to measure the percentage of days with stream temperature above $22^{\circ} \mathrm{C}$ and $26^{\circ} \mathrm{C}$ (Maxted et al., 2005). These temperatures were chosen to indicate, respectively, slight and severe adverse effects on instream native fauna. Results showed a 95\% increase in days with stream temperature above $22^{\circ} \mathrm{C}$ and an $11 \%$ increase above $26^{\circ} \mathrm{C}$ from upstream to downstream reaches (Maxted et al., 2005). A single pond on a second stream showed increases of $87 \%$ for days with stream temperature above $22^{\circ} \mathrm{C}$ but no increase in days with temperature above $26^{\circ} \mathrm{C}$. This suggests that a cumulative effect may occur when multiple ponds are located on the same stream, with temperatures increasing to a higher level as compared to a stream with a single pond. Lessard and Hayes (2003) found that small dams contributed to an increase in downstream temperature which resulted in a shift in macroinvertebrate community numbers, an increase in fish species richness, and a decrease in some 
fish species populations. Similar findings were reported by Mantel et al. (2010) in their study on small dams ( $<15 \mathrm{~m}$ in height) in two regions of South Africa.

Catchments with a high density of small dams were found to affect water quality (particularly total dissolved salts) and water quantity (low flow reduction), and also showed significant reductions in macroinvertebrate index values (Mantel et al., 2010).

The loss of flood flows in the post-regulation system means that the frequency of overbank floods will decrease, and the near-channel water table may also be lowered. This will have an effect on riparian vegetation, decreasing growth rates (Nilsson and Svedmark, 2002), with a possible shift towards species that are more suited to drier upland areas (Nilsson and Berggren, 2000). A study on seasonal streams of the African savannah found that farm dams decreased flow during critical dry years and caused the dieback of some riparian species (O'Connor, 2001). Nilsson et al. (1997) found that regulation affected vegetation by decreasing species numbers and richness in a study of 43 storage reservoirs and 45 run-of-river impoundments in Sweden. They concluded that "the storage reservoirs developed a river-margin vegetation that is permanently different from that in free-flowing rivers" (Nilsson et al., 1997: 800). Braatne et al. (2007) found that cottonwood recruitment on the Yakima River in Washington decreased after river regulation because of the loss of flood flows necessary to scour suitable nursery sites and the loss of high spring flows needed for seedling establishment. Seeds which require streamflow for seed dispersal will also be affected (Nilsson and Svedmark, 2002).

The placement of dams within the catchment will also have an influence on downstream ecology. Lowe and Likens (2005: 196) state: "water quality, biodiversity, and ecological health of freshwater systems depend on functions provided by headwater streams". These functions include, but are not limited to, the maintenance of natural discharge regimes, sediment export rates, and water quality characteristics (Lowe and Likens, 2005). If headwater streams are 
disproportionately dammed, it may have a relatively greater impact on the downstream system. As most of the overall channel length within any given catchment consists of low-order streams, these are often the most directly impacted by land use activities. The importance of headwater streams to the entire system should not be underestimated (Beschta and Platts, 1986).

\section{Summary of small dam effects on ecology}

With the construction of dams, whether large or small, ecological changes to the river system will occur. Shifts in habitat and downstream community composition and abundance are related to changes in the timing and volume of post-regulation streamflow and its influence on sediment transfer, water quality, and channel morphology. The longitudinal disconnection of the river will lead to changes in species abundance and diversity, while changes in flow regime, and in particular the flooding regime, will lead to reduced lateral connectivity between the river and its floodplain, further affecting habitat and riparian vegetation. In New Zealand it has been suggested that a shift to non-native species is likely with post-regulation flow regimes.

It should be noted, however, that dams regulating smaller streams may have a lower diversity of species as compared to larger streams. In particular, this may be the case with regards to small streams in agricultural areas as they generally lack abundant instream diversity and riparian vegetation. The newly created reservoir will also change habitat and species communities, but it has been suggested that small ponds may provide a beneficial source of refuge during critical dry periods. In fact, farm ponds may enhance species diversity and riparian vegetation growth if they are properly managed to this end.

\subsubsection{Other small dam effects}

There are economic advantages to building dams and reservoirs in agricultural areas. Dams increase flood protection and stored water may be used for irrigation supply, thereby opening up new land for development and providing a more 
reliable source of water to areas already under irrigation. Small dams may also be used to ameliorate downstream flow when minimum environmental flows are required under irrigation consent conditions (MFE, 2000; Hume and McGimpsey, 2009). Harris et al. (2006) found that irrigation derived from the Opuha Dam in southern Canterbury, New Zealand, increased total farm revenues by approximately $\$ 40$ million annually. Increased irrigation use and the resulting security of water supply shifted the main type of agriculture practised from cropping and livestock (sheep, beef) to dairy and horticulture. Spin-on effects including job creation and benefits to the local business community were also significant (Harris et al., 2006). The Opuha Dam, however, is a much larger structure than those within the current investigation, and the economic advantage of small farm ponds has not yet been studied. It is likely that farm dams provide direct economic benefits solely to the landholder.

Concerns have been raised regarding the consequence of farm dam failures, with an excellent overview of this issue provided by Pisaniello (2010). Although large dam construction is closely monitored, small dams in many countries are built without engineering expertise or formal consented reviews. The New Zealand Building Act (2004) requires dams that retain over $3 \mathrm{~m}$ water and hold more than $20 \mathrm{ML}$ water volume to have a formal engineering review for safety reasons, but dams smaller than this need no official construction plan or permit (unless they are deemed 'dangerous', in which case the formal review is required).

A further aspect of damming streams in New Zealand is their impact on Maori cultural values. Maori values are intrinsically linked to the sustenance and protection of all natural systems. Any change in the flow regime or water quality of a stream will affect the Mauri or life force of the stream. Mauri is assessed primarily by the productivity of the water body and the food and other material sourced from it (MFE, 2006b). Headwaters are the source of Mauri and are therefore particularly important, and further importance is placed on the maintenance of the stream's natural flow variability, baseflow, ecosystems, and 
riparian areas (Wakefield et al., 2010). One value directly linked to the question of damming is the need for "continuity of flow ki uta ki tai - from the mountains to the sea" (Wakefield et al., 2010: 17). Damming will mean that some mahinga kai (traditional food sources) will be lost because of habitat changes and waahi tapu (sites of cultural significance) may be drowned by flooding for the reservoir (MFE, 2006b). In a cultural impact assessment made for proposed large dams and water storage reservoirs in the Ruataniwha Plains, a concern was raised that the increased demand for water for irrigation will impact the water quality and water flows of the region, and directly affect the area's ecological health (Wakefield et al., 2010). While farm ponds are much smaller than these proposed storages, their cumulative impact is still likely to have an effect on the Mauri of downstream reaches and should be considered within regional water management plans.

\subsubsection{Conclusion of small dam impacts}

While the environmental effects of large dams have been studied extensively, much less is known of the impacts of small dams. Research to date has suggested that small dams will contribute to a decrease in annual runoff volumes and catchment sediment yields. If dams do not have bypass structures, the timing of flow events will also shift with a possible disconnection of the stream occurring until ponds are full and overflowing. Most water quality studies suggest a decrease in water quality downstream of small dams, although the magnitude of degradation will be site specific, with catchment land use and pond characteristics being important influences. Changes to habitat and species diversity and abundance are also likely within a regulated stream system. Small dam regulation will lead to a variety of outcomes because the processes of flow, sediment transfer, and channel dynamics interact in a complex manner over different spatial and temporal scales. The heterogeneity of catchment characteristics, including land use change, will influence these complex processes, further complicating the reaction of the system to its new regulated 
regime. However, by analysing existing studies and adding results of the present research, it is envisaged that a better understanding of small dam processes and their impacts on the larger system will be found.

\subsection{Small dam management}

Although not a lot is known regarding the effects of small dams on the larger system, some countries already have small storages covered within their water and land use management plans. Management strategies range from the voluntary registration of small dams to policies limiting dam construction within certain catchments. The following section introduces a few case studies in regions where farm dam numbers are high and issues regarding their construction have been raised and addressed.

\subsubsection{Australia}

In Australia it is estimated that there are over two million small farm ponds (Australian Water Association, 2007). These ponds have a total stored water volume of $8 \times 10^{6} \mathrm{ML}$, which is approximately $10 \%$ of the total volume stored in large dams (Australian Water Association, 2007). A major mapping project on the Murray-Darling Basin in 2005 found almost 520,000 man-made water bodies over an area of 509,000 $\mathrm{km}^{2}$, representing a farm dam density of $>1 \mathrm{dam} / \mathrm{km}^{2}$ and a total storage capacity of 2.2 million $\mathrm{ML}\left(4.3 \mathrm{ML} / \mathrm{km}^{2}\right)$ (MDBC, 2008). Lowe et al. (2005) found a median farm dam storage value of $4.6 \mathrm{ML} / \mathrm{km}^{2}$ in Victoria with $22 \%$ of all catchments exceeding $10 \mathrm{ML} / \mathrm{km}^{2}$. Volumes are as high as $53 \mathrm{ML} / \mathrm{km}^{2}$ in the Yass River catchment (NSW) and $55 \mathrm{ML} / \mathrm{km}^{2}$ in Broadwater Creek (QLD) (Finlayson et al., 2008).

Farm dam numbers have increased over the past decades. In the Murray-Darling basin, dam numbers increased by an estimated 6\% (a total of 31,000 dams) between 1994 and 2005, with the highest single catchment increase at 18\% (MDBC, 2008). The trend towards more and larger dams has been fuelled by the 
need for irrigation water (Nathan et al., 2004; Van Dijk et al., 2006), and for water security during drought (MDBC, 2008). This has led to further issues, as summarised by the statement: "Left unchecked the number of farm dams will certainly increase and further diminish water availability to existing and future downstream users, and the environment" (Australia Government, 2007: 138). At present, water management in Australia is governed by the National Water Initiative, initially signed in 2004, with all states' agreement by 2006 . The main focus of this initiative is to convert existing water entitlements into share-based entitlements. In each catchment, total water yield is determined yearly and water users within the catchment are granted the right to a proportion of the total yield with trading of entitlements allowed. The environment (i.e. rivers and wetlands) is considered a legitimate user under this initiative (Arthington and Pusey, 2003). The entitlements allow for maintenance of sustainable flow during low-water years and give water users an equitable share of the remaining available water. In terms of farm dam management, in catchments where water is completely allocated these regulations require farmers to obtain an entitlement from another user before any new dams can be constructed, a situation that has occurred in the Murray-Darling Basin (Van Dijk et al., 2006). In catchments where water is still available for allocation, farm dam regulations either place limits on catchment water harvesting, require the licensing of dams used for irrigation or commercial purposes, or place caps on new farm dam construction. Many of these regulations hold for both onstream and offstream storages. In other jurisdictions it is expected that farm ponds will be under more government regulation in the future (Land \&Water Australia, 2008).

\subsubsection{United States}

In the United States small dams do not usually require consent for building. However, with the number of reservoirs increasing significantly since the 1990s, some states (e.g. Arizona, California, Oregon) now require the registration of 
small water impoundments (Bulman, 2004). Consents are not needed for construction of these dams unless they are over a certain volume (e.g. $12 \mathrm{ML}$ in California), or are constructed on or near a navigable waterway (e.g. Wisconsin). The registration process is primarily meant as a means to allow water managers to monitor dam development.

In California's Napa Valley, the use of water to protect grape vines from frost led to very high instantaneous demands on river water beginning in the 1960s. As a response, the construction of small offstream water storages was encouraged by local and state governments (Bulman, 2004). These storages were filled through streamflow diversions at times of high flow. However, by the 1990s, the cumulative volume of these small storages was larger than streamflow volumes and streamflow diversions began to impact the larger system. Impacts included a change to annual streamflow volumes, groundwater storage, and the seasonality of water supply. Water management in the area now requires the registration of all storages so baseline information can be collected. Controls can also be placed on the amount, rate, and times of water diversions to fill storage ponds. Further management policies are likely to be implemented as water demand in the area continues (Bulman, 2004).

\subsection{Water use and management in New Zealand}

\subsubsection{Water use}

New Zealanders are high consumptive water users, using 2 to 3 times more water per capita as compared to most other OECD countries; however, allocated water takes comprise less than $5 \%$ of New Zealand's total freshwater resource (MFE, 2006a). Actual water use is lower than allocated volumes, as not all consented takes are actually used. National estimates of the proportion of allocated water that is used vary between 20 and $80 \%$ of allocated volumes (MFE, 2006a), but these estimates will soon become more robust. Under the new Resource 
Management (Measurement and Reporting of Water Takes) Regulations 2010, any consented take of $5 \mathrm{~L} / \mathrm{s}$ or higher (unless for household use or under a permitted activity) will need to be monitored. These regulations will increase monitored water abstractions from 66\% currently to $92 \%$ in 2012 and to $98 \%$ by 2016, leading to more accurate accounting of the total volume of water used in New Zealand.

Irrigation is currently the highest allocated water use (77\% of total) and provides irrigation to 970,000 ha of land in New Zealand, including 40,000 ha in the Hawke's Bay region (MFE, 2006a). The area of consented irrigated land in New Zealand has increased by 55\% each decade since 1965 (MFE, 2000). Agricultural intensification has occurred throughout New Zealand's history, from the clearing of forest for pasture at the turn of the last century to recent increases in the dairying sector. In the decade between 1990 and 2000, there was a $>50 \%$ increase in land used for dairying in New Zealand, with the value of total dairy exports nearly doubling between 2006 and 2009 (Stats NZ, 2010). This recent change in land use has had a corresponding change in water use and demand. Dairy farming has the highest required volume of water use within the agricultural sector, with water used for pasture irrigation, stock drinking, and dairy shed washing. A study on New Zealand dairy farm water use between 1997 and 2000 estimated total annual water use to be over $1 \times 10^{6} \mathrm{ML} / \mathrm{y}$ (Flemmer and Flemmer, 2007). If dairy conversions continue at their current rate, a much greater volume of water will be needed in the future.

Demand for water in agricultural areas is also projected to be higher in some regions under climate change scenarios. An increase in temperature and decrease in annual precipitation volumes (along with an increased likelihood of drought) is predicted for all east coast agricultural regions in New Zealand (Waikato, Gisborne, Hawke’s Bay, and Canterbury) (Mullan et al., 2001). The combination of increased water demand and predicted climate change will affect the volume of available water and the security of water supply for farmers in some regions. In 
response, it is likely that farmers will build more and larger storage ponds for a secure supply of on-farm water. In mid-Canterbury, the size and number of farm dam storages has increased over the past few years from a typical capacity between $30 \mathrm{ML}$ and $60 \mathrm{ML}$ to an average now of approximately $120 \mathrm{ML}$ (Hume and McGimpsey, 2009). Federated Farmers is advocating water storage as a solution to New Zealand's water scarcity issues (Federated Farmers, 2008). Bright and Morgan (2003) state that significant volumes of water storage will need to be developed in the future to keep up with the demand for irrigated water in New Zealand.

\subsubsection{Water management and security}

At present, management of fresh water is included under the Resource Management Act (RMA, 1991), administered by the Ministry for the Environment. Regional and district councils use this legislation to produce regional policy statements and regional plans. The RMA includes provisions for "controlling the taking, use, damming and diversion of water and the control of the quantity, level and flow of water in any water body". The preservation of fisheries and fish habitat is legislated under the Conservation Act (1987), administered by the Department of Conservation. A further regulation (Freshwater Fisheries Regulations 1983) deals with restoring migratory access for migratory fish.

In addition to the RMA, the Sustainable Water Programme of Action was established by the Ministry for the Environment and the Ministry of Agriculture and Forestry and ran from 2003 until 2008. Its purpose was to ensure the sustainable management of freshwater resources in New Zealand through new frameworks to improve water quality and reliability of supply. In 2009, the government introduced the New Start for Freshwater (MFE, 2009) which carries over a few initiatives from this initial work, whilst outlining a new direction for water management decisions to incorporate a stronger economic focus. The 
initial policy paper suggests that after environmental flow levels are considered, the remaining available water should go to high value uses. Water storages are listed in the document as infrastructure options for future water management strategies.

The Ministry of Agriculture and Forestry has addressed water scarcity issues with a number of incentives for building water storages, aimed particularly at community storage schemes. The Community Irrigation Fund and the Sustainable Farming Fund both have money available for the development and implementation of community schemes which reduce risks associated with probable future water shortages. The Community Irrigation Fund has earmarked \$6.4 million for projects running from 2008 to 2016. Projects which have been funded include water diversions, new water storage construction, and enlargement of existing reservoir storages.

Small dam construction is administered through the resource consent process, with slight variations existing amongst regional councils. Hawke’s Bay Regional Council permits dams, weirs, and other structures in rivers and lakes as long as the reservoir is no bigger than $20 \mathrm{ML}$, the height of the structure is no greater than $4 \mathrm{~m}$, and the upstream catchment area is no larger than 50 hectares. If a dam is larger in size than outlined, resource consent is required. A further consent is needed if water is to be removed from the pond for irrigation purposes. Reasonable takes of water for stock or household use do not need consent. With the introduction of the Building Act (2004), building consent is now required for any dam which is greater than $4 \mathrm{~m}$ in height, and holds water to $3 \mathrm{~m}$ or more in depth or $20 \mathrm{ML}$ or more in volume. These regulations were primarily brought in to guarantee the safety of structures being built. However, it is anticipated that these regulations will result in many farmers choosing to build new dams at sizes below the specified regulated limits (Hume and McGimpsey, 2009). If they are built smaller than Building Act regulations, the farmer can apply for the regular regional council resource consent (which is relatively 
straightforward to receive) rather than having to carry the additional cost of hiring a registered engineer to oversee dam construction as is required under the building consent process. Federated Farmers are pushing for lower regulation and minimal compliance costs for farm dam construction, even for those dams that are larger in size than the Building Act or regional council consent limits (Hume and McGimpsey, 2009).

Auckland Regional Council requires more stringent conditions than the Building Act regulations. Dams of any size which are built on perennial streams must have a minimum impact on downstream ecology and flow regimes. Any consent which allows takes from dams on permanent streams must ensure the maintenance of downstream low flows, flow variability, lake and wetland levels, and freshwater ecosystems (ARC, 2010). The concern is that the majority of the region's freshwater diversity is on $1^{\text {st }}$ and $2^{\text {nd }}$ order catchment streams which are most often the ones that are dammed. The management plan encourages the use of offstream dams rather than onstream dams, with new dams on permanent streams strongly discouraged. No restriction presently exists on the damming of intermittent streams, as the council is seeking more information on intermittent stream habitat and potential impacts before a specific management plan is introduced (ARC, 2010). Existing dams on permanent streams which are causing adverse effects are recommended to be decommissioned unless the effects can be avoided, remedied, or mitigated. Suggested mitigation measures include riparian planting, the installation of low flow bypass structures, wetland creation, and/or provisions for fish passage (ARC, 2010).

Other options to water security exist and are being investigated. Water harvesting options whereby offstream ponds are filled with abstracted streamwater during high streamflow periods have been suggested (Robb, 2001). In this manner, more small dams could be built without increased allocation (as takes would not occur during low flow periods as at present) (Hume and McGimpsey, 2009). Coupled with the full development of groundwater resources, 
it is suggested that these actions could "meet foreseeable water demand while improving the level of protection given to instream values" in New Zealand (Robb, 2001: 8). As many councils are promoting water storage as the best option for future water security, the question remains as to how these solutions might impact the larger system and how these impacts might best be mitigated.

\subsection{Summary}

In New Zealand, agricultural intensification is seen as a main driver of economic development, and water is seen as the limiting factor to this growth (HBRC, 2003). Agricultural output is increased through corresponding increases in stocking, fertiliser application, and water use. As most groundwater and surface water supplies in agricultural areas are already at the limits of allocation, the success of agricultural intensification in New Zealand will hinge on the acquisition and proper management of water supplies. This is necessary from both an economic and an environmental point of view. As stated by the Ministry for the Environment (2009): "Sound water management is essential to provide for New Zealand's economic development and growth, and to maintain social and cultural values.”

Water storage (onstream and offstream) is being promoted as an option for future water security in New Zealand. It is expected that small dams will continue to be constructed, resulting in a further impact on streams owing to the removal of additional volumes of water. At present, there is very little knowledge of the impact of small dams on streamflow, water quality, sediment transfer, and channel morphology in New Zealand. Additionally, there are no policies in place to manage small dams and mitigate any potential effects. The lack of knowledge of small dam impacts and their importance to water management in New Zealand are the drivers for the present study. 


\section{Location of Study}

The current study has two components - a field-based paired catchment study to investigate the effects of small farm dams, and a larger scale catchment-based modelling study to determine the cumulative impacts of farm dams on downstream flow and to provide possible farm dam management options. The catchments under study are located in the Ruataniwha Plains area of central Hawke's Bay, the description of which will be the focus of this chapter.

Hawke's Bay is located on the eastern coast of the North Island of New Zealand (Figure 3.1). It includes the Ruahine and Kaweka Ranges to the west, the rolling hills and plains in central areas, and the eastern coastal hills. The highest proportion of agricultural activity in the region is in the Heretaunga Plains and the Ruataniwha Plains. As the Heretaunga Plains are already intensely developed and urbanised, most of the recent agricultural land use intensification has occurred in the Ruataniwha Plains (HBRC, 2009).
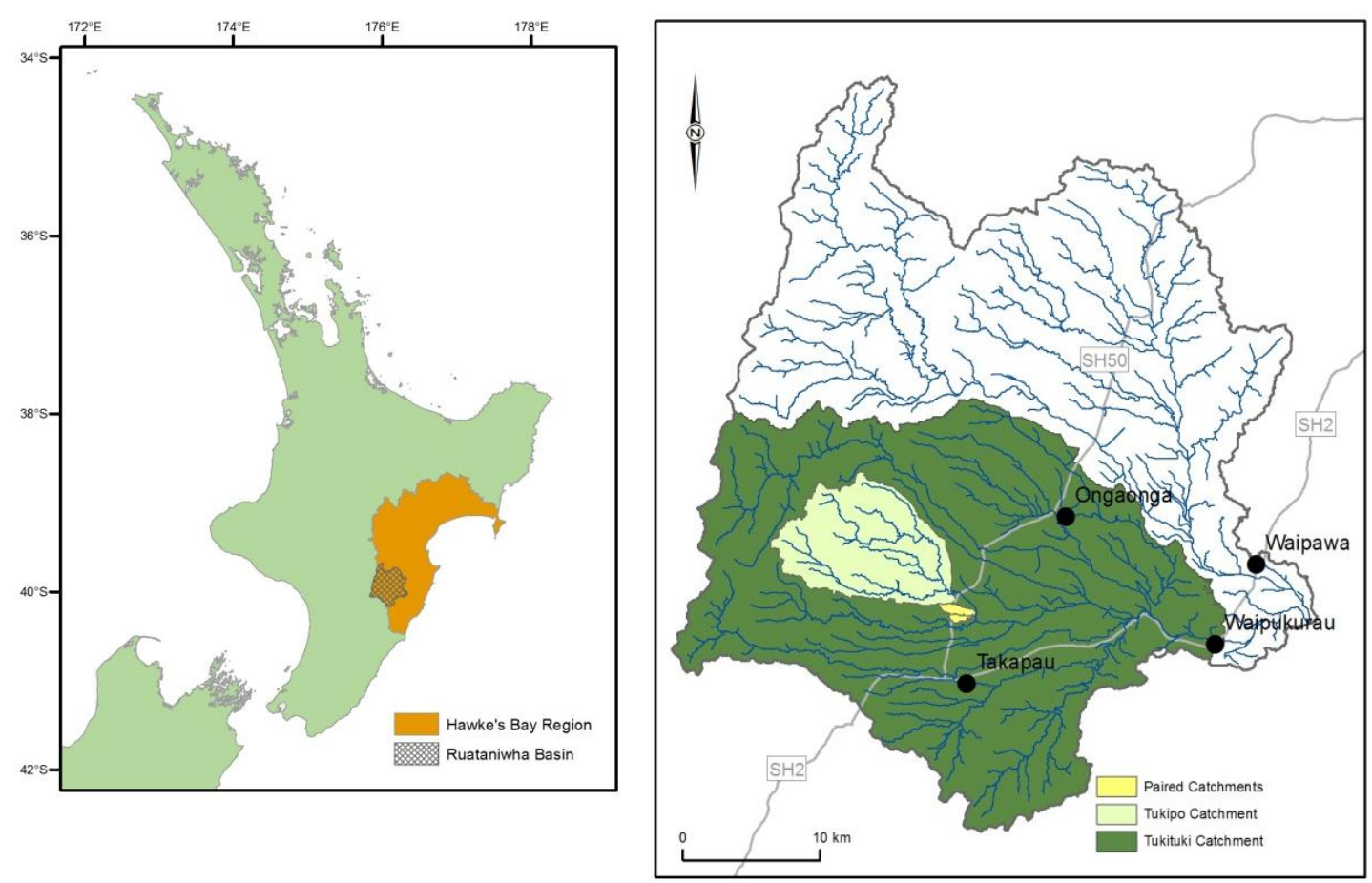

Figure 3.1: Study site location showing Ruataniwha Plains, Upper Tukituki, Upper Tukipo, and paired study catchments within the Hawke's Bay region. 
The study was conducted in the Ruataniwha Plains because the normally dry summer conditions often progress into periods of drought, resulting in critical water shortages in the region. The area has most recently had significant dry periods in 2007, 2008, and 2009. Surface water in the Ruataniwha Plains is fully allocated and new shallow groundwater takes are on hold pending further scientific investigation (Tonkin and Taylor Ltd., 2009).

The field-based study was undertaken on adjacent farms: the Kimberley regulated catchment $\left(0.7 \mathrm{~km}^{2}\right)$ and the Tukipo Terraces unregulated catchment $\left(1.5 \mathrm{~km}^{2}\right)$. These sites were chosen because of their accessible paired study location. The modelling study was undertaken in two catchments: the Upper Tukipo catchment $\left(85 \mathrm{~km}^{2}\right)$, which is nested within the Upper Tukituki catchment $\left(740 \mathrm{~km}^{2}\right)$. All four study catchments are shown in Figure 3.1. The headwaters of the Tukituki River are located in the Ruahine Ranges; the Tukipo River headwaters start at a lower elevation in the foothills. The Tukipo River flows east until it joins the Tukituki River $6 \mathrm{~km}$ west of Waipukurau, whereupon the Tukituki continues in a northeast direction and finally drains into Hawke Bay. The Upper Tukipo River was chosen as a representative catchment in the region because of its long continuous flow record (1976-present) and its status as "the best representative intermontane stream in the Ruataniwha Plains region" (McGuinness, 1984). The Tukipo River has the only long-term flow recording site on a 'true Plains stream' in the Ruataniwha Plains (HBRC, 2003).

\subsection{Geology and Topography}

The Ruataniwha Plains are formed within an $800 \mathrm{~km}^{2}$ fault-bounded basin formed on pre-Quaternary basement rock and filled with highly permeable Quaternary and Holocene sediment. The entire basin tilts south-eastwards, with the greywacke Ruahine Range bounding the western edge and the Raukawa Range bounding the east. 
The Ruahine Range is composed of Triassic-Jurassic greywacke that has been uplifted over the past two million years (HBRC, 2003). The eastern ranges (Raukawa and Turiri) are Tertiary siltstone, sandstone, and limestone of the Otane Anticline, and also represent the basement rock of the Ruataniwha Plains basin. The eastern and southern areas of the basin were inundated by the sea two million years ago, resulting in depositional sequences of shallow-water coastal, estuarine, and lagoonal sediments. This was followed by slow uplift and deposition of coarse alluvial sediment (primarily derived from the uplifted and eroding Ruahine Range) across the whole basin. The uplift of the Otane Anticline eventually excluded the sea from the basin from 500,000 years ago. The filling of the basin continued through the Quaternary and into the Holocene, resulting in a heterogeneous basin comprised of sequences of alluvial gravels with intermittent clay layers of varying thickness (Baalousha, 2009).

The plains represent a composite of as many as five separate gravel terraces (Ludecke, 1988). Rivers have eroded through these gravels to form multiple gravel-bed channels with highly fluctuating flow. Headwaters of these rivers are in the Ruahine Range or lower elevation hill country, with rivers flowing onto the plains and eventually joining either the Tukituki River or Waipawa River before exiting the mouth of the basin near the towns of Waipukurau and Waipawa. The Ruahine Range is still in an eroding phase and much of the sediment derived from anthropogenic vegetation clearing beginning in the 1800s has likely not yet reached the lowland areas. This sediment is currently stored in the mid-sections of the major rivers flowing through the area (Grant, 1965; Williams, 1985). Although Williams (1985) states that the main rivers of the Ruataniwha Plains are in a state of aggradation, recent studies on the Waipawa River suggest the river is now undergoing degradation (Toleman, 1999; Schwendel et al., 2010).

The geologic basin of the Ruataniwha Plains, as defined in Hawke’s Bay Regional Council reports, includes the low-lying plains between State Highway 50 (SH50) 
and the eastern Raukawa Range as well as the lowland river valley bottoms northwest of SH50. The area covers approximately $800 \mathrm{~km}^{2}$, with elevations ranging from 150 to $500 \mathrm{~m}$ asl. To define the area based on hydrologic terms, the entire catchment area of the rivers flowing through the basin must also be included, giving a total area of approximately $1500 \mathrm{~km}^{2}$. This is an important distinction, as runoff and sediment is derived from the higher hills and mountains of the Ruahine Range, with maximum elevations in excess of $1700 \mathrm{~m}$ asl. For the purpose of this research, 'Ruataniwha Plains' or 'Ruataniwha Plains catchment' will refer to both the plains and upland catchment areas, while the term 'Ruataniwha Plains basin' will be used when referring to the extent of the geologic basin.

\subsection{Climate}

\subsubsection{Climate norms}

The climate of New Zealand is determined by its position in the zone of Southern Hemisphere westerly airflow. It has a temperate maritime climate with regional variations primarily dependent on latitude and proximity to mountain ranges. The Hawke's Bay region is protected from the predominant westerly air flow by the western mountain ranges, resulting in less wind, milder winters, and drier summers than elsewhere in the country. Warm summers (daily mean January temperature $=13.0$ to $24.2^{\circ} \mathrm{C}$ ) and cool to mild winters (daily mean July temperature $=3.2$ to $13.8^{\circ} \mathrm{C}$ ) are typical of the Ruataniwha Plains area (HBRC, 2003). Average daily temperatures (minimum, maximum, and mean) for the period 1999-2009 as measured at the Ongaonga climate station are summarised in Figure 3.2. Although the location of the western mountain ranges contributes to less windy conditions overall, the area is more vulnerable to easterly cyclonic systems which occasionally bring large storms of high winds and heavy rainfall 
(McGuinness, 1984). These storms occur most frequently between December and April (Salinger et al., 2004).

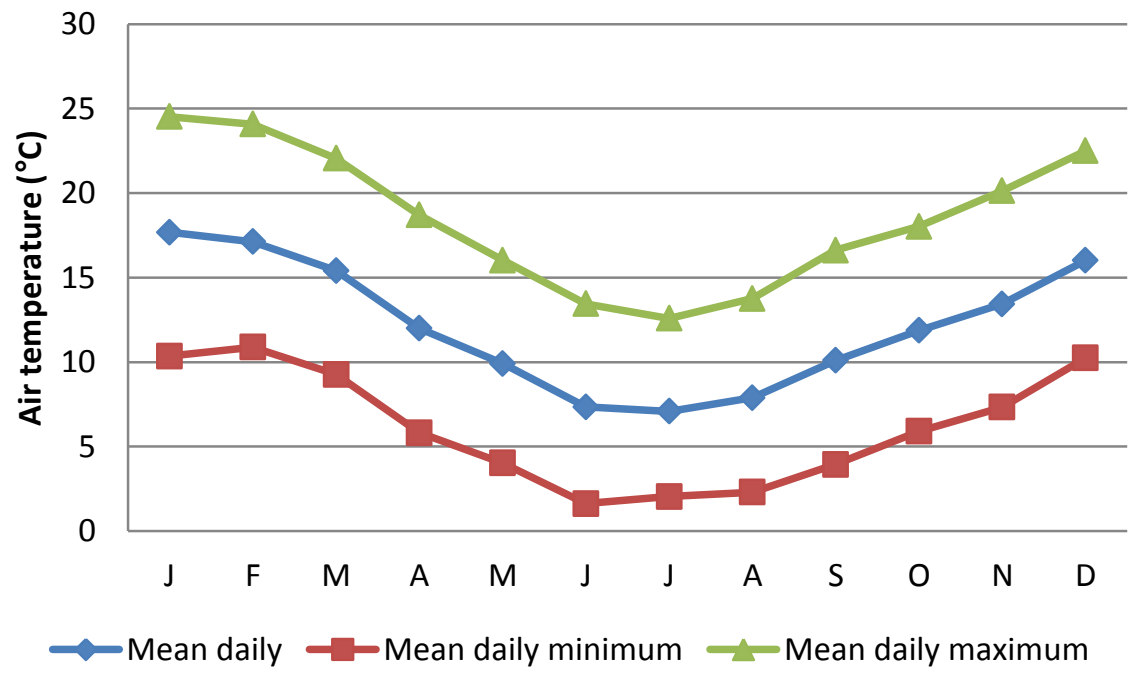

Figure 3.2: Daily air temperature averaged by month as measured at Ongaonga station, 1999-2009.

Annual precipitation totals in the region range from 800 to $1200 \mathrm{~mm}$ on the plains to 1600 to $2400 \mathrm{~mm}$ in the mountains. This is summarised in Figure 3.3 using 30-year average monthly rainfall values for two Ruataniwha Plains stations: Ongaonga (214 $\mathrm{m}$ asl) and Moorcock (600 m asl). In general, months of highest precipitation volumes are July (resulting from winter low pressure systems) and March (resulting from the easterly cyclonic storms). However, variability of rainfall is quite high on both an annual and monthly basis, with an annual variability $>16 \%$ for the Hawke's Bay region and a monthly variability as high as $70 \%$ between January and April. Rainfall variability is measured by the mean of differences between each annual total and the long period mean, expressed as a percentage of that mean (Ministry of Works, 1971). There has been a slight decrease in annual rainfall over the period 2004-2009, as shown at 82\% (of 11 analysed rainfall sites) in the Hawke's Bay region (HBRC, 2009). Between 2004 and 2009, the September to April period has shown a significant decrease in total rainfall volumes (HBRC, 2009). This has impacted farming in the area, because it 
has led to decreases in soil moisture levels and available water in the period between spring and early autumn.

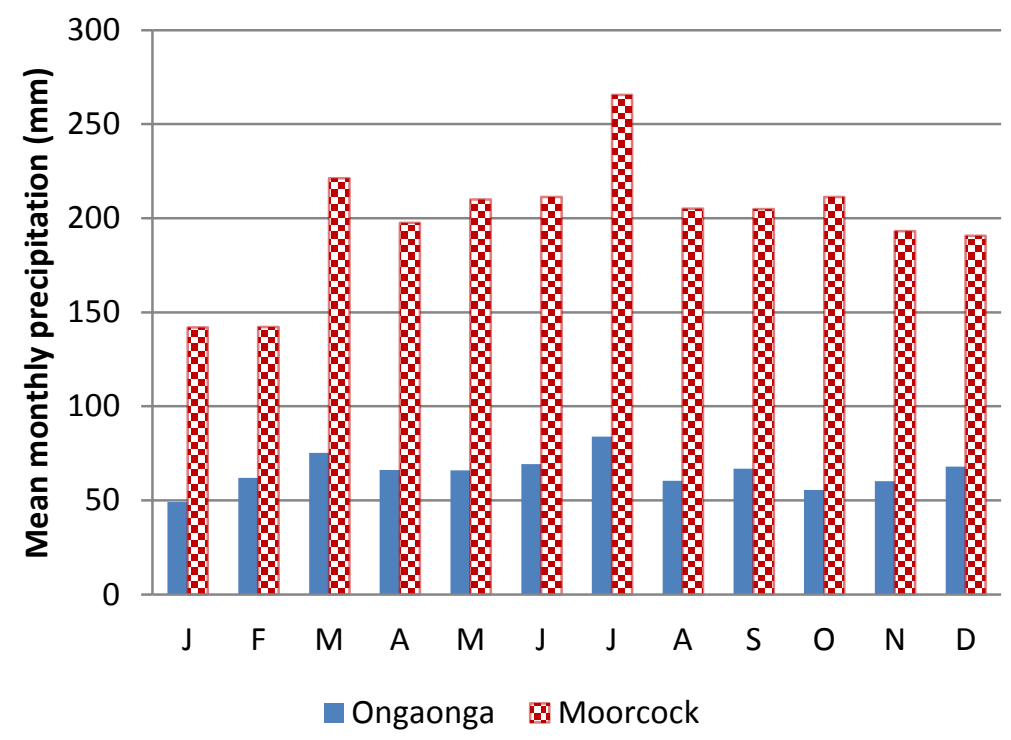

Figure 3.3: Average monthly precipitation at Ongaonga ( $214 \mathrm{~m}$ asl) and Moorcock (600 $\mathrm{m}$ asl) (1979-2009) showing general precipitation trends and the influence of elevation on precipitation volumes in the Ruataniwha Plains region.

Thompson (1987) estimated potential evapotranspiration (PET) for the Ruataniwha Plains basin at $866 \mathrm{~mm} / \mathrm{y}$ and Baalousha (2009) estimated actual evapotranspiration (ET) for the same region at $528 \mathrm{~mm} / \mathrm{y}$ using the water balance approach. Little spatial variation exists in ET across the Hawke's Bay region (HBRC, 2003) and rates are highest in the summer $(140 \mathrm{~mm} / \mathrm{m})$ and lowest in the winter $(20 \mathrm{~mm} / \mathrm{m})$. Rates of ET increase under the influence of the strong northwest winds which occur primarily in the spring, summer, and autumn (HBRC, 2003).

Rainfall variability throughout the region means that both drought and flooding are likely scenarios in any given year. Drought is most common in the spring and summer (September to March) and flooding is most likely to occur with the heavy rainfall associated with easterly cyclonic systems (December to April). Major droughts occurred in the Hawke’s Bay region in 1976, 1982/3 and 1986 which greatly affected agricultural production (Ludecke, 1988). More recently, official droughts were declared in the Hawke’s Bay region in 2007, 2008 and 2009 
(MAF, 2009). Between 2004 and 2008, flood events were recorded in five localities in the Hawke's Bay region. The two largest floods occurred on 18 Oct, 2004 and 17 July, 2007 with insurance costs of \$5.25 million and \$1.11 million respectively (based on 2007 values; Insurance Council of NZ, 2009).

\subsubsection{Shifts from normal climate patterns}

Changes from normal weather patterns in New Zealand result from El Niño, La Niña, and the Interdecadal Pacific Oscillation (IPO). Both El Niño and La Niña events are cyclic and are enhanced to varying degrees every 3 to 7 years. Enhanced summer westerly flow and winter southerly flow are more likely to occur during El Niño events, resulting in colder than normal winter temperatures across the country, wetter western areas, and drier eastern ones (Mullan, 1995). In the Hawke's Bay region, this often means an increase in the likelihood of drought (Griffiths, 2007). The opposite effect occurs during La Niña events, with an enhancement of winds from the northeast resulting in higher rainfall volumes for the Ruataniwha Plains. This effect is heightened by the occurrence of extratropical cyclones which more frequently reach the northeast of New Zealand during La Niña events. The IPO has a cycle which moves from enhanced to weakened westerly circulation every 20 to 30 years. Although the IPO can exacerbate conditions when associated with El Niño and La Niña events, it has been found to have no statistically significant effect on climate or river flow regimes in the Hawke's Bay region (McKerchar and Henderson, 2003; Wood, 2003).

Climate change predictions for New Zealand suggest that along with increased annual temperatures, wet regions will receive more precipitation and dry regions will receive less precipitation (MFE, 2008). For the Hawke’s Bay region, A1B predictions (based on a mid-range scenario of $\mathrm{CO}_{2}$ output and economic growth) include an increase in annual temperatures by $0.9^{\circ} \mathrm{C}$ between 1990 and 2040, with slightly higher increases $\left(+1^{\circ} \mathrm{C}\right)$ for summer and autumn and slightly lower 
increases for winter and spring $\left(+0.8^{\circ} \mathrm{C}\right)$. Precipitation predictions for the A1B scenario in the Hawke's Bay region include a decrease in total annual precipitation volumes of $3 \%$ to 2040 . This prediction has a moderate confidence level placed on it, meaning it is "more likely than not to be correct in terms of indicated direction and approximate magnitude of change" (MFE, 2008). There is a greater seasonal variability predicted, ranging from a summer and autumn increase in precipitation $(+4,+5 \%$ respectively) to a winter and spring decrease in precipitation $(-13,-7 \%)$. The uncertainty associated with these predictions is high. As an extreme example, the lower and upper limits for predicted summer precipitation change in the Hawke's Bay region are $-33 \%$ and $+38 \%$ (MFE, 2008). Along with changes to total precipitation volumes, climate change predictions show the Hawke's Bay region receiving fewer precipitation events, but those that occur will be of higher intensity. In areas of New Zealand that are currently prone to drought, which includes the Ruataniwha Plains, drought risk is expected to increase under predicted climate change scenarios. Specifically, it is predicted that the Napier 1 in 20 year drought event will shift to a 1 in 9.5 or 1 in 2.5 year event by 2080 under low to medium and medium to high scenarios respectively (Mullan et al., 2005). The same report also predicts that the timing of droughts will shift into the spring and autumn more often than currently is the case.

\subsection{Soils}

The soils of the Ruataniwha Plains are divided broadly into three groups based on their formation on high, intermediate, or low terraces (HBRC, 2003). High terrace soils are more than 15,000 years old and form from loess deposits. These soils are silt loams on gleyed silt loam on a slightly cemented pan. Intermediate terrace soils are derived from former fan deposits up to 10,000 years in age and typically have sandy loams on ashy loams on stones. Low terrace soils have shallow stony soils less than 2000 years old. All three types tend to be better drained on higher land and poorly drained in lower areas and depressions 
(HBRC, 2003). Some tendency towards gleying will occur in areas of poor to very poor drainage. Both the Upper Tukipo and Upper Tukituki study catchments have all three terrace types represented, with high terrace soils being the most common.

Permeable soils in the Ruataniwha Plains can drain to field capacity within 48 hours of the end of a rain event (Griffiths, 2004). Soils with low permeability will take much longer to drain (from days to weeks) depending on rates of infiltration, plant water uptake, and evapotranspiration. In some cases, artificial drainage may be required to prevent long-term saturation of the soil (HBRC, 2003). Intermediate terrace soils generally have good drainage, while most high terrace soils have imperfect drainage (HBRC, 2003).

Specific soil characteristics, including susceptibility to compaction and available water capacity, have an effect on land use capabilities in the area. For the most part, soils in the region are best suited for pasture, although some lowland soils do have good irrigation potential for cropping and horticulture. In the Upper Tukipo catchment, susceptibility to compaction tends to be moderate to high, with higher susceptibilities related to increasing proportions of fines in the soil. These same soils have low to moderate available water capacities (water available to plants), suggesting that shallow-rooting plants such as grass may be better suited for these soils. If these soils become degraded under specific land uses, significant problems to soil structure and increased soil compaction may occur. The highest compaction values will occur with intensive bull beef farming systems, although dairying, orchard, and extensive sheep and beef farming may also lead to compacted soils (HBRC, 2009). Intensive farming can also contribute to the degradation of carbon to nitrogen $(\mathrm{C}: \mathrm{N})$ ratios, which have been declining in the region in recent years (HBRC, 2009). In terms of soil contaminants, measured concentrations of heavy metals fall mostly within guideline levels (with the occasional exceedance of copper and zinc), but levels are predicted to 
increase in the future with continued agricultural intensification in the region (HBRC, 2009).

Wind erosion is a concern in the Ruataniwha Plains region. Although soil derived from volcanic ash or loess is most susceptible to wind erosion, the sandy loam soils of the intermediate terraces also have high aeolian erosion susceptibilities (HBRC, 2003). At present, these areas are most likely to be under pasture grass, thereby reducing the likelihood of erosion. However, with continued agricultural intensification in both the catchment and the larger region, the erosion of these soil types may become an issue in the future (McDonald and Patterson, 2003).

The degree to which the Ruataniwha Plains area is further intensified (in an agricultural sense) will ultimately depend upon available water supplies. The volume of water required will depend on the needs of crops and the characteristics of the soil. Although precipitation variability is quite high (both seasonally and annually), the growing season (September-May) is generally the driest and this is when the availability of water will be the most critical. The Ministry of Works (1971) determined soil moisture deficiencies for the entire Hawke's Bay region by measuring the percentage of growing seasons during which soil moisture reserves would be depleted by more than $7 \mathrm{~cm}$ at some point in the season. The soil moisture deficit of the Upper Tukipo catchment is between 40 and $80 \%$ (increasing towards the south and east), suggesting that some sort of irrigation system would be necessary to ensure adequate water supplies for continued agricultural development in this area.

\subsection{Hydrology}

\subsubsection{Groundwater}

Primary groundwater resources in the Hawke's Bay region lie within the confined and unconfined aquifers of the Heretaunga and Ruataniwha Plains 
(HBRC, 2009). Groundwater sources supply $70 \%$ of water used in the Ruataniwha Plains and 95\% of these groundwater withdrawals are for irrigation. In 2009 there were 536 bores on the Ruataniwha Plains, of which at least 336 were active (HBRC bore database). Groundwater quality is generally good throughout the region and the basin (HBRC, 2009).

The Ruataniwha Plains area is a closed basin with no groundwater input from outside, meaning groundwater is recharged solely by infiltration of precipitation and surface water (Baalousha, 2009). Aquifers are found within the underlying sand and gravel layers, with the highest yields derived from older gravels. These older gravels are expected to be thickest in the north and west of the basin, thinning towards the east and south (Brown, 2002). The piezometric map of existing bores in the Ruataniwha Plains reveals a horizontal movement of groundwater towards the east and southeast mirroring surface water movement (Luba, 2001). Groundwater discharge occurs as gains to streamflow through springs, seeps, or subflows to the Waipawa and Tukituki Rivers at the southeastern edge of the basin (HBRC, 2003).

Measured yields of most bores in the eastern region of the basin are less than $300 \mathrm{~m}^{3} / \mathrm{d}$, but some yields reach $2000 \mathrm{~m}^{3} / \mathrm{d}$ (Luba, 2001). This range is classified as good for domestic use, and poor to fair for irrigation (HBRC, 2006b).

Groundwater levels are drawn down in the summer with takes for irrigation, but normally recover with precipitation recharge over the winter. Over a 20-year period of record, aquifer levels have shown an overall decline, with average water level decreasing by $0.4 \mathrm{~m} /$ decade (HBRC, 2006). The greatest decline, occurring at the eastern edge of the basin, is 1 to $2 \mathrm{~m} /$ decade (HBRC, 2009). With agricultural intensification expected to continue in the region, it is likely that groundwater withdrawals will increase. At the basin outlet under maximum groundwater development there may be associated decreases in surface water discharge. The lowering of the groundwater table will reduce recharge occurring through springs and seeps and will increase the likelihood of surface water 
seeping into the streambed (Bredehoeft, 2002). Although it is known that groundwater abstraction reduces natural spring flows, it is unknown how pumping of water from shallow aquifers might affect nearby stream reaches (HBRC, 2006b). Further discussion on the regional council's plans for irrigation development in the area is included in Section 3.8.

\subsubsection{Surface water}

Because of the relatively small size of most New Zealand catchments, streamflow response is closely linked to rainfall events (Jowett and Duncan, 1990), with antecedent moisture levels within the catchment affecting the timing and volume of this streamflow response. Streams in the Ruataniwha Plains region show a flashy response to rain events. The average characteristics of flow in a river can be shown by a flow duration curve, which represents the proportion of time when flows of a certain volume are equalled or exceeded. Flow duration curves based on mean daily flow records (1987-2009) for the Tukipo and Tukituki Rivers are shown in Figure 3.4 .

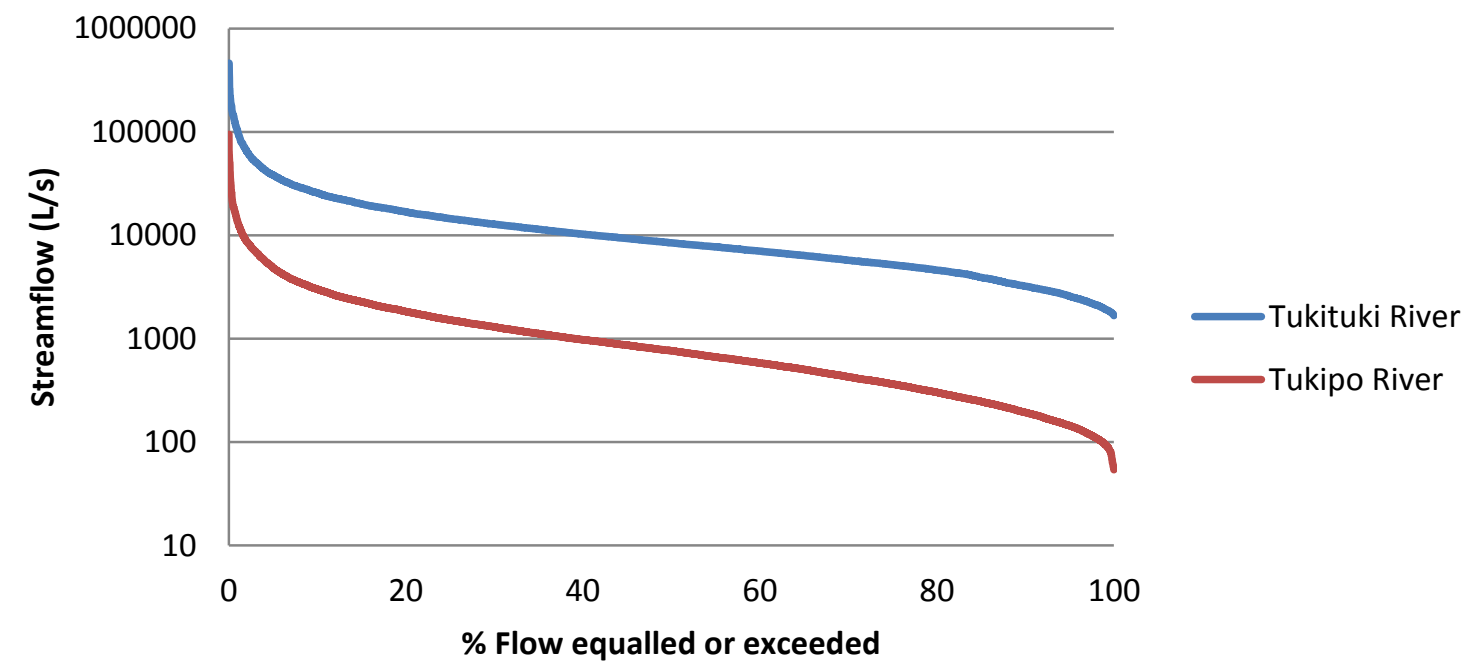

Figure 3.4: Flow duration curves for the Tukipo River (at SH50) and the Tukituki River (at Waipukurau), based on mean daily flow, 1987-2009.

Runoff generation studies have suggested that saturation overland flow is the dominant storm runoff process in New Zealand (Davie, 2004). This occurs in areas where the water table is close to the surface and rises during rainfall events 
to intersect the soil surface. Saturation overland flow occurs primarily on concave surfaces or where a subsurface saturated wedge develops at the bottom of a slope. Infiltration excess overland flow (Horton-type) is unlikely to occur, as most soils in the region have high infiltration capacities. However, it may occur in areas with compacted soils or under extreme rainfall intensities. Quick routing of storm water into the subsurface zone may also occur through macropores, although their presence is more common in forest soils and likely to be of less significance in the gravel soils typical of the Ruataniwha Plains.

The Tukituki catchment is one of the driest in the North Island (HBRC, 1998) and all rivers crossing the Ruataniwha Plains are prone to drying out along their length in times of drought unless they are fed by springs. Many smaller headwater streams have little to no baseflow contribution between storm events, particularly during the drier summer months when losses to evaporation are high and catchment antecedent moisture levels are low. These first-order streams are best described as intermittent. River studies have pinpointed reaches of gaining and losing flow on a number of streams in the basin. These patterns show that the Waipawa and Tukituki Rivers lose water over much of their length to the subsurface system and to smaller adjacent streams. Losses generally decrease with decreasing flow (HBRC, 2003).

\subsection{Water quality and sediment generation}

Water quality in the streams of the Hawke's Bay region is quite variable, but hill country streams generally show better quality as compared to lowland streams (HBRC, 2009). This is likely due to the combined effects in lowland areas of more intensive land use and the accumulation of pollutants from upstream sources. Between 2004 and 2008, of the six Ruataniwha Plains streams under study, three streams showed improving water quality, one stream showed deterioration, and two streams showed severe deterioration (HBRC, 2009). The analysis was based 
on dissolved reactive phosphorus, dissolved inorganic nitrogen, water clarity, E.coli bacteria, macroinvertebrate communities, and periphyton biomass trends.

Water quality is likely to be lowest on small streams which are not capable of dilution (HBRC, 2003). In agricultural areas these are the streams that are least likely to be fenced from stock (leading to direct contamination and increased bank erosion from stock access) and least likely to have riparian planting (leading to higher loads of constituents reaching the stream directly and to higher water temperatures from lack of plant shading). As the Ruataniwha Plains has the greatest concentration of small streams in the Hawke's Bay region, these conditions may lead to significant cumulative effects in downstream reaches.

Declines in water quality in regional streams have been reported in relation to changes in river levels. At low flow levels in the summer, excessive periphyton growth in rivers has occurred as a result of nutrient input and/or macroinvertebrate degradation (HBRC, 2003). If periphyton biomass increases in a river, it leads to fluctuations in $\mathrm{DO}$ and $\mathrm{pH}$ levels, which in turn can affect fish species and macroinvertebrates, make water toxic to stock, and degrade aesthetic, recreational, and biodiversity values (Rutherford, 2009). The general degradation of water from upstream to downstream reaches in terms of nutrient enrichment and macroinvertebrate communities in the Tukituki River catchment has been noted by Ausseil (2008).

Although water quality on the Tukipo River in the upper reaches is generally good (according to State of Environment reporting standards), it is not as good as other upper catchment sites, and higher levels of dissolved reactive phosphorus (DRP) and soluble inorganic nitrogen (SIN), along with lower macroinvertebrate community index values were found between 1977 and 2008 (Ausseil, 2008). The SIN:DRP ratios indicate that the Tukipo River is under P-limited conditions. High DRP concentrations are generally found at low flows, suggesting possible point-source contamination or the contribution of P-rich groundwater to baseflow (Ausseil, 2008). Compared to other Ruataniwha Plains streams, the 
Tukipo River has the highest total organic carbon (TOC) and E.coli concentrations (Ausseil, 2008). The council is currently studying these issues and looking to implement remedial measures to improve water quality.

Along with nutrient levels, the volume of sediment transported within a river is sometimes used as an indication of water quality. In a given catchment, sources of sediment include erosion from hillslopes, gullies, and riverbanks. In the Ruataniwha Plains (as within much of New Zealand), steep, unforested hillslopes contribute the majority of sediment to streams. Almost all sediment generation occurs in the headwaters and virtually all sediment transport occurs during high flow events (Williams, 1985). Suspended solids (organic and inorganic) data for both the Tukipo River at SH50 and the Tukituki River at SH2 (Waipukurau) range from 0 to $440 \mathrm{mg} / \mathrm{L}$. The mean sediment transport rate for the Tukituki River is $0.0035 \mathrm{~m}^{3} / \mathrm{s}$ (Ludecke 1988).

Downstream of SH50, the Tukipo is essentially flowing as an undersized river in an old channel of the Tukituki River (Williams, 1985). In the late 1950s work was undertaken in response to aggradation occurring in the river, and the channel was enlarged to accommodate flood flows. Work on rivers in the region during this period included vegetation clearing of the river bed, gravel extraction, channel straightening, riparian planting, and riparian zone fencing to exclude stock from streams. The section of the Tukipo River downstream of SH50 was lightly cleared of instream vegetation and the riparian zone was fenced and planted. Gravel extraction from the Tukipo River between 1977 and 1986 averaged $1728 \mathrm{~m}^{3}$ per year (Ludecke, 1988). For the entire Tukituki catchment, $234,000 \mathrm{~m}^{3}$ of gravel were removed annually (for the same time period) from 8 streams and rivers in the catchment. Consents for gravel extraction are given annually based on extractors' requirements and the end use of the gravel, while considering effects of extraction on the river channel. The rate of extraction is not to exceed the rate of natural supply (HBRC, 2006a). 


\subsection{Land Use}

Land use in the Ruataniwha Plains consists primarily of arable cropping and pasture (sheep, beef, dairy, and deer). Pasture cover is more prevalent in the rolling uplands where poorer quality soil and access issues exist for cropping and other more intensive agricultural activities. In 2006, the Ruataniwha Plains catchment had 3500 ha of irrigated land, with a stated further potential of 35,100 ha available for irrigation (HBRC, 2006b).

Land use intensification for the Hawke's Bay region in recent years has mostly occurred on the Ruataniwha and inland Heretaunga Plains (HBRC, 2009). Since 2002, cropping area in the Hawke's Bay region has expanded by $82 \%$ and dairying by $22 \%$ (HBRC, 2009). In the Ruataniwha Plains area, there were 41 consents for the discharge of dairy effluent in 2009; seventeen of these consents were granted in the 7 years between 1999 and 2006, and the remaining 25 were granted in the following 2 years (2007 to 2009). In a survey of 42 farmers in the Ruataniwha Plains region regarding their likely future land use change, most indicated a move towards cropping, with dairying placing second (Benson, 2010).

Hawke's Bay Regional Council is presently considering water storage options in the Ruataniwha Plains area to allow for more irrigation and land use intensification in the future (discussed in more detail in Section 3.8). It is likely that future land intensification in the region will have effects similar to those resulting from intensification in other parts of the country. Both cropping and dairying will require further access to water resources, and higher stocking rates will result in increased soil erosion and land degradation, and a degradation of water quality in the streams and rivers of the region. 


\subsection{Water Use}

Hawke’s Bay Regional Council does not require consent for surface or groundwater takes for stock or domestic purposes, although consent is needed for water takes used for irrigation, industrial use, public water supply, and stock water races (HBRC, 2003). As of 2002, there were 150 consented water abstractions (surface and groundwater) in the Ruataniwha Plains area, equating to a total allocated flow of $4655 \mathrm{~L} / \mathrm{s}$ (HBRC, 2003). In the Ruataniwha Plains area, surface water is currently over-allocated and there is a moratorium placed on groundwater takes, until the full extent of the groundwater aquifers and resources are known.

Surface water consents are given on a first-up first-served approach and water volumes are allocated based on set volumes for each stream management zone over and above minimum flow levels (HBRC, 2003). Minimum flow levels were set in 1998 for all rivers and major streams in the Hawke's Bay region. These levels were determined by the IFIM method (Instream Flow Incremental Methodology; Bovee and Cochnauer, 1977), which bases minimum flow levels on the habitat requirements of a number of aquatic species. Allocation levels are placed above minimum flow levels, which have been set to the seven day averaged flow that is exceeded $95 \%$ of the time during the summer irrigation season (7-day Q95) (HBRC, 2003). Streams are placed on allocation warnings if stream levels fall close to these minimum flow levels. The exact timing of a warning is based on the specific characteristics of the river, flow recession values, and forecasted storm events. Abstraction bans are placed on the stream when the low flow level is reached, at which time all water permit holders must stop abstractions. Water users are warned by phone or email approximately 48 hours in advance of a likely ban. There is no low flow restriction placed on groundwater abstraction. 
The minimum flow level on the Tukituki River (at Waipukurau) is set at $1600 \mathrm{~L} / \mathrm{s}$, which represents a total daily flow of $138 \mathrm{ML}$. Based on available mean daily flow data, this level has never been reached, although bans have been placed on the river for a total of 22 days between 1994 and 2009. The minimum flow level on the Tukipo River (at SH50) was initially set at $110 \mathrm{~L} / \mathrm{s}$, but was increased in 1998 to $150 \mathrm{~L} / \mathrm{s}$ after the new low flow assessment method was implemented. This level represents a total daily flow of $13 \mathrm{ML}$. When the minimum flow level was changed in 1998, this effectively stopped any further allocation of water on the Tukipo River. An analysis of mean daily flow on the Tukipo River shows that these low flow levels have been reached approximately $5 \%$ of the time over the period of record (30 years). The majority (91\%) of minimum flow levels were reached in January, February, March, and April. Bans have been placed on the river for a total of 91 days between 1994 and 2009. As the lower reaches of the Tukipo River and the adjacent Maraketu River contribute baseflow to the Tukituki River, any decrease to their flow volumes due to climate change and/or further water takes will potentially have significant effects further downstream.

There currently is no maximum abstraction volume set for groundwater in the Hawke’s Bay (HBRC, 2006b). Permitted irrigation withdrawals from groundwater sources increased by 400\% between 1991 and 2001, with pumping volumes increasing by 10 million $\mathrm{m}^{3}$ per decade. Groundwater takes are expected to increase, particularly with the continued expansion of dairy and irrigated cropping in the area (Luba, 2001). Using data from the 21 monitored groundwater wells in the area, estimates suggest that only $32 \%$ of consented volumes are currently being used (HBRC, 2003). This is a lower figure than the 45\% estimated for the Upper Tukipo basin based on user surveys in 1997 (HBRC, 1998). As of yet, the council has no real knowledge of sustainable yields or volumes of allocation for these aquifers (HBRC, 2006b). They have only recently 
required takes from all consented bores to be metered (HBRC, 2009), so it is likely that sustainable volumes of withdrawal may be proposed in the future.

\subsection{Water Management on the Ruataniwha Plains}

With climate change predictions suggesting lower annual precipitation volumes and an increase in the frequency of drought, pressure on available water resources will likely be higher in the future. In the Hawke's Bay region, the predicted shift to drier winter conditions and slightly wetter summers may lessen the frequency of summer low flow bans. However, the timing of rainfall events will add complexity to expected changes as fewer rainfall events of greater intensity are predicted. This will influence the timing and magnitude of stormflow contributions to the stream, in turn impacting rates of sediment erosion, sediment transfer, and the addition of nutrients to the stream system. The expected increase in the frequency of summer droughts may increase the volume of sediment available for erosion during the infrequent summer rainfall events and the first large storm events of the autumn. These effects may be minimised with techniques designed to trap sediment, including riparian planting and the positioning of farm ponds further downstream in the catchment. The larger regional impact of climate change will likely include an increase in farm dam construction as farmers attempt to further their water security options. Current regional plans in the Ruataniwha Plains area are focused on furthering economic growth through agricultural intensification, while concurrently increasing water security. With surface water resources completely allocated and a moratorium placed on further groundwater takes pending more research, the council is considering alternative water supply sources in the Ruataniwha Plains area.

An initial study into the possibility of groundwater providing all of the predicted future pasture irrigation needs in the Ruataniwha Plains was completed (HBRC, 
2003). The model predicted that if $80 \%$ of the area $(35,100 \mathrm{ha})$ was irrigated for rotational cropping, a volume of 190 million $\mathrm{m}^{3}(190,000 \mathrm{ML})$ of groundwater would be required to meet demand in $90 \%$ of years (HBRC, 2003). The development of this potential irrigable land equates to an estimated generation of $\$ 116$ million of farm gate GDP per annum (HBRC, 2006b), but would also result in a maximum $5 \mathrm{~m}$ drawdown of groundwater in the summer, higher nitrate concentration inputs to streams, and a 10\% decrease in average annual surface water outflow from the basin, with a maximum decrease of $25 \%$ for summer low flows (HBRC, 2003).

An alternate investigation to address future water needs in the Ruataniwha Plains region involved a number of onstream and offstream water storages based on an irrigated demand of 22,500 ha, with a total storage volume of 90 million $\mathrm{m}^{3}$ (90,000 ML). A pre-assessment of the potential for a maximum of six water storage structures (between 9000 and 30,000 ML) for water supply and irrigation was completed by Tonkin \& Taylor at the request of Hawke's Bay Regional Council (Tonkin and Taylor, 2009). Proposed storage locations included dams on smaller tributary streams in the region as well as offstream storages which would be filled from nearby rivers during winter high flows. Offstream storages are seen as having a lower environmental cost, although the filling period may remove the river's peak flushing flows which are necessary for the maintenance of channel form. The fully developed scheme was estimated to abstract less than $6 \%$ of the annual river flow leaving the Ruataniwha Plains, assuming an irrigation return of 20\% (Tonkin and Taylor, 2009).

More recently, the council has focused on two new potential dam sites, which would dam the Makaroro Stream and Makaretu Stream, with reservoirs of approximately 50,000 ML and 25,000 ML respectively. These large dams would provide the same amount of irrigation capacity (22,500 ha) and may have power generation potential. Feasibility studies for the two sites are underway and will likely be completed by the end of 2012 (HBRC, 2011). Four of the proposed dam 
sites from the previous investigation are being considered as backup sites in case either or both of the large dams are deemed nonfeasible (HBRC, 2011).

Water storage on the Ruataniwha Plains, and elsewhere in New Zealand, is seen as necessary for regional growth and is supported by Federated Farmers as a 'magic bullet' for water security (Federated Farmers, 2008). However, concerns regarding the potential environmental effects of both large and small dams have been raised by others, including Fish and Game New Zealand (Fish and Game NZ, 2009). Fish and Game New Zealand are not opposed to dams per se; their main concern regards the proper pre-construction assessment of the dams in order to minimise any downstream impacts on flow regime and habitat.

However, even if these large water storages are built in the Ruataniwha Plains, it is likely that farmers will continue to build small storages (both onstream and offstream) to increase on-farm water options and water security. These small storages will continue to have additional impacts on water quantity, water quality, sediment transfer, and channel morphology of streams in the region. 



\section{Field Study}

This chapter presents the results of the paired catchment field-based study. The purpose of this investigation is to compare an unregulated system with a regulated system in detail through measures of hydrology, water quality, and channel sediment and morphology. Although studies have been completed on the effects of small dams, these have largely been theoretically based (see review in Chapter 2); this is the first comprehensive field-based study on the physical effects of small dams in New Zealand.

The unregulated and regulated catchments under study are located adjacent to each other, and the streams within each catchment are first order tributaries of the Tukipo River. Both catchments are small $\left(1.5 \mathrm{~km}^{2}\right.$ and $0.7 \mathrm{~km}^{2}$ respectively) and both have an intermittent stream which flows from the top of the catchment near State Highway 50 (SH50) and drains into the Tukipo River (Figure 4.1). Both the unregulated and regulated streams are intermittent with more continuous flow occurring during the wetter months of winter and spring (June until November). At times of low antecedent wetness, flow occurs only in response to large storm events. Baseflow from groundwater is not a large component of flow and is active primarily under conditions of high antecedent wetness. The two catchments and their streams will be referred to as 'unregulated' (northern catchment) and 'regulated' (southern catchment) for the purposes of this research.

The regulated stream has three small ponds constructed along its length, referred to as Ponds A, B and C from upstream to downstream (Figure 4.1). Based on historical aerial photographs, estimates on the time of pond construction were made. The upstream pond (Pond A) was created prior to 1953 when a farm track was built and the culvert under the track was placed higher than normal streamflow levels. Water accumulates behind the culvert to a depth of 


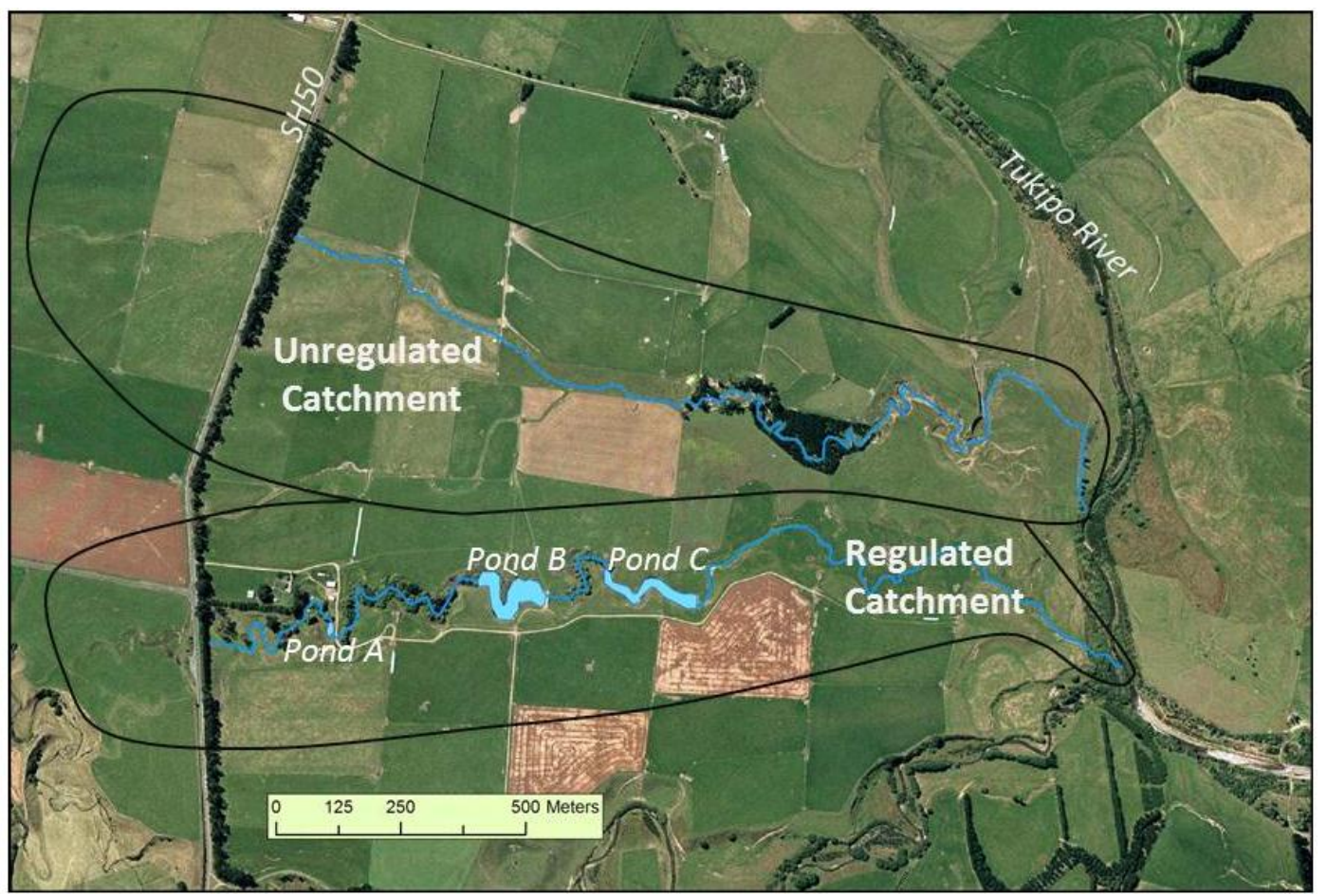

Figure 4.1: Map showing location of paired study catchments including streams and ponds.

approximately $0.5 \mathrm{~m}$ until it reaches the level of the culvert and flows

downstream. The estimated maximum pond volume is 0.6 ML. Pond B and Pond

$\mathrm{C}$ were created by earthen dams approximately $3 \mathrm{~m}$ in height with culverts

placed near the top of each dam to accommodate outflow (Figure 4.2). These are

estimated to have been constructed around 1970. Estimated maximum storage

volumes are $7 \mathrm{ML}$ for Pond B and 4 ML for Pond C.

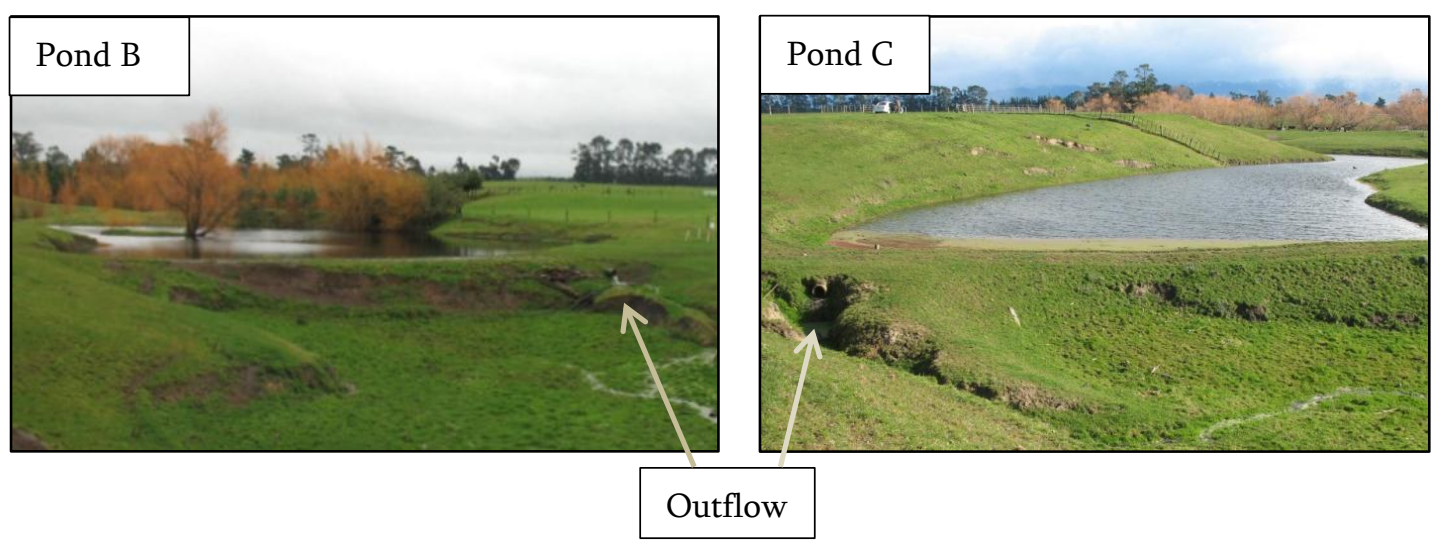

Figure 4.2: Photos of Pond B and Pond C. Dam height is approximately $3 \mathrm{~m}$ in both photos. The locations of the outflow culverts are indicated. 
Paired catchment studies are used to directly compare processes and responses between catchments under pre-treatment and post-treatment applications (e.g. Brown et al., 2005; Brooks et al., 2003). Both catchments are studied for a period of time in the pre-treatment period, followed by the treatment being applied to one of the catchments. The post-treatment response in the treated catchment is then compared to the 'normal' response of the untreated catchment. This approach is most typically applied to land use investigations; for example, in the determination of the effects of logging on catchment hydrologic response (e.g. Bowling et al., 2000). In the current study, it was not possible to compare the two catchments through pre-treatment and post-treatment periods. As an alternative, two similar catchments were chosen in order to directly compare the unregulated and regulated catchment systems. If the catchments are found to be sufficiently equal in aspects of geology, soil, climate, and land use, the differences between the two should be related to the presence of dams in the regulated catchment. Therefore, it is important that catchment variables between the two are deemed equivalent before any further investigation into the influence of farm dams is made.

In comparing climate patterns between the two catchments, data from nearby climate stations were compared to climate data collected at the study catchment. The Tukipo River gauging site is located $1 \mathrm{~km}$ to the north of the unregulated catchment at the SH50 bridge, where continuous streamflow, daily precipitation, and quarterly water quality data are collected by Hawke’s Bay Regional Council. The collected precipitation data were found to correlate strongly to the timing and volume of precipitation data collected at the field climate station (discussed further in Section 4.1.1). Other climate variables (e.g. air temperature, evaporation) were also found to correlate to regional climate patterns (using data from the Ongaonga climate station), suggesting that a similarity in climate between the two field catchments can be assumed. 
The two catchments also have similar geology and soil patterns, as found through a review of regional studies and maps of the area (HBRC, 2003; Griffiths, 2004). There is a mapped fault which runs across both streams in their upper catchments. A fault might create a difference in local erosion rates, but as it is upstream of all three dams, it is likely that the presence of the fault will affect both catchments similarly.

Current land use is stock (sheep and beef in the regulated catchment, and sheep and deer in the unregulated catchment) along with a small amount of cropping at both farms. The intensity of land use in both catchments is similar, although the regulated catchment had a shift towards slightly higher stocking rates after it changed ownership in January, 2009. It is assumed that this increase does not have any great effect on processes operating within the catchment, as the overall stocking rates in both catchments are fairly low.

The main differences between the two catchments are catchment size and the morphological history of the streams. Because the unregulated catchment is close to twice the size of the regulated catchment, all results from the hydrological analyses are presented using unit area values. The differences in catchment size are also considered in the discussion of morphological characteristics and relative rates of channel change.

In terms of morphological history, the regulated stream was once part of a larger meandering stream, but its head was truncated by the Mangatewai Stream (located to the south) at some point in the past. Thereafter, a large decrease in flow volume occurred and the wide channel meanders were subject to sediment infilling. The present stream is underfit within this old channel and has a primarily aggradational regime. The stream in the unregulated catchment is currently incising throughout its length. In the upper catchment there is evidence of headward erosion and channel deepening. In the lower catchment, just upstream of the floodplain, there is a section (approximately $200 \mathrm{~m}$ in length) where the stream has previously experienced downcutting into the terrace 
gravels, leaving steep terrace scarps on either side of the valley. This period of downcutting might have occurred as a result of rapid uplift, or as a result of higher streamflow volumes at some point in the past. In these reaches, the unregulated stream, like that of the regulated stream, is underfit within these wider meander incisions.

In terms of morphological history, the beheading of the regulated stream has left a much wider valley into which the present stream is underfit. The unregulated stream is also currently underfit within wider meander loops from a previous regime, but the valley itself is not as wide as compared to the regulated catchment. In the interpretation of morphological observations within the present study, the difference in channel morphology between the two catchments will need to be considered. This is investigated further in the discussion of sedimentologic and morphologic observations (Section 4.2.3). In all other respects the two catchments are similar, and it is concluded that a paired catchment comparison in the present study is valid.

\subsection{Data collection}

Field data were collected from June 1, 2008 to October 1, 2009, with subsequent analyses based on a hydrologic year of August 1, 2008 to August 1, 2009. This period represents a 'pond full' condition from one year to the next. Some parameters at the study site were monitored continuously using dataloggers, while other data were collected during regular field visits to the site (16 visits in total, approximately once a month). The study was carried out during a period of below average precipitation ( $27 \%$ below the 20 -year annual average measured at the Tukipo SH50 gauging site) with spring and autumn showing the greatest departure from precipitation norms (Figure 4.3). Streamflow was also below average (24\% below the 30 -year annual average measured at the Tukipo SH50 gauging site) with flow volumes below normal from spring through to the beginning of winter (Figure 4.4). Temperatures were average (within $0.1^{\circ} \mathrm{C}$ of the 
10-year annual average measured at the Ongaonga climate station). The different periods used for these statistics (i.e. 10-year to 30-year averages) are a reflection of the available data.
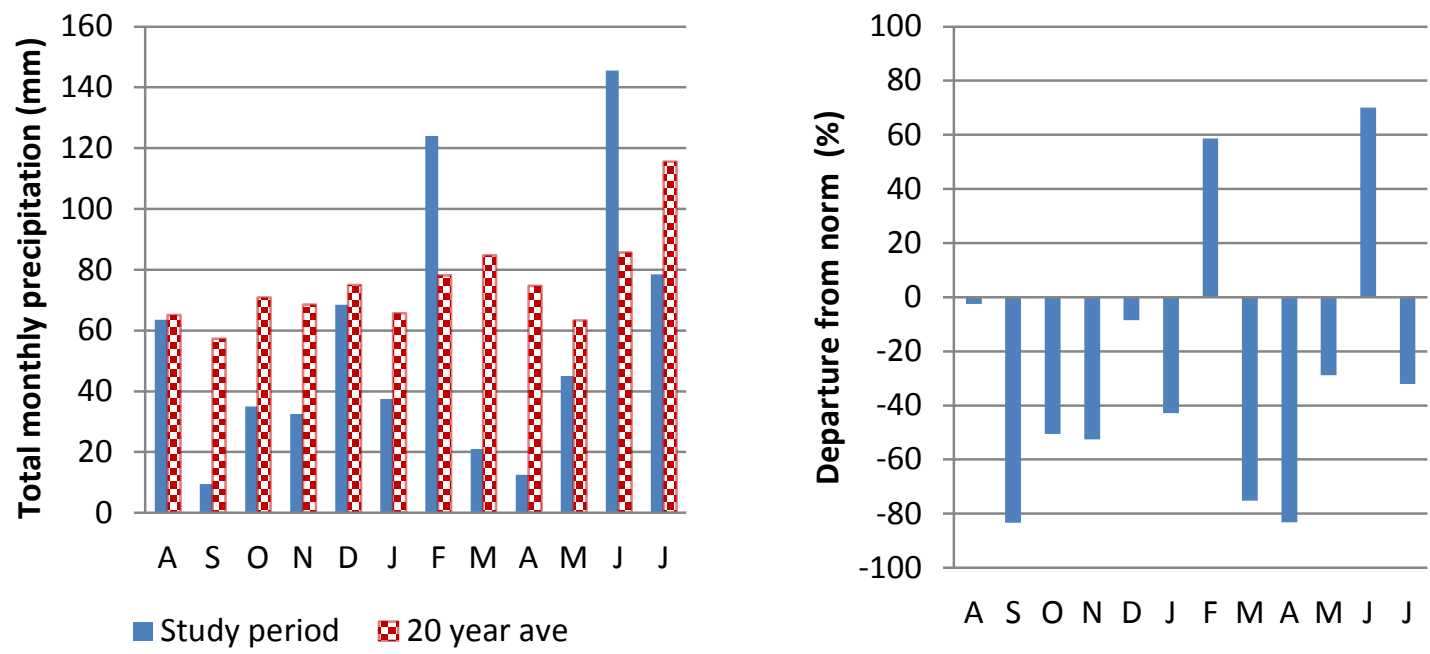

Figure 4.3: A. Tukipo SH50 data comparing 20-year average monthly precipitation totals to total monthly precipitation during the study period (Aug. 1, 2008 - Aug. 1, 2009) B. Tukipo SH50 data showing departures from monthly precipitation norms during the study period.

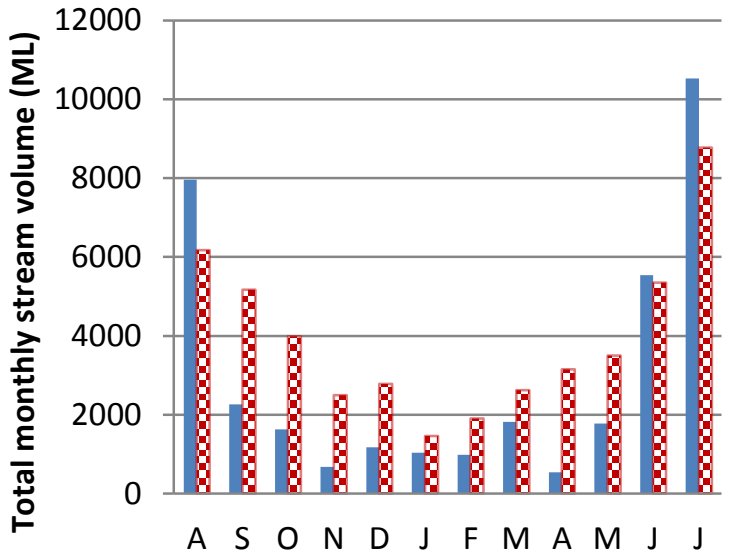

Study period $\quad 30$ year ave

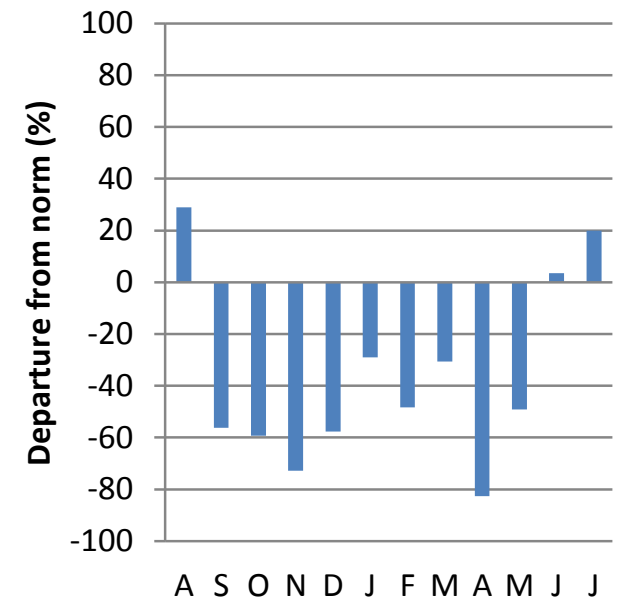

A SONDJFMAMJ J

Figure 4.4: A. Tukipo SH50 data comparing Tukipo River 30-year average monthly streamflow volume to total monthly streamflow volume during the study period (Aug.1, 2008 - Aug.1, 2009) B. Tukipo SH50 data showing departures from monthly streamflow norms during the same period. 
Monthly precipitation totals were variable throughout the study period. The majority of rainfall events were small, with total daily rainfall $<5 \mathrm{~mm}$ occurring on $78 \%$ of all days with measurable rainfall. However, in terms of total rainfall volume, large infrequent storms were more significant, with $17 \%$ of annual precipitation accounted for by only 7 days of storm rainfall.

\subsubsection{Climate}

A small climate station $\left(\mathrm{HOBO}^{\circledR}\right.$ microstation) was installed next to Pond B for the duration of the study (Figure 4.5). An electric fence enclosed the climate station to keep stock away from equipment. Air temperature, dew point temperature, relative humidity, air pressure, wind speed, and precipitation were logged at 15 minute intervals. Temperature probes were shielded and placed at $2 \mathrm{~m}$ height. A standard Class A evaporation pan was installed on January 27, 2009 and pan water levels were logged at 15 minute intervals using an InSitu ${ }^{\circledR}$ LevelTROLL until May 5, 2009.

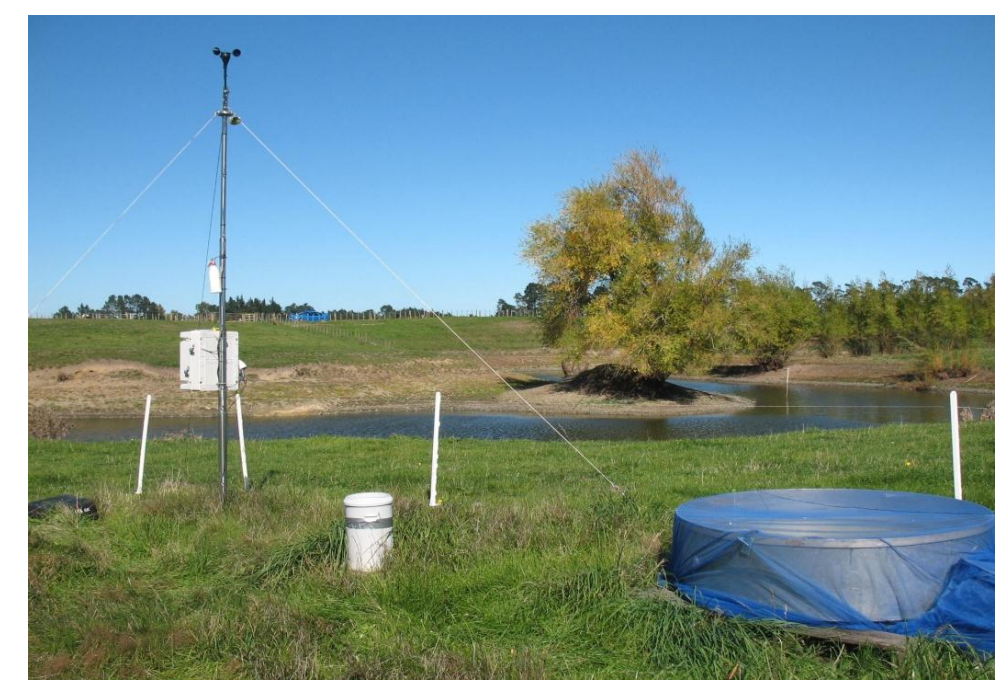

Figure 4.5: Climate station, tipping bucket rain gauge, evaporation pan next to Pond B.

Precipitation was measured with a tipping bucket rain gauge, and volumes were checked for accuracy using a standard graduated cylinder rain gauge. Missing precipitation values (due to tipping bucket malfunction) accounted for $12 \%$ of the total rainfall data collected (59 days in total) and occurred during December and January, a period of low rainfall as measured at the Tukipo SH50 gauging site. To 
infill these data gaps, a regression equation was established for the relationship between Pond B precipitation data and Tukipo SH50 precipitation data for the period June, 2008 to October, 2009 (Figure 4.6).

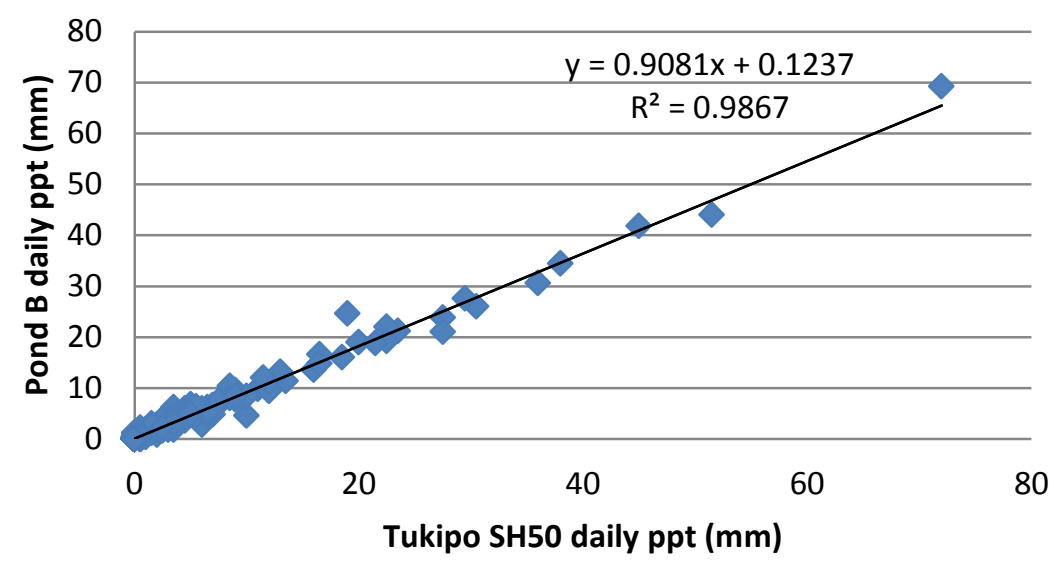

Figure 4.6: Relationship between precipitation values at Tukipo SH50 gauging site and Pond B climate station.

\subsubsection{Hydrology}

In-Situ ${ }^{\circledR}$ LevelTROLLS were used to measure stream water level at the unregulated and regulated stream catchment outlets, and the pond water level in Pond B. Calculated streamflow levels were used to assess the difference between the two catchments in terms of flow timing and total flow volume in response to storm events. Along with detailing the timing of pond emptying and filling, Pond B water levels were also used to estimate pond water losses to seepage and evaporation. Because the LevelTROLL pressure transducers are unvented, measured values represent the combined pressure of water and air. Therefore, a pre-processing step which subtracts air pressure (measured using an In-Situ ${ }^{\circledR}$ BaroTROLL at the Pond B climate station) from total measured pressure was first undertaken. The corrected pressures were then converted to equivalent water levels using a standard conversion factor.

According to instrument specifications, the LevelTROLL and the BaroTROLL have accuracies of $\pm 0.1 \%$ at $15^{\circ} \mathrm{C}$ and $\pm 0.2 \%$ across temperature ranges of $-5^{\circ} \mathrm{C}$ to $55^{\circ} \mathrm{C}$. When these accuracies are applied to average pressure readings from the 
field site over the period of study, an average combined water level accuracy of $\pm 21 \mathrm{~mm}$ is found. At the time of each field visit, water level measures were taken manually to ensure that measured pressures were within an acceptable tolerance. Streamflow volume was determined by converting stream stage to flow volume based on level-discharge relationships that were derived from discharge measurements taken during field visits. Discharge was measured at the outlets of the unregulated and regulated streams using a current meter (OSSPC1 current meter).

Pond volumes were calculated to determine the maximum volume of water storage in the regulated catchment. Water depth was measured at a number of points (between 24 and 50) in each pond. These surveys were taken when ponds were below maximum volume, so the height to full pond level was added to measured water depths. The area of each pond at maximum storage capacity was determined by digitising pond areas using available LiDAR data within a GIS platform.

\section{Streamflow}

Water level-discharge relationships were derived for the unregulated and regulated stream outlets (Figures 4.7, 4.8 respectively). A total of 5 current meter measurements were taken at the catchment outlet of the unregulated stream and 7 current meter measurements were taken at the outlet of the regulated stream. Depending on the level of flow at the time of measurement, the stream was divided into 3 to 5 vertical subsections, and velocity was measured at 0.6 of the total depth at each vertical subsection. For both streams, curves were developed in Excel using power relationships, as is normally expected for level-discharge relationships. After the relationships were derived, they were applied to measured water levels to determine flow volumes over the period of study. All discharge measurements were taken at low to medium flow stages, so the derived level-discharge relationships are most accurately applied to flow events within 
these ranges. In theory, the derived relationship should not be extended beyond measured discharge values, but in practice these relationships are often extrapolated $100 \%$ beyond the range of known measurements. To determine the reliability of flow stages outside the observed ranges, an assessment was made of the upper boundary of reliability as calculated from the derived level-discharge relationships, in order to determine whether or not it would be reasonable to extend the derived relationship beyond measured values.

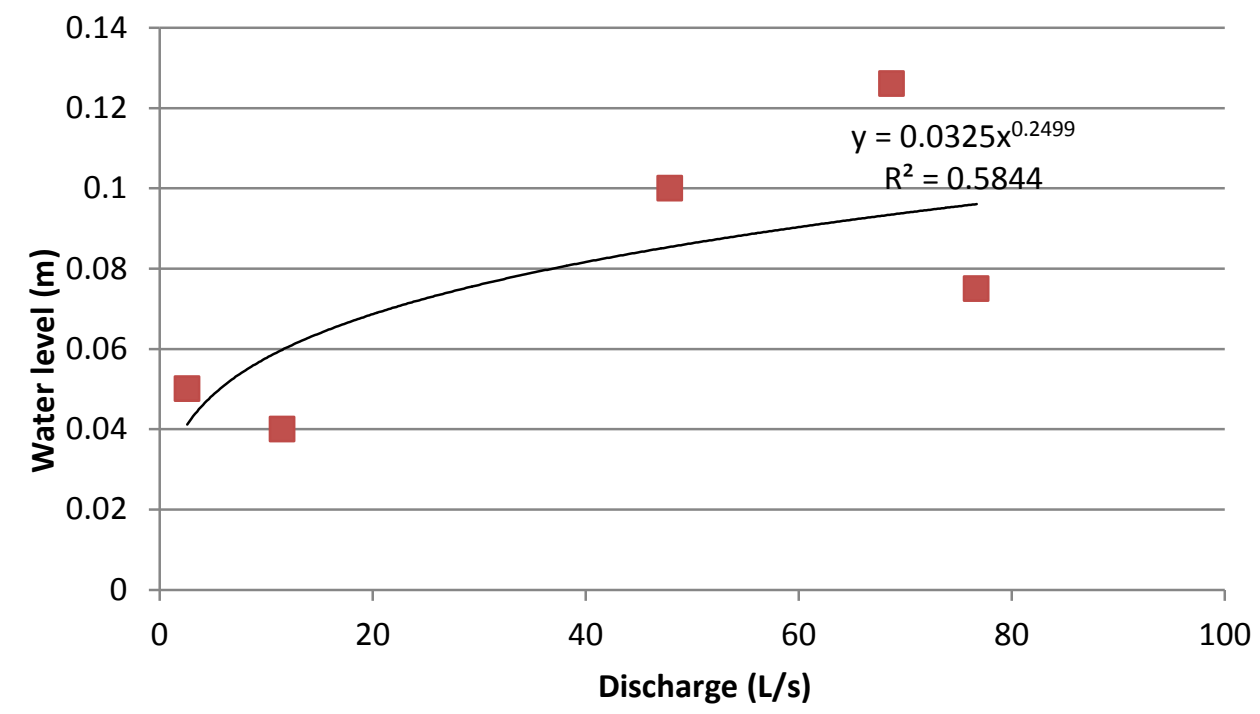

Figure 4.7: Level-discharge relationship for unregulated stream.

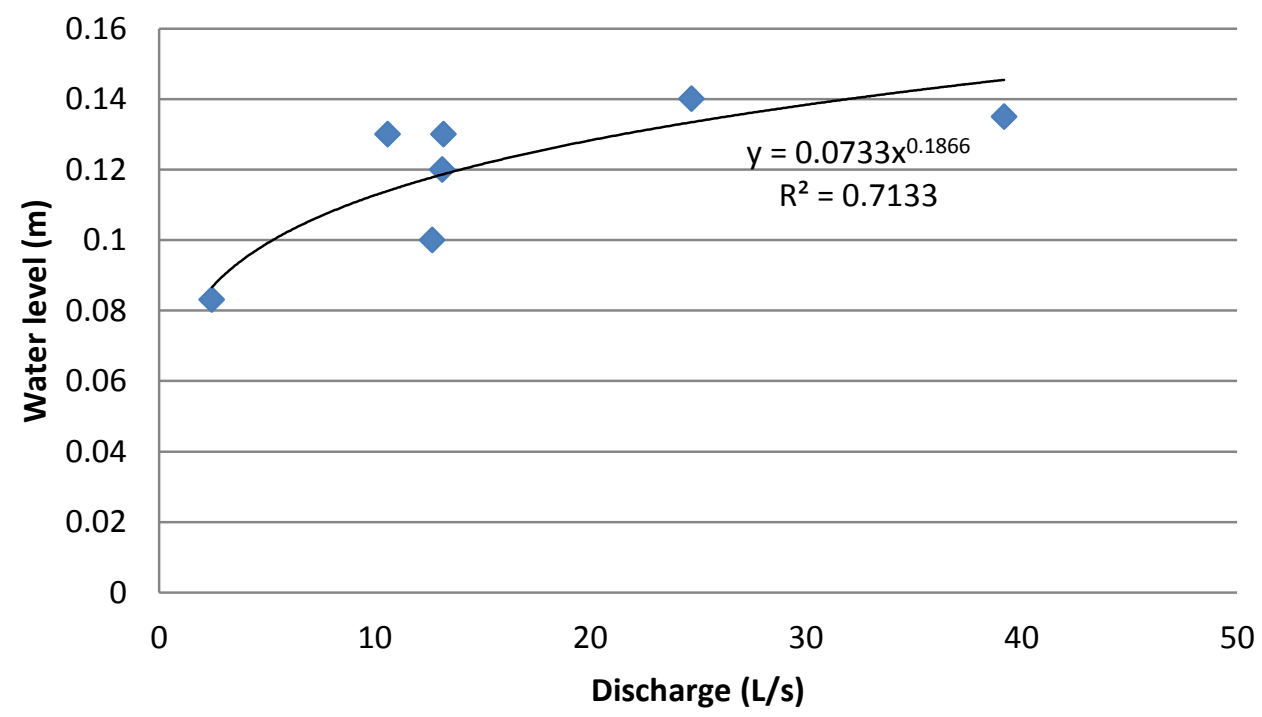

Figure 4.8: Level-discharge relationship for regulated stream. 
The slope-area method can be used to estimate discharge at channel bankfull levels. Bankfull discharge, calculated for both the unregulated and regulated streams, will then be used as the upper bound for the level-discharge relationship in order to test the reliability of the derived relationship. The formula is computed using the Manning formula:

$$
Q=\frac{A R^{2 / 3} s^{1 / 2}}{n}
$$

where $Q=$ bankfull discharge $\left(\mathrm{m}^{3} / \mathrm{s}\right) ; A=$ area of the channel at bankfull level $\left(\mathrm{m}^{2}\right) ; R=$ bankfull channel hydraulic radius $(\mathrm{m}) ; s=$ slope of the bankfull water surface (approximated by channel bed slope), and $n=$ Manning's roughness factor. Manning's $\mathrm{n}$ is estimated based on known channel bed characteristics. It is a difficult variable to estimate, as it decreases with increasing flow up to bankfull. Because actual bankfull conditions were never directly observed in the field, the estimated bankfull discharge values will only be used as a rough approximation of the maximum discharge that would be expected for the two streams.

The derived bankfull discharge for both streams at the catchment outlets is based on measured channel bankfull width and depth, derived channel bed slope (from Lidar data), and estimated Manning's n (from observed channel bed characteristics). In both channels under study, bed material is uniform and there are no bedforms or other structural bed features. Bankfull discharge at the catchment outlet is estimated at $642 \mathrm{~L} / \mathrm{s}$ for the unregulated stream and $105 \mathrm{~L} / \mathrm{s}$ for the regulated stream. Integrated for catchment size, these values become $428 \mathrm{~L} / \mathrm{s} / \mathrm{km}^{2}$ for the unregulated stream and $150 \mathrm{~L} / \mathrm{s} / \mathrm{km}^{2}$ for the regulated stream. These values are plotted in Figure 4.9 along with the derived level-discharge relationship for both streams.

Extrapolating the derived level-discharge relationship to incorporate the estimated bankfull discharge (as shown in Figure 4.9) shows general agreement in the range of measured values, with regulated stream values also corresponding 


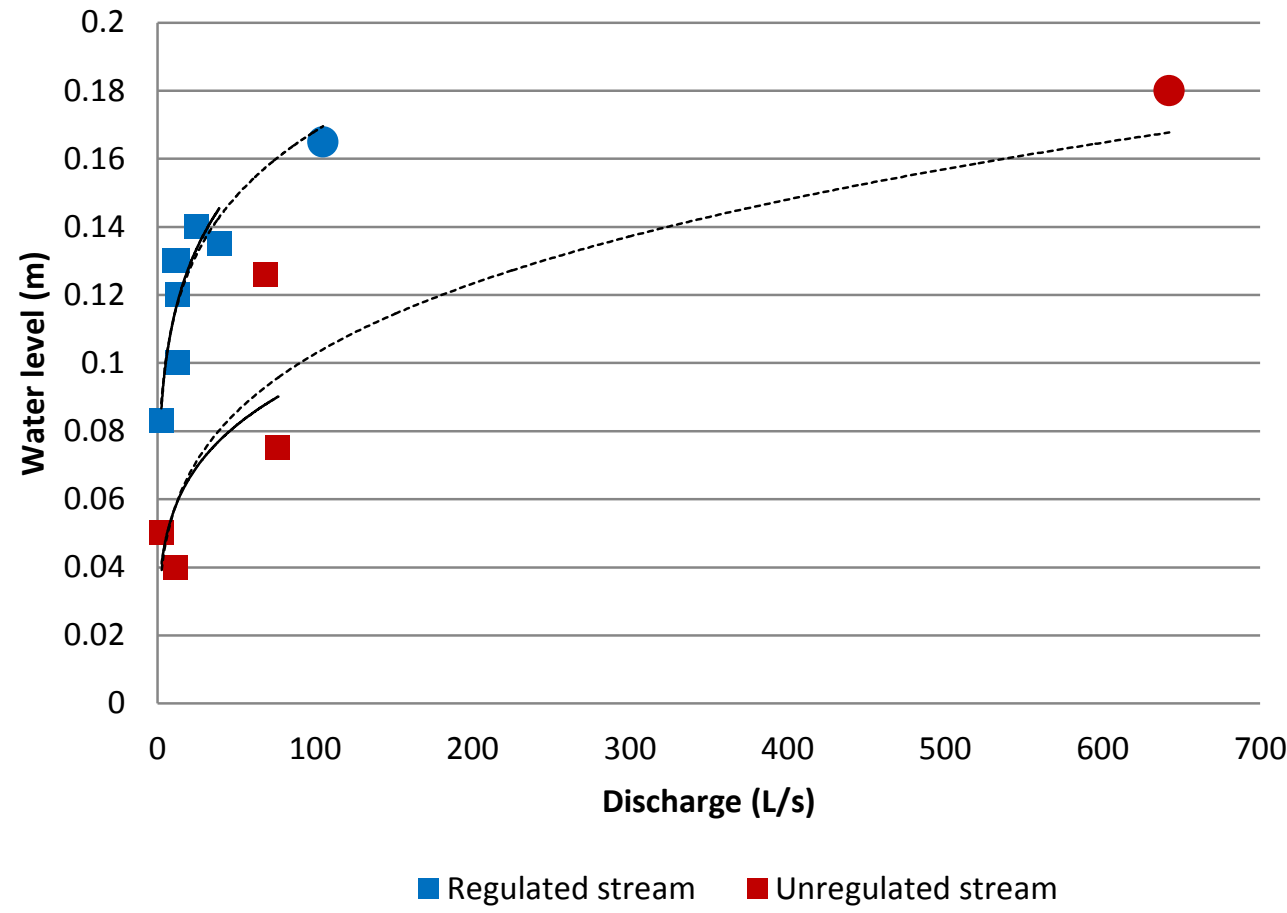

Figure 4.9: Derived level-discharge relationship (solid line) based on measured discharge (squares) for the unregulated and regulated streams, along with the new relationship (dashed line) based on estimated bankfull discharge (circles).

quite well in the higher discharge range beyond measured values. However, the relationship derived for the unregulated stream suggests that stream discharge is generally underestimated by the level-discharge relationship in the range beyond measured values. The relationship derived from bankfull values suggests that the level-discharge relationship derived from measured discharge values is reasonable. However, it should be noted that the bankfull discharge value is only a rough approximation of actual conditions and is subject to uncertainty, particularly in the estimation of Manning's n.

Another method of finding the outer bounds of reliability of the derived leveldischarge relationship is by calculating maximum velocities expected based on the Froude number, as it will rarely exceed unity in alluvial channels (Chorley and Carson, 1969). The Froude number $(F r)$ is a dimensionless value:

$$
F r=\frac{v}{\sqrt{g d}}
$$


where $v=$ stream velocity $(\mathrm{m} / \mathrm{s}), g=$ acceleration due to gravity $\left(\mathrm{m} / \mathrm{s}^{2}\right)$, and $d=$ channel depth (m). The Froude number was calculated for both the unregulated and regulated streams using known channel depths and velocities as calculated from discharge estimates at the 200\% level (using the level-discharge relationship). It was found in both cases that the Froude number was less than 1 (0.83 unregulated, 0.87 regulated catchment).

Because both tests of reliability suggest that the derived level-discharge relationship gives reasonable values for flow events outside of the measured range, the level-discharge relationship was extended to the $200 \%$ level and this level was used as the upper limit of reliable catchment discharge in all subsequent analyses. Only $0.5 \%$ of measured levels on the unregulated stream and $1.5 \%$ of measured levels on the regulated stream fall outside of this boundary of reliability. It should be noted that this extension of the level-discharge relationship will bring uncertainty into the derived flow volumes for the unregulated and regulated streams, and conclusions based on flow volumes derived from the extended relationship will be made with this uncertainty in mind.

\subsubsection{Water quality}

Water quality data were collected to identify general water quality characteristics in the two catchments under study. Water quality was measured using a TDS 90FLMV which collects instantaneous measures of $\mathrm{pH}$, dissolved oxygen (DO), total dissolved solids (TDS), electrical conductivity (EC), and water temperature. Field measurements of TDS are approximated based on electrical conductivity measurements (automatically corrected for temperature), meaning that trends for TDS and EC in the study catchments will be the same. Because DO fluctuates throughout the day, water quality measures were always taken at the same general time (mid-morning). Measures were taken within the three ponds and at their outlets, as well as at the catchment outlets of both the unregulated and 
regulated streams at the time of each field visit. Similar to the circumstances surrounding discharge measurements, water quality measures were also taken at low to medium flow stages. Because times of low to no flow occurred in both streams, the total number of measures taken over the period of study varies between four (unregulated stream outlet) and eleven (Ponds B and C). Water quality data from the Tukipo SH50 gauging site are also available from the Hawke's Bay Regional Council. These data are collected four times a year for State of the Environment reporting and were used in the present study to provide a comparison to values found at the study catchments.

\subsubsection{Sediment and morphology}

Sedimentological and morphological analyses were undertaken to characterise the transfer of sediment along the unregulated and regulated streams and to infer any differences between the two systems that have occurred in the postregulation period. Sedimentological analyses were designed to determine the quantity of suspended material moving through the two streams (suspended solids analysis), the nature of bed material (channel bed sediment analysis), and change in the depositional environment through time on the regulated stream (sediment size analysis from sediment pits). Morphological analyses were designed to compare the two stream systems, with channel width, sinuosity, and longitudinal profile measured.

Stream concentrations of suspended solids (total suspended organic and inorganic material) were measured by grab samples collected at the outflow of each of the three ponds and in mid-channel locations at the outlets of both the unregulated and regulated streams during field visits (at the same time discharge measurements were taken). This method was determined to be acceptable by Edwards and Glysson (1999) who suggest that collection using an open bottle is sufficient if stream velocity is low and no sand is being transported. In the lab, samples were weighed, filtered ( $25 \mu \mathrm{m}$ filters), oven dried for 72 hours at $40^{\circ} \mathrm{C}$, 
and re-weighed to complete the suspended solid concentration calculations. As total suspended solid concentrations were found to be low, no separation of organic and inorganic material was completed. Over the period of study, a total of 4 unregulated stream samples, 6 regulated stream samples, and 17 pond outlet samples (5 to 6 samples from each pond) were collected and analysed.

To further investigate the nature of sediment transport in the two streams, sediment samples were taken in the summer from the surface of the dry channel bed at various locations along both streams (sampled locations shown in Figure 4.10). Sediment calibre was determined from these samples using calliper, sieve and/or laser diffraction methods depending on the size and range of the sediment grains comprising each sample. Dry sieving is an appropriate method for sediment sizes between $4 \varphi$ and $-4 \varphi$ and was used for samples in the coarser size ranges. Sediment coarser than $-4 \varphi$ after sieving was measured using callipers (Baxis measured). Fine material was analysed using the laser diffraction method (lasersizer), which is recommended for sediment finer than $-1 \varphi$. The lasersizer uses light scattering principles to measure particle size distributions. Particle size

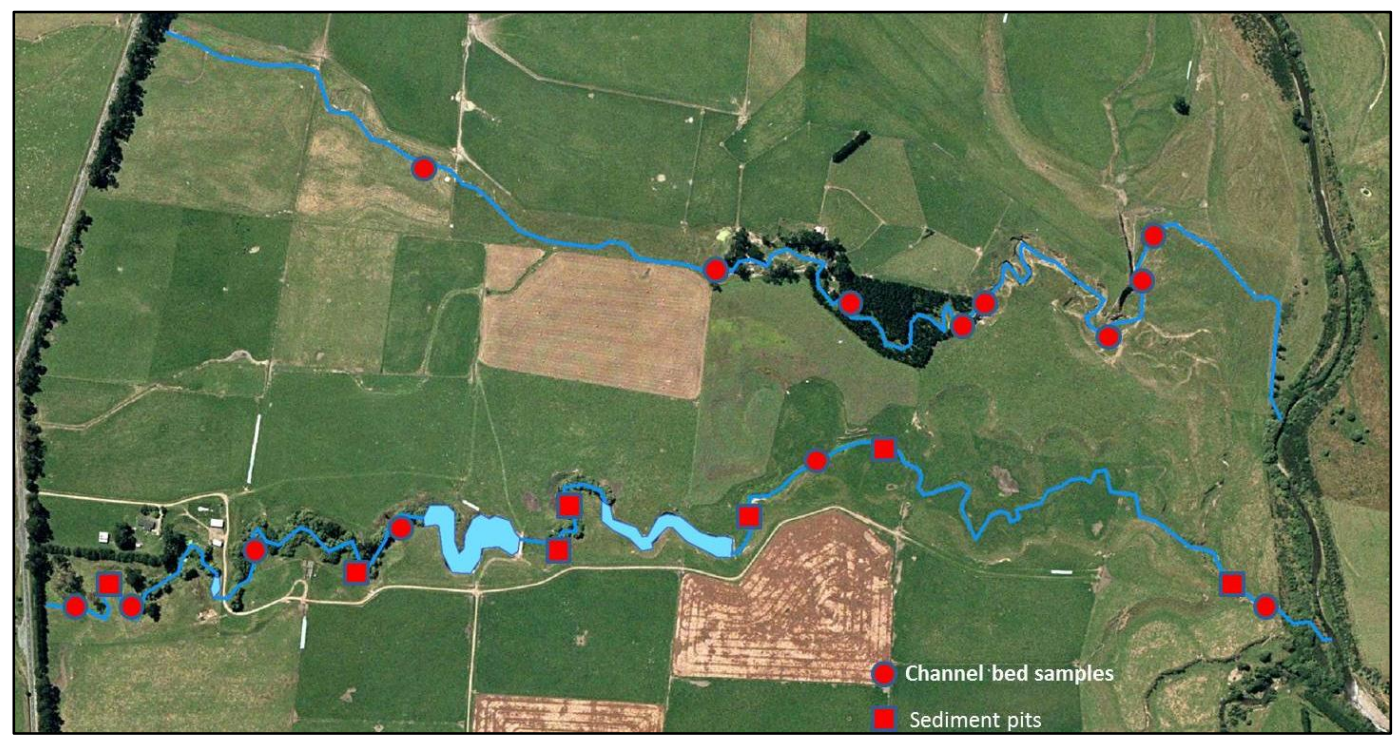

Figure 4.10: Locations of sediment collection sites (channel bed sediment and sediment pit locations) in the paired catchments. 
is related to the angle of diffraction (scatter) from a laser beam passing through a dispersion of the sediment sample. Standard procedural techniques were followed for all analyses with results based on the Folk and Ward method (Folk and Ward, 1957).

To determine if a change in depositional environment has occurred over time, sediment pits were dug at various locations on the regulated channel (sampled locations are shown in Figure 4.10). Pits were dug to a depth where fine gravels were encountered (the overlying material being much finer), which likely represents some prior regime change. Depending on the location of the pit, this level was reached at a depth between 0.20 and $0.93 \mathrm{~m}$, with depth to gravel decreasing in a downstream direction. A total of 10 sediment pits were dug and sediment samples were collected at various depths for particle size analysis. One sediment core was extracted from Pond C using a PVC tube pounded into the dry bed of the pond and then removed by hand. It was anticipated that the core might reveal some fining-up sequences related to seasonal flow regime changes. However, as no structure or variability within the core was found, no further core samples were collected for analysis.

To test for any morphological changes expected with regulation, channel widths were measured along the length of both the unregulated and regulated channels. Channel depths were not evaluated as the channel bank was often indistinct at reach locations on the regulated stream. Channel sinuosity and the longitudinal profile of both the unregulated and regulated channels were assessed using LiDAR data and aerial photographs obtained from Hawke's Bay Regional Council. 


\subsection{Results}

\subsubsection{Hydrology}

During field visits, discharge measurements were taken at the outflow of each pond using a volumetric measurement technique (time taken to fill a container of known volume). Using these discharge measurements and those taken at the regulated stream outlet, an analysis of possible transmission loss on the regulated stream was made. Discharge measures were plotted (Figure 4.11) and reveal that, with one exception, discharge is observed to increase in a downstream direction. The expected downstream discharge was then estimated using the total annual flow volume expressed as a depth over the regulated catchment $(216 \mathrm{~mm})$ and multiplied by the upstream contributing area at each pond outflow location. Runoff derived in this manner is compared to observed discharge to see if any differences exist, which would be expected if transmission losses are significant. Overall, the measured discharge generally follows the trend of the expected

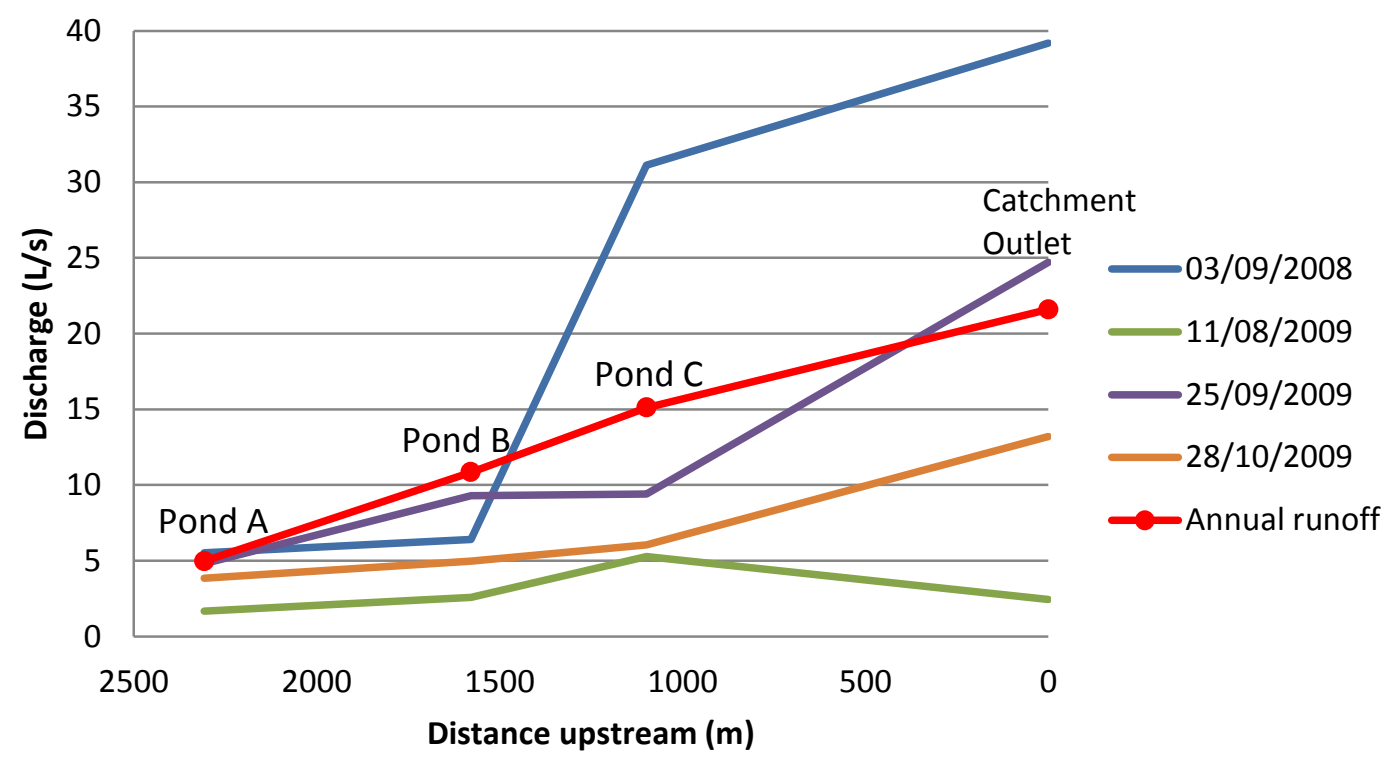

Figure 4.11: Regulated stream discharge measurements at various times showing a general increase in discharge downstream. The red line ('Annual runoff') is the calculated annual yield for each point in the catchment (considering upstream contributing area); annual values have been scaled for comparison purposes. 
downstream discharge (Figure 4.11, 'Annual runoff' line) and it is concluded that transmission loss is not significant on the regulated stream.

\section{Timing of flow}

A typical hydrograph for the unregulated and regulated streams is shown in Figure 4.12. All flow volumes are based on the derived level-discharge relationship, as described previously. Stream statistics including storm event response, baseflow index, and coefficient of variation of daily flow were calculated using the River Analysis Package (RAP), a statistical software program (Marsh et al., 2003). The unregulated stream responds quickly to storm events, reaching peak levels shortly after storm initiation, followed by a quick recession to low or no flow levels. Storm event response shows a mean rate of rise of
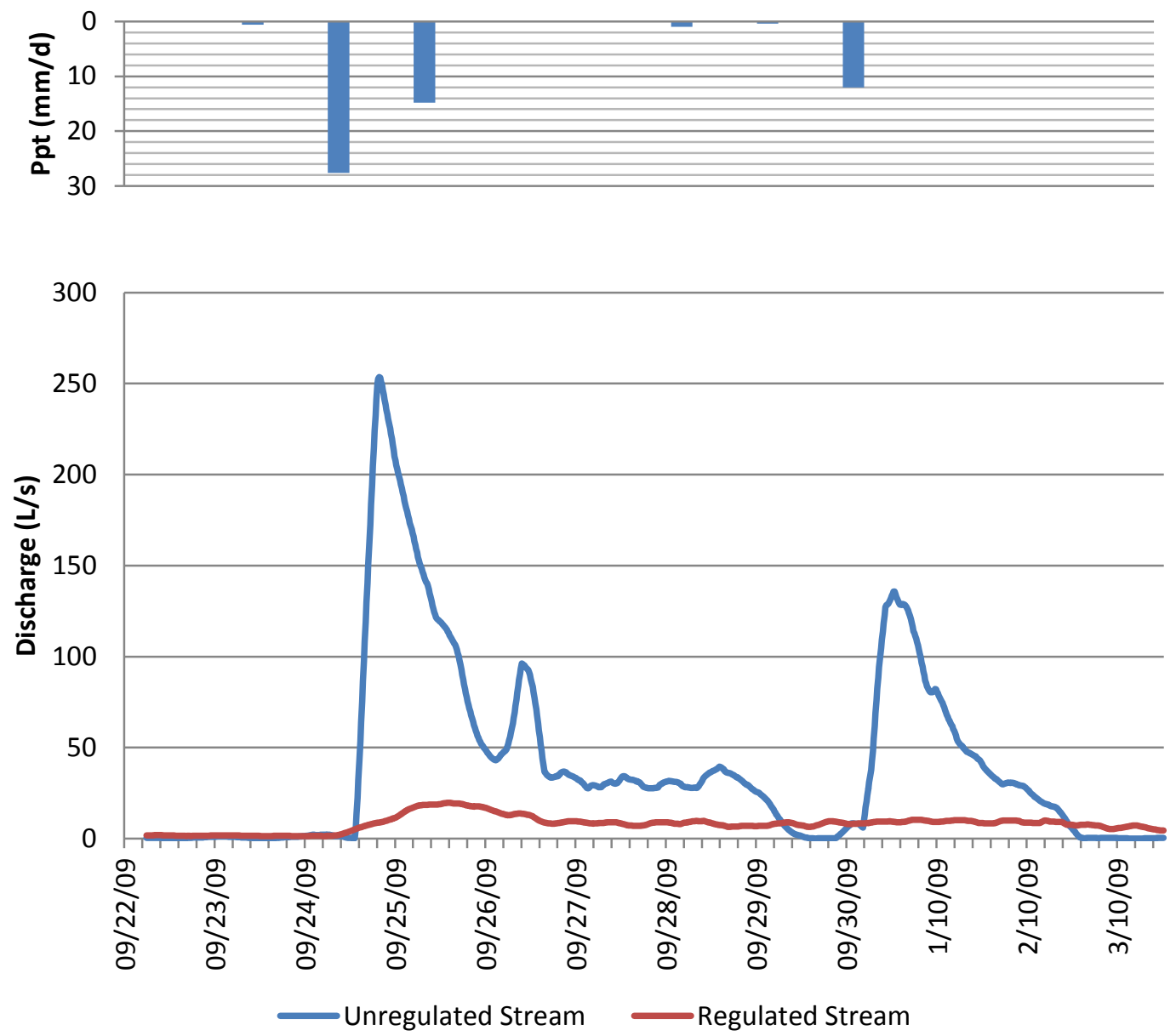

Figure 4.12: Typical streamflow hydrographs measured at the unregulated and regulated stream outlets for a storm event in early spring, 2009. 
$1.02 \mathrm{ML} / \mathrm{d} / \mathrm{km}^{2}$ and a mean rate of fall of $0.69 \mathrm{ML} / \mathrm{d} / \mathrm{km}^{2}$. At the unregulated stream outlet, baseflow was not continuous between most storm events throughout the winter (baseflow index $=0.17$; calculated in RAP using the 3 -way digital filter method of Grayson et al., 1996) and flow ceased completely in midSeptember, 2008 despite the continuation of storm events. Precipitation levels were $40 \%$ below the long-term average during the nine month period of no streamflow and it is likely that any precipitation falling during this time infiltrated directly into the soil and did not reach the stream channel as either stormflow or baseflow. After the dry summer period, flow began on June 28, 2009 when an extremely large storm event caused a rise in antecedent wetness levels within the catchment.

The timing of regulated streamflow was closely linked to water levels within the ponds, with the stream flowing continuously throughout the winter when ponds were full and overflowing. The rate of rise and fall of the regulated stream is lower than that of the unregulated stream, with average rates of $0.08 \mathrm{ML} / \mathrm{d} / \mathrm{km}^{2}$ (rise) and $0.13 \mathrm{ML} / \mathrm{d} / \mathrm{km}^{2}$ (fall). Flow on the regulated stream was less variable, with a coefficient of variation of daily flow equal to 2.6 as compared to 3.0 for the unregulated stream. The maximum flow event measured during the hydrologic year was 33\% lower on the regulated stream as compared to the unregulated stream and high flows (defined as flow exceeded 10\% of the time; $\mathrm{Q}_{10}$ ) were approximately $40 \%$ lower on the regulated stream as compared to the unregulated stream (both values have been integrated to account for differences in catchment size). The baseflow index measured at the regulated stream outlet was 0.20 , showing a slightly higher baseflow component for the regulated stream. When the unregulated stream stopped flowing in mid-September, 2008, flow on the regulated stream continued for 26 days until upstream pond levels dropped below the level of the outflow culverts. From this time, no flow occurred on the regulated stream until the ponds were full again in July, 2009. At this time, downstream flow was delayed by 5 days as compared to the unregulated stream 
response. This period of no flow when ponds were below full levels was expected and it is unlikely that the regulated stream would have any flow during this period even under higher levels of precipitation.

Out of a total of 365 days (Aug. 1, 2008 to Aug. 1, 2009), the outlet of the unregulated stream had 1216 hours of measurable flow, which equates to a total of 50.6 days ( $14 \%$ of annual total), while the outlet of the regulated stream had 2426 hours of measurable flow, equating to 101 days ( $28 \%$ of annual total). Days of no flow occurred in all 12 months on the unregulated stream and in 10 months on the regulated stream. There was no flow at either stream outlet from December, 2008 through May, 2009.

Lag time was calculated to determine the difference between the two catchments in terms of streamflow response to individual storm events. Lag time is the period between the time of peak storm rainfall and the time of peak runoff. Eleven storm events were analysed and it was found that in eight cases the unregulated stream had a shorter lag time in comparison to the regulated stream (Figure 4.13). The response of the regulated stream was often too small to distinguish, which is why only eleven storm events were analysed. Lag time on the unregulated stream

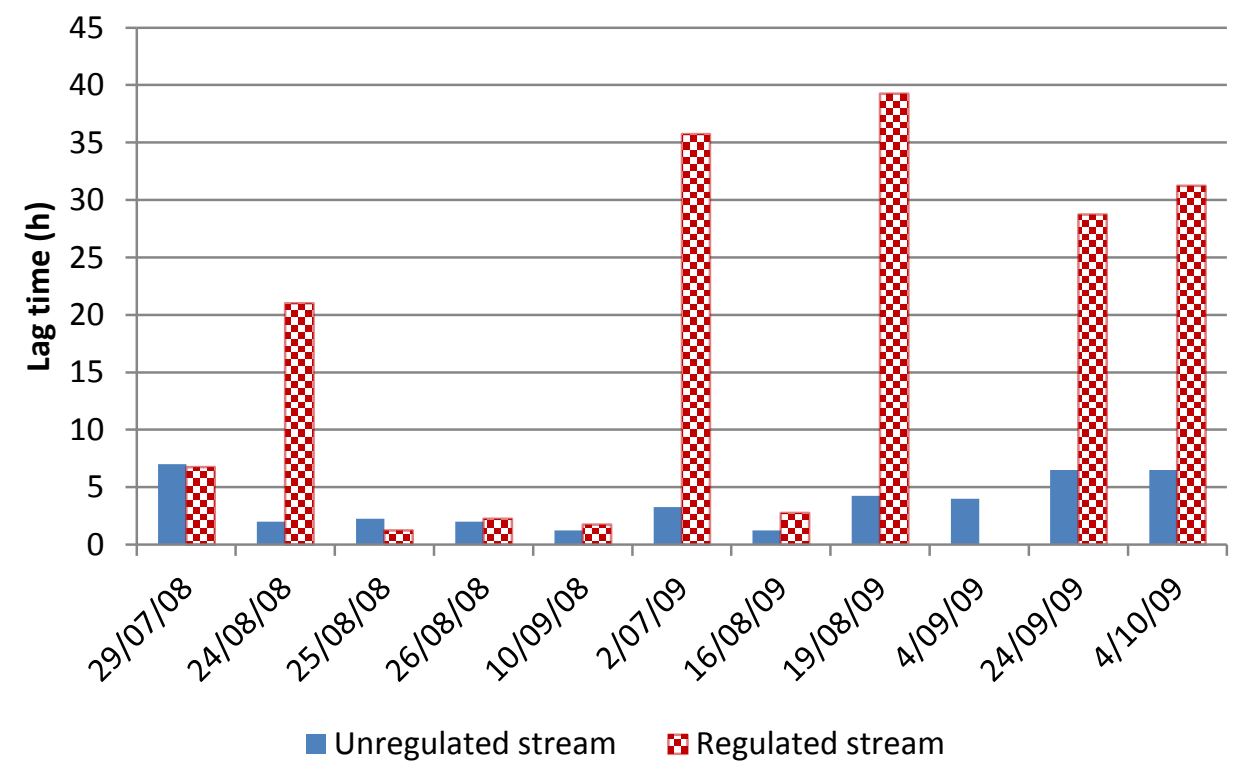

Figure 4.13: Lag time for unregulated and regulated streams in response to select storm events. 
ranged from $1.25 \mathrm{~h}$ to $7 \mathrm{~h}$, while lag time on the regulated stream ranged from $0 \mathrm{~h}$ to $39.25 \mathrm{~h}$, with an average lag time of $3.6 \mathrm{~h}$ and $16.4 \mathrm{~h}$ respectively. Measured peak streamflow levels and derived storm discharge volumes were higher and storm recessions were steeper on the unregulated stream as compared to the regulated stream.

In the three instances when lag time was shorter on the regulated stream, lag times differed between the two streams by $0.25,1$, and $4 \mathrm{~h}$. It is likely that the regulated stream responded more quickly on these occasions because antecedent wetness conditions were high and there was an overlap in stream response from a previous rainfall event. In all three cases, a storm had occurred between $6 \mathrm{~h}$ and $16 \mathrm{~h}$ prior to the commencement of the studied event.

Water level measurements showed that Pond B first overflowed on July 3, 2008. At this time, it is likely that Pond C was already full and overflowing based on the occurrence of flow at the regulated catchment outlet. Prior to Pond B's overflow, it filled slowly, with levels rising from $1.0 \mathrm{~m}$ to $2.0 \mathrm{~m}$ (pond full level) over the course of one month (Figure 4.14, red line). During this period of rise, a total of $54.8 \mathrm{~mm}$ of rain fell in the catchment. The following year, Pond B overflowed on July 13, but the period of filling occurred more quickly, with levels rising from $1.0 \mathrm{~m}$ to $2.0 \mathrm{~m}$ over a 7 -day period (Figure 4.14 , blue line). This quick rise was the result of a series of large rainfall events, beginning on June 28 when $100 \mathrm{~mm}$ of rain fell over a period of 65 hours. This was followed by a further $52 \mathrm{~mm}$ of rain falling between July 1 and July 13. This represents a rainfall volume of nearly three times that which fell during the pond filling period the previous year. Even though the period between October, 2008 and June, 2009 was $40 \%$ drier than normal, the catchment still showed a quick response to these storm events, with levels in Pond B beginning to rise within 4.5 hours of the initiation of the storm. 


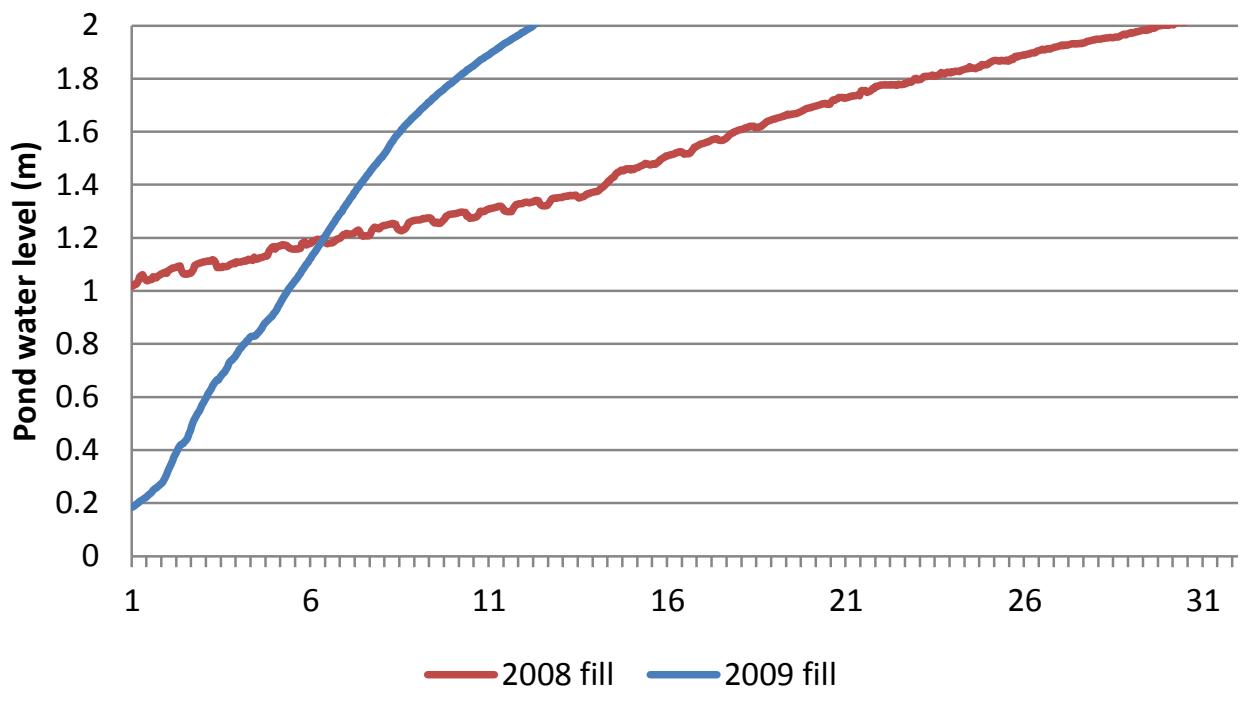

Figure 4.14: The filling of Pond B in 2008 (June 4-July 4) and 2009 (July 1-31). The pond overflows when water level at the recording site reaches $2.0 \mathrm{~m}$. Horizontal scale shows the number of days from the beginning of fill period.

\section{Flow volume}

Using the level-discharge relationships for the unregulated and regulated streams, total flow volumes were derived for both streams for the hydrologic year (Aug. 1, 2008 to Aug. 1, 2009). Figure 4.15 shows the derived total daily flow for the two catchments for this period, integrated for catchment area. Over this period, total flow volume in the unregulated catchment was $555 \mathrm{ML}$, which, when integrated for catchment area equals $360 \mathrm{ML} / \mathrm{km}^{2}$. For the same period, total flow volume on the regulated stream was $154 \mathrm{ML}$, or $216 \mathrm{ML} / \mathrm{km}^{2}$. Assuming catchment equivalence, this represents a decrease in volume of $144 \mathrm{ML} / \mathrm{km}^{2}$ for the regulated catchment. The differences in flow volume found between the two catchments will be discussed further in the catchment water balance section below.

Total flow volume per area on a monthly basis for the unregulated and regulated streams is summarised in Table 4.1. A calculation of the volume greater than the 


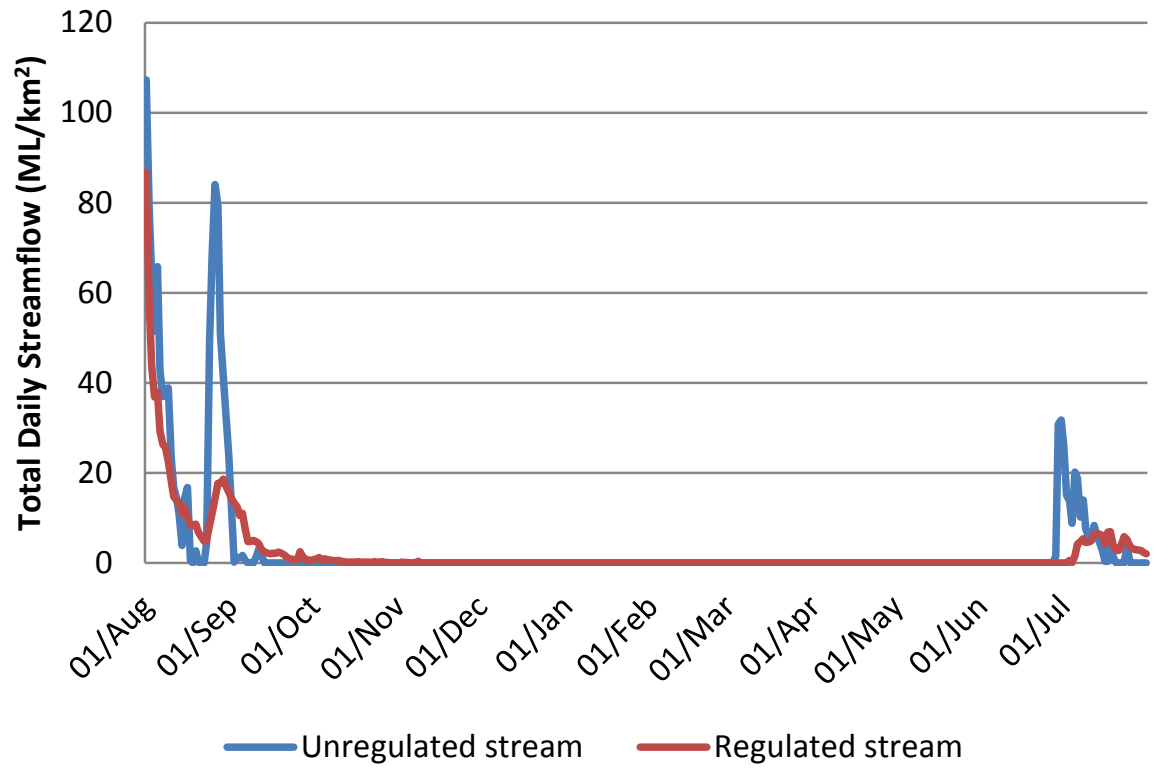

Figure 4.15: Total daily streamflow derived for the unregulated and regulated streams, Aug 1, 2008 to Aug 1, 2009. Streamflow volumes have been adjusted for catchment size.

Table 4.1: Total monthly volume of flow for the unregulated and regulated streams including percentage of flow reduction or gain on the regulated stream as compared to the unregulated stream.

\begin{tabular}{|l|l|l|l|}
\hline & $\begin{array}{l}\text { Unregulated } \\
\text { flow }\left(\mathbf{M L} / \mathbf{k m}^{2}\right)\end{array}$ & $\begin{array}{l}\text { Regulated } \\
\text { flow } \\
\left(\mathbf{M L} / \mathbf{k m}^{2}\right)\end{array}$ & $\begin{array}{l}\text { Difference in flow volume, } \\
\text { regulated to unregulated } \\
\text { stream }\end{array}$ \\
\hline August, 2008 & 258.4 & 154.5 & $-40 \%$ \\
\hline September, 2008 & 5.3 & 30.2 & $+82 \%$ \\
\hline October, 2008 & 0 & 2.5 & $+100 \%$ \\
\hline November, 2008 & 0 & 0 & no difference \\
\hline December, 2008 & 0 & 0 & no difference \\
\hline January, 2009 & 0 & 0 & no difference \\
\hline February, 2009 & 0 & 0 & no difference \\
\hline March, 2009 & 0 & 0 & no difference \\
\hline April, 2009 & 0 & 0 & no difference \\
\hline May, 2009 & 0 & 0 & no difference \\
\hline June, 2009 & 40.6 & 0 & $-100 \%$ \\
\hline July, 2009 & 55.7 & 28.8 & $-48 \%$ \\
\hline TOTAL & 360 & 216 & $-40 \%$ \\
\hline
\end{tabular}


accepted $200 \%$ of measured stream discharge was made. There were no values greater than the $200 \%$ level for the regulated stream, but a total of $65.6 \mathrm{ML}$ greater than the $200 \%$ level was found for the unregulated stream, which represents approximately $12 \%$ of the total volume of calculated flow. Values above this range were measured in August 2008 and June 2009 during large storm events. The third column of Table 4.1 shows the percentage change in flow on the regulated stream as compared to the unregulated stream. Flow was greater on the regulated stream in September and October; these times account for the continued flow on the regulated stream once flow on the unregulated stream had ceased.

\section{Catchment water balance}

On an annual basis, catchment water balance is calculated using:

$$
\Delta S=P-Q-E
$$

where $\Delta S=$ change in storage $(\mathrm{mm}), P=$ precipitation $(\mathrm{mm}), Q=\operatorname{runoff}(\mathrm{mm})$ and $E=$ evaporation $(\mathrm{mm})$. In the present analysis, the change in storage is assumed to be zero, as the water balance is based on a hydrologic year and catchment conditions were similar (i.e. ponds full) at the beginning and end of this period. Although evaporation was measured at the site using a Class A evaporation pan, these measurements were only collected between January and May, 2009, so could not be used to estimate total annual evaporation at the site. Instead, evaporation was calculated by rearranging the water balance equation:

$$
E=P-Q
$$

using precipitation collected at the Pond B climate station and discharge derived from level-discharge relationships at the catchment outlets. Calculated water balance results are summarised in Table 4.2.

The total PET (based on the Penman-Monteith method) from the Ongaonga climate station for the same period of time was $877.4 \mathrm{~mm}(2.4 \mathrm{~mm} / \mathrm{d})$, which is 
Table 4.2: Water balance for the unregulated and regulated catchments for the hydrologic year August 1, 2008 to August 1, 2009.

\begin{tabular}{|l|l|l|}
\hline & Unregulated catchment & Regulated catchment \\
\hline Precipitation & $656.5 \mathrm{~mm}$ & $656.5 \mathrm{~mm}$ \\
& $1.8 \mathrm{~mm} / \mathrm{d}$ & $1.8 \mathrm{~mm} / \mathrm{d}$ \\
\hline Discharge & $360 \mathrm{~mm}$ & $216 \mathrm{~mm}$ \\
& $0.98 \mathrm{~mm} / \mathrm{d}$ & $0.6 \mathrm{~mm} / \mathrm{d}$ \\
\hline Evaporation & $296.5 \mathrm{~mm}$ & $440.5 \mathrm{~mm}$ \\
& $0.8 \mathrm{~mm} / \mathrm{d}$ & $1.2 \mathrm{~mm} / \mathrm{d}$ \\
\hline
\end{tabular}

higher than the calculated PET (based on Thornthwaite's method) at the study catchment of $653 \mathrm{~mm}(1.8 \mathrm{~mm} / \mathrm{d})$. PET values show potential rates of evapotranspiration, so will always be higher than actual catchment rates unless water is freely available at all times of the year. Actual annual evaporation rates for the North Island of New Zealand have been estimated by Finkelstein (1973) as ranging between 650 and $850 \mathrm{~mm}$. Calculated catchment evaporation rates using the water balance equation are lower than this, suggesting that available water is a limiting factor, a likely scenario due to the extremely dry summer and autumn over the period of study. Uncertainty associated with the calculated discharge volumes for the study catchments may also be a factor in the low evaporation estimates.

Given that the main difference between the two catchments is the presence of the three ponds, an assessment of pond surface evaporation, seepage loss, and water takes was also made. A comparison between measured evaporation rates from the Class A evaporation pan and Pond B water levels was made for a period with no other pond inputs or outputs (i.e. no rainfall, no pond surface inflow, and no pond surface outflow). Two periods were chosen, representing summer (12 days, beginning late January, 2009) and autumn (36 days, March through April, 2009). The shorter summer period was a result of the evaporation pan being installed on Jan. 27 and the Pond B water level instrument showing an 
error in February. Measured evaporation rates were subtracted from total pond water lost during these two periods. This gives an average estimate of $0.35 \mathrm{~mm} / \mathrm{h}$ for pond seepage and water takes. The results of this analysis are presented in Table 4.3.

Table 4.3: Comparison of evaporation pan measurements and Pond B water levels during the summer and autumn period, 2009. The difference between the two values is attributed to a combination of pond seepage and water takes.

\begin{tabular}{|l|l|l|l|}
\hline & Summer average & Autumn average & Average for total period \\
\hline Pan evaporation & $\begin{array}{l}0.22 \mathrm{~mm} / \mathrm{h} \\
5.3 \mathrm{~mm} / \mathrm{d}\end{array}$ & $\begin{array}{l}0.18 \mathrm{~mm} / \mathrm{h} \\
4.3 \mathrm{~mm} / \mathrm{d}\end{array}$ & $\begin{array}{l}0.20 \mathrm{~mm} / \mathrm{h} \\
4.8 \mathrm{~mm} / \mathrm{d}\end{array}$ \\
\hline $\begin{array}{l}\text { Pond B total water } \\
\text { loss }\end{array}$ & $\begin{array}{l}0.80 \mathrm{~mm} / \mathrm{h} \\
19.2 \mathrm{~mm} / \mathrm{d}\end{array}$ & $\begin{array}{l}0.37 \mathrm{~mm} / \mathrm{h} \\
8.9 \mathrm{~mm} / \mathrm{d}\end{array}$ & $\begin{array}{l}0.55 \mathrm{~mm} / \mathrm{h} \\
13.2 \mathrm{~mm} / \mathrm{d}\end{array}$ \\
\hline $\begin{array}{l}\text { Difference } \\
\text { (attributed to } \\
\text { seepage and takes) }\end{array}$ & $0.58 \mathrm{~mm} / \mathrm{h}$ & $0.19 \mathrm{~mm} / \mathrm{h}$ & $0.35 \mathrm{~mm} / \mathrm{h}$ \\
$13.9 \mathrm{~mm} / \mathrm{d}$ & $4.6 \mathrm{~mm} / \mathrm{d}$ & $8.4 \mathrm{~mm} / \mathrm{d}$
\end{tabular}

From this analysis, open water evaporation rates for the summer and autumn period are, on average, $4.8 \mathrm{~mm} / \mathrm{d}$. Rates are higher for the summer $(5.3 \mathrm{~mm} / \mathrm{d})$ and lower for the autumn $(4.3 \mathrm{~mm} / \mathrm{d})$ which is explained by the decrease in daylength and average temperature over this period. Open pan evaporation is usually multiplied by a pan factor value to determine catchment evaporation rates. The suggested pan factor value for New Zealand is 0.69 (Finkelstein, 1973). When this is applied to the calculated averages and the rates are compared to the PET values from Ongaonga for the same periods, the evaporation rates are quite comparable: $3.64 \mathrm{~mm} / \mathrm{d}$ and $3.99 \mathrm{~mm} / \mathrm{d}$ for summer, and $2.98 \mathrm{~mm} / \mathrm{d}$ and $2.27 \mathrm{~mm} / \mathrm{d}$ for autumn for the study catchment and Ongaonga respectively. This suggests that the open pan evaporation rates measured at the study catchment are reasonable; therefore these will be used in the analysis of pond seepage.

Over the lifetime of a pond, annual seepage rates will decrease as fine sediment and organic matter are deposited within the pond. However, lateral seepage rates are likely to remain more stable through time. On a seasonal basis, seepage will 
decrease as pond levels drop in the dry season because less water is available for seepage. Additionally, seepage will decrease in the wet season as soil moisture levels adjacent to the pond increase thereby decreasing hydraulic head and flow out of the pond. An additional factor affecting seepage in the study catchment was noted as a result of the dry conditions throughout the summer and autumn. During this time, Pond A dried out completely and Ponds B and C had areas of their reservoirs that were dry. Drying led to cracks developing in the dry pond base (Figure 4.16), which would have caused an increase in seepage at the beginning of pond filling in July, 2009. Therefore, it is reasonable to expect seepage at each pond to vary both on a seasonal basis and over the lifetime of the pond.

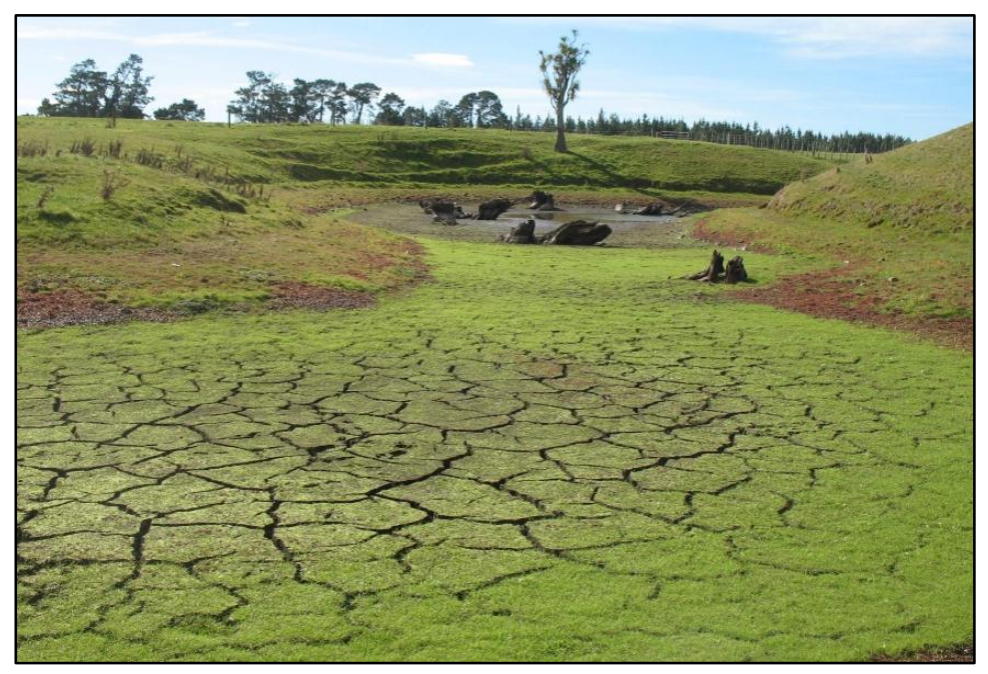

Figure 4.16: Cracking was observed in the dry sections of all three ponds during the summer and autumn study period. Photo shows cracking in Pond C, looking downstream towards the remaining stored water.

An estimate of seepage from Pond B was made using the difference between pond water losses (based on measured pond water levels) and pond evaporation (based on measured pan evaporation rates) over the summer and autumn time periods as given above. The differences, shown in Table 4.3 , are $0.58 \mathrm{~mm} / \mathrm{h}$ for the summer period and $0.19 \mathrm{~mm} / \mathrm{h}$ for the autumn period. Using an average seepage rate of $0.35 \mathrm{~mm} / \mathrm{h}$ for this period and integrating it for the maximum area of Pond B, a total seepage loss of 6.5 ML was estimated for the months of January 
through April. Although this rate was unlikely to be met over these four months because of dropping water levels and decreasing pond surface area, it is worth noting that the estimated seepage loss is almost equal to the total storage capacity of Pond B (7 ML).

An analysis of potential water takes from the ponds was completed. Over the course of the study, the regulated catchment was stocked more intensively (sheep and beef) from January, 2009. Although the catchment was not densely stocked and much of the area was used for cropping, it is likely that some water was taken from the ponds for stock use. Typical demand values are $1.6 \mathrm{~m}^{3} / \mathrm{y}$ for sheep and $20 \mathrm{~m}^{3} / \mathrm{y}$ for beef (Stewart and Rout, 2007). Based on observed numbers of stock in the regulated catchment, it is estimated that a total of $1 \mathrm{ML}$ would be taken from the ponds for stock use over the course of a year.

On an annual basis, a calculation of total annual water loss from the three ponds in the study catchment was made. This calculation was based on a number of limiting assumptions and is intended only to determine the magnitude of potential water loss from the ponds. Annual pond evaporation was derived using PET values from the Ongaonga climate station (for the study period), which were first adjusted back to open water evaporation using the 0.69 pan factor value (as discussed above). This gives a total annual pond evaporation loss of $15 \mathrm{ML}$. Although McGuinness (1984) suggests that seepage and evaporation loss from small ponds in the Ruataniwha Plains is approximately $50 \%$ of total storage, these results suggest that pond evaporation itself might actually be upwards of $100 \%$ of total pond storage. Pond seepage was calculated from the water balance (as described above) over the summer and autumn period and was found to be roughly equivalent to the total storage volume of Pond B. If this rough seasonal estimate is used as a conservative annual estimate, pond seepage for the catchment may be equivalent to total catchment pond storage (11.6 ML). Water takes from the ponds were estimated at $1 \mathrm{ML}$, as discussed above. This gives an estimated total of 27.6 ML of water lost for the three ponds in the regulated 
catchment. Adding in the total storage volume of the three ponds of 11.6 ML, this represents a total of $39.2 \mathrm{ML}$.

The estimated difference in annual streamflow volume between the unregulated and regulated catchments is $144 \mathrm{ML} / \mathrm{km}^{2}$ and the total estimated pond storage and losses in the regulated catchment are $55 \mathrm{ML} / \mathrm{km}^{2}$. This leaves a volume of $88 \mathrm{ML} / \mathrm{km}^{2}$ that is unaccounted for. A portion of this difference can be attributed to uncertainty in the derivation of the level-discharge relationship (which is used to calculate all flow volumes) and the uncertainty in the estimation of seepage, evaporation, water takes, and pond storage volumes in the regulated catchment. There may also be other processes in the catchments which are not fully understood and accounted for. For example, the lack of a distinct stream channel in the regulated catchment may lead to a greater volume of water which infiltrates the soil but does not contribute to baseflow on the regulated stream. Or, there may be groundwater flow which crosses catchment boundaries, leading, for example, to a greater loss than expected in the regulated channel. However, the broad differences between the two catchments in terms of flow volume and timing can be considered reliable, because they are also supported by sedimentologic and morphologic evidence (as discussed below). A further investigation into surface water and groundwater interactions in the two catchments would help clarify this discrepancy.

\subsubsection{Water quality}

The comparison of water quality parameters between the unregulated and regulated streams, and from upstream to downstream on the regulated stream, gives an indication of the effects of regulation, assuming other water quality influences are equivalent for both catchments. This assumption may be valid as the catchments have similar geology, climate, and soil characteristics. Both catchments also have similar agricultural practices with low stocking rates and some cropping, so fertiliser inputs are likely to be of the same magnitude. It is 
expected that water quality of the regulated stream and in particular, of the ponds, will be more degraded than water quality of the unregulated stream. With regard to previous studies undertaken on small dams, a decrease in dissolved oxygen levels and an increase in water temperature on the regulated stream are expected (e.g. Maxted et al., 2005). The main drawback to the present analysis is the low number of samples taken on the unregulated stream due to long periods of no flow. Therefore, results presented should be considered as preliminary and no tests of statistical significance have been completed as they are considered inappropriate given the data population size.

\section{pH}

The measurement of $\mathrm{pH}$ gives an indication of the degree of acidity or alkalinity of water, with lower $\mathrm{pH}$ values representing a higher $\mathrm{H}+$ concentration. It provides a general characteristic of water quality and can influence and be influenced by biological processes (MFE, 1997) as well as by fertiliser application, and organic matter and microorganisms in the soil. Typically, groundwater is more basic $(\mathrm{pH}>7)$, while surface water may be acidic $(\mathrm{pH}<7)$ or basic depending on whether it is dominated by precipitation, groundwater, or evaporation. The average $\mathrm{pH}$ on the Tukipo River at SH50 is 8.0 and ranges between 6.32 and 8.86 ( $\mathrm{n}=17 ; 1999-2009)$. Higher $\mathrm{pH}$ values may occur naturally in the late summer period under low flow conditions and increased macrophytes and periphyton levels (HBRC, 1998). It is expected that $\mathrm{pH}$ levels in the study catchments are similar to Tukipo River values, without the high values which occur in late summer, as no streamflow was observed in either study catchment at this time. A slight difference in $\mathrm{pH}$ values between the two catchments may exist as a result of regulation.

Over the period of study, it was found that average $\mathrm{pH}$ values at the outlet of the unregulated and regulated stream catchments were similar (7.5 and 8.0 respectively), although the unregulated catchment had consistently lower $\mathrm{pH}$ 
levels. Values ranged from 6.8-8.0 at the unregulated stream outlet and 7.6-8.5 at the regulated stream outlet and were similar to the range of values measured on the Tukipo River at SH50. On the regulated stream, average $\mathrm{pH}$ increased from 6.4 at the top of the catchment to 8.0 at the outlet. Pond B had slightly higher $\mathrm{pH}$ values and a higher range of values (between 6.44 and 9.52) as compared to the rest of the regulated stream.

\section{Dissolved oxygen (DO)}

Dissolved oxygen is a measure of the concentration of oxygen in water and is given in units of $\mathrm{mg} / \mathrm{L}\left(\mathrm{mg} \mathrm{O}_{2}\right.$ per litre $\left.\mathrm{H}_{2} \mathrm{O}\right)$ or as a percent saturation level (\% of maximum). An unpolluted mountain stream has DO levels near 100\%, while spring water, being underground for long periods, often has quite low DO levels (Lampert and Sommer, 2007). Dissolved oxygen concentrations will increase with turbulent streamflow as more oxygen becomes incorporated into the water. The Tukipo River has a DO range of 7 to $15 \mathrm{mg} / \mathrm{L}$, with an average value of $10 \mathrm{mg} / \mathrm{L}$ ( $\mathrm{n}=109 ; 1994-2009)$. It is expected that DO levels are slightly higher in the unregulated catchment as compared to the regulated catchment, and that DO levels in the regulated catchment are higher in the stream as compared to the ponds.

However, it was found that dissolved oxygen levels at the outlet of the unregulated stream were lower on average as compared to the regulated stream (12.9 $\mathrm{mg} / \mathrm{L}$ and $17.7 \mathrm{mg} / \mathrm{L}$ respectively). In both catchments, the lowest DO values were found in Pond B and Pond C (2.8 and $3.9 \mathrm{mg} / \mathrm{L}$ respectively), with levels increasing between Pond C and the regulated stream outlet as expected. This increase was aided by the aeration of stream water as it flowed over a $4 \mathrm{~m}$ drop (knickpoint) located $170 \mathrm{~m}$ upstream from the regulated stream outlet. This fall of water is also the likely explanation for the higher average DO values at the regulated stream outlet as compared to the unregulated stream outlet. If a comparison is made between DO levels at the unregulated stream outlet and 
those upstream of the knickpoint on the regulated stream, average DO levels are higher on the unregulated stream $(12.9 \mathrm{mg} / \mathrm{L}$ and $9.0 \mathrm{mg} / \mathrm{L}$ respectively), as would be expected.

Therefore, DO levels are slightly degraded with the storage of water in the ponds, but levels increase again as flow continues downstream. In general, it would be expected that stream regulation would lead to slightly lower DO levels as compared to an unregulated stream; however, local catchment conditions, including the length of uninterrupted streamflow and instream channel roughness, will have an influence on these levels.

\section{Total dissolved solids (TDS)}

The total dissolved solids measure is the weight of organic and inorganic matter dissolved in water. It is generally used as an indicator of drinking water quality, although high TDS levels can also affect aquatic organisms. In the present study, TDS measures are derived from EC measures, meaning that trends for both TDS and EC will be the same. It is expected that TDS levels are higher on the regulated stream as compared to the unregulated stream and that overall levels are highest in the ponds, particularly during the summer period when the concentration of dissolved matter increases as water evaporates.

Average values of TDS taken at stream catchment outlets show that the regulated stream has higher average TDS values $(89.8 \mathrm{mg} / \mathrm{L})$ as compared to the unregulated stream $(84.4 \mathrm{mg} / \mathrm{L})$. However, when making direct comparisons of the three paired measures, two of these pairs show the regulated stream having lower TDS levels than the unregulated stream. Values range from 62 to $101 \mathrm{mg} / \mathrm{L}$ on the unregulated stream and 80 to $104 \mathrm{mg} / \mathrm{L}$ on the regulated stream.

Variations along the regulated stream also exist, with the highest TDS values found in Ponds B and C during the summer period. Values range from 69 to $110 \mathrm{mg} / \mathrm{L}$ in Pond B and 85 to $118 \mathrm{mg} / \mathrm{L}$ in Pond C. In 8 cases out of 9, Pond C had higher TDS levels as compared to Pond B. However, the downstream change 
from Pond A to the outlet of the regulated stream revealed that overall TDS values decreased in the downstream direction in 4 cases out of 5 .

\section{Electrical conductivity (EC)}

Electrical conductivity measures the ability of water to conduct an electric current. It is a function of water temperature and the total number of dissolved ions in water. Distilled water has a range of electrical conductivity between 0.5 and $3 \mu \mathrm{S} / \mathrm{cm}$; as water purity decreases, these measures increase. Water that is slowly transmitted to the stream (i.e. underground) has more opportunity to pick up dissolved ions. Therefore, in streams with a large groundwater component, or during baseflow conditions, electrical conductivity levels will be comparatively high. In contrast, a corresponding decline in electrical conductivity will occur at high discharges when quickflow and precipitation contributions are higher (Boyd, 2000).

All EC values are automatically corrected for temperature at the time of measurement. Tukipo River levels of EC range from 92 to $207 \mu \mathrm{S} / \mathrm{cm}$ with an average of $143 \mu \mathrm{S} / \mathrm{cm}(\mathrm{n}=77 ; 1999-2009)$. It is expected that values in the study catchment are within this range, with the highest values measured within the ponds. It is likely that levels are similar between the unregulated and regulated streams, with perhaps a slight increase on the regulated stream as a result of the longer residence time of water in the ponds.

The trends found for EC are the same as those found for TDS because, as mentioned above, TDS measured in the field is approximated using EC values. Average values of EC were $169.5 \mu \mathrm{S} / \mathrm{cm}$ at the unregulated stream outlet and $180.7 \mu \mathrm{S} / \mathrm{cm}$ at the regulated stream outlet, falling within the range of values found on the Tukipo River. Electrical conductivity also generally decreased in the downstream direction on the regulated stream, with higher values found in Pond $\mathrm{B}$ and Pond $\mathrm{C}$ in all cases. 


\section{Water temperature}

The maximum stream temperature and the annual range of temperature expected in a stream are important indicators of ecosystem health. The Tukipo River has a measured water temperature range between 6 and $21^{\circ} \mathrm{C}$, with maximum temperatures reached in the summer months. It is expected that stream temperatures in the study catchments are similar to the Tukipo River, although higher temperatures may be found because the study streams have lower discharges. This effect is likely to lead to slightly higher stream temperatures on the regulated stream as compared to the unregulated stream.

At the catchment outlet, the unregulated stream had a lower average temperature $\left(9.2^{\circ} \mathrm{C}\right)$ as well as a lower temperature range $\left(7.4\right.$ to $\left.11.5^{\circ} \mathrm{C}\right)$ as compared to the regulated stream. Average temperature at the outlet of the regulated stream was $11.1^{\circ} \mathrm{C}$ with a range of 7.4 to $15.7^{\circ} \mathrm{C}$. The regulated stream showed a general increase in temperature from upstream to downstream. On the two occasions when measurements were made for comparison, water temperatures in Pond B and Pond $\mathrm{C}$ were slightly higher than pond outlet temperatures. As both streams were not flowing throughout the summer months when stream temperatures would be the highest, it is unknown what the maximum summer stream temperatures might be. Based on available measured water temperatures, the effect of regulation has been a slight increase in stream temperature at the regulated stream outlet as compared to the unregulated stream outlet.

\section{Water quality guidelines}

Water quality measures at the field site were compared to recommended levels for stream health based on Hawke's Bay Regional Council guidelines and those recommended by Ausseil (2008) for the Tukituki River. It should be noted that there will be issues in comparing recommended water quality levels derived for rivers to water quality measured in small streams. Because of the concentration effect (where pollutant concentrations increase with decreasing flow volumes), it 
is likely that the study catchments will have higher pollutant concentrations in their small streams and fall below recommended levels more often. However, water quality levels are often set to maintain healthy instream habitat, so recommended levels may not be as pertinent for the intermittent agricultural streams of the study catchments which do not have high habitat diversity. Measured and recommended water quality levels are summarised in Table 4.4. Water quality measures from the Tukipo River SH50 gauging site are included in the table for comparison purposes but are not discussed further.

Table 4.4: Summary of measured water quality values for the study catchments and recommended water quality values from Ausseil (2008).

\begin{tabular}{|l|l|l|l|l|}
\hline Parameter & $\begin{array}{l}\text { Unregulated } \\
\text { stream outlet }\end{array}$ & $\begin{array}{l}\text { Regulated } \\
\text { stream outlet }\end{array}$ & $\begin{array}{l}\text { Tukipo River at } \\
\text { SH50 }\end{array}$ & $\begin{array}{l}\text { Recommended } \\
\text { maximum levels }\end{array}$ \\
\hline $\begin{array}{l}\text { Water } \\
\text { temp }\left({ }^{\circ} \mathrm{C}\right)\end{array}$ & $\begin{array}{l}\text { Range 7.4-11.5 } \\
\text { Mean 8.9 }\end{array}$ & $\begin{array}{l}\text { Range 7.4-15.7 } \\
\text { Mean 11.8 } \\
\text { Ponds 3.7-20.8 }\end{array}$ & $\begin{array}{l}\text { Range 6.0-21.0 } \\
\text { Mean 13.0 }\end{array}$ & $\begin{array}{l}\text { No higher than } \\
19.0\end{array}$ \\
\hline $\mathrm{pH}$ & $\begin{array}{l}\text { Range 6.8-8.0 } \\
\text { Mean 7.5 }\end{array}$ & $\begin{array}{l}\text { Range 7.6-8.6 } \\
\text { Mean 8.0 } \\
\text { Ponds 6.3-9.5 }\end{array}$ & $\begin{array}{l}\text { Range 7.3-8.7 } \\
\text { Mean 7.8 }\end{array}$ & $\begin{array}{l}\text { Tolerance 5.9-9.5 } \\
\text { Optimum 6.7-7.8 }\end{array}$ \\
\hline $\begin{array}{l}\text { DO } \\
(\mathrm{mg} / \mathrm{L})\end{array}$ & $\begin{array}{l}\text { Range 10.2-16 } \\
\text { Mean 12.9 }\end{array}$ & $\begin{array}{l}\text { Range 11.1-17.7 } \\
\text { Mean 13.8 } \\
\text { Ponds 2.7-18.0 }\end{array}$ & $\begin{array}{l}\text { Range 7.0-15.0 } \\
\text { Mean 10.0 }\end{array}$ & No less than 8.0 \\
\hline
\end{tabular}

Based on the recommended levels, water quality levels were exceeded in both the ponds and the regulated stream on a number of occasions. Recommended levels for water temperature (no higher than $19.0^{\circ} \mathrm{C}$ ) and $\mathrm{pH}$ (within the tolerance range of 5.9 to 9.5 ) were exceeded within the ponds 3 times out of 23 total measures but were never exceeded at the outlet of either stream. Recommended levels of DO (no less than 8.0) were exceeded 8 times out of 23 within the ponds and 3 times out of 21 at the regulated stream outlet. Water quality guidelines for water temperature, $\mathrm{pH}$, and $\mathrm{DO}$ were not exceeded on the four occasions that measurements were taken on the unregulated stream. This suggests that water quality is more degraded within the ponds and on the regulated stream as compared to the unregulated stream. However, because of the low number of 
samples taken on the unregulated stream, this result should only be taken as preliminary.

\subsubsection{Sediment and morphology}

\section{Catchment sediment sources}

Sources of sediment in both catchments are associated primarily with the channel and near-channel zones. Sediment is eroded from the channel bed and banks at high flow levels. When either stream has incised by approximately $1 \mathrm{~m}$, a layer of fine gravel is reached, which adds coarse material to the channel through bed and bank erosion.

Sediment is also added to the stream channel through bank erosion by stock grazing on the channel banks. This was directly observed at both Pond B and Pond C, where stock trampling initiated sediment erosion at the pond edge. Coarse material eroded in this manner and deposited into the pond is not transported any further downstream.

Gravels are exposed in the terrace scarps, found in both catchments downstream of the knickpoint location (Figure 4.17; the dynamics of the knickpoints are discussed further below). As the location of the knickpoint on the regulated catchment is further downstream (as compared to the unregulated catchment), the terraces do not constitute a significant source of sediment to the regulated stream channel. However, the terraces do contribute coarse sediment to the unregulated channel in its lower reaches.

\section{Suspended solids}

Analysis of suspended solids from the study catchment streams reveals that concentrations are low at both the unregulated and regulated stream outlets and are much lower in average value and range as compared to suspended solids values from the Tukipo River. The Tukipo River at the SH50 gauging site has a 


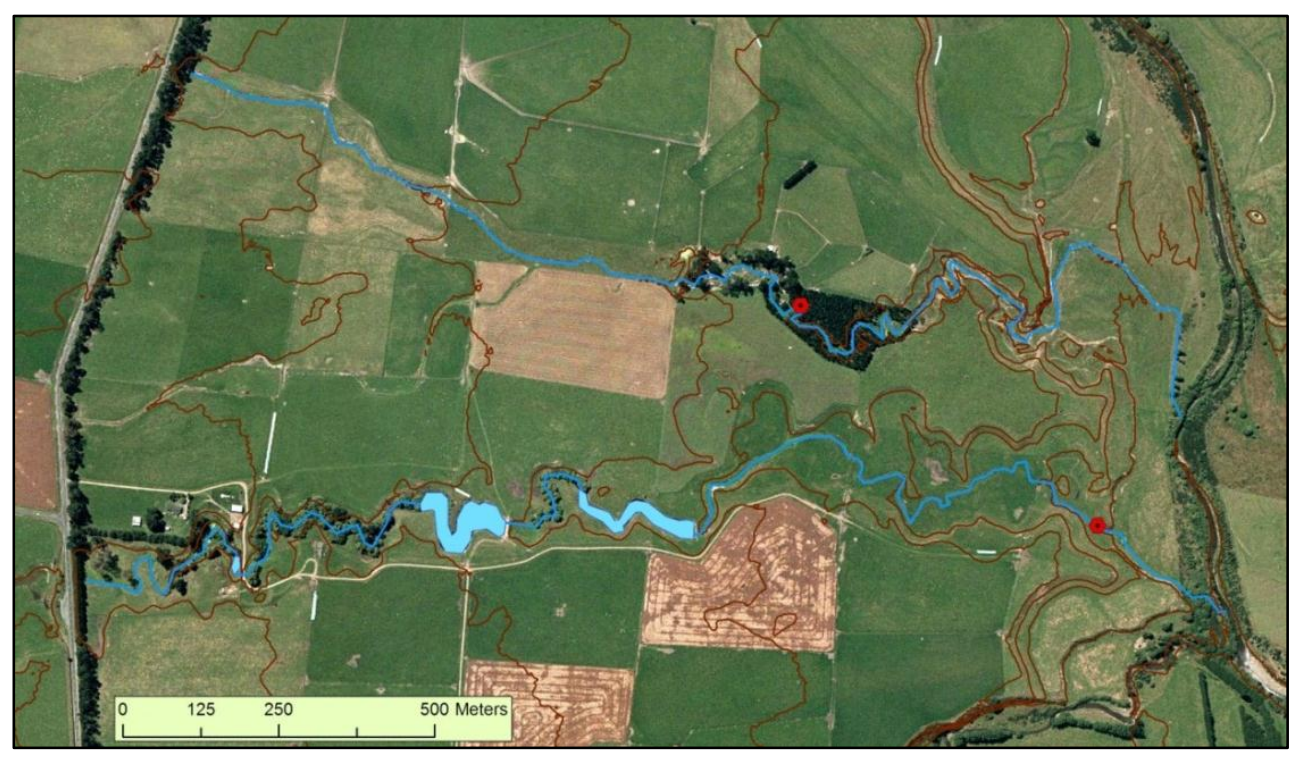

Figure 4.17: Location of knickpoints (red circles) in the unregulated and regulated catchments. Contour lines are plotted at $5 \mathrm{~m}$ intervals.

range of $<1$ to $440 \mathrm{mg} / \mathrm{L}$ (measured over a range of flow levels at quarterly to monthly intervals since 1994). The unregulated stream has a range of 0 to $29.3 \mathrm{mg} / \mathrm{L}$ (4 samples), and the regulated stream has a range of 2.8 to $18.2 \mathrm{mg} / \mathrm{L}$ (6 samples). Although average suspended solids concentration was higher at the unregulated stream outlet as compared to the regulated outlet, it was not consistently higher at all sampling times. A t-test was applied to concentrations at both stream outlets to test if there was a significant difference between the two locations. It was found that no significant difference exists $(t(3)=0.82$, 2-tailed, $\mathrm{p}=0.05)$.

In an analysis of suspended solids concentrations collected along the length of the regulated stream, concentrations were shown to decrease 3 out of 4 times between Pond A and the regulated stream outlet. In 3 out of 4 cases, suspended solids concentrations decreased between Pond A and Pond B, and in all four cases levels rose between Pond C and the catchment outlet. These trends would be expected because sediment trapping within the ponds would lower concentrations downstream, but concentrations would increase again after the water had passed through all three ponds. A t-test was applied to suspended sediment concentrations measured at Pond A and at the regulated stream outlet 
to see if a significant difference exists between these two locations. Again, it was found that no significant difference exists $(t(5)=0.02$, 2-tailed, $\mathrm{p}=0.05)$.

Further investigation of suspended solids concentrations, with samples collected across a higher range of flow, is needed to determine whether or not a difference exists between the two systems. However, this will not be completed in the present study.

\section{Channel bed sediment}

Major differences were found in the nature of channel bed sediment between the unregulated and regulated streams (Figure 4.18). The unregulated channel bed sediments range from medium to fine gravel $\left(\mathrm{d}_{50}=-3.53 \varphi\right.$; pebble), with median values showing a slight fining in the downstream direction (Figure 4.19). The regulated channel bed sediments range from fine sand to very coarse silt $\left(\mathrm{d}_{50}=\right.$ 2.76 $\varphi$; fine sand), with median values showing a slight fining in the downstream direction and the lowest median values found on the dry beds of Ponds A and C. The difference in channel bed sediment size is apparent in photographs of the unregulated and regulated stream beds taken during the summer no flow period (January, 2009) (Figure 4.20).

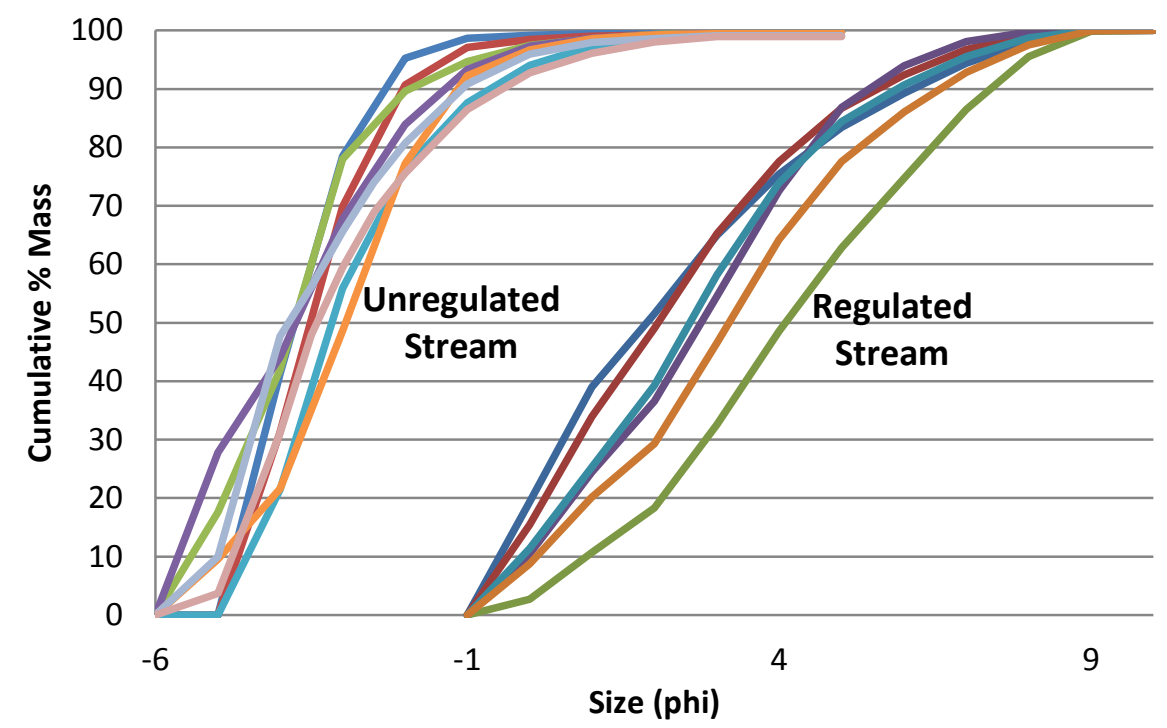

Figure 4.18: Channel bed sediment size distribution for various locations on the unregulated and regulated streams. Each line represents a discrete sediment sample. 


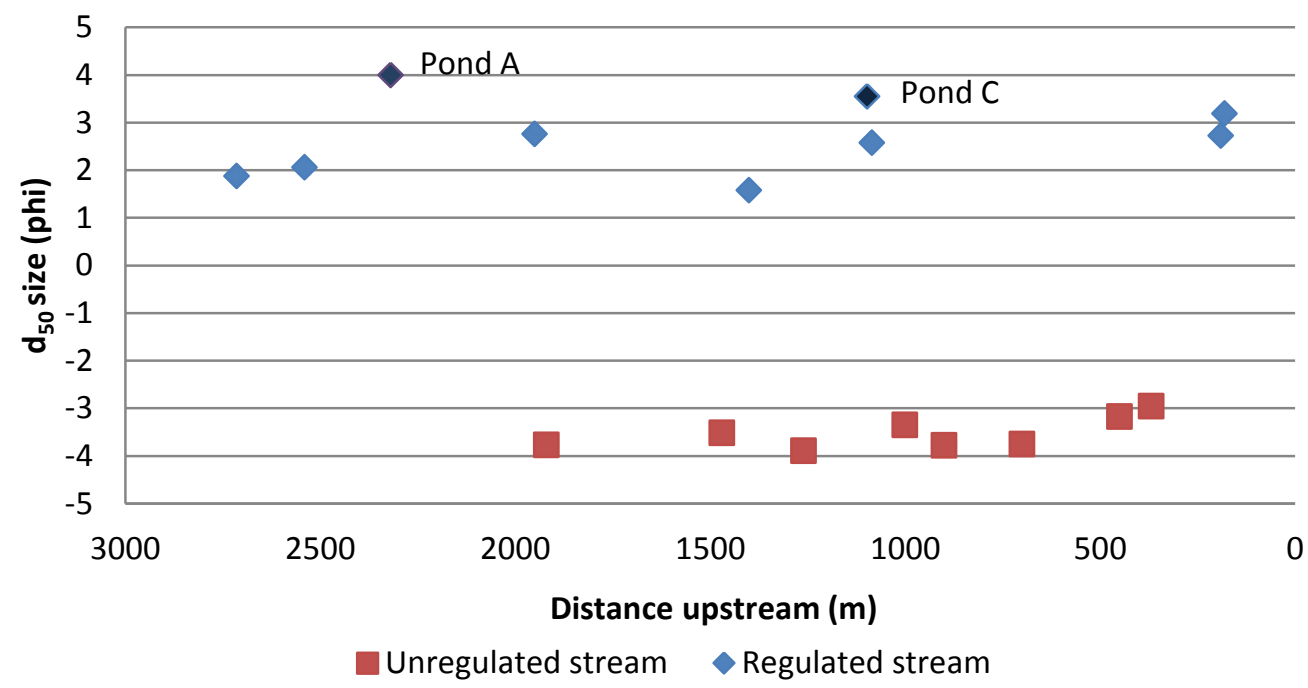

Figure 4.19: Median ( $\mathrm{d}_{50}$ ) value of each channel bed sediment sample with distance upstream from the catchment outlet for the unregulated and regulated streams.

Ten sediment pits were dug to depths of 0.2 to $0.93 \mathrm{~m}$ (the depth at which fine gravels were reached) at various locations on the regulated stream (locations shown in Figure 4.10). It was found that the depth to the gravel layer decreases in a downstream direction (i.e. the gravel is closer to the surface further downstream as compared to upstream locations). The sediment profile of each pit was used to characterise temporal changes in stream depositional environment. At all locations, there has been a slight coarsening upwards, with mean sediment size moving from coarse silt and very fine sand up to fine sand and medium sand.
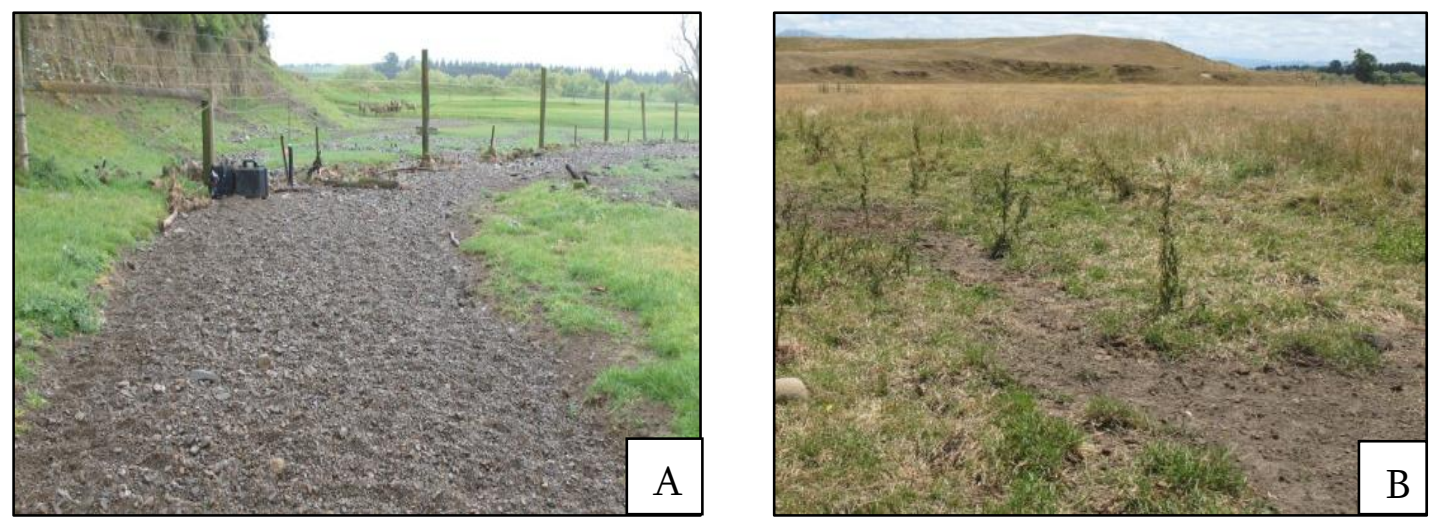

Figure 4.20: Channel bed of the unregulated (A) and regulated (B) streams during the summer no flow period (January, 2009). Channel width is $2 \mathrm{~m}$ on the unregulated stream and $0.5 \mathrm{~m}$ on the regulated stream (between vegetated banks). Photos are from the outlet of each catchment. 
The pits immediately downstream of Pond B and Pond C show the smallest change, suggesting a more stable environment of deposition through time. The two pits showing the greatest change over time are located near the top of the catchment, upstream of Pond A and between Ponds A and B.

There are various possible reasons for the coarsening upwards of channel bed sediment. A coarsening of deposited sediment may be related to either a change over time in the energy of flow (enabling coarser material to be transported and subsequently deposited) or to a change over time in the size of sediment available for transport. In the first instance, a change in energy of flow may result from an increase in precipitation volume and/or an increase in precipitation intensity over time. A study by Griffiths (2007) revealed a slight decrease in annual precipitation and a decrease in daily rainfall extremes for the Hawke's Bay region between 1950 and 2004. No significant change in annual rainfall volumes was found between 1957 and 2007 using regional precipitation data from Parkhill and Makaretu North gauges (representative of the Upper Tukipo catchment).

An alternative explanation for the coarsening of channel bed sediment is that a new source of sediment has become available for transport because of a change in land use and/or a decrease in vegetation cover. Although it is likely that a number of factors have combined to create this change, a focus on the post-dam period using aerial photographs from 1953 to the present indicates a concurrent increase in land use (including the construction of tracks and the dams themselves) in the study catchment and a decrease in tree cover along the channel banks. This change suggests that coarser sediment may have become available for transport over this period.

Assuming that the fine gravel layer represents the flow regime that existed prior to dam construction, a rough calculation of deposition rates can be made. This calculation is also based on the assumption that no erosion has occurred over this period. Both assumptions are deemed valid, given that there are no abrupt changes in sediment size or composition in the sediment column. Dam 
construction was estimated as 1953 for Pond A and 1970 for Ponds B and C. Average depositional rates of 1.5 to $2 \mathrm{~cm} / \mathrm{y}$ were found. These rates seem reasonable for the area, but it should be noted that further study would be necessary to determine the precise timing of the start of deposition, as the fine gravel layer may not be associated with the flow regime immediately prior to dam construction.

\section{Channel bed scour}

Following the construction of large dams, changes to the flow regime and subsequent transport of sediment can cause scour and channel armouring directly downstream of the dam (e.g. Williams and Wolman, 1984). Although it has been suggested that this will also occur downstream of small dams, in the present study no evidence of scour or armouring was found along the length of the regulated channel. In fact, it was observed that channel incision remained weak throughout the entire length of the regulated stream. The lack of scour and armouring may be the result of the lower energy flows exiting the ponds which are unable to erode available channel sediment.

In order to test this idea, it first must be ascertained whether measured streamflow is theoretically able to move channel bed sediment. If it can, there must be other reasons why bed sediment is not being moved, and why the channel bed is not being incised as expected. Threshold values for sediment entrainment can be measured using hydrodynamic factors such as velocity, shear stress, and/or stream power. In the present study, the critical stream velocity required to move a sediment particle was calculated using measured stream velocities and bed sediment characteristics. The critical stream velocity equation used in the present study is given below. The equation was initially derived from flume experiments and refers to velocity near the channel bed, which will be lower than stream velocities from current meter measurements in the catchment. However, because the streams are fairly shallow $(16-18 \mathrm{~cm}$ at bankfull levels) and 
velocity measurements were not taken during times of high flow (when the majority of sediment transport would be expected to occur), the calculation will be used to give a general magnitude of velocity expected. This calculation will be made for both the unregulated and regulated streams for comparison purposes.

The critical velocity required to move a particle is given by:

$$
V c=0.155 \sqrt{d}
$$

where $V c=$ critical velocity $(\mathrm{m} / \mathrm{s})$ and $d=$ average particle diameter $(\mathrm{mm})(\mathrm{USBR}$, 1977). Using measured channel bed $d_{50}$ values, the unregulated stream has a critical velocity of $0.53 \mathrm{~m} / \mathrm{s}$ and the regulated stream has a critical velocity of $0.06 \mathrm{~m} / \mathrm{s}$. Measured velocities taken at the catchment outlets at times of field discharge measurements range from 0.14 to $1.09 \mathrm{~m} / \mathrm{s}$ for the unregulated stream and 0.2 to $1.0 \mathrm{~m} / \mathrm{s}$ for the regulated stream, showing that median bed sediment in both channels should theoretically be moved at these velocities. The regulated stream channel should actually be capable of moving pebble sized sediment, as calculated by rearranging the critical velocity equation and using maximum measured stream velocities to solve for $d$.

This leaves the question why, if regulated stream velocities are capable of transporting much larger sediment, the stream has not cut down into its channel and the channel itself remains composed of fine material. The answer likely lies in a combination of channel characteristics and land use factors. Directly downstream of the ponds, the regulated channel is 5 to $10 \mathrm{~cm}$ deep with undefined banks covered in grass (Figure 4.21). The undefined banks are created and maintained in part by cattle trampling the stream edge, which causes bank material to collapse and ponding of water to occur (Figure 4.22). During times of high flow (i.e. throughout the winter months), flow is not confined within the channel banks, and water spreads laterally across the adjacent non-channelised area. Without flow confined to the channel, available stream energy and erosion potential is decreased. 

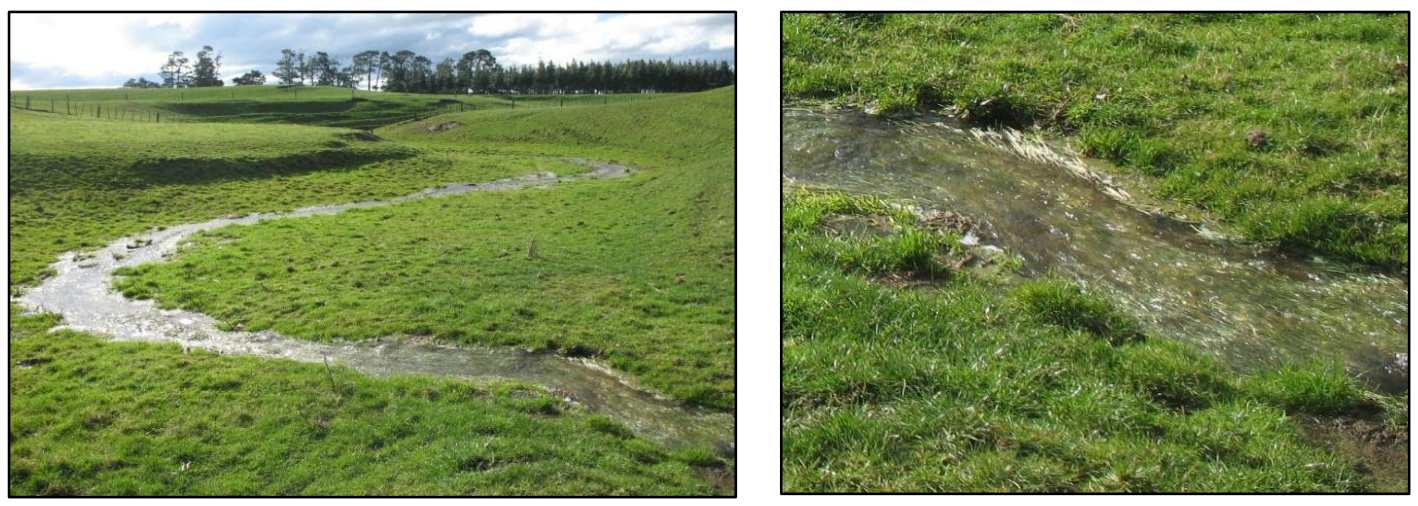

Figure 4.21: Flow on the regulated stream looking downstream from the outlet of Pond C. The photo on the right is an enlargement of the photo on the left. Channel banks are not well defined, and banks and bed are almost completely vegetated with grass. Stream width in the photo is $0.55 \mathrm{~m}$.

A second influence is the grass covering the channel bed and banks which will reduce the stream's erosive capability. This effect has been noted elsewhere, for example by Blackham et al. (2009) who found that grassy vegetation greatly increased the erosion resistance of streams in Australia. Petts (1979) also suggests that a lack of scour downstream of reservoirs may occur when channels are cohesive or well vegetated, thereby reducing the opportunity for erosion.
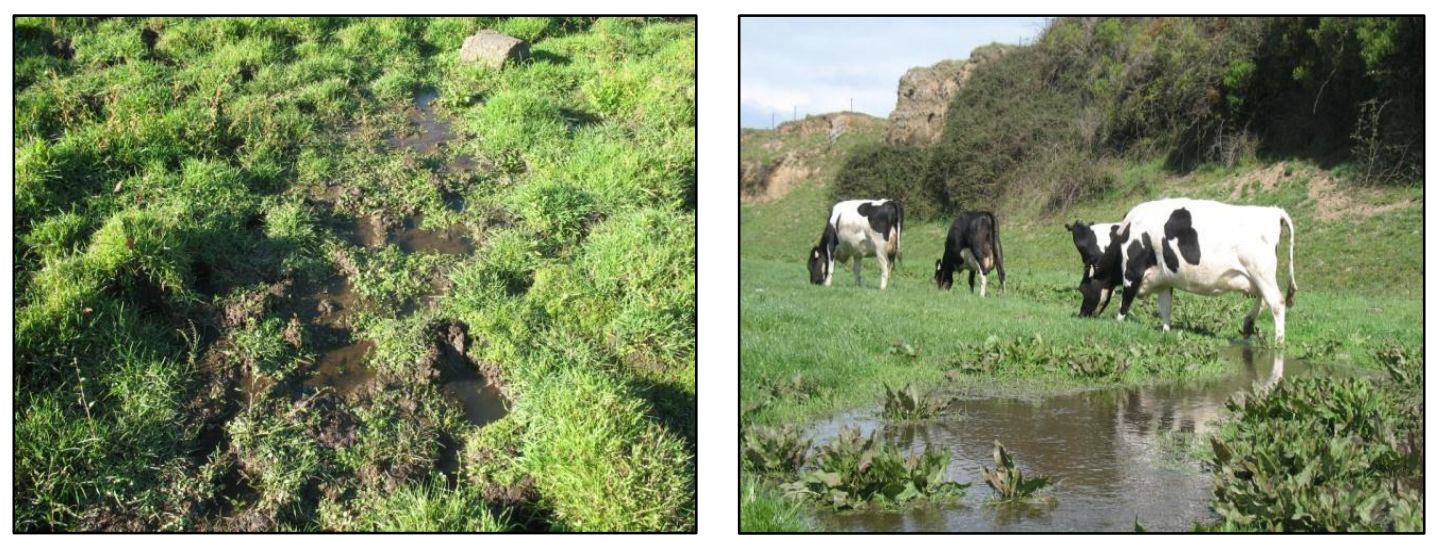

Figure 4.22: Photos showing that cattle trampling along the channel results in loss of a defined channel bank, further influencing the ability of flow to stay within its banks and erode its bed.

A third influence is related to the presence of fine sediment on the channel bed. As it is not being eroded, this fine material acts to reduce infiltration rates on the channel bed, leading to higher levels of pore water in the near channel zone. This is evidenced by the presence of healthy vegetation in these zones throughout the 
dry summer period, the growth of which may be further enhanced by seepage from the adjacent pond (Figure 4.23). The presence of vegetation has a positive feedback effect because stock (if allowed access) will preferentially graze these areas and further trample the channel bed and banks.

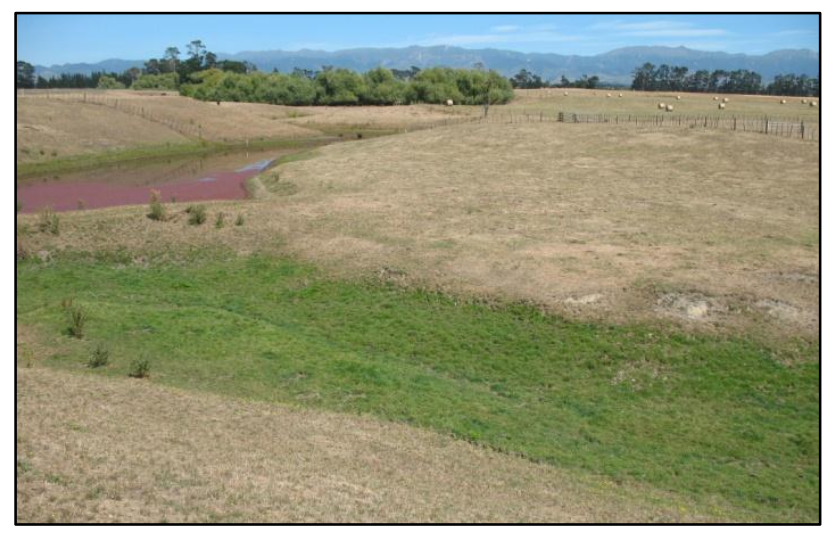

Figure 4.23: Regulated stream channel and surrounding floodplain downstream of Pond C, during the extended period of no streamflow, January, 2009. Healthy vegetation was seen as far as $350 \mathrm{~m}$ downstream of Pond C, indicating the retention of pore water in this zone.

\section{Channel planform}

In temperate climates, channel width and depth on unregulated rivers will increase downstream as discharge increases. On regulated rivers, with changes to the flow regime and a decrease in stream power, width is generally expected to decrease downstream, with depth showing either an increase or decrease (Schumm, 1977). From measurements of channel width, these expected changes hold in the present paired catchment study (Figure 4.23). In the unregulated stream, the width of the active channel increases downstream, whereas the regulated stream shows a narrowing of the channel in the downstream direction. The depth of the channel is indistinct in the regulated stream and could not be measured accurately, so this aspect of channel planform was not investigated further.

The sinuosity of a channel is a measure of the channel length divided by the straight line distance along the channel. After river regulation and the associated decrease in both water and sediment discharge, Schumm (1977) suggested that a 
stream's sinuosity should increase throughout the post-regulation period. Using aerial photographs from 1953 and 1996, sinuosity measurements were calculated for the unregulated and regulated channels. It should be noted that both catchments might have shown some increase in sediment load during this time, as there was an intensification in land use and a decrease in vegetation cover in both catchments throughout this period (as discussed above). The increase in sediment to the system may offset some of the expected change in sinuosity resulting from regulation.

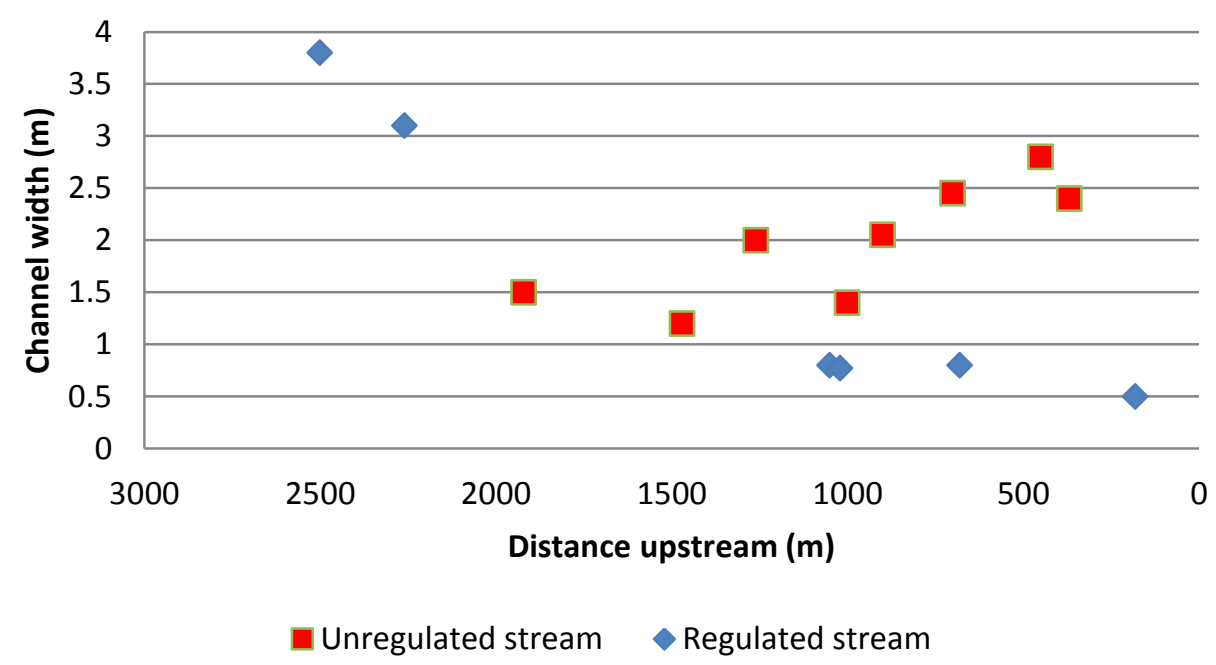

Figure 4.24: Channel width measured at various locations on the unregulated and regulated streams.

In determining sinuosity, the regulated stream's measurement from the 1953 aerial photograph is likely subject to some error because it was difficult to determine the exact location of the stream. The channel location of the unregulated stream was easier to delineate as the channel held water in both the 1953 and 1996 photographs. The unregulated channel had a sinuosity of 1.56 in 1953 and 1.40 in 1996, showing a slight decrease over time. The regulated stream had a sinuosity of 1.50 in 1953 and 1.49 in 1996, showing a very slight decrease, which may suggest that the stream is not yet in an equilibrium state. Because these time slice measures of sinuosity may also reflect the short-term response of the streams to high flow events, direct comparisons between the two catchments should be made with caution. 


\section{Longitudinal profile and knickpoint location}

The longitudinal profile describes the slope of a channel bed from a river's headwaters to its mouth. It is generally included in fluvial studies because it is the "least transient expression of fluvial processes" (Richards, 1982: p. 222) and therefore represents the regime at a longer time scale. Most perennial rivers show a concave upward longitudinal profile (Morisawa, 1968). Longitudinal river profiles are interpreted in how much they depart from a theoretical 'graded' shape: concave upward with no major discontinuities along the river's length. The longitudinal profiles of the unregulated and regulated streams are shown in Figure 4.25. The unregulated stream has a shape closer to the expected graded shape (albeit with some deviations). The regulated stream shows a stronger deviation from the graded concave upward shape.

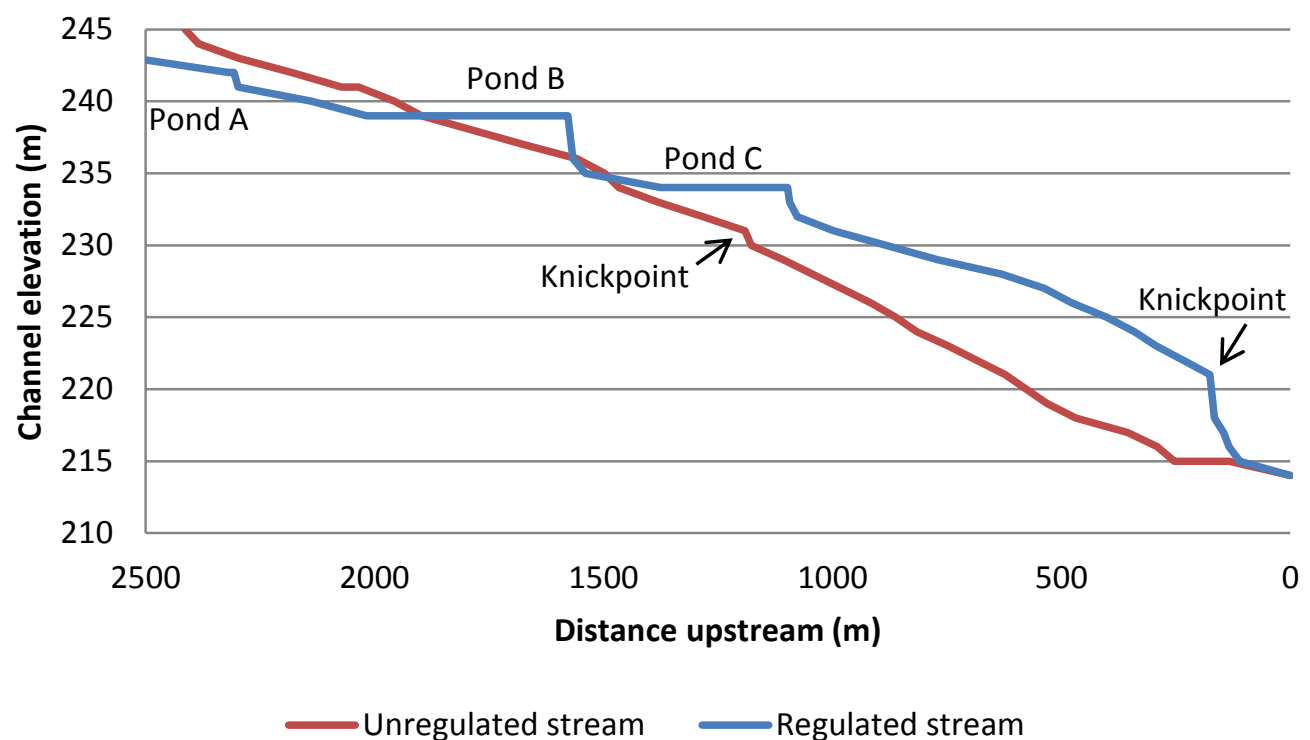

Figure 4.25: Longitudinal profile of the unregulated and regulated streams.

However, a more obvious difference in the profiles is shown by the occurrence of a discontinuity in both streams. A knickpoint represents a sharp drop in streambed elevation as a result of differential rates of erosion along the stream, and will slowly migrate upstream with continued streambed erosion. The rate of upstream migration will be influenced by stream power and the volume of water flowing in the channel. In the study catchments, a difference exists in both 
location and height of the knickpoints. The knickpoint is located $900 \mathrm{~m}$ further upstream on the unregulated channel (Figure 4.25), with a height of $1.2 \mathrm{~m}$ on the unregulated stream and a height of $4 \mathrm{~m}$ on the regulated stream (Figure 4.26).
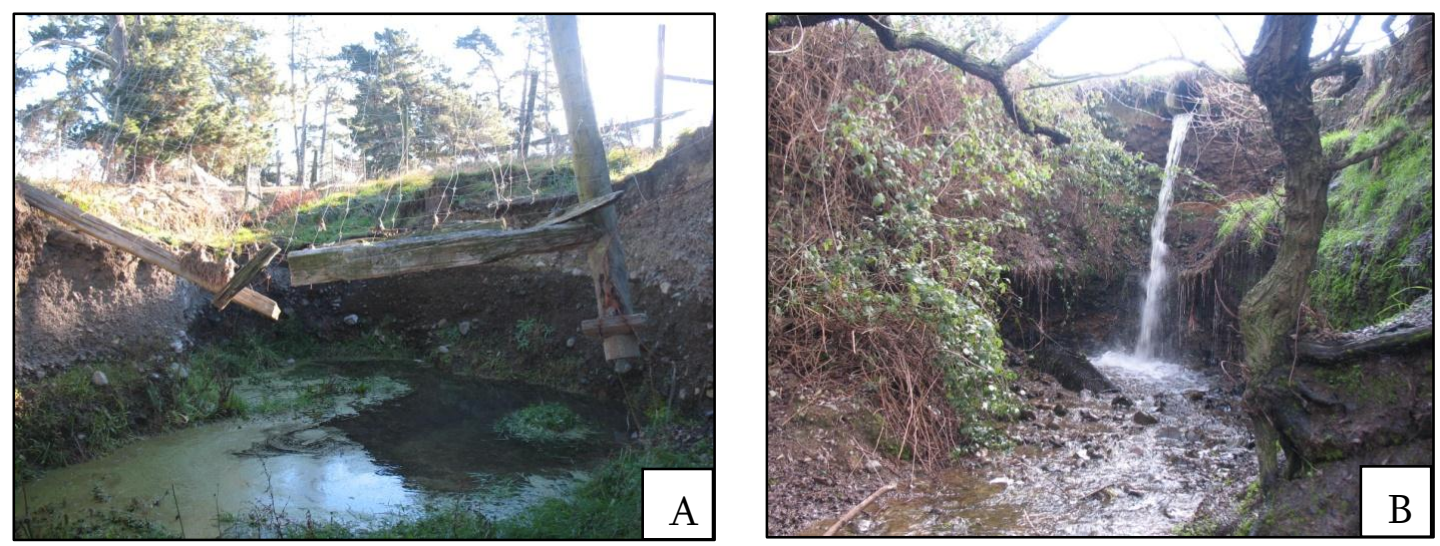

Figure 4.26: A. Unregulated stream knickpoint (1.2 m high) B. Regulated stream knickpoint (4 $\mathrm{m}$ high). The rapid migration of the knickpoint on the unregulated stream is evidenced by the undermining of the fenceposts.

If knickpoint retreat is attributed solely to stream regulation, the average headward erosion rate in the unregulated catchment over the past 40 years (since Pond $\mathrm{B}$ and Pond $\mathrm{C}$ were constructed in the regulated catchment) would be approximately $22.5 \mathrm{~m} / \mathrm{y}$. As this rate is unlikely to be reached in this region, it is probable that retreat has been occurring over a much longer time scale. As well, there may be other factors influencing headward retreat rates, such as local differences in regolith resistance.

Because knickpoint retreat likely began before the construction of dams in the regulated catchment, this observation needs to be viewed in light of the different morphological histories of the two catchments. At some point in the past, there was a truncation of the head of the regulated stream. The new truncated catchment was much smaller than it was previously, and also smaller than the adjacent unregulated catchment. If knickpoint migration had already started in both catchments, this truncation would have led to a lower rate of knickpoint migration due to lower precipitation inputs and lower streamflow levels.

However, high flow events would still be expected in the smaller catchment, and would continue to erode the stream channel. Truncation of the stream may have 
slowed the rate of knickpoint erosion, but it would still have continued its upstream migration.

Therefore, it is likely that the effect of regulation has also had an effect on the rates of knickpoint migration in the two catchments. The unregulated stream has continued to experience high flow events which erode the channel bed, resulting in continuous downcutting and upstream migration of the knickpoint. An attempt to slow knickpoint migration was taken by the landowner in the 1980s when pine trees were planted in the area adjacent to the knickpoint in the unregulated channel. The most recent evidence of this continued migration is the undermining of fenceposts just downstream of the knickpoint (as shown in Figure 4.26A). In comparison, the location and height of the knickpoint on the regulated stream indicates a much slower rate of erosion. In fact, there is no evidence of any upstream migration of the knickpoint at present. As found through the hydrological analysis in the present study, regulation has lowered both streamflow volumes and stream power. Other catchment influences (including channel vegetation growth and stock trampling) have exacerbated this effect. Based on this evidence, it is suggested that regulation has contributed to a slower rate of knickpoint retreat, and that at least some of the difference between the two channels, in terms of knickpoint location and height, can be attributed to regulation.

\subsection{Conclusions of field study}

\subsubsection{Effects of regulation}

\section{Flow regime}

Previous studies have suggested that the regulation of streamflow by small dams will cause a decrease in annual catchment runoff, a shift in the timing of flow, and a lower variability of flow (e.g. McMurray, 2006; Finlayson et al., 2008). In the regulated catchment under study, all of these changes are observed. The 
ponds on the regulated stream delay the beginning of flow in the autumn until ponds are full and overflowing, and also delay the cessation of flow in the spring. The total number of days of measured flow on the regulated stream is double that of the unregulated stream. Flow response to individual storm events is longer on the regulated stream. As well, peak flow volumes are reduced but low flows become more continuous, resulting in a less variable flow regime as compared to the unregulated stream.

The catchment water balance reveals that the unregulated catchment has a higher annual volume of flow, $360 \mathrm{ML} / \mathrm{km}^{2}$ as compared to $216 \mathrm{ML} / \mathrm{km}^{2}$ for the regulated catchment. Assuming catchment equivalence, this represents a streamflow decrease on the regulated stream of $40 \%$. Estimates of pond water losses from evaporation, seepage, and water takes total $39.5 \mathrm{ML} / \mathrm{km}^{2}$ annually. This total volume is greater than the total catchment pond storage volume of 16.6 ML/ $\mathrm{km}^{2}$ and is proportionally much higher than estimated losses reported in previous studies and modelling applications. The difference in annual flow volume between the two systems $\left(144 \mathrm{ML} / \mathrm{km}^{2}\right)$ is higher than the estimated volume accounted for by losses and storage in the regulated catchment $\left(56 \mathrm{ML} / \mathrm{km}^{2}\right)$. The difference may be explained in part by the uncertainty related to the derivation of the level-discharge relationship and the estimation methods used in the water balance calculation. Further field research and a more refined knowledge of catchment processes, especially the interaction between surface water and groundwater, will lead to a better representation of these values. However, the results are considered reasonable, and the overall conclusions are also supported by evidence from the analysis of channel sediment and morphology.

Unfortunately, because of the drier than normal summer and autumn period, a statement cannot be made regarding the presence of flow on the unregulated stream at these times. Storm events do occur throughout the summer, but it is unknown whether or not the unregulated stream normally shows a response to 
these events. If it does, there would be an even greater difference between the two catchments in terms of streamflow volume, because flow is unlikely to occur on the regulated stream during this period when pond levels remain below full and the stream is disconnected.

\section{Water quality}

There is a difference in water quality between the unregulated and regulated catchments, but unfortunately, the low number of samples collected on the unregulated stream means that strong conclusions cannot be made. Water quality levels fell below recommended levels on a number of occasions on the regulated stream (for DO), and within the ponds (for water temperature, $\mathrm{pH}$, and $\mathrm{DO}$ ). This suggests that water quality is more degraded on the regulated stream as compared to the unregulated stream, which had no measurements falling below recommended levels.

A more robust analysis is shown by the changes in water quality from upstream to downstream in the regulated system. A downstream increase in $\mathrm{pH}$ and water temperature is found, along with a decrease in TDS and EC values. Low levels of dissolved oxygen measured at pond outflows return to higher levels as streamflow continues downstream, particularly after water moves past the knickpoint location (with its $4 \mathrm{~m}$ drop in elevation). The most degraded water quality levels measured are within Ponds B and C, especially under the stagnant summer conditions when the stream is not flowing and the ponds are hydrologically disconnected.

It is likely that the regulation of small streams has an effect on water quality, but internal catchment characteristics will determine the magnitude of this effect. It is possible that the influence of the ponds would be lower if they were placed further upstream in the catchment and measures such as DO and stream temperature are able to return to 'normal' levels before leaving the catchment and joining rivers downstream. However, as ponds have been found to act as 
sediment and nutrient traps (e.g. Stanley and Doyle, 2002; Gannon et al., 2005), they might be better placed further downstream in the catchment to enhance this effect. More study will be needed to verify the effects of regulation on water quality and to determine methods of minimising these effects.

\section{Sediment and morphology}

There are marked differences in sedimentologic and morphologic characteristics between the unregulated and regulated streams. This is due in part to the different morphological histories of the streams, in addition to the presence of the three dams on the regulated stream. The post-regulation reduction of peak flow volumes influences stream power, which in turn affects sediment transfer and channel morphology. There is a significant difference in the calibre of channel bed sediment between the two systems. The regulated stream has finer channel bed sediment $\left(\mathrm{d}_{50}=\right.$ fine sand $)$ as compared to the unregulated stream $\left(d_{50}=\right.$ pebble $)$, suggesting that the lower magnitude of regulated flows are unable to transport coarser sediment. Measured suspended sediment concentrations are low at collection times of low to medium flow events, and concentrations show no significant difference between the two catchments. Sediment deposition on the regulated stream is estimated at 1.5 to $2 \mathrm{~cm} / \mathrm{y}$ on average and shows a slight coarsening over the period of regulation. It is speculated that this coarsening is most likely related to the increase in land use intensity and decrease in vegetation cover in the post-regulation period.

There are differences between the two streams in terms of channel planform. The unregulated channel widens in the downstream direction and the regulated channel narrows. A slight decrease in sinuosity is observed in the unregulated catchment. There is a very slight decrease in sinuosity in the regulated channel, but no strong conclusions can be made based on this observation. There is a major difference in the location and height of the knickpoint on both streams, with a knickpoint both lower in height and further upstream on the unregulated 
channel, suggesting a greater rate of channel bed erosion. A decrease in channel erosion on the regulated stream (as compared to the unregulated stream) is attributed to lowered flow volumes and stream power. This change in hydrologic regime occurred over two time periods: first when the stream's head was truncated, and secondly when the stream became regulated. It is likely that the low rate of knickpoint migration on the regulated stream results from a combination of these two events.

There is no evidence of channel scour or channel armouring directly downstream of the dams as has been found in previous studies (e.g. Chilton et al., 2004). The change to the regulated flow regime, in terms of decreased peak flows and total annual flow volumes, may account in part for the lack of channel erosion. However, it is likely that other factors also contribute to this effect, including the deterioration of channel shape and form by stock trampling and instream vegetation. Because the regulated channel does not effectively contain the larger winter flow volumes, the channel bed has never been subject to concentrated flows that would otherwise carve a wider and/or deeper channel. Although there may be other factors influencing the two stream systems, it would still be expected that a new channel (similar to the unregulated channel) would eventually cut down into its bed given the similar climate, geology, and land use of both catchments. This narrower and deeper channel would have higher erosion potentials and the knickpoint would likely have a higher upstream migration rate than at present. By downcutting into the underlying gravels, coarse material would be eroded and moved through the system, coarsening the channel bed deposits (similar to what is observed in the unregulated channel).

\subsubsection{Upscaling results to the regional analysis}

Field studies are generally undertaken at the hillslope or small catchment scale, which is much smaller than the scale at which land and water management decisions are made. Issues surrounding the scaling of field results are numerous; 
processes and patterns that emerge at larger scales are not always seen at the small field scale. Research has demonstrated that many hydrologic processes become nonlinear as they are scaled. For example, recessional response is linear at the hillslope scale but non-linear at the catchment scale (Clark et al., 2009). Temporal scale issues also exist, as short-term studies may be dominated by transient system responses that are at odds with the long-term catchment response (Strayer et al., 2003). Issues of spatial variability across the catchment and representation of this variability have been discussed elsewhere (e.g. Quinn et al., 2004; Clark et al., 2009). Dunn et al. (2008) state that scaling remains one of the most challenging issues in hydrological modelling at present.

The difficulties inherent in scaling have resulted in alternative approaches, including hierarchical modelling and studies of nested catchments. In light of this, no direct scaling between the field study and the regional study will be attempted. Instead, modelling at the regional scale will be informed by field results from the paired catchment study with modelled output assessed for reasonableness of response. Because the paired catchments are located within the larger Tukituki catchment and have similar geology, soil, and climate characteristics, similar runoff responses are expected, and modelled results will be assessed accordingly. 



\section{Regional Study}

The regional study is concerned with prediction of the cumulative impact of farm dams at the larger regional scale. In studying the effect of small dams on catchment systems there are two approaches that can be used. One option is to directly compare pre-dam and post-dam observed streamflow and constituent transfer; however, these data are not usually available. Even when data are available, if farm dam construction is fairly continuous over time, a true 'predam' regime would be difficult to discern. Furthermore, the effect of climate change and other land use change would have an overlapping influence on any differences found and it would be difficult (if not impossible) to remove these influences from the overall record (Neal et al., 2002). An alternative approach is to use a modelling platform to predict streamflow and constituent movement through the catchment, with the incorporation of farm dam storages directly into model simulations (e.g. Argent et al., 2008; Hughes, 2008). This allows for an analysis which is more flexible and powerful in terms of the number of scenarios which can be performed. Although there are also drawbacks to modelling (see Section 5.1 for further detail), it is deemed the best approach for the present study, and the most feasible option given time and cost constraints. Further, the usefulness of a regional scale model is of undeniable importance to the larger question of water management in the area.

Two study areas have been chosen, representing a nested catchment approach. Catchments to be analysed are the Upper Tukipo River catchment (outlet at the Tukipo SH50 gauging site) with a catchment area of $85 \mathrm{~km}^{2}$ and the Upper Tukituki River catchment (outlet at Waipukurau) with a catchment area of $740 \mathrm{~km}^{2}$, of which the Upper Tukipo is a subcatchment (Figure 5.1). To model these catchments, two off-the-shelf models were chosen: Tools for Estimating Dam Influence (TEDI; SKM, 2002) and Source Catchments (eWater CRC, 2010). 
These were chosen after an extensive literature search revealed they were the only readily-available models that incorporate farm dams into the modelling framework. Although building a model specifically for the study catchments might have led to better predictive results, it was assumed that most regional councils would choose off-the-shelf models for water management purposes. As well, a purpose-built model would not necessarily be scalable to other catchments or regions in the country.

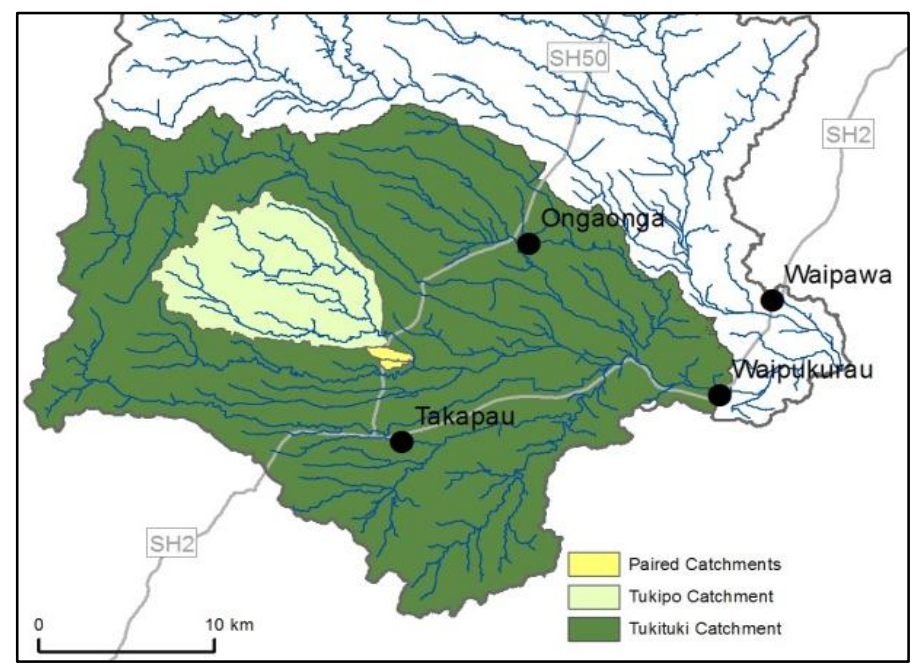

Figure 5.1: Location of the Upper Tukipo and Upper Tukituki catchments used in the regional modelling study.

The two models were run under a number of scenarios to assess the impact of farm dams on streamflow under current catchment conditions, under conditions of future land intensification, and under regional climate change projections. An assessment of the models was made in light of available data and catchment characteristics, to provide guidance on appropriate model structure for use in future investigations. The results of the modelling analysis will therefore be useful to the Hawke's Bay Regional Council (in terms of finding an effective farm dam management model for the area) and might also be a starting point for farm dam study in other areas of New Zealand.

This chapter will begin with a short background on modelling, followed by a review of the TEDI and Source Catchments models, details of model setup, and 
derivation of all input values. Results of model runs for the two study catchments will conclude the chapter.

\subsection{General Modelling Overview}

Models are simplified approximations of real-world systems. Model types (empirical, conceptual, physical, or a mixture thereof) are chosen based on available data and the objectives of the modelling exercise. Empirical models derive a relationship between measured catchment inputs and outputs without attempting to describe the processes or interactions occurring amongst variables. Conceptual models represent processes deemed important in the catchment in a simplified manner, often involving simulation through a series of interlinked processes and storages within the catchment. Physical models are based on the governing equations of water flow and the fundamental physics which describe the processes acting upon and within a catchment (Mulligan and Wainwright, 2004). A further delineation of models can be made based on whether inputs and outputs are averaged across the catchment (lumped) or if they are allowed to vary spatially (distributed). Temporal resolution can also be averaged over long time periods or resolved into much smaller time steps. A further distinction comes through the way model predictions are treated; whether they are output as single

values (deterministic) or are represented by probability distributions of potential model outcomes (stochastic).

Although the type of model chosen has a significant impact on results, studies have determined that there is not always one model type that should be used preferentially. For example, Breuer et al. (2009) compared 10 lumped, semilumped, and fully distributed rainfall-runoff models that had been used to model land use change in the same catchment in Germany. They found that although conceptual models generally outperformed fully distributed physically-based ones, there was no superior model type that should be chosen above all others. 
Existing (off-the-shelf) models have a variety of applications and strengths. Some existing models are developed for specific sites and should not be transferred to dissimilar areas, while others have been designed to be of general use in numerous contexts. The temporal and spatial resolution of the model must also be appropriate to the data available. Although a more complex model may better represent catchment processes, it will almost always come at the cost of added processing time and uncertainty in model predictions (Croke and Jakeman, 2008). Advice in choosing an appropriate model is to use the simplest model that will do the job required (e.g. Steefel and Van Cappellen, 1998).

The concept of uncertainty is extremely important in any modelling scenario. Models are fundamentally compromises because they are simplified and imperfect representations of reality. Uncertainty can be minimised by using the most accurate input data available, by basing the model on proper theoretical and physical concepts, and by evaluating all potential sources of error (CRC for Catchment Hydrology, 2005).

One point of uncertainty comes through the quantification of model input. In physically-based modelling, it is often problematic to assign representative values for all input parameters, either because they are difficult to physically measure or because representation is difficult due to temporal and/or spatial heterogeneity. Scale issues are also important to address, as hydrologic processes span many orders of magnitude in space and time (Klemes, 1983), with spatially variable parameters varying at different scales (Wood et al., 1988). Model calibration is used to modify input parameters by comparing modelled output to direct observations made at the study catchment. The measure of 'goodness of fit' shows how well the model fits this set of observations. Adjustments to parameter values are made manually or automatically until an acceptable goodness of fit measure is found. One method to refine input parameters is to sample them from a range of feasible values with a likelihood measure evaluated after each stochastic model simulation (e.g. GLUE; Beven and Binley, 1992). The sensitivity of input 
parameters can first be ascertained in order to determine the sensitivity of model output to changes in each parameter (Mulligan and Wainwright, 2004). By focusing calibration on the most sensitive parameters, small adjustments can be made, thereby ensuring that sensitive input parameters have the highest possible accuracies to minimise errors in model output.

In any modelling analysis, uncertainty will be present even in the case of the 'best' representation based on the 'best' data (Soulsby et al., 2008). An important aspect of modelling is an uncertainty analysis which estimates the uncertainties in model structure, parameter values, and/or data. In effect, this will seek to show how well the model answers the questions that are being asked (Argent et al., 2008). Even so, error will be hard to reduce in instances where nonstationarity exists in the catchment (e.g. land use change through time) or where boundary conditions are continuously changing (e.g. under climate change) (Breuer et al., 2009). The combination of potential errors associated with model input and the complicated transformation of these errors through often non-linear model functions results in a very complex modelled output (Beven, 2008). If management decisions are based on these outputs, it is important that these decisions are communicated within this broader context of uncertainty.

\subsubsection{Modelling runoff}

Runoff generation processes are non-linear and vary spatially and temporally, so difficulties exist in the incorporation of these processes into modelling platforms. Typically, rainfall-runoff models are based on a water balance approach. Outflow is predicted using inputs of rainfall and losses to evapotranspiration, with flow routed through a number of surface and subsurface pathways to the catchment outlet. The differences amongst the various rainfall-runoff models arise primarily from the way flow generation processes are represented, including the choice of governing flow equations and the number of storages and flow pathways represented within the catchment. 
The runoff processes thought to be most significant in the study catchments are storm runoff processes, most significantly saturation excess overland flow from variable source areas. There is a low baseflow contribution. Soils in the region have high infiltration capacities, so infiltration excess mechanisms are likely not important except in localised areas (e.g. where soil is compacted by stock trampling or on farm tracks). Subsurface stormflow may also reach the stream rapidly through macropore flow or through the displacement of pre-event water through the soil matrix (Burt, 1996), although these routes are generally not modelled explicitly in off-the-shelf models (Beven, 2001).

\subsubsection{Modelling sediment and water quality}

Sediment and water quality models generally have some combination of predicting the location of generation areas, along with the subsequent transport of sediment, nutrients, and other constituents through the catchment. These models may also include representations of instream mixing and dilution. When the purpose of modelling is to investigate the effect of land use change on constituent output from the catchment, Elliott and Sorrell (2002) suggest that most models are better at predicting relative effects of land use or land management rather than absolute derived loads. This is because of the lack of direct observations to properly calibrate and validate the model, coupled with the difficulty of fully representing the complexity of processes involved. Therefore, the most common method for modelling constituent generation and movement is by using a mass balance approach, resulting in the determination of general catchment response rather than a specific quantification of exact processes at exact times (e.g. CRC for Catchment Hydrology, 2005).

Sediment models focus on suspended sediment and generally do not incorporate bedload. This is justified by the fact that bedload is generally a smaller fraction of total sediment load, although the omission of bedload is also likely a reflection of the difficulty in its quantification (Hicks and Gomez, 2003). Even so, the 
modelling of suspended sediment generation and movement is still problematic. Not only are suspended sediment concentrations dependent on catchment characteristics (including soil, geology, runoff processes, and precipitation volume, intensity, and timing), the scale of the catchment under study is also important. Sediment output per unit area from a catchment tends to decrease as the size of the catchment increases because extra storage is available within the catchment itself (Walling, 1983). However, the relationship between sediment yield and catchment size is not simple, nor is it linear. Furthermore, the temporal scale of the study is important because catchment sediment yield may be subject to large time lags between the timing of sediment generation and its transfer through the catchment.

Ideally, this study would use a spatially distributed constituent transport model (which includes both suspended sediment and nutrients) to model subcatchments and stream segments individually. Routing algorithms would be incorporated to predict the timing and volume of constituent transport through the catchment. Unfortunately, TEDI does not include the modelling of sediment transfer and constituent routing. Although Source Catchments does include these components, it recommends that constituent routing not be applied when routing water through farm pond storages, as the model is not able to account for constituent routing through the storage ponds. Therefore, the present modelling analysis will deal solely with the influence of farm ponds on runoff volumes.

\subsection{Models specifically designed for farm dams}

The Tools for Estimating Dam Impacts model (TEDI; SKM, 2002) is a lumped catchment model which gives a prediction of farm pond influence on monthly streamflow volumes. It is widely used in Australia for catchment water management. Source Catchments (eWater CRC, 2010) is the only off-the-shelf spatially distributed model that predicts catchment-scale effects of farm dams on streamflow. It is run on a daily time step. Comparisons between TEDI and Source 
Catchments will be made based on the different temporal and spatial scales used in each model (i.e. monthly to daily time step, and lumped to distributed spatial scale). Both models will be discussed in greater detail below before being applied to the Upper Tukipo and Upper Tukituki study catchments.

\subsubsection{Tools for Estimating Dam Impacts (TEDI)}

TEDI is a spatially lumped water balance model calculated on a monthly time step. A water balance is applied to each dam in the catchment, after which impacts are combined to predict their total impact on streamflow (Lowe and Nathan, 2008). The model is used to predict the impact of current catchment farm dams on the natural flow regime, as well as the effect of future development scenarios on the current flow regime. The model has been used extensively in Australia for the purposes of catchment water management and is a standard tool in Victoria, Australia for quantifying water stored in farm dams (Nathan et al., 2005). No literature has been found to indicate its use outside of Australia.

Inflow to each farm pond or reservoir is assumed to be linearly proportional to dam catchment contributing area, which in turn is assumed to be linearly proportional to the size of the dam. Dam outflow is added to streamflow, with no accounting for either the spatial distribution of dams within the catchment or for channel transmission losses. Within the water balance calculation, seepage from the pond is assumed to be negligible. Inputs to the model include average monthly catchment rainfall and evaporation, total volume of existing dams and additional future dams, average monthly takes from dams, distribution of catchment dam sizes, proportion of dams with bypass facilities, and catchment areas corresponding to dams of $5 \mathrm{ML}$ and $100 \mathrm{ML}$ volume. This last input is used to determine the upstream catchment area of dams between $5 \mathrm{ML}$ and $100 \mathrm{ML}$ using linear interpolation between these two values. A time series of catchment streamflow is used to model baseline or 'natural' conditions (i.e. catchment flow 
with no dams). Derived flow from TEDI modelling is compared to these baseline conditions to ascertain the reduction in flow caused by farm dams.

There have been a number of criticisms of this model. As it was designed for ease of use, its simplicity has meant that all assumptions may not be valid. To test some of these assumptions, Nathan et al. (2005) developed a model with the same underlying form as TEDI, but to which hydrological complexity could be added progressively. In this manner, each assumption could be tested in turn for its effect on the overall predictive capability of TEDI. The developed model allowed for connected dams, discrete dam volumes, non-linear scaling of streamflow, user specified dam catchment contributing areas, and an iterative rather than additive solution for the calculation of natural streamflow. After testing the model on three catchments of moderate to high levels of farm dam development in Australia, it was found that the most problematic assumptions were those of natural streamflow derivation and dam catchment contributing area (Nathan et al., 2005). Natural flows were better estimated during high flow months and were underestimated during periods of lower flow (below median). They concluded that the assumption regarding farm pond connectivity (where all ponds are considered spatially separate and outflow from each is directed separately to the catchment outlet) had a negligible effect on natural flow estimates (Nathan et al., 2005). However, the influence of ponds on catchment flow volumes will depend on the actual number of connected ponds in the catchment and the seasonal timing of fill and spill of the ponds. Where connected ponds exist, the first spill of the season may be caught in the successive pond, thereby delaying flow to the main channel. If the ponds fill quickly, this will have a minor effect in reference to the model's monthly time step; however, the spatial distribution of the ponds may become more significant if the model were run at time steps finer than one month. Despite this, they concluded that TEDI "provides a defensible estimate of the impact of farm dams on streamflows, particularly for catchments with low to moderate levels of farm dam development" (Nathan et al., 2005: 10). In 
comparing modelled results to observed field data from three catchments in Australia, they are more cautious in 'tentatively' concluding that the TEDI assumptions have a small influence on results (Nathan et al., 2005).

Uncertainties in farm dam inputs to the TEDI model were also studied by Lowe and Nathan (2008). They applied a theoretical statistical distribution of uncertainty to each farm dam characteristic (based on estimates from prior regional studies) and then ran the TEDI model using data from a catchment in Victoria, Australia. Mean input values relating to each farm dam characteristic were randomly chosen from theoretical distributions (which were fit to the sample catchment data) by means of a Monte Carlo simulation. After 1000 simulation runs, the results showed that the volume of farm dams varied by $\pm 11 \%$ of the population mean and the impact on streamflow varied by $\pm 29 \%$. As only mean values from the theoretical distributions were input for each run, it should be noted that the intra-dam variability of each characteristic may further impact these results. Their results showed that the highest uncertainty came from the estimation of dam catchment contributing area, echoing the finding of Nathan et al. (2005). In order to decrease this source of uncertainty, Lowe and Nathan (2008) suggest using spatially explicit dam catchment areas derived from topographic maps rather than using regional estimates.

The fact that TEDI assumptions were tested on only four catchments (over the two studies) suggests that there may be a need for further research regarding TEDI model assumptions. In fact, Nathan et al. (2005) suggested that more catchments should be tested, especially those with pronounced periods of low to no flow, where TEDI may underestimate farm dam impacts on catchment streamflow.

\subsubsection{Source Catchments}

A suite of models has been developed by eWater CRC (formerly CRC for Catchment Hydrology, Australia) to estimate flow, sediment, and nutrient loads 
under scenarios of changing land use and climate. The most recent model is Source Catchments (eWater CRC, 2010), which is primarily intended to help inform catchment managers regarding the influence of management plans on the quantity and quality of runoff. Source Catchments incorporates sediment, nutrient, and water quality modelling of rural and peri-urban catchments and can be run on a range of catchment sizes, optimally between 1 and $5000 \mathrm{~km}^{2}$ (Argent et al., 2008). It is intended to be used by experienced hydrologic modellers able to identify the best model components to use based on data requirements, catchment characteristics, and uncertainty constraints.

In Source Catchments, a number of component models can be chosen and linked in a manner that corresponds to specific catchment characteristics and modelling objectives. Component models include rainfall-runoff models, constituent generation models, filtering algorithms, and instream and reservoir routing models. The same component model does not need to be used throughout the entire catchment, so by dividing the area into smaller subcatchments, the user can apply component models to these subcatchments based on specific internal characteristics and derive model output at any point within the catchment. At the subcatchment level, the model can be further delineated based on functional units, nodes, and links. Functional units are delineated based on areas with a common hydrologic response or behaviour. Generation of flow and constituents occurs within each functional unit, along with filtering functions which allow for the integration of management treatments such as riparian filter strips or artificial wetlands. Generated flow and constituents then pass through nodes which are situated at all subcatchment outlets and other user-defined locations such as stream confluences or dam walls. Water management information including extractions and demands can be incorporated at node locations. All nodes are connected by links, through which water and constituents are routed and wherein storage and/or processing of material can occur. However, because of uncertainties involved in modelling constituent 
concentrations and movement through storage ponds, it is not recommended to model both of these components at the same time (eWater CRC, 2010).

Farm dam storages can be incorporated into the model either within the flow routing function at the link configuration, or within the filtering step. The link configuration is recommended if a spatially explicit representation of farm dams is required, because farm dam modelling using the other option (i.e. within the filtering step) uses a semi-lumped approach (eWater CRC, 2010). In the link configuration approach, farm dams are placed at node locations, with the immediate upstream link representing the reservoir where processing or storage of material occurs. In this manner, multiple dams on the same stream can be modelled, although this would require more time for pre-processing the data. The second method for incorporating farm dams into Source Catchments is within the filtering step. This option is based on TEDI model principles, although at a finer spatial scale and at a daily time step. Information is input at the subcatchment level, allowing each subcatchment and functional unit to have a different farm dam density and farm dam characteristics as required. However, dams are still lumped at this finer spatial level and the model does not allow routing through ponds on the same stream (i.e. outflow from each dam in the subcatchment flows directly to the next downstream subcatchment). Inputs are the same as for the TEDI model, including total density of dam volume per subcatchment area, storage volume of each pond, dam catchment contributing area, a pond surface area-volume relationship, and water demand for stock and irrigation use. As with TEDI, a sample of farm dams is stochastically generated for model predictions based on input farm dam density and size class distributions. The model also calculates direct rainfall on and evaporation from the pond surface, with pond seepage assumed negligible.

For the present study, farm dams will be modelled using this second approach, which is based on TEDI model principles, but is at a finer temporal and spatial scale. Although modelling farm dams using the first approach (within the link 
function) and routing water through each dam individually would be more precise, the input data needed for this approach are not available. This would require detailed input information including stream and groundwater inputs and losses for each pond, water discharge at various pond depths, and a minimum and maximum outlet capacity table. None of this information is readily available and it is likely that the precision gained in using this approach would be lost in the generalisations necessary to produce the input data.

An additional difference in modelling using Source Catchments is that it allows for streamflow representation in terms of rainfall-runoff modelling (which is not available in TEDI). Although six rainfall-runoff models are available within Source Catchments, only the Australian Water Balance Model (AWBM) was deemed to adequately capture the important runoff components within the study catchments. AWBM is suitable for permeable catchments with low (or no) infiltration excess overland flow. It is a conceptual mass balance model and contains three surface stores which represent partial areas of runoff, and which are calculated independently with additions of precipitation and deductions of evapotranspiration made at a daily time step (Boughton, 2004). Any surplus from the stores generates both surface runoff and baseflow recharge; the division between the two is set by the baseflow index (BFI). Baseflow recession is also set by the user (K $\mathrm{K}_{\text {base }}$ ). A surface runoff routing store can be set to represent a delay of surface runoff reaching the outlet (generally used for medium or large-sized catchments). Daily values of precipitation and actual evapotranspiration are input and the model outputs daily surface flow and baseflow (Boughton, 2004). Calibration of the AWBM model and parameters derived for each study catchment are described in Section 5.3.7.

\subsection{Model Components}

Before the TEDI and Source Catchments models can be applied to the study catchments, a number of input parameters must be derived and pre-processing 
steps undertaken. These will be described below and include hydrologic inputs, farm pond characteristics and demand inputs, DEM derivation, and calibration of the AWBM model.

\subsubsection{Water balance inputs}

Precipitation data are required for TEDI (monthly) and Source Catchments (daily). For the Upper Tukipo catchment, catchment precipitation was derived using data from three precipitation gauges: Tukipo SH50 (located at the catchment outlet), Makaretu North (located mid-catchment), and Moorcock (located just outside the top of the catchment). For the Upper Tukituki catchment, six precipitation gauges located across the catchment were used, including Mt. Vernon at the catchment outlet, Flemington and Ongaonga at midcatchment locations, and the three gauges used in the Upper Tukipo analysis (Figure 5.2). In both data sets, precipitation data from 1999 to 2009 were integrated across the catchment using the Thiessen polygon method with missing values infilled using data from nearby gauges. Missing data amounted to less than 3\% (109 days) of the total data at Moorcocks and Makaretu North sites, while the four other stations had missing data of $0.14 \%$ (5 days) or less.

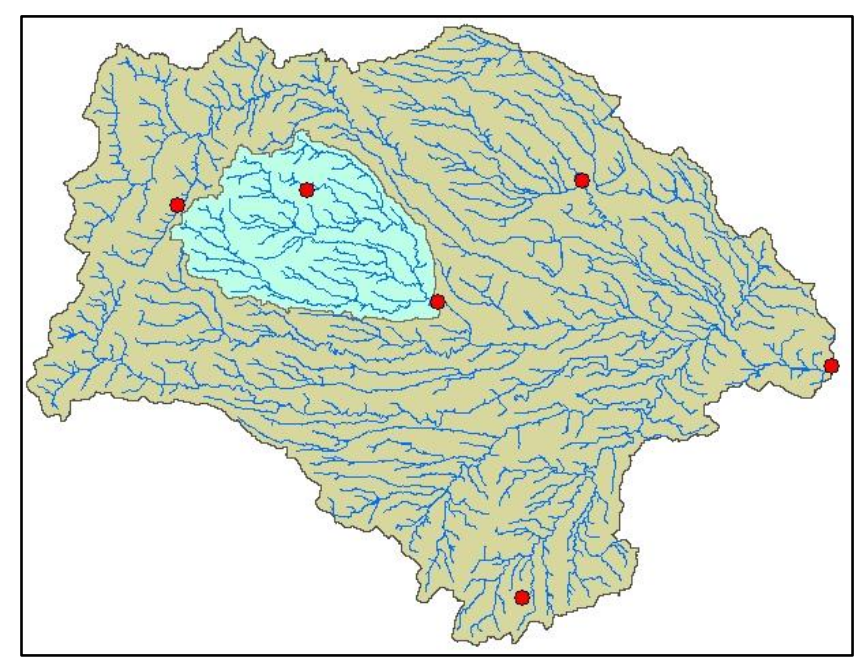

Figure 5.2: Location of precipitation gauges used for derivation of catchment precipitation for the Upper Tukipo and Upper Tukituki catchments. 
Daily and monthly potential evapotranspiration values (PET) are also required as input to both models. PET has been collected at the Ongaonga climate station since 2007. A relationship was derived between PET values from Ongaonga and those from the Dannevirke climate station (located $25 \mathrm{~km}$ south of the Tukituki catchment boundary) in order to extend this data set back to 1999. The relationship is:

$$
\mathrm{O}_{\mathrm{PET}}=0.8116 \mathrm{D}_{\mathrm{PET}}+0.7294
$$

where OPET $=$ Ongaonga PET $(\mathrm{mm} / \mathrm{d})$ and DPET $=$ Dannevirke PET $(\mathrm{mm} / \mathrm{d})\left(\mathrm{R}^{2}=\right.$ 0.84). Derived PET values were used for both the Upper Tukipo and Upper Tukituki catchments (i.e. the same values were used in both catchment analyses), as evapotranspiration has been found to vary insignificantly across the Hawke's Bay region (HBRC, 2003).

The rainfall-runoff component model (AWBM) used in Source Catchments requires actual evapotranspiration (AET) values, so derived PET values were adjusted accordingly. This was completed using soil moisture deficit data from Ongaonga (1999 - 2009), a field capacity measure of $150 \mathrm{~mm}$, and a stress point of $50 \mathrm{~mm}$ (values which are routinely used by HBRC). When soil moisture levels equal field capacity, AET equals PET, and when soil moisture levels are less than or equal to the stress point, AET is given a value of $0 \mathrm{~mm}$. Between these two situations, AET is calculated as a proportion of PET using:

$$
A E T=\frac{S M}{150} P E T
$$

where $S M=$ soil moisture deficit and all variables are measured in $\mathrm{mm} / \mathrm{d}$. As with PET values, derived AET values were used for both the Upper Tukipo and the Upper Tukituki catchments.

Daily stream discharge records are available for the Upper Tukipo catchment outlet (Tukipo @ SH50 gauging site) and the Upper Tukituki catchment outlet (Tukituki @ Waipukurau gauging site) for the entire period of study (1999-2009). 
Missing data represent less than $0.5 \%$ (4 to 9 days) of the total study period for both rivers. Missing data were infilled based on measured flow trends surrounding the period of missing data. Daily streamflow volumes were summed for input as monthly streamflow volumes for TEDI. Catchment runoff is not required for Source Catchments, but the daily time series for both rivers was used to calibrate AWBM, the component rainfall-runoff model used within Source Catchments.

\subsubsection{Number and areas of ponds}

Previous studies have outlined methods for calculating catchment dam numbers using manual or automatic approaches (or a combination of the two). The exact method chosen will depend on available data and computational requirements. Gutteridge Haskins \& Davey (1987) found that aerial photographs with a scale of 1:25,000 were insufficient to capture ponds $<2500 \mathrm{~m}^{2}$ in area, a size which represented $98 \%$ of all stock and domestic ponds in their study catchment. A recommended scale of 1:10,000 was suggested by both Maxted et al. (2005) and McMurray (2006) for farm pond delineation. When aerial photographs are digitally scanned, pixel sizes close to $1 \mathrm{~m}$ can be derived (Dare et al., 2002). At these resolutions, manual digitisation of small ponds can be made quite accurately with a lower cost of data acquisition, albeit a higher cost in terms of time.

Alternatively, at a higher initial cost, high resolution satellite images and LiDAR data can be obtained and used to extract pond data automatically. Although automatic retrieval of pond locations is possible, the delineated ponds often need to be manually checked to ensure that they do not include other types of water bodies such as natural lakes or tailings dams. The combination of automatic pond retrieval and manual calibration or validation has been used by the MurrayDarling Commission (2008), Dare et al. (2002), and Mialhe et al. (2008).

In automatic extraction methods for satellite data, the spectral signal of water can be separated from that of the surrounding land because of the unique nature of 
radiation reflection and absorption by water (Finch, 1997). In these cases, the near infrared band is used to distinguish between open water and surrounding land, and the visible red band is used to further separate water from soil (Liebe et al., 2005). Some error is introduced in areas of high shadow such as mountainous regions and also in instances where water is not completely clear (e.g. water with a high suspended sediment load or algae cover). Variability will also exist if ponds are not full of water at the time of image acquisition (Lowe et al., 2005).

High resolution topographic LiDAR data can be used to automatically locate ponds by finding depressions in the landscape. This does not require ponds to be empty, although an extra sensor is needed to collect data through any depth of water (Irish and Lillycrop, 1999). Along with the red (infrared) beam used to collect topographic data, a blue-green beam is used to collect hydrographic data. Water can be measured up to a $70 \mathrm{~m}$ depth in clear water, but refraction and scattering of the return signal will occur in water that is not clear, thereby limiting the depth of measurement. The extra cost in procuring and using this hydrographic sensing equipment often precludes its use. In some areas, LiDAR runs have been made when ponds are empty or near-empty and this has proven successful (e.g. study of urban detention ponds in Texas by Liu and Wang, 2008). In the present study, a number of pond counting methods were attempted. A national lakes layer (derived from the New Zealand 1:50,000 topographic map series) is available, but the coarse resolution of the layer led to there being only 67 ponds located in the Upper Tukipo catchment, as compared to the 453 ponds that were manually digitised at a finer resolution (as described below). Therefore, although it is readily available, it is not recommended that the lakes layer dataset be used, as the pond numbers will be greatly underestimated. An attempt was also made to automatically delineate farm ponds from 1:5000 scale digital aerial photo and satellite images. Although these techniques have been used successfully in other regions, it was not possible to replicate known methods at the scale required for the present study. Resolution of the Landsat images was too 
coarse and aerial photographs had too variable a colour signature for automatic classification to be completed. Higher resolution KiwiImage satellite data $(0.6 \mathrm{~m}$ pixel size) were available, but the images were taken during a very dry summer period and many of the ponds were empty or near empty. This meant that image separation techniques could not be used as the water signature could not be defined. Topographic LiDAR data for the study catchment does exist, but its acquisition did not include the hydrographic data sensor, so it could not be used to determine pond locations or sizes.

Therefore, pond delineation was completed by manually digitising KiwiImage digital images using ESRI ArcGIS software. A scale of 1:4000 was used to first locate the ponds, which were then manually digitised at a finer resolution. Because images were taken during the dry summer period and pond water levels were below full capacity, maximum pond dimensions were estimated using adjacent vegetation and bank erosion features. Pond areas were calculated automatically from the digitised data using ArcGIS geometry tools. Figure 5.3 shows the location of all ponds (onstream and offstream) digitised in the Upper Tukipo catchment.

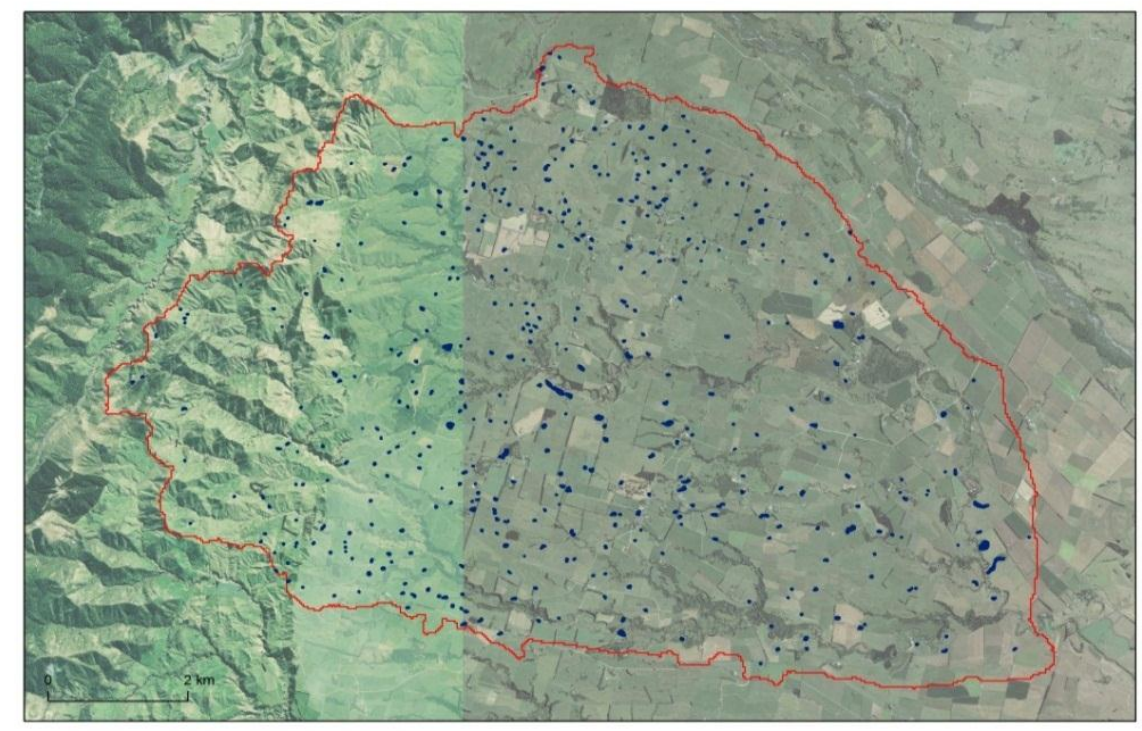

Figure 5.3: Manually digitised ponds located in the Upper Tukipo catchment. 
An error analysis of manual digitisation techniques was undertaken. It was determined that the introduction of digitisation errors could occur in pond size (operator error), omission (ponds that exist but were not digitised), and commission (ponds that were digitised but do not represent ponds). To test operator error, 16 ponds were chosen randomly and each was digitised 5 times. Overall, an average operator error of $\pm 1.8 \%$ of total pond area was found (range 0.2 to $5.3 \%$ ). A comparison of digitised ponds in the Upper Tukipo catchment to the nationally available lakes layer revealed that of a total of 67 lakes in the catchment, only five were not captured by the manual digitisation process $(7 \%$ of total), and all of these were completely empty of water in the image. Errors of commission were not analysed as this would have entailed an extensive ground truthing analysis. Overall, it was assumed that the three types of error will not have a significant effect on subsequent model runs.

\subsubsection{Pond volumes}

Both models require a quantification of the volume of water stored in ponds within the study catchments. Pond volume information is not readily available as regional councils in New Zealand only have information on ponds which require resource consent. As it is unrealistic to physically measure the volume of every pond, an alternative method of derivation is required. In previous studies, the most common method to determine pond volume is to measure the areas and volumes of a subset of ponds and use these values to develop an area-volume relationship to apply to the rest of the ponds in the catchment (McMurray, 2004). Although this method has been found to be inaccurate in determining volumes of individual ponds, it has been found to be relatively accurate when total volumes are calculated for catchments (McMurray, 2004). Alternative methods of volume derivation include using measured surface areas in conjunction with geometric shape indices (e.g. Liebe et al., 2005) or pond depth measures (e.g. Taube, 2000), 
but given the available data, these methods were not investigated further at present.

Area-volume equations have been developed for numerous farm dam studies, and similar equations exist for the estimation of prairie pothole volumes in regions of North America (e.g. Wiens, 2001; Gleason et al., 2007). A sample of area-volume equations used in previous farm dam studies is summarised in Table 5.1, with a comparison of these equations shown in Figure 5.4 using a pond area of $5000 \mathrm{~m}^{2}$.

Table 5.1: Derived area-volume equations from previous studies. In all cases, $\mathrm{V}=$ volume $\left(\mathrm{m}^{3}\right) ; A=$ area $\left(\mathrm{m}^{2}\right)$. The reference number links the equations to Figure 5.4.

\begin{tabular}{|c|c|c|c|}
\hline $\begin{array}{l}\text { Area - Volume } \\
\text { Relationship }\end{array}$ & $\begin{array}{l}\text { Ref } \\
\#\end{array}$ & Method and Location of Derivation & Reference \\
\hline $\begin{array}{l}V=0.0016 A^{1.56} \\
V=0.077 A^{1.3}\end{array}$ & $\begin{array}{l}1 \mathrm{a} \\
1 \mathrm{~b}\end{array}$ & $\begin{array}{l}\text { Two catchments, different } \\
\text { relationships attributed to differences } \\
\text { in geographical relief; South Africa. }\end{array}$ & $\begin{array}{l}\text { Maaren and } \\
\text { Moolman, } 1985\end{array}$ \\
\hline $\mathrm{V}=0.187 \mathrm{~A}^{1.25}$ & 2 & $\begin{array}{l}18 \text { pond volumes up to } 100 \mathrm{ML} \\
\text { measured; Australia. }\end{array}$ & $\begin{array}{l}\text { Srikanthan and } \\
\text { Neil, } 1989\end{array}$ \\
\hline $\mathrm{V}=0.0738 \mathrm{~A}{ }^{1.25}$ & 3 & $\begin{array}{l}15 \text { of } 305 \text { small ponds measured; } \\
\text { Botswana. }\end{array}$ & $\begin{array}{l}\text { Meigh, 1995; } \\
\text { Finch, } 1997\end{array}$ \\
\hline $\mathrm{V}=0.2 \mathrm{~A}^{1.2604}$ & 4 & $\begin{array}{l}\text { Methodology not documented; } \\
\text { Australia. }\end{array}$ & $\begin{array}{l}\text { Pikusa, 1999; } \\
\text { Savadamuthu, } \\
2003\end{array}$ \\
\hline $\mathrm{V}=0.44 \mathrm{~A}^{1.4}$ & 5 & $\begin{array}{l}26 \text { pond volumes of }<2-39 \mathrm{ML} \\
\text { measured; Australia. }\end{array}$ & McMurray, 1996 \\
\hline $\begin{array}{l}V=1.6 A-108.6 \\
V=3.5 A-5742.5\end{array}$ & $\begin{array}{l}6 \mathrm{a} \\
6 \mathrm{~b}\end{array}$ & $\begin{array}{l}\text { A }<3000 \mathrm{~m}^{2} \text {, high irrigation demand. } \\
\text { A }>3000 \mathrm{~m}^{2} \text {, high irrigation demand. } \\
100 \text { ponds mostly }<50 \mathrm{ML} \text { measured; } \\
\text { Australia. }\end{array}$ & $\begin{array}{l}\text { Billington and } \\
\text { Kotz, } 1999\end{array}$ \\
\hline $\mathrm{V}=0.1757 \mathrm{~A}^{1.2731}$ & 7 & 42 ponds measured; Australia. & SKM, 2001 \\
\hline $\begin{array}{l}\mathrm{V}=16 \mathrm{~A} \\
\mathrm{~V}=20 \mathrm{~A}\end{array}$ & $\begin{array}{l}8 \mathrm{a} \\
8 \mathrm{~b}\end{array}$ & $\begin{array}{l}\text { Low relief, ponds }<50,000 \mathrm{~m}^{2} \text {. } \\
\text { Hilly relief, ponds }<50,000 \mathrm{~m}^{2} \text {; South } \\
\text { Africa. }\end{array}$ & $\begin{array}{l}\text { Pitman and } \\
\text { Pullen,1989 }\end{array}$ \\
\hline $\begin{array}{l}\mathrm{V}=2 \mathrm{~A}^{1.25} \\
\mathrm{~V}=2.2 \mathrm{~A} \\
\mathrm{~V}=0.215 \mathrm{~A}^{1.26} \\
\mathrm{~V}=2.8 \mathrm{~A}\end{array}$ & $\begin{array}{l}9 \mathrm{a} \\
9 \mathrm{~b} \\
9 \mathrm{c} \\
9 \mathrm{~d}\end{array}$ & $\begin{array}{l}\text { Low demand; } A<15,000 \mathrm{~m}^{2} \\
\text { Low demand; } A \geq 15,000 \mathrm{~m}^{2} \text {. } \\
\text { High demand; } \mathrm{A}<20,000 \mathrm{~m}^{2} \text {. } \\
\text { High demand; } \mathrm{A} \geq 20,000 \mathrm{~m}^{2} \\
\text { Australia. }\end{array}$ & McMurray, 2004 \\
\hline $\mathrm{V}=0.145 \mathrm{~A}^{1.314}$ & 10 & $\begin{array}{l}152 \text { ponds of } 0.4-420 \mathrm{ML} \text { measured; } \\
\text { Australia. }\end{array}$ & Lowe et al., 2005 \\
\hline $\begin{array}{l}V=0.002 A^{1.0713} \\
V=2 \times 10^{-7} A^{1.92}\end{array}$ & $\begin{array}{l}11 \mathrm{a} \\
11 \mathrm{~b}\end{array}$ & $\begin{array}{l}\text { Ponds in gullies; >10 ML. } \\
\text { Ponds on flat land; >10 ML; dam } \\
\text { inventory database, New Zealand. }\end{array}$ & $\begin{array}{l}\text { Eden, } 2006 \\
\text { (unpublished) }\end{array}$ \\
\hline
\end{tabular}




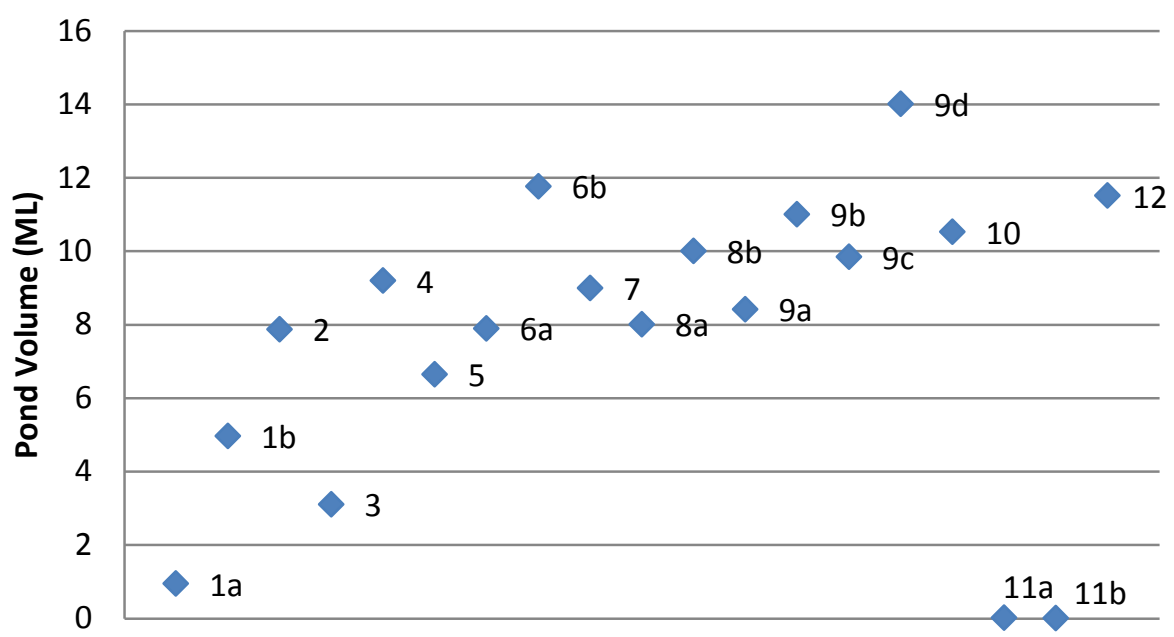

Figure 5.4: Derived pond volumes for a pond surface area of $5000 \mathrm{~m}^{2}$ using derived equations from previous studies. Equations are labelled as in Table 5.1, with the derived area-volume relationship for the current study labelled \#12.

An area-volume equation for the study was derived based on consented dams in the Hawke's Bay region. While most farm dams do not require resource consent for construction, consents are required when water is to be withdrawn from the pond for irrigation, or in cases when allowable size limits and contributing area constraints are surpassed. In these cases, information including the location of the proposed reservoir, height of the dam, upstream catchment area, and reservoir volume is submitted with the resource consent application. It should be noted that these values are pre-construction estimates and do not necessarily represent final dam values. From the collected information in the Hawke's Bay Regional Council dam consent database, 48 dams built for 'irrigation' or 'stock water' use were located on aerial photos and manually digitised, with pond areas automatically measured using GIS tools. From the initial 48 dams, pond area and proposed volume data for 46 ponds were used in the derivation of the areavolume equation. Two ponds were removed from the analysis as their estimated pre-construction volumes were deemed too large in comparison to their postconstruction pond area. The 46 ponds used to derive this relationship had an average volume of $47 \mathrm{ML}$ (range 1.6 to $500 \mathrm{ML}$ ), an average dam height of $5.88 \mathrm{~m}$, and an average surface area of $20,238 \mathrm{~m}^{2}$. 
The derived area-volume relationship $\left(\mathrm{R}^{2}=0.86\right)$ is:

$$
\mathrm{V}=2.321 \mathrm{~A}-101
$$

where $\mathrm{V}=$ volume of pond $\left(\mathrm{m}^{3}\right)$ and $\mathrm{A}=$ surface area of pond at the full storage level $\left(\mathrm{m}^{2}\right)$. A secondary analysis was done on 24 ponds $\leq 20 \mathrm{ML}$ in volume, as these were considered to be more representative of the small farm ponds that are the focus of this study. However, the $\mathrm{R}^{2}$ found in this case was only 0.23 so it was not applied further.

One problem with the application of the derived regional equation occurs in instances when pond areas are less than $50 \mathrm{~m}^{2}$, leading to volumes $<0 \mathrm{~m}^{3}$. As the intercept value (101) is quite small in comparison to pond sizes, it was removed from the equation giving the final area-volume equation:

$$
\mathrm{V}=2.321 \mathrm{~A} \text {. }
$$

Although the relationship was based on pond volume estimates (and not measured volumes), it was determined that local information (even if estimated) would be most applicable for further analysis, particularly as the derived relationship is on the same order of magnitude as those derived elsewhere (as shown in Figure 5.4).

\subsubsection{Description of Farm Dams in Catchment}

Descriptive information on farm dams within both study catchments is based on available regional information, pond digitisation, and values generated from the DEM (Section 5.3.6). These data allow an overview of the characteristics of farm dams in each catchment to be made. Table 5.2 summarises current farm pond characteristics for both the Upper Tukipo and Upper Tukituki catchments. At the present time, farm ponds in both catchments are numerous but small in size, with the vast majority being $\leq 5 \mathrm{ML}$ in volume. There are slightly more ponds per unit area in the Upper Tukipo catchment, which may reflect the greater stock use in the area, as well as the rolling topography which makes the building of storages 
Table 5.2: Farm pond characteristics derived from catchment digitising for the Upper Tukipo and Upper Tukituki catchments.

\begin{tabular}{|c|c|c|}
\hline & Upper Tukipo Catchment & Upper Tukituki Catchment \\
\hline Catchment area & $85 \mathrm{~km}^{2}$ & $740 \mathrm{~km}^{2}$ \\
\hline Total ponds in catchment & 453 & 2117 \\
\hline $\begin{array}{l}\text { Number of onstream } \\
\text { ponds }\end{array}$ & $215(47.5 \%$ of total $)$ & $1165(55 \%$ of total $)$ \\
\hline $\begin{array}{l}\text { Stock ponds }(\leq 5 \mathrm{ML}) \\
\text { Irrigation ponds }(>5 \mathrm{ML})\end{array}$ & $\begin{array}{l}435(96 \% \text { of total }) \\
19(4 \% \text { of total })\end{array}$ & $\begin{array}{l}1962(93 \% \text { of total }) \\
156(7 \% \text { of total })\end{array}$ \\
\hline Density of ponds & $\begin{array}{l}5.3 \text { ponds } / \mathrm{km}^{2} \\
2.5 \text { onstream ponds } / \mathrm{km}^{2}\end{array}$ & $\begin{array}{l}2.9 \text { ponds } / \mathrm{km}^{2} \\
1.6 \text { onstream ponds } / \mathrm{km}^{2}\end{array}$ \\
\hline Total area of all ponds & $0.29 \mathrm{~km}^{2}$ & $2.1 \mathrm{~km}^{2}$ \\
\hline $\begin{array}{l}\text { Ratio of total pond area to } \\
\text { total catchment area }\end{array}$ & $0.0034(0.34 \%)$ & $0.0028(0.28 \%)$ \\
\hline Total volume of all ponds & $680 \mathrm{ML}$ & $4828 \mathrm{ML}$ \\
\hline $\begin{array}{l}\text { Ratio of total pond volume } \\
\text { to total catchment area }\end{array}$ & $\begin{array}{l}8.0 \mathrm{ML} / \mathrm{km}^{2} \\
4.5 \mathrm{ML} / \mathrm{km}^{2} \text { (onstream } \\
\text { ponds) }\end{array}$ & $\begin{array}{l}6.5 \mathrm{ML} / \mathrm{km}^{2} \\
3.9 \mathrm{ML} / \mathrm{km}^{2} \text { (onstream } \\
\text { ponds) }\end{array}$ \\
\hline $\begin{array}{l}\text { Ratio of total pond storage } \\
\text { to mean annual runoff }\end{array}$ & $\begin{array}{l}680 \mathrm{ML} \text { to } 48,377 \mathrm{ML}= \\
1.4 \%\end{array}$ & $\begin{array}{l}4828 \mathrm{ML} \text { to } 4,773,756 \mathrm{ML}= \\
0.1 \%\end{array}$ \\
\hline $\begin{array}{l}\text { Ratio of total pond storage } \\
\text { to mean annual ppt }\end{array}$ & $\begin{array}{l}680 \mathrm{ML} \text { to } 121,380 \mathrm{ML}= \\
0.56 \%\end{array}$ & $\begin{array}{l}4828 \mathrm{ML} \text { to } 628,260 \mathrm{ML}= \\
0.77 \%\end{array}$ \\
\hline
\end{tabular}

more viable. 'Onstream' ponds refer to dams which interrupt streamflow on a drainage line as identified using KiwiImage satellite data.

\subsubsection{Demand and takes from ponds}

In both TEDI and Source Catchments, monthly water takes from ponds are input by the user. Water takes for stock use in the Hawke's Bay region are nonconsented, so actual volumes of water use are not known. In cases where consents are granted (e.g. takes from ponds for irrigation), actual takes are not monitored, so actual volumes can still not be derived. Therefore, this model input must be estimated. 
As a first step, the division between ponds used for stock water and those for irrigation must be set. Gutteridge Haskins \& Davey (1987) surveyed more than 50 farmers in Victoria, Australia and found that $98 \%$ of all domestic and stock water ponds were of volumes $<5 \mathrm{ML}$. Lowe et al. (2005) surveyed a further 130 farmers in the same region and found that $75 \%$ of ponds $<5 \mathrm{ML}$ were used for domestic or stock water and $75 \%$ of ponds $>6 \mathrm{ML}$ were used for irrigation purposes. As a result of these studies, the $5 \mathrm{ML}$ volume is used as a default to mark the separation between stock pond use and irrigation pond use in both the TEDI and Source Catchments models. Because of the lack of local information on farm pond sizes and use, this level will be used in the present study as well.

Lowe et al. (2005) further used their survey of farmers to estimate the proportion of total pond storage water extracted on an annual basis. They found that average yearly demand varied between 0.4 and 0.86 of total pond volume for domestic and stock water use, and between 0.73 and 0.99 for irrigation use, although total demand factors for all uses ranged from 0.1 to 4.0. The TEDI manual suggests that 2.0 is the most common demand factor (SKM, 2002). For the present study, an annual water demand of 1.0 will be used.

In summary, input assumptions based on these studies and knowledge of the present catchments are:

- division between ponds used for stock and those used for irrigation is set at $5 \mathrm{ML}$ (stock ponds $\leq 5 \mathrm{ML}$, irrigation ponds $>5 \mathrm{ML}$ )

- annual water demand is 1.0 for both stock ponds and irrigation ponds

- water is taken evenly throughout the year from stock ponds

- proportional water takes from irrigation ponds will be 0.1 for December and April (the beginning and end of the irrigation season), 0.2 for January, and 0.3 for February and March. All other months will have no irrigation takes as these are times of higher rainfall and lower irrigation need.

- it is assumed that no major changes in climate or land use have occurred over the period of study (1999-2009), which negates the issue of using 
data from a prior regime to predict current or future impacts (Lee et al., 2007).

\subsubsection{DEM derivation and resolution}

For input into the spatially discrete Source Catchments model, a DEM for each study catchment is needed. A national DEM for New Zealand, derived in 2002 from topographic $20 \mathrm{~m}$ contour data and spot heights, is freely available. This DEM has a resolution of $25 \mathrm{~m}$ and a root mean square accuracy of 5 to $8 \mathrm{~m}$ (horizontal) and $6 \mathrm{~m}$ (vertical) (Barringer et al., 2002). A further refinement of this data was made by GNS Science using additional contour data and spot heights, allowing a $10 \mathrm{~m}$ DEM to be produced. Although some LiDAR data is available for the study catchments, the data does not cover the entire area of interest and the accuracy gained from its higher resolution was not deemed necessary for the present study. As well, the higher resolution DEM derived from LiDAR data would increase the processing time of all model runs significantly. Therefore, the $10 \mathrm{~m}$ DEM was chosen as the best option for use in the Source Catchments model.

\subsubsection{Calibration of AWBM rainfall-runoff model}

As previously discussed, for use within Source Catchments, the Australian Water Balance Model (AWBM) was chosen as the most representative rainfall-runoff model for the characteristics of the catchments under study. The model was first calibrated using measured rainfall, evapotranspiration, and runoff from the catchment at a daily time step. A total of nine parameters are calibrated, representing three surface storage capacities (A1, A2, A3), three partial areas for those same storages (C1, C2, C3), a baseflow index (BFI), and recession constants for baseflow and surface flow (Kbase, $\mathrm{K}_{\text {surf }}$ ). The model is most sensitive to the latter three parameters (BFI, Kbase, $\mathrm{K}_{\text {surf }}$ ) (eWater CRC, 2010), so these were the focus of the calibration runs. In earlier versions of the model, partial areas were manually calculated using a graphical method based on rainfall and runoff events at times 
of low antecedent wetness. This procedure has been superseded by a multiple linear regression technique, based on monthly values of rainfall and runoff, and calculated automatically within the AWBM calibration step (Boughton, 2004). The BFI is the ratio of baseflow to total flow in the stream, while the recession constants (Kase, $\mathrm{K}_{\text {surf }}$ ) are used to calculate the rate of depletion from storages in the manner:

$$
(1-K x) S x
$$

where $x=$ either baseflow or surface flow and $S=$ storage under consideration. All values are dimensionless apart from the partial areas $(\mathrm{C} 1, \mathrm{C} 2, \mathrm{C} 3)$ which are measured in millimetres. The parameterisation of both catchments was completed (as described in more detail below) using the AWBM calibration programme within the Rainfall-Runoff Library (CRC for Catchment Hydrology, 2004).

Available data were divided into a calibration period (1999-2006) and a verification period (2007-2009), with a 6-month warm-up at the beginning of both periods. Within the Rainfall-Runoff Library, calibration runs can be performed automatically or manually. In the first instance, all calibrations were automatically run using the SCE-UA optimisation method (Duan et al., 1992), with root mean square error (RMSE) minimised as the primary objective. After the parameters were automatically calculated, they were checked for consistency with known catchment characteristics and then manually manipulated to achieve a closer visual fit between the predicted and observed runoff time series.

One issue that arose initially with the automatic calibration was runoff seasonality, with flow consistently under predicted during the higher flows of winter and over predicted during the lower flows of summer (Tukipo River calibration run shown in Figure 5.5 as an example). To test the effect of seasonality on parameter values, separate calibrations were run on a drier period (2001-2003) and a wetter period (2005-2007) in the Upper Tukipo catchment. 


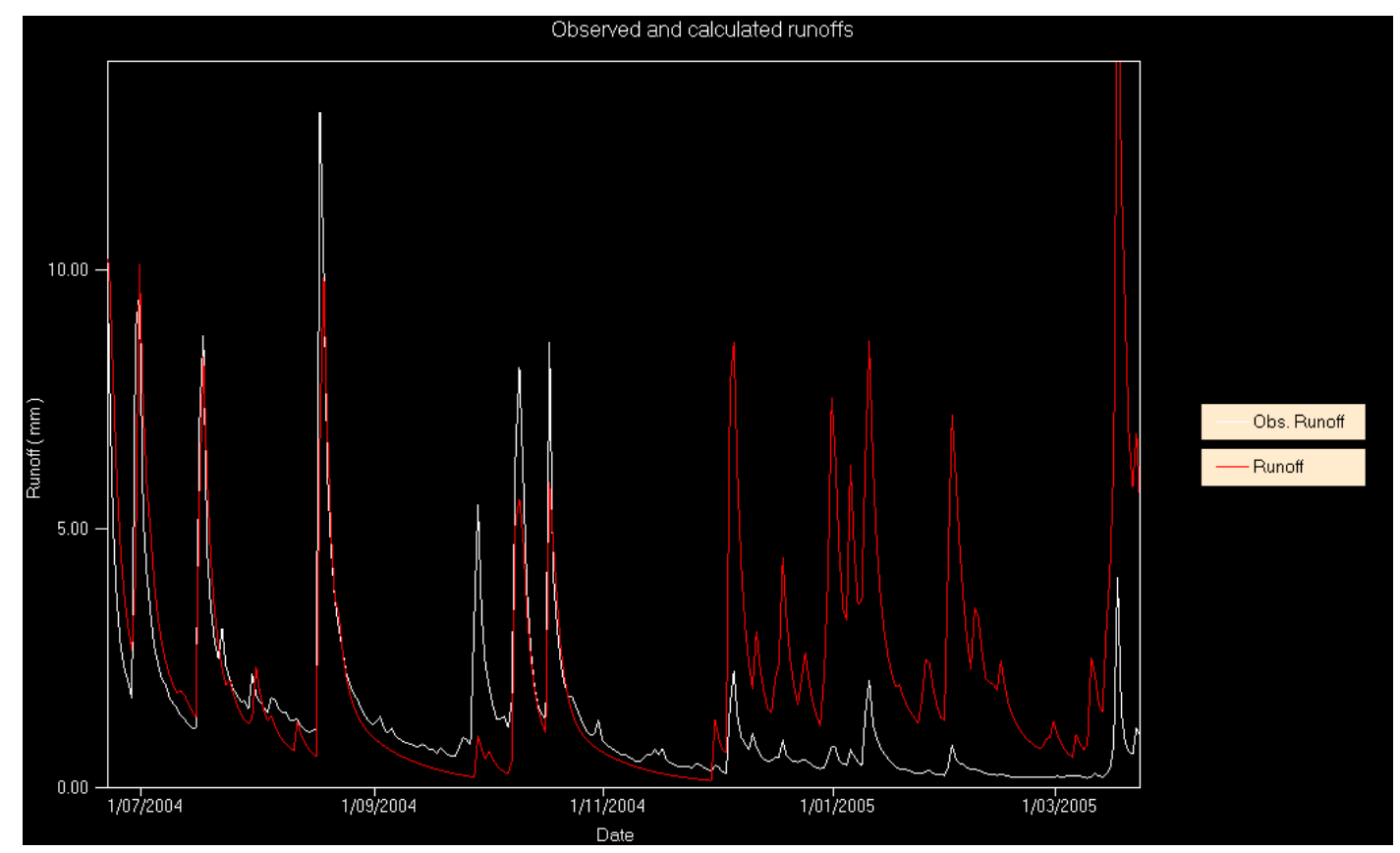

Figure 5.5: Hydrographs of observed and AWBM modelled runoff for the Tukipo River, showing under prediction of winter flows (left side of figure) and over prediction of summer flows (right side of figure). Modelled runoff is in red, observed runoff is in white.

Dry and wet periods were chosen based on the greatest deviation from average annual precipitation. The parameters automatically derived from the split dry and wet periods are summarised in Table 5.3 with calibrations shown in Figure 5.6. The most significant difference found was between the recession constants for baseflow (Kase) and surface flow (K $\left.\mathrm{K}_{\text {surf }}\right)$, revealing the difficulty in representing the rate of storage depletion with a single value for both dry and wet periods.

The seasonality of flow may be explained by known gaining reaches within the catchments under study (HBRC, 2003; Baalousha, 2009). Surface water groundwater interactions show a complex relationship throughout the catchment, with losing streams primarily found in the Upper Tukituki and Waipawa basins, and gaining reaches in their lower basins (Baalousha, 2009). Gaining reaches would likely have additional lateral flow inputs during wetter periods when the catchment is hydrologically connected to adjacent catchments. Under drier conditions, these connections would not exist, and the streams may have losing reaches which would contribute to groundwater recharge. There may 
Table 5.3: Seasonal parameters as derived separately under dry (2001-2003) and wet (2005-2007) conditions for the Upper Tukipo catchment. Values are dimensionless unless otherwise specified.

\begin{tabular}{|c|c|c|}
\hline Parameter & Dry Period & Wet Period \\
\hline A1 & 0.32 & 0.20 \\
\hline A2 & 0.46 & 0.57 \\
\hline A3 & 0.22 & 0.23 \\
\hline BFI & 0.62 & 0.59 \\
\hline C1 & $40.2 \mathrm{~mm}$ & $12.4 \mathrm{~mm}$ \\
\hline C2 & $283.7 \mathrm{~mm}$ & $332.6 \mathrm{~mm}$ \\
\hline C3 & $507.8 \mathrm{~mm}$ & $1485.1 \mathrm{~mm}$ \\
\hline Kbase & 0.966 & 0.329 \\
\hline K$_{\text {surf }}$ & 0.444 & 0.840 \\
\hline
\end{tabular}
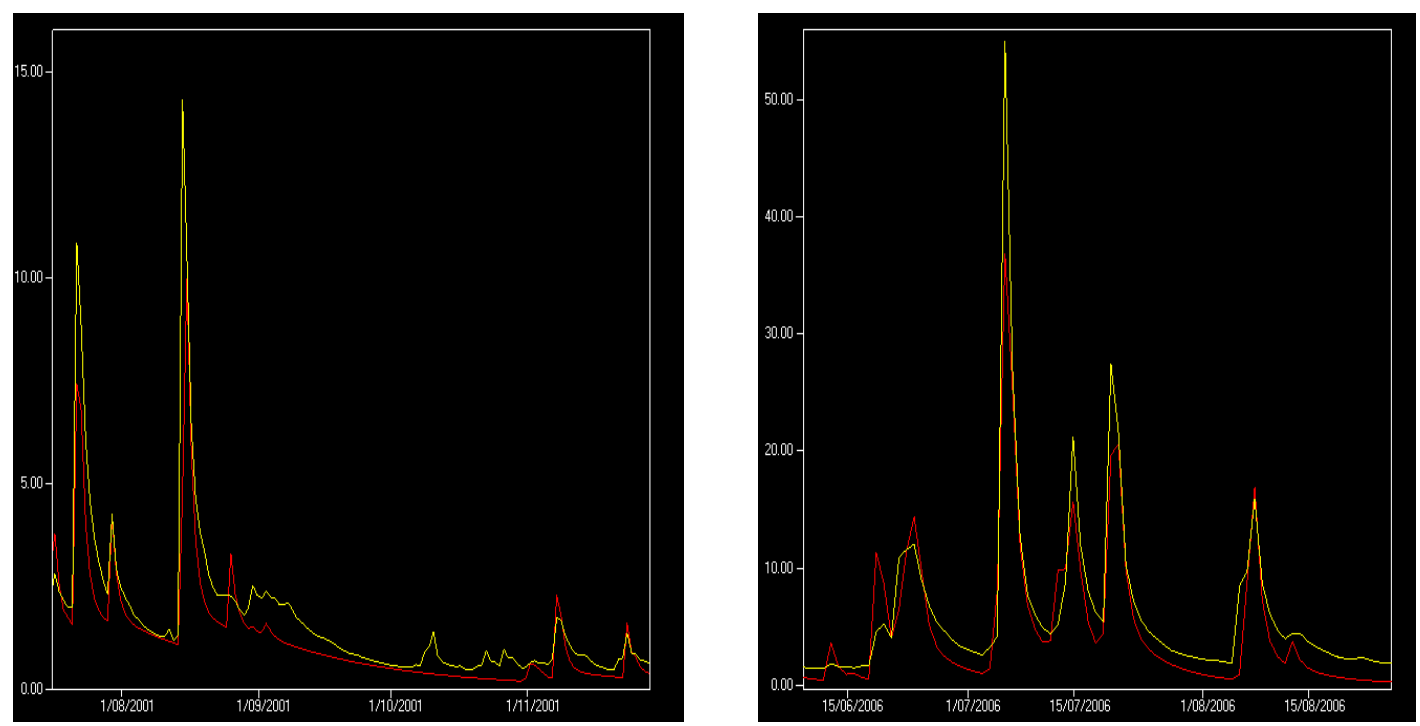

Figure 5.6: Hydrographs of calibration runs for A. dry years (Aug-Dec, 2001 shown) and B. wet years (June-Sep, 2006 shown), revealing a better calibration fit when seasonality effects are removed. Modelled runoff is in red, observed streamflow in yellow.

also be some variability in the volume of subsurface water stored on an annual basis and its spatial distribution across catchment boundaries. Baalousha (2010) suggests that increased groundwater abstraction since 1990 has affected the gaining-losing relationships, and river gains from both the groundwater aquifer and from springs have been decreasing over this period. The Upper Tukipo basin 
has not been extensively studied, but it is reasonable to assume that the relationships found elsewhere in the Ruataniwha basin will also exist in the Tukipo catchment.

The fact that the AWBM model is unable to accurately predict these seasonal changes suggests that the model (with its three storages) may be too simplistic to represent the heterogeneous nature of the catchment. This inaccuracy points to the need for the development of a model which allows for seasonally varying parameters. Further modelled output from Source Catchments is considered with these timing inaccuracies in mind.

The final derived parameters used for the AWBM model are summarised in Table 5.4, with examples of final calibration runs for the Upper Tukipo and Upper Tukituki shown in Figure 5.7. The final parameter sets represent a compromise between seasonal extremes, and are meant to provide the best overall fit for the study catchments. The final parameters for both catchments are fairly similar, although the Upper Tukipo has a lower baseflow index value as well as a lower baseflow recession value, which may reflect the higher permeability of the

Table 5.4: Final parameters for AWBM model as derived for the Upper Tukipo and Upper Tukituki catchments. Values are dimensionless unless otherwise specified.

\begin{tabular}{|c|c|c|}
\hline Parameter & Upper Tukipo & Upper Tukituki \\
\hline $\mathrm{A} 1$ & 0.24 & 0.30 \\
\hline $\mathrm{A} 2$ & 0.38 & 0.30 \\
\hline $\mathrm{A} 3$ & 0.38 & 0.40 \\
\hline $\mathrm{BFI}$ & 0.43 & 0.54 \\
\hline $\mathrm{C} 1$ & $34 \mathrm{~mm}$ & $29 \mathrm{~mm}$ \\
\hline $\mathrm{C} 2$ & $364 \mathrm{~mm}$ & $311 \mathrm{~mm}$ \\
\hline $\mathrm{C} 3$ & $880 \mathrm{~mm}$ & $1443 \mathrm{~mm}$ \\
\hline Kbase & 0.450 & 0.701 \\
\hline Ksurf & 0.945 & 0.973 \\
\hline
\end{tabular}



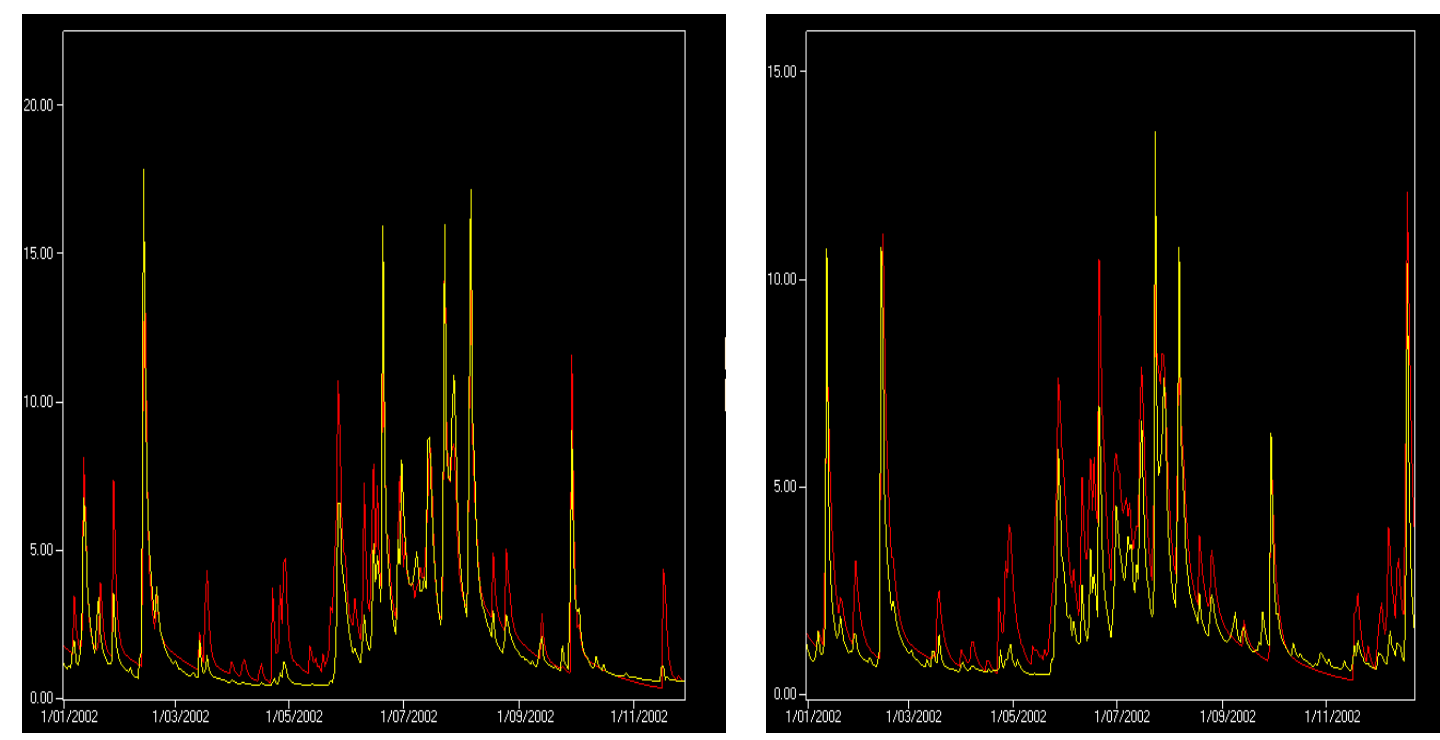

Figure 5.7: Hydrographs of calibration runs (for 2002) based on final parameter values for the Upper Tukipo catchment (left) and Upper Tukituki catchment (right). Modelled runoff is in red, observed runoff is in yellow.

underlying gravels in the Tukipo catchment, leading to quicker flow through the underground storages. There may also be a component of catchment averaging occurring over the larger Tukituki basin, bringing the baseflow and surface flow recession constants closer in value.

\subsection{Scenario Runs}

\subsubsection{Model runs for TEDI}

Derived input parameters for the TEDI model, as discussed above, are summarised in Table 5.5. Wherever possible, measured or estimated values specific to the study catchments are used for model input. In running the TEDI model, two scenarios were chosen; one representing current conditions (i.e. actual farm pond numbers and size distributions), and one representing a future scenario of agricultural intensification where larger ponds are being built for irrigation purposes. In the first scenario (referred to as 'Stock'), the majority of ponds are assigned to stock use (as $>90 \%$ of the ponds in both catchments are currently $\leq 5 \mathrm{ML}$ volume). In the second case (referred to as 'Irrigation'), the total storage volume is assumed to be equal to current storage volumes, but a greater 
number of ponds are assigned to irrigation use (i.e. $>5 \mathrm{ML}$ volume) with

associated higher water takes as expected for irrigation purposes.

Table 5.5: Input parameters and derivation of same, as used in the TEDI model.

\begin{tabular}{|c|c|}
\hline Input parameter & Input specifics and derivation of values for study catchments \\
\hline $\begin{array}{l}\text { Flow } \\
\text { (ML/month) }\end{array}$ & $\begin{array}{l}\text { Monthly time step, January } 1999 \text { to September 2009, using } \\
\text { measured monthly flow volumes from HBRC data: Tukipo River at } \\
\text { SH50 and the Tukituki River at Waipukurau. }\end{array}$ \\
\hline Catchment area & $\begin{array}{l}\text { Measured in ArcGIS, } 85 \mathrm{~km}^{2} \text { for Upper Tukipo, } 740 \mathrm{~km}^{2} \text { for Upper } \\
\text { Tukituki. }\end{array}$ \\
\hline $\begin{array}{l}\text { Catchment area } \\
\text { of } 5 \mathrm{ML} \text { and } \\
100 \mathrm{ML} \text { ponds }\end{array}$ & $\begin{array}{l}\text { Manually measured upstream catchment areas for } 60 \text { onstream } \\
\text { ponds of various sizes using ArcGIS. A linear relationship was } \\
\text { derived between pond volume and upstream catchment area }(\mathrm{y}= \\
\left.0.0053 \mathrm{x}+0.0829 ; \mathrm{R}^{2}=0.59\right) \text { and area calculated for } 5 \mathrm{ML} \text { and } 100 \\
\text { ML ponds using this relationship }\left(0.1 \mathrm{~km}^{2} \text { and } 0.6 \mathrm{~km}^{2} \text { respectively). }\right.\end{array}$ \\
\hline $\begin{array}{l}\text { Total volume of } \\
\text { ponds }\end{array}$ & $\begin{array}{l}\text { Ponds in both catchments were manually digitised, with areas used } \\
\text { as input for the study-derived area-volume relationship (V=2.321A; } \\
\text { Section 5.3.3). Total derived volumes are: Upper Tukipo = } 680 \mathrm{ML} \text {, } \\
\text { Upper Tukituki = } 4828 \mathrm{ML} \text {. Future pond volumes were set at } \\
\text { double the current volumes (i.e. } 1360 \mathrm{ML} \text { and } 9656 \mathrm{ML} \text { ). }\end{array}$ \\
\hline Demand & $\begin{array}{l}\text { The threshold between ponds used for stock and those for } \\
\text { irrigation was set at } 5 \mathrm{ML} \text { (best estimate based on Australian } \\
\text { studies; Section 5.3.5). Stock water is extracted evenly throughout } \\
\text { year; irrigation water is extracted during dry months only } \\
\text { (December-April) (see Section } 5.3 .5 \text { for values). }\end{array}$ \\
\hline Demand factor & $\begin{array}{l}\text { Indicates the total volume of water extracted from each dam } \\
\text { annually. Set at } 1.0 \text { for both stock and irrigation dams for both } \\
\text { catchments under all scenarios (see Section } 5.3 .5 \text { for further } \\
\text { details). }\end{array}$ \\
\hline $\begin{array}{l}\text { Distribution of } \\
\text { farm dam } \\
\text { storage }\end{array}$ & $\begin{array}{l}\text { Derived storage volumes for each pond were grouped and entered } \\
\text { as a proportion of the total number of ponds. These were used in } \\
\text { the 'Stock' scenario; proportions for the 'Irrigation' scenario were } \\
\text { adjusted to account for a greater number of ponds over } 5 \mathrm{ML} \text { in } \\
\text { volume. }\end{array}$ \\
\hline $\begin{array}{l}\text { Bypass } \\
\text { structures }\end{array}$ & $\begin{array}{l}\text { The size of dams for which bypasses exist was set at } 0 \text { for all runs as } \\
\text { no bypass facilities exist in either catchment. Bypass structures } \\
\text { were included in one run on the Upper Tukipo catchment, with } \\
\text { results in Section 5.5.3. }\end{array}$ \\
\hline Climate & $\begin{array}{l}\text { Monthly time series of rainfall (mm) and point potential } \\
\text { evaporation (mm) from Jan } 1999 \text { to Sept } 2009 \text { derived for both } \\
\text { catchments (derivation described in Section 5.3.1). }\end{array}$ \\
\hline
\end{tabular}


For each scenario run, catchment runoff volumes are calculated for current pond storage volumes, future pond volumes, and 'natural' conditions representing no farm pond storage in the catchment. A doubling of current catchment storage volumes was chosen to represent future conditions. Model results are summarised below by comparing the 'natural' streamflow volumes (no farm pond storage in catchment) to streamflow output for 'Stock' (for current stock use), 'Stock x 2' (for future stock use), 'Irrigation' (for current irrigation use), and 'Irrigation x 2' (for future irrigation use).

Following these first runs, a second run of the same scenarios was conducted on both catchments using altered precipitation values as suggested by regional climate change estimates (MFE, 2008). The A1B climate change scenario to 2040 predicts an increase in precipitation volume for summer $(+4 \%)$ and autumn $(+5 \%)$ and a decrease in precipitation volume for winter $(-13 \%)$ and spring $(-7 \%)$, with a net annual change in precipitation of $-3 \%$. These scenarios are referred to as 'Climate Change Stock' and 'Climate Change Irrigation' with the same doubling of storage volume for the future scenario runs ('Climate Change Stock $\mathrm{x}$ 2' and 'Climate Change Irrigation x 2').

\subsubsection{Model runs for Source Catchments}

Within Source Catchments, the effect of farm dams on streamflow is simulated using basic TEDI concepts, albeit at a finer temporal and spatial scale. Source Catchments is run on a daily time step and farm dam densities within subcatchments are represented in a semi-lumped manner. Farm dam densities $\left(\mathrm{ML} / \mathrm{km}^{2}\right)$ are derived from information provided through the pond digitisation process. Apart from these values and the use of a daily time step for climate data (precipitation, AET), the rest of the farm dam inputs remain the same as previously described for the TEDI model (as outlined in Table 5.5).

Similar scenarios to those run in the TEDI analysis were run in the Source Catchments model, namely, 'Stock', 'Stock x 2', and 'Climate Change Stock'. A 
scenario representing flow within the catchment with no storage dams ("No Dams') was also run for comparison purposes, as the model does not automatically create a 'natural' flow regime as in the TEDI model. The full set of TEDI scenarios was not re-run within Source Catchments because TEDI results showed a similarity in predicted output in some of the initial scenarios (further discussed below). All Source Catchments scenarios were run on a daily time step from Jan 1, 1999 to Dec 31, 2009.

\subsection{Results of scenario runs}

\subsubsection{Stock pond and irrigation scenarios}

The TEDI model uses observed streamflow data (which is output as 'current' flow) to back-calculate the 'natural' flow regime which would exist if no farm dams were present in the catchment. The same 'natural' flow is calculated in Source Catchments by running the AWBM rainfall-runoff component model with no dams present ('No Dams' scenario). Total monthly streamflow predictions from both models are compared in Figure 5.8, revealing that streamflow is largely over predicted by Source Catchments. This over prediction (discussed in Section 5.3.7) presents a problem when comparing flow volumes between the models, and also when interpreting results of Source Catchments scenarios. The largest discrepancy between observed and modelled flow in Source Catchments is during large winter storm events when observed flow volumes are under predicted by the model. This may not be critical for the farm dam assessment, as this is a time when the cumulative impact of farm dams on streamflow is at its lowest. The over prediction of summer low flows, on the other hand, will affect the volume of water routed through the farm ponds, and will likely result in a lower farm dam impact on streamflow than is expected. 


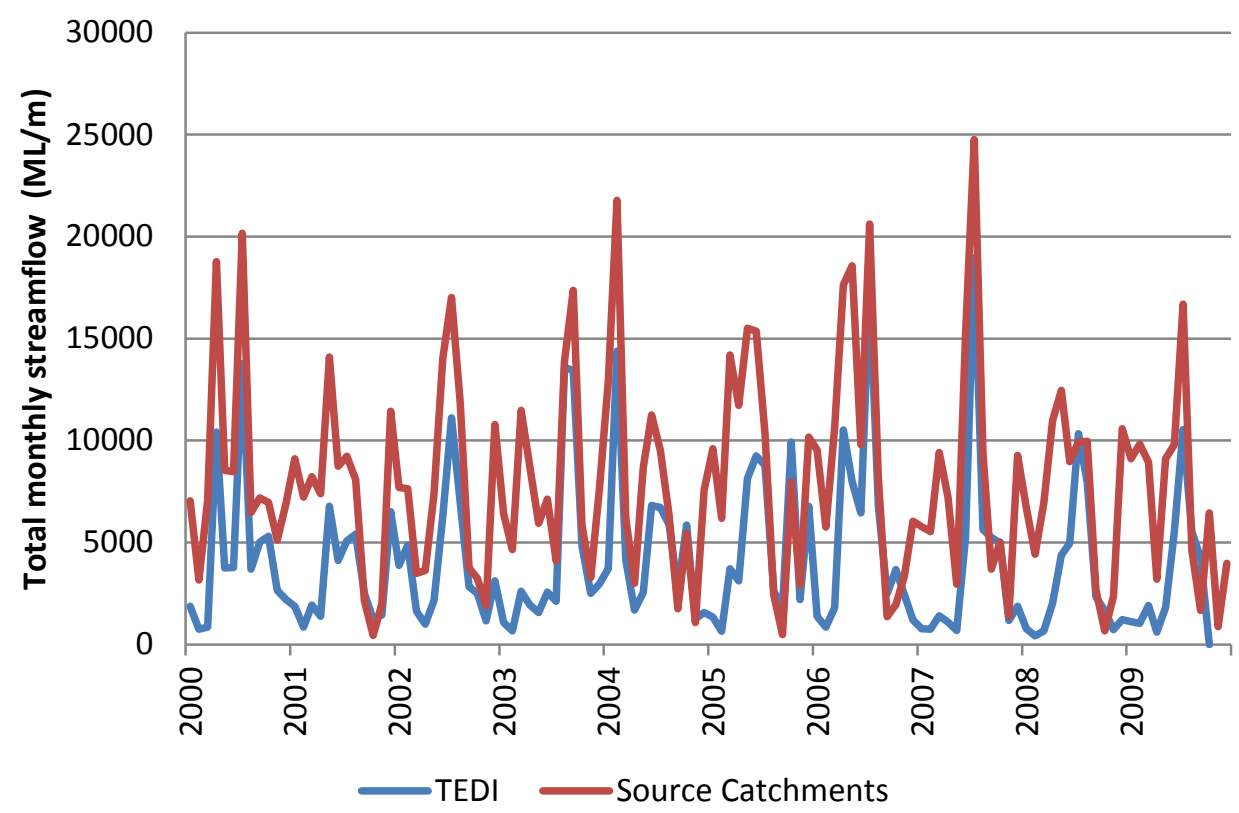

Figure 5.8: Comparison of total monthly streamflow (ML) at the Upper Tukipo catchment outlet as predicted by the TEDI and Source Catchments (SC) models for a scenario of no dams within the catchment. Annual values are placed at the January 1 mark for each year.

\section{TEDI results}

Table 5.6 summarises results for the 'Stock' and 'Stock $\mathrm{x}$ 2' scenarios in both catchments for the period 1999-2009. All changes to streamflow are compared to 'natural' conditions of no farm pond storage within the catchment, as calculated by the model, and negative values represent a decrease in streamflow volumes from these natural conditions.

TEDI model output from the stock and irrigation runs suggest that the current level of farm dam development in the Upper Tukipo catchment is already affecting catchment streamflow volumes. Annual streamflow volumes have decreased by an average of $528 \mathrm{ML}$ ('Stock') and $547 \mathrm{ML}$ ('Irrigation'). When farm dam volumes are doubled under future projections, these annual losses also double to $1048 \mathrm{ML}$ ('Stock x 2') and $1094 \mathrm{ML}$ ('Irrigation x 2'). The average decrease in total annual runoff volume on the Upper Tukipo is between 1.1\% ('Stock') and 2.3\% ('Irrigation x 2'). 
Table 5.6: TEDI modelled change in streamflow as a result of farm ponds for 'Stock' and 'Stock x 2' scenarios in the Upper Tukipo and Upper Tukituki catchments. Negative values represent a decrease in streamflow volumes from natural (no dam) conditions.

\begin{tabular}{|l|l|l|}
\hline Upper Tukipo & Stock & Stock x 2 \\
\hline Average monthly & $-2.8 \%$ & $-5.6 \%$ \\
streamflow change & $(-44 \mathrm{ML} / \mathrm{m})$ & $(-87 \mathrm{ML} / \mathrm{m})$ \\
\hline Range of monthly & 0 to $-13 \%$ & 0 to $-26 \%$ \\
streamflow change & $(0$ to $-102 \mathrm{ML} / \mathrm{m})$ & $(0$ to $-203 \mathrm{ML} / \mathrm{m})$ \\
\hline Average annual & $-1.1 \%$ & $-2.2 \%$ \\
streamflow change & $(-528 \mathrm{ML} / \mathrm{y})$ & $(-1049 \mathrm{ML} / \mathrm{y})$ \\
\hline
\end{tabular}

\begin{tabular}{|l|l|l|}
\hline Upper Tukituki & Stock & Stock x 2 \\
\hline Average monthly & $-1.9 \%$ & $-3.9 \%$ \\
streamflow change & $(-334 \mathrm{ML} / \mathrm{m})$ & $(-680 \mathrm{ML} / \mathrm{m})$ \\
\hline Range of monthly & 0 to $-9 \%$ & 0 to $-18 \%$ \\
streamflow change & $(0$ to $-859 \mathrm{ML} / \mathrm{m})$ & $(0$ to $-1717 \mathrm{ML} / \mathrm{m})$ \\
\hline Average annual & $-0.9 \%$ & $-1.8 \%$ \\
streamflow change & $(-4000 \mathrm{ML} / \mathrm{y})$ & $(-8000 \mathrm{ML} / \mathrm{y})$ \\
\hline
\end{tabular}

Similar patterns are found for the Upper Tukituki catchment, with predicted average annual losses of 4000 ML ('Stock') and 4083 ML ('Irrigation'), and a doubling of losses when catchment storage volumes are doubled under future projections. The average decrease in total annual runoff volume on the Upper Tukituki is between $0.9 \%$ ('Stock') and 1.8\% ('Irrigation x 2'). The higher proportional impact of farm pond storages on runoff volumes in the Upper Tukipo catchment, as compared to the Upper Tukituki catchment, reflects the higher proportion of the catchment covered by farm ponds $(0.34 \%$ in the Upper Tukipo, as compared to $0.28 \%$ in the Upper Tukituki).

In both catchments there is no significant difference predicted between the stock and irrigation scenarios, although losses are slightly higher under the irrigation scenario due to takes from the ponds during the dry summer months. The slight difference in total loss between the two scenarios suggests that the model is more sensitive to the total volume of farm pond storage rather than to the size distribution of individual ponds. This will have some significance to water managers using the model to investigate farm dam size and density scenarios. 
Effects of farm dams on monthly streamflow volume show a similar pattern each year, with little to no effect during the wetter winter months and maximum impacts during the drier summer months. An example of this pattern is shown in Figure 5.9, using departures from 'natural' monthly flow in the Upper Tukipo catchment, 2008. Maximum impacts on streamflow volumes for the 1999-2009 period were found in the driest month on record (Feb, 2008) with a monthly streamflow decrease from 'no dam' conditions of $26 \%$ and $18 \%$ for the Upper Tukipo and Upper Tukituki catchments respectively ('Stock x 2' scenario).

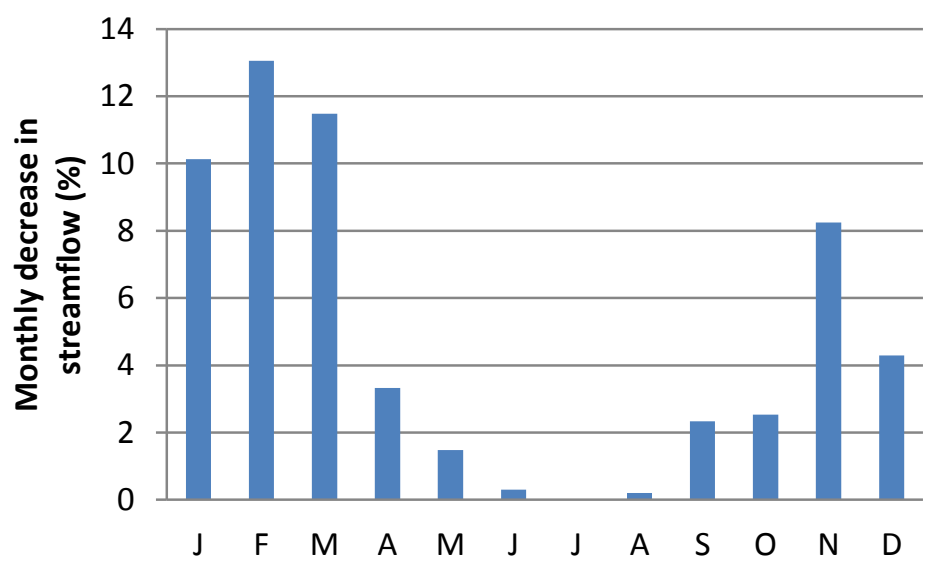

Figure 5.9: Total monthly decrease in streamflow (\%) for the Upper Tukipo catchment, 2008, derived by TEDI, showing the difference between 'natural' flow and current ('Stock') conditions, with a maximum decrease in dry summer months and a minimum impact in wet winter months.

\section{Source Catchments results}

In general, total streamflow losses for Source Catchment scenarios are very similar to those found in TEDI runs (Table 5.7). Results from the 'Stock' and 'Stock x 2' scenarios reveal that farm ponds in both the Upper Tukipo and Upper Tukituki catchments reduce downstream flow volumes by an average of 1 to $3 \%$. For the 'Stock' scenario on the Upper Tukipo catchment this represents an annual streamflow decrease of $531 \mathrm{ML}$, as compared to $528 \mathrm{ML}$ for the same scenario run in TEDI. In the Upper Tukipo catchment, there was no significant difference found in peak flow volumes $\left(\mathrm{Q}_{10}\right)$ between the 'No dams' and 'Stock' scenarios 
(0.4 ML/d difference), but there was a $1.5 \%$ decrease in mean daily baseflow (1.8 ML/d).

Table 5.7: Source Catchments modelled change in daily streamflow as a result of farm ponds for 'Stock' scenarios in the Upper Tukipo catchment. Negative values represent a decrease in streamflow volumes from natural (no dam) conditions, positive values represent an increase.

\begin{tabular}{|l|l|l|}
\hline Upper Tukipo & Stock & Stock x 2 \\
\hline Average daily & $-1.9 \%$ & $-2.8 \%$ \\
streamflow change & $(-1.5 \mathrm{ML} / \mathrm{d})$ & $(-2.0 \mathrm{ML} / \mathrm{d})$ \\
\hline Range of daily & +28.7 to $-24.1 \%$ & +63.1 to $-25.4 \%$ \\
streamflow change & $(+33$ to $-14 \mathrm{ML} / \mathrm{d})$ & $(+67$ to $-24 \mathrm{ML} / \mathrm{d})$ \\
\hline Average annual & $-0.57 \%$ & $-0.79 \%$ \\
streamflow change & $(-531 \mathrm{ML} / \mathrm{y})$ & $(-737 \mathrm{ML} / \mathrm{y})$ \\
\hline
\end{tabular}

\begin{tabular}{|l|l|l|}
\hline Upper Tukituki & Stock & Stock x 2 \\
\hline Average daily & $-0.9 \%$ & $-1.5 \%$ \\
streamflow change & $(-4.9 \mathrm{ML} / \mathrm{d})$ & $(-8.6 \mathrm{ML} / \mathrm{d})$ \\
\hline Range of daily & +8.7 to $-6.6 \%$ & +16.4 to $-9.90 \%$ \\
streamflow change & $(+130$ to $-48 \mathrm{ML} / \mathrm{d})$ & $(+241$ to $-105 \mathrm{ML} / \mathrm{d})$ \\
\hline Average annual & $-0.4 \%$ & $-0.73 \%$ \\
streamflow change & $(-1771 \mathrm{ML} / \mathrm{y})$ & $(-3116 \mathrm{ML} / \mathrm{y})$ \\
\hline
\end{tabular}

As found in the TEDI modelling runs, farm dams in the Upper Tukipo catchment show a greater influence on downstream flow volumes as compared to those of the Upper Tukituki catchment. However, the impacts on streamflow are proportionally lower when farm dam volumes are doubled for the future scenario runs in Source Catchments. In TEDI, the impact on streamflow volumes doubled when farm pond storage volumes were doubled in future scenario runs. This is representative of the model's assumption of a linear relationship between dam volumes and streamflow volumes. The difference in the Source Catchments predictions is related to the differences inherent in the component rainfall-runoff modelling.

Daily streamflow volumes reveal times of net loss and net gain in all farm dam scenario runs as compared to modelled flow with no dams present. As an example, the 'Stock' scenario sometimes shows an increase in daily streamflow as 
compared to the 'No Dams' scenario, suggesting an amelioration of flow because of the dams. In all cases, times of net gain in daily flow are associated with the timing of a large storm event. A similar effect was observed in the paired catchment field study, where the regulated stream had a longer time of rise to peak stormflow volumes and a longer recession period, leading to more total days of flow as compared to the unregulated stream. However, in the Source Catchments modelling runs the gains occur periodically throughout the entire streamflow record, even during the dry summer when it is expected that ponds would be below full levels, thereby creating a disconnection in the streamflow system. Because the AWBM rainfall-runoff component model over predicts periods of low flow, the timing of gains suggest that the farm ponds remain close to full throughout the year, an occurrence that may not always be valid.

In Source Catchments, modelled streamflow output can be derived at any subcatchment outlet. Therefore, one further comparison was made between modelled streamflow at a representative subcatchment and measured streamflow at the regulated field catchment (from the paired catchment field study) for the study period (Aug 1, 2008 to Aug 1, 2009). Although the subcatchments being compared are not in the exact same location, they both have similar catchment areas, farm dam volumes, and mid-catchment locations. Daily streamflow for both subcatchments are shown in Figure 5.10, and reveal that the model does not capture the period of no flow through the summer when ponds were below full levels and disconnected from the downstream system. Modelled flow shows a continuous response to storm events throughout this period, which could be related to the overestimation of low flows by the AWBM rainfall-runoff component model. Another possible influence would be the separate routing of each pond's outflow to the subcatchment outlet, which minimises the cascade effect from multiple dams on the same stream. Discharge is also greatly overestimated by the model at the beginning of the winter flow period, a time 


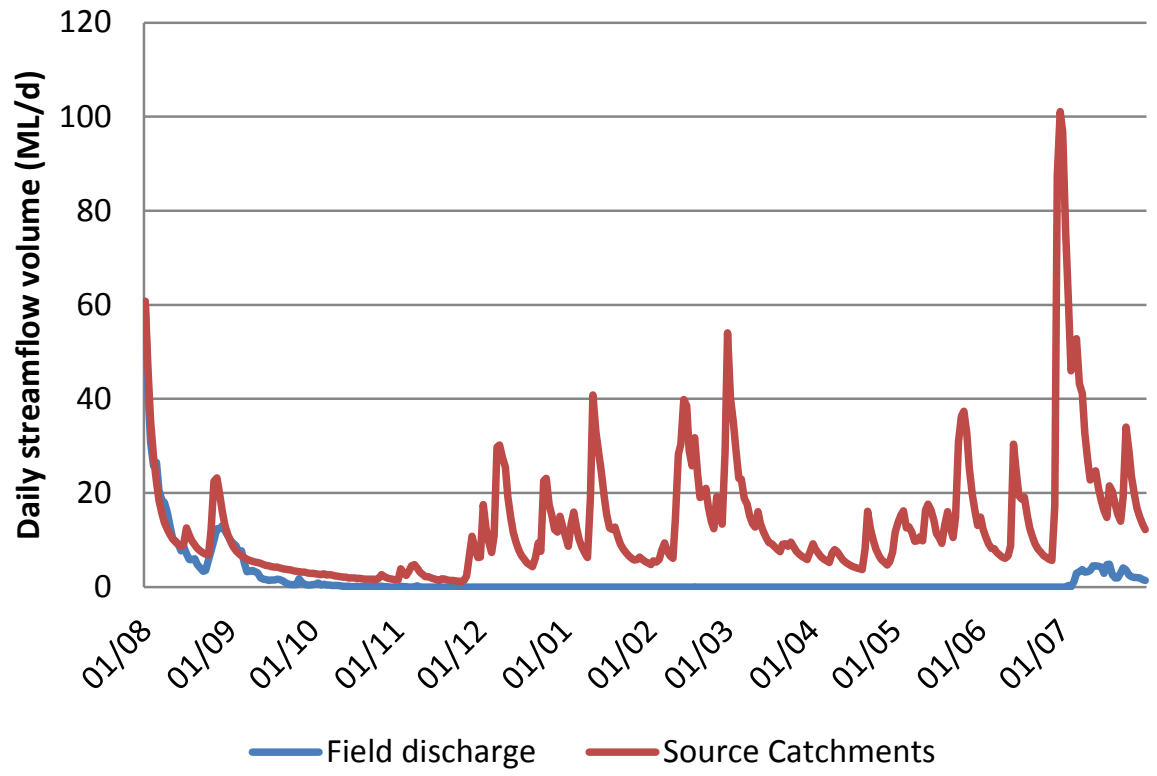

Figure 5.10: Modelled streamflow from a Tukituki subcatchment (labelled 'Source Catchments'), compared to streamflow derived from field observations from the regulated stream in the field study catchment (labelled 'Field discharge'), for the period Aug 1, 2008 to Aug 1, 2009.

when flow in the field catchment was delayed until the ponds filled to capacity, overflowed, and were once again connected to the downstream system.

\subsubsection{Climate change scenarios}

In the Hawke's Bay region, it is predicted that climate change will cause annual precipitation volumes to decrease, but seasonal shifts suggest that drier seasons (summer and autumn) will become wetter, and that wetter seasons (winter and spring) will become drier (MFE, 2008). Predicted changes from the A1B climate change scenario to 2040 were applied to regional precipitation data, and the 'Stock' scenario was re-run for both catchments using both models.

The TEDI predictions reveal that farm dams in both catchments under future climate scenarios have the same magnitude of impact on streamflow volumes as they do at present (Table 5.8; Upper Tukipo comparison shown). This may reflect the imprecision of the monthly time step in capturing the predicted seasonal changes on a storm event basis. Since precipitation volumes in both catchments 
show a high variability overall, it is anticipated that the impact of predicted precipitation change may become more significant in individual years. A model that has a finer time step may reveal a greater impact on streamflow volumes under predicted climate change.

Table 5.8: Comparison of TEDI and Source Catchments predicted streamflow under current and future precipitation volumes for the Upper Tukipo catchment. TEDI values are based on a monthly time-step, Source Catchments values on a daily time-step. Negative values represent a decrease in streamflow volumes from natural (no dam) conditions, positive values represent an increase.

\begin{tabular}{|l|l|l|}
\hline Upper Tukipo & $\begin{array}{l}\text { TEDI } \\
\text { current climate }\end{array}$ & $\begin{array}{l}\text { TEDI } \\
\text { future climate }\end{array}$ \\
\hline Average monthly & $-2.8 \%$ & $-2.8 \%$ \\
streamflow change & $(-44 \mathrm{ML} / \mathrm{m})$ & $(-44 \mathrm{ML} / \mathrm{m})$ \\
\hline Range of streamflow & 0 to $-13 \%$ & 0 to $-13.1 \%$ \\
change & $(0$ to $-102 \mathrm{ML} / \mathrm{m})$ & $(0$ to $-100 \mathrm{ML} / \mathrm{m})$ \\
\hline $\begin{array}{l}\text { Average annual } \\
\text { streamflow change }\end{array}$ & $-1.1 \%$ & $-1.0 \%$ \\
\hline
\end{tabular}

\begin{tabular}{|l|l|l|}
\hline Upper Tukipo & $\begin{array}{l}\text { Source Catchments } \\
\text { current climate }\end{array}$ & $\begin{array}{l}\text { Source Catchments } \\
\text { future climate }\end{array}$ \\
\hline Average daily & $-1.9 \%$ & $-9.3 \%$ \\
streamflow change & $(-1.5 \mathrm{ML} / \mathrm{d})$ & $(-11.8 \mathrm{ML} / \mathrm{d})$ \\
\hline Range of streamflow & +28.7 to $-24.1 \%$ & +70.4 to $-98.5 \%$ \\
change & $(+33$ to $-14 \mathrm{ML} / \mathrm{d})$ & $(+303$ to $-380 \mathrm{ML} / \mathrm{d})$ \\
\hline $\begin{array}{l}\text { Average annual } \\
\text { streamflow change }\end{array}$ & $-0.57 \%$ & $-4.7 \%$ \\
$(-531 \mathrm{ML} / \mathrm{y})$ & $(-4729 \mathrm{ML} / \mathrm{y})$ \\
\hline
\end{tabular}

For the Source Catchments model, the climate change scenario for both catchments reveals an average $5 \%$ decrease in annual flow when compared to current climate conditions (Table 5.8; Upper Tukipo comparison shown). The daily flow volumes show a greater variability under future climate conditions, and the overall effect on streamflow is greater as compared to results from the TEDI modelling. This may be a reflection of the higher precision gained by the daily time step used in Source Catchment modelling, but it is likely that the poor representation of seasonality of flow by the AWBM rainfall-runoff model (as discussed previously) is also influencing these results. 


\subsubsection{Other scenarios}

\section{Evaporation losses}

Within TEDI, open water evaporation losses from ponds are calculated using maximum pond area values (i.e. at full capacity) and a water balance approach based on monthly values of evaporation and precipitation. To determine open water evaporation losses, the Upper Tukipo and Upper Tukituki irrigation scenarios were run with no takes from any ponds. In this way, any predicted change to runoff volumes would solely be attributed to evaporation losses from farm pond surfaces. Model predictions using this approach suggest that the influence of pond evaporation on total streamflow volumes is small. Average loss to annual streamflow volume is between $37 \mathrm{ML}$ and $74 \mathrm{ML}$ in the Upper Tukipo catchment and between $330 \mathrm{ML}$ and $660 \mathrm{ML}$ in the Upper Tukituki catchment (under 'Irrigation' and 'Irrigation x 2' scenarios in both catchments respectively). These volumes represent only 0.08 to $0.15 \%$ (Upper Tukipo) and 0.007 to $0.01 \%$ (Upper Tukituki) of total catchment runoff. Monthly evaporation loss is variable, with many months (in both wet and dry seasons) showing no influence on streamflow volumes at all.

\section{Incorporating bypass structures}

One TEDI run was completed using the bypass structure option to ascertain whether or not the incorporation of these structures would replace significant flow volumes to the stream that would otherwise be lost to farm pond storage. During periods of high streamflow, bypass structures allow water to fill ponds, but when flow decreases to a certain threshold (set within the model), flow will bypass ponds and enter the main stream channel directly. Bypass structures are now required on many newly constructed dams in Australia, with bypass levels set to maintain environmental flows. These structures are not required for any farm ponds in New Zealand. 
The 'Irrigation' scenario was run on the Upper Tukipo catchment with bypass structures added to all ponds $>5 \mathrm{ML}$ in volume. A minimum bypass flow of $0.5 \mathrm{ML} / \mathrm{km}^{2}$ was applied to each dam with bypasses activated in the drier months of November through March. Under this scenario, approximately 73 ponds out of a total of 600 would have bypass structures (as bypass structures are only applied to 'future' storage ponds in the model). TEDI predicts that these structures would return an annual average volume of $53 \mathrm{ML}$ back to the main channel. This represents a very small proportion of the 49,000 ML average annual flow on the Tukipo River, but the timing of these returns is important.

The significance of the bypass structures lies in the return of water to the stream during dry months. The modelled average monthly bypass return is $4.4 \mathrm{ML}$ $(1.7 \mathrm{~L} / \mathrm{s})$, and the maximum monthly bypass return is $114 \mathrm{ML}(44 \mathrm{~L} / \mathrm{s})$. Consented streamflow takes are banned on the Tukipo River when streamflow falls below $150 \mathrm{~L} / \mathrm{s}$. Using average daily Tukipo flow data, it was determined that bans would likely have been placed on the river for 77 days between 1999 and 2009. Average predicted bypass returns $(4.4 \mathrm{ML} / \mathrm{d})$ would have augmented streamflow to levels above the minimum required flow on 4 more days. If the modelled maximum bypass return $(114 \mathrm{ML} / \mathrm{d})$ is used, this would have augmented flow to an extent that 73 days out of the total of 77 days would not have reached ban levels, leaving only 4 days below the $150 \mathrm{~L} / \mathrm{s}$ ban level. The results are not precise because average daily flows do not represent minimum flow reached, and bypass flow volumes are only determined on a monthly time step. However, the results do give some indication of how bypass structures may increase streamflow during critical low flow periods. It is suggested that further investigation of bypass options would need to be undertaken before these results could be incorporated into regional management plans. 


\subsection{Conclusion of Regional Analysis}

The purpose of the modelling component of this analysis was to better understand the cumulative effect of small farm pond storages at the regional scale under current and future catchment conditions. Two models were used to estimate the decrease in streamflow volumes on a monthly (TEDI) and daily (Source Catchments) time step for the Upper Tukipo and Upper Tukituki catchments. Because of data constraints, the modelling option within Source Catchments was also based on TEDI principles. A more complete discussion of the drawbacks of and possible improvements to these models is covered in Chapter 6.

Scenario runs using the TEDI model suggest that current pond size distributions and storage volumes in the Upper Tukipo and Upper Tukituki catchments have already decreased annual streamflow volumes by approximately 1\% (524 ML and 4000 ML respectively). Source Catchments modelling has slightly lower proportional impacts because of higher predicted streamflow by the component rainfall-runoff model, but absolute values of streamflow decrease are very similar to TEDI results. The impact of farm dams on streamflow volumes varies monthly, with the highest relative impact occurring in the drier summer months. During the winter months of higher rainfall, pond storages within the catchment have a smaller influence (and sometimes no influence) on streamflow volumes. The daily time step of the Source Catchments model adds a level of detail to the modelling, but still does not represent catchment processes completely. In particular, an analysis of streamflow from a small subcatchment comparable to the regulated field study catchment shows that the model does not capture the period of no flow that was observed throughout the dry summer and autumn in the field study.

The small difference between predicted streamflow volumes for the 'Stock' and 'Irrigation' scenarios suggests that the models are more sensitive to total volumes 
of storage (which were the same for both scenarios) and less sensitive to the size distribution of storages. Under a doubling of pond storage volumes in future scenarios, both models predict a concurrent doubling of streamflow volume loss. This suggests that the TEDI model may be too simplistic in determining future catchment scenarios, as it is not likely that an increase in storage volumes would result in a directly linear decrease in streamflow volumes. It is more reasonable to expect a nonlinear hydrologic response in these instances.

Climate change scenario results from the TEDI model reveal that the predicted changes in seasonal precipitation volumes will not produce any additional effect on streamflow volumes, as compared to current conditions. This suggests that future water demands in the catchment may not be driven by regional changes in climate as expected, but might be influenced more by increases in agricultural intensification and demand for water. Source Catchments modelling shows greater impacts due to climate change, with an annual decrease in streamflow of approximately $5 \%$ for both catchments. The difference in output between the two models is at least partly related to catchment seasonality of flow which is not accurately represented by the component rainfall-runoff model within Source Catchments.

Direct pond evaporation losses, as modelled by TEDI, show that the cumulative influence of evaporation on streamflow volumes is very low. A scenario was also run with bypass structures placed on a number of dams in the Upper Tukipo catchment. The predicted output reveals that the structures do return a small volume of flow to the stream during the dry summer months. This may enhance flow in some instances enough to decrease the number of days that bans for water takes are placed on individual rivers. A more detailed investigation using minimum daily flow data and a finer time-step (instead of the monthly TEDI time-step) would grant a better insight into the benefit these structures might have in ameliorating flow volume in both catchments. 
This modelling investigation has shown that farm dams affect catchment streamflow volumes. Predicted volumes are similar to decreases found in other modelling studies, but are much lower than the difference in observed streamflow volumes between the regulated and unregulated streams as found through the field study investigation. On balance, it seems likely that the models are biased towards underestimating the impacts of dams. At present, the results of this modelling analysis should be viewed as preliminary, with further investigations needed before any strong conclusions on a catchment-wide basis can be made. Model deficiencies and suggested improvements are covered in Chapter 6. 



\section{Discussion of results}

\subsection{Research findings in light of existing knowledge}

The present study has been divided into two components: a paired catchment field study monitoring the effect of three small farm dams on the downstream system; and a catchment-scale modelling investigation on the impact of farm dams on streamflow, using two off-the-shelf models (TEDI and Source Catchments) for the Upper Tukipo and Upper Tukituki catchments, located within the Ruataniwha Plains of the Hawke's Bay region. A summary of results from previous small dam research is compared to results from the field study and regional modelling in Table 6.1. Table 6.2 compares previous research on the effect of small dams on water quality, sediment transfer, and channel morphology to results from the field study. The tables suggest that research results fall largely within the range of previous findings, with exceptions noted below.

The comparisons in Tables 6.1 and 6.2 need to be viewed in light of certain study limitations. Field study limitations are covered in more detail in Chapter 4 and include issues regarding the small temporal and spatial scale of the study (i.e. one year of data collection in two small catchments). The drier than normal conditions during the study period has also limited the number of high flow events that were able to be measured, and led to a low number of samples collected for the analysis of water quality and suspended sediment levels. The samples that were collected and analysed are representative of low to medium flow stages only. The dry conditions also influenced the accuracy of the derived level-discharge relationship, as high flow measures are missing; this may impact the accuracy of derived catchment flow volumes. However, the analysis of bankfull discharge and the Froude number estimates for both streams suggest that 
both the derived level-discharge relationship and the catchment flow volumes are reasonable.

Table 6.1: Summary of previous research on the impact of small dams on streamflow and water balance components, compared to results of the present study (field and modelling components).

\begin{tabular}{|c|c|c|c|}
\hline Parameter & $\begin{array}{l}\text { Previous studies (both } \\
\text { modelling and field- } \\
\text { based) }\end{array}$ & $\begin{array}{l}\text { Field study (regulated } \\
\text { to unregulated } \\
\text { comparison) }\end{array}$ & $\begin{array}{l}\text { Modelling ('Stock' } \\
\text { scenario compared } \\
\text { to no dams in } \\
\text { catchment) }\end{array}$ \\
\hline $\begin{array}{l}\text { annual } \\
\text { runoff }\end{array}$ & $\begin{array}{l}\text { decrease up to } 40 \% \text {; } \\
\text { mean } 10 \% \text { (based on } \\
25 \text { studies); higher loss } \\
\text { in dry months/years }\end{array}$ & $\begin{array}{l}\text { decrease of } 40 \% \text {; higher } \\
\text { loss in dry months }\end{array}$ & $\begin{array}{l}\text { decrease of } 1 \% \\
\text { (both models, both } \\
\text { catchments); higher } \\
\text { loss in dry months }\end{array}$ \\
\hline peak flow & $\begin{array}{l}\text { decrease of } 2 \text { to } 45 \% \\
\text { (Q10) (4 studies) }\end{array}$ & decrease of $20 \%$ & $\begin{array}{l}\text { no significant } \\
\text { change (Source } \\
\text { Catchments) }\end{array}$ \\
\hline low flow & $\begin{array}{l}\text { decrease of } 0.3 \text { to } 27 \% \\
\left(Q_{90}\right) \text { (4 studies) }\end{array}$ & $\begin{array}{l}4 \% \text { decrease of mean } \\
\text { daily baseflow }\end{array}$ & $\begin{array}{l}1.5 \% \text { decrease of } \\
\text { mean daily baseflow }\end{array}$ \\
\hline $\begin{array}{l}\text { variability } \\
\text { of flow }\end{array}$ & $\begin{array}{l}\text { decreased; longer } \\
\text { periods of low flow, } \\
\text { lower peak flows, delay } \\
\text { flow at beginning of } \\
\text { wet period }\end{array}$ & $\begin{array}{l}\text { decreased; longer } \\
\text { periods of low flow, } \\
\text { lower peak flows, delay } \\
\text { of flow at beginning of } \\
\text { wet period (winter) }\end{array}$ & $\begin{array}{l}\text { inconclusive } \\
\text { because of problems } \\
\text { in modelling } \\
\text { seasonality of flow } \\
\text { (Source } \\
\text { Catchments) }\end{array}$ \\
\hline $\begin{array}{l}\text { storm } \\
\text { event } \\
\text { response }\end{array}$ & & slower response & $\begin{array}{l}\text { slower response } \\
\text { (Source } \\
\text { Catchments) }\end{array}$ \\
\hline $\begin{array}{l}\text { seepage } \\
\text { from ponds }\end{array}$ & & $\begin{array}{l}\text { significant; catchment } \\
\text { water balance suggests } \\
\text { loss equivalent to total } \\
\text { volume of pond }\end{array}$ & $\begin{array}{l}\text { models assume } \\
\text { seepage is negligible }\end{array}$ \\
\hline $\begin{array}{l}\text { pond } \\
\text { evaporation }\end{array}$ & $\begin{array}{l}\text { pond evaporation up to } \\
50-70 \% \text { of total pond } \\
\text { storage; water balance } \\
\text { calculation ( } 2 \text { studies) }\end{array}$ & $\begin{array}{l}\text { pond evaporation up to } \\
100 \% \text { of total pond } \\
\text { storage; water balance } \\
\text { estimation }\end{array}$ & $\begin{array}{l}\text { streamflow decrease } \\
\text { of }<0.01 \% \text { (both } \\
\text { models, both } \\
\text { catchments) }\end{array}$ \\
\hline
\end{tabular}

The decrease to annual runoff in the field study's regulated catchment is estimated at $40 \%$, which is equal to the highest decrease reported in previous studies. This may be explained in part by the high density of farm dam storage 
$\left(16 \mathrm{ML} / \mathrm{km}^{2}\right)$ in the study catchment, and by the uncertainty associated with the derived level-discharge relationship. As discussed in Chapter 4, there may also be

Table 6.2: Summary of previous research on the impact of small dams on water quality, sediment transfer, and channel morphology compared to results of the present field study.

\begin{tabular}{|c|c|c|}
\hline Parameter & $\begin{array}{l}\text { Previous studies (both } \\
\text { modelling and field-based) }\end{array}$ & $\begin{array}{l}\text { Field study (regulated to unregulated } \\
\text { comparison) }\end{array}$ \\
\hline $\begin{array}{l}\text { water } \\
\text { quality }\end{array}$ & $\begin{array}{l}\text { downstream decrease in some } \\
\text { variables, increase in others; } \\
\text { trapping of nutrients and } \\
\text { pollutants in ponds (10 studies); } \\
\text { water quality highly dependent } \\
\text { on catchment characteristics }\end{array}$ & $\begin{array}{l}\text { decrease in water quality in } \\
\text { downstream direction and within } \\
\text { pond; generally lower water quality } \\
\text { in regulated stream as compared to } \\
\text { unregulated; influenced by } \\
\text { catchment characteristics }\end{array}$ \\
\hline $\begin{array}{l}\text { downstream } \\
\text { transfer of } \\
\text { sediment }\end{array}$ & $\begin{array}{l}\text { decrease in catchment yield ( } 3 \\
\text { studies); trap efficiency of } \\
\text { ponds up to } 100 \% \text { ( } 5 \text { studies); } \\
\text { highly dependent on catchment } \\
\text { and reservoir characteristics }\end{array}$ & $\begin{array}{l}\text { no significant difference between } \\
\text { suspended solids transport in } \\
\text { unregulated and regulated streams } \\
\text { (but no high flow events measured) }\end{array}$ \\
\hline $\begin{array}{l}\text { channel } \\
\text { degradation }\end{array}$ & $\begin{array}{l}\text { scour and channel armouring } \\
\text { directly downstream of dam }\end{array}$ & no scour or armouring observed \\
\hline $\begin{array}{l}\text { channel } \\
\text { aggradation }\end{array}$ & $\begin{array}{l}\text { aggradation further } \\
\text { downstream of dam }\end{array}$ & $\begin{array}{l}\text { aggradation throughout regulated } \\
\text { channel (estimated rate } 1.5-2 \mathrm{~cm} / \mathrm{y} \text { ); } \\
\text { knickpoint location and height } \\
\text { further evidence of lowered erosion } \\
\text { rates in regulated stream }\end{array}$ \\
\hline $\begin{array}{l}\text { channel } \\
\text { width }\end{array}$ & narrows downstream of dams & narrows downstream of dams \\
\hline $\begin{array}{l}\text { longitudinal } \\
\text { profile }\end{array}$ & no information found & $\begin{array}{l}\text { stronger deviation from graded } \\
\text { concave upward shape in regulated } \\
\text { stream }\end{array}$ \\
\hline
\end{tabular}

some specific catchment characteristics relating to internal water losses that are not being accounted for. Finally, as the study was conducted on a small spatial and temporal scale, the results may change when they are averaged over a number of years and/or if more subcatchments are included in the study. This averaging effect was shown in part through the current modelling investigation and has also been reported in previous studies. For example, a modelling study in Australia found that farm dams reduced catchment streamflow by $10 \%$, but the 
range of subcatchment streamflow reduction was 6-40\% (SKM, 2008). The similarity of results provided in the current study by TEDI and Source Catchments to other modelling results, may also be a reflection of catchment averaging processes. Further limitations to the modelling study and recommendations are covered in more detail in Section 6.2.

A second discrepancy is the fact that no scour, channel armouring, or erosion of any kind was found along the length of the regulated channel. This observation is discussed in detail in Chapter 4. The altered flow regime, including decreases in peak flow runoff, leads to a decrease in stream erosion potential. This is further exacerbated by specific channel characteristics (including vegetation growing within the channel and stock trampling at the channel banks) which lead to a loss of concentrated flow and channel aggradation. It is suggested that this lack of channel erosion downstream of small farm dams may be more common than previously thought.

\subsection{Model drawbacks and input uncertainties}

Models are simplified representations of reality. Depending on the simplifications made, some aspects of the system will be better represented than others. Although a thorough critique of the TEDI and Source Catchments models is beyond the scope of the present study, some of the limitations of the models and how these might affect predicted results are presented. Recommendations on how improvements to data input and model structure might provide more accurate predictions in the future are also included.

All inputs to the TEDI model (and by extension, the farm dam modelling component within Source Catchments) are summarised in Table 6.3. The table includes the level of confidence for each input used in the present study, and a recommendation for future investigations which might lead to an increase in the 
Table 6.3: Input variables for TEDI and Source Catchments models, including general confidence levels for each (as derived in the present study) and suggested future refinements.

\begin{tabular}{|c|c|c|}
\hline Model Input & Confidence in values used & Possible future investigations \\
\hline $\begin{array}{l}\text { Water balance: } \\
\text { precipitation, } \\
\text { PET, AET, } \\
\text { streamflow }\end{array}$ & $\begin{array}{l}\text { High confidence: used large } \\
\text { data sets which were integrated } \\
\text { across the study catchments. }\end{array}$ & N/A \\
\hline $\begin{array}{l}\text { Number of } \\
\text { ponds in } \\
\text { catchments }\end{array}$ & $\begin{array}{l}\text { High confidence: manual } \\
\text { digitisation error analysis } \\
\text { showed no major areas of } \\
\text { concern. }\end{array}$ & $\begin{array}{l}\text { More investigation into automatic } \\
\text { retrieval methods, or the } \\
\text { gathering of data through a farm } \\
\text { dam registration process. }\end{array}$ \\
\hline $\begin{array}{l}\text { Volumes of } \\
\text { ponds (area- } \\
\text { volume } \\
\text { relationship) }\end{array}$ & $\begin{array}{l}\text { Medium to high confidence: } \\
\text { regional equation based on } \\
\text { regional consented dam dataset; } \\
\text { relationship is similar to those } \\
\text { derived elsewhere. }\end{array}$ & $\begin{array}{l}\text { Further development of equation } \\
\text { based on field measures of smaller } \\
\text { dams which are underrepresented } \\
\text { in the regional dataset. }\end{array}$ \\
\hline $\begin{array}{l}\text { Monthly takes } \\
\text { from ponds }\end{array}$ & $\begin{array}{l}\text { Medium confidence: based on } \\
\text { regional estimates and previous } \\
\text { Australian research. }\end{array}$ & $\begin{array}{l}\text { Refine values based on field } \\
\text { measurements and/or regional } \\
\text { surveys of water use. }\end{array}$ \\
\hline $\begin{array}{l}\text { Monthly } \\
\text { demand factor }\end{array}$ & $\begin{array}{l}\text { Medium to high confidence: } \\
\text { estimated, but used a fairly } \\
\text { conservative value. }\end{array}$ & $\begin{array}{l}\text { Refine based on field } \\
\text { measurements and/or a survey of } \\
\text { farmers. }\end{array}$ \\
\hline $\begin{array}{l}\text { Separation } \\
\text { between pond } \\
\text { volumes used } \\
\text { for stock and } \\
\text { irrigation. }\end{array}$ & $\begin{array}{l}\text { High confidence: value based } \\
\text { on Australian studies, but most } \\
\text { ponds in study catchments are } \\
\text { small and would be used for } \\
\text { stock. }\end{array}$ & $\begin{array}{l}\text { Use council's resource consent } \\
\text { database to determine which } \\
\text { ponds are used for irrigation. }\end{array}$ \\
\hline $\begin{array}{l}\text { Upstream } \\
\text { catchment area } \\
\text { of } 5 \mathrm{ML} \text { and } \\
100 \mathrm{ML} \text { ponds }\end{array}$ & $\begin{array}{l}\text { Medium confidence: confident } \\
\text { of method of measurement, but } \\
\text { not confident that a linear } \\
\text { relationship is representative. }\end{array}$ & $\begin{array}{l}\text { Measure further and refine } \\
\text { relationship; investigate the } \\
\text { validity of a linear relationship. }\end{array}$ \\
\hline $\begin{array}{l}\text { Farm dam } \\
\text { distributions }\end{array}$ & $\begin{array}{l}\text { High confidence: measured } \\
\text { from digitised pond data using a } \\
\text { GIS platform. }\end{array}$ & \\
\hline $\begin{array}{l}\text { AWBM rainfall- } \\
\text { runoff } \\
\text { component } \\
\text { model }\end{array}$ & $\begin{array}{l}\text { Low confidence: model does } \\
\text { not accommodate the } \\
\text { seasonality of catchment flow; } \\
\text { annual values overestimated. }\end{array}$ & $\begin{array}{l}\text { Adding seasonality to the model } \\
\text { will improve streamflow output } \\
\text { considerably. }\end{array}$ \\
\hline
\end{tabular}


confidence levels of these input variables. Specific limitations relating to model structure are discussed further below.

Overall, the confidence level of model inputs is fairly high. It is suggested that the most gains in accuracy of model output will be made by refining the areavolume relationship and finding a rainfall-runoff model that is more representative of catchment characteristics, particularly of the seasonality of flow. However, before further investigations into improving model input are made, an analysis of the applicability of the models to hydrological processes in the study catchments should be completed. It is suggested that the major limitations of both models lie within the assumptions of model structure, rather than the precision of model input values. As noted in Chapter 5, both models seem to be biased towards underestimating the influence of farm dams on streamflow volumes. Specific model assumptions that would be prudent to investigate further are outlined below, along with the likely change to modelled output if these processes are incorporated into the modelling framework.

In the TEDI model, outflow from each pond is directed separately to the catchment outlet, which does not allow for the representation of flow routing through a cascade of dams on the same stream. While the Source Catchments model directs outflow from each pond to the corresponding subcatchment outlet, this added level of refinement still underestimates farm pond impact in any subcatchment that has numerous dams located on the same stream. Such a cascade of ponds means that they will fill and spill in turn, shifting the timing of flow events in a complex and overlapping manner. However, adding in discrete flow routing to the models may not add precision to output volumes in catchments where multiple dams on the same stream are not common. Discrete routing will nevertheless influence the timing of flow, particularly at the beginning and end of the wet season. This may be an important modelling consideration if catchment water managers need to predict and maintain streamflow volumes at specific times of the year. 
In both models there are a number of water balance assumptions that may not be valid in relation to catchment characteristics within the present study. The model assumption of negligible pond seepage is unlikely to be valid, as suggested by the significant pond seepage estimated from the field study. As well, the assumption of no transmission losses or gains along the stream channel is also unlikely to be valid as there are known gaining reaches on both the Tukipo and Tukituki Rivers. Based on field estimates of open pond evaporation, it is also likely that direct pond evaporation is underestimated in model calculations. If all three of these components were fully incorporated into the models, predictions would show a higher reduction in streamflow as a direct result of catchment farm dams. Internal catchment characteristics are not sufficiently captured in either model. The variability of regional precipitation and its close link to runoff volume and timing means that the monthly time step of TEDI is insufficient to accurately capture catchment rainfall-runoff processes. These processes are also inadequately captured in Source Catchments because the component rainfallrunoff model (AWBM) does not accurately represent flow volume and timing throughout the year. If low flows were better represented during dry months (and not overestimated as they are currently), there would be a greater proportional impact by farm dams on streamflow at the catchment outlet.

The combination of these model shortcomings is reflected in the underestimation of pond drawdown throughout the summer. The slow draining of the ponds over the summer (as observed in the field study) left a long period of no runoff, even when large rainfall events occurred. Predicted streamflow from one subcatchment using the Source Catchments model showed a continuous response throughout the dry summer, a period when no flow was observed in the field study catchment. The over prediction of low flows by the AWBM component model explains this discrepancy in part, but there may be a more complex interaction between surface water and baseflow at times of extreme dryness which cannot be captured by simplified process modelling. This may mean that 
the fundamental processes underlying the models are at present too simplistic to represent the response of streamflow to precipitation events in this region.

Overall, TEDI is a simple model to run, with most input data available through national scale datasets and existing regional council data. Predicted results seem reasonable for the catchments under study when broadly compared to observed field results (summarised in Chapter 4) and other modelling studies (summarised in Chapter 2), although it is suggested that TEDI tends to underestimate the impact of farm dams on catchment streamflow. The simplicity of the model may not be useful for some management applications. The monthly time step and spatial lumping results in a very coarse approximation of water losses to the catchment. Average catchment values at this scale do not reflect internal catchment characteristics or specific tributary streams which may be impacted more intensely if pond storages are not evenly distributed throughout the catchment. Management practices are not always applied on a catchment-wide scale. In some instances, especially in the management of water quality, distinct areas can be managed towards a specific aim. The lumped and averaged model output of TEDI would not be precise enough to allow for such site specific investigations to be made.

The strength of the Source Catchments model is its ability to predict impacts at catchment and subcatchment outlets at a daily time step. Unfortunately, in the present study it was found that the added spatial and temporal precision did not equate to a further refinement of modelled results. If farm ponds were modelled individually instead of using a semi-lumped approach based on TEDI principles (as was completed in the present study), Source Catchments would be a more useful model for farm dam applications. However, model input requirements will likely preclude its use in most instances in New Zealand. Necessary information for each farm dam in the catchment includes inflow into the pond, groundwater inputs and losses, spills from the pond, water discharge at various pond depths, and a minimum outlet capacity table. Since most regional councils do not have 
any data on small farm dams which do not require resource consent (and in some cases, no post-construction data from those that do), the collection of this input data would be a massive undertaking.

Further work on finding a useful model for the Ruataniwha Plains area will be necessary to provide adequate tools for water management. If a more accurate and representative model is found, it is expected that revised model outputs would indicate that the current storage volume of farm ponds in the catchments have a higher impact on downstream volumes than is predicted within the current regional modelling investigation.

\subsection{Recommendations}

This study has shown that farm dams decrease downstream flow volumes, which in turn may influence aspects of water quality, sediment transfer, and channel morphology. These impacts will further influence downstream ecology, including species richness, diversity, and habitat. There are a number of recommendations for the management of farm dams that can be made specifically for the Ruataniwha Plains and more generally for other agricultural areas of New Zealand.

1. Farm dam inventory: The overall impact of farm dams will depend on the number of dams in the catchment and the total volume of water stored. It is important from the outset that an inventory of all water storages in the region under study is made and maintained. This inventory should include information on all farm ponds and their location, surface area, volume, depth of outflow culvert, use, and takes (volume and timing). A database containing this information would be invaluable for further catchment modelling. This would greatly assist water managers in making regional water management decisions.

2. Use of ponds to improve water quality: Previous studies have shown that with proper management (including sizing of ponds and their placement within the 
catchment), farm ponds can improve downstream water quality by trapping and filtering nutrients, bacteria, and sediment. Further improvements are made when stock is excluded from the ponds and riparian plantings are established. However, there are limitations to the effectiveness of small ponds in decreasing the supply of particulates and constituents to downstream reaches, and land in the upstream catchment must also be properly managed. Further study on the influence of farm dams on water quality, including the monitoring of nutrients and sediment (which were not covered in the current study) will add greatly to existing knowledge and further aid in developing management plans for farm dams.

\section{Management of storages to minimise water loss: There are a number of} methods which can minimise water loss from ponds, including reducing pond seepage with pond liners and reducing evaporation losses by building deeper reservoirs that have smaller surface areas, thereby decreasing water losses to direct evaporation. Implementing bypass structures to return flow to downstream reaches during critical low flow periods may also be a management consideration. Bypass structures are effective in that they decrease the downstream impacts on flow without having to remove dams from the catchment. However, the benefits of these management options must also be balanced with the cost of their implementation. Further study on the benefits and costs of these management options should be completed.

4. Model refinement: Because modelling is so useful for investigating management options and developing management strategies, more work should be done to find (and/or develop) a representative regional model of farm dam impacts which will capture important catchment processes. A useful model would balance ease of use with an accurate representation of catchment processes and impacts of farm dams on catchment streamflow. From a water management perspective, this model could be used to inform decisions based on the impact on streamflow of current and future dams in the catchment. Additional model components that would be useful include the ability to model changes to water 
quality and sediment transfer as water is routed through individual water storages. It is suggested that a spatially discrete model run at a daily time step and based on sound scientific knowledge of catchment processes would give managers the best possible information upon which to base decisions.

5. Further investigations: There are a number of further investigations that can be made to better inform catchment water management plans. In particular, it would be useful to determine the difference in the effect of farm dams on perennial streams and those on intermittent streams, as well as the difference in downstream impacts between onstream and offstream storages. The question of climate change impacts should also be investigated further as no conclusive statement could be made within the current modelling investigation. It is particularly important to first incorporate the predicted change to rainfall timing and intensity (i.e. the predicted fewer storms of greater intensity), as these changes will influence the timing of stormflow, the transfer of sediment, and the overall quality of stream water. In the future, it might be beneficial and cost effective to use these small storages as flood retarding ponds to delay the large stormflow contributions predicted under climate change scenarios. However, this use of farm ponds must also be balanced with a host of other interacting variables which would be affected by any further farm dam construction. 



\section{Conclusion}

Although it has been estimated that there are millions of small dams worldwide, and tens of thousands of small dams in New Zealand, no extensive or complete body of scientific literature exists on the effects these small dams have on the environment. With global water scarcity issues developing in part due to agricultural intensification and climate change, these small dams will continue to be constructed, and their cumulative effect will continue to impact the flow regime and influence related downstream processes. The purpose of this research was to determine the impact of small farm dams on the larger system. A paired catchment field study was completed to investigate the effect of small dams on streamflow regime, water quality, sediment transfer, and channel morphology. The regional modelling study was completed to determine the cumulative effect of farm dams on streamflow at the larger catchment scale. The results of both investigations reveal that small farm dams affect the larger system in a variety of ways. The extent of this impact includes influences on the timing and volume of streamflow, changes to stream and pond water quality, changes to the calibre of sediment transferred, and shifts to channel morphology. The main findings of each of the research objectives (as outlined in Chapter 1) and a summary of suggested management options in light of these findings are the focus of this chapter.

\subsection{Field study research objectives}

\section{How does regulation by small dams affect the timing and volume of flow reaching the catchment outlet?}

Results from the paired catchment field study reveal that the annual volume of flow in the regulated catchment is approximately $40 \%$ lower than that of the adjacent unregulated catchment. The total volume of flow for both streams is 
based on derived level-discharge relationships, calculated for the hydrologic year Aug 1, 2008 to Aug 1, 2009. Annual streamflow volumes are $360 \mathrm{ML} / \mathrm{km}^{2}$ for the unregulated stream and $216 \mathrm{ML} / \mathrm{km}^{2}$ for the regulated stream. A lower volume of flow on the regulated stream is expected; the difference in flow volume is attributed to a combination of pond storage, seepage, evaporation, and water takes. However, after estimating these losses using the annual catchment water balance, there is still an unaccounted water loss of approximately $88 \mathrm{ML} / \mathrm{km}^{2}$ on the regulated stream. This water loss is partly explained by uncertainties in the derived level-discharge relationship (upon which all volume measurements are based) and uncertainties in the estimation of water losses in the catchment. Additionally, there may be unknown catchment processes (such as groundwater movement between the two catchments) which are not accounted for. This latter explanation is supported by the modelling study which suggests that there are seasonal changes in hydrological processes in the study catchments.

Regulation has also changed the timing of flow. Downstream flow on the regulated channel is present only when the ponds are full and overflowing. This results in a delay of flow commencement at the end of the dry season (when ponds are filling) and a delay of flow cessation at the end of the wet season (as pond levels slowly fall below outlet levels), as compared to the unregulated stream. Although total flow volumes are lower on the regulated stream, the number of days of measured flow is double that of the unregulated stream. In both the unregulated and regulated catchments, no flow was observed throughout the drier than normal summer and autumn period (Dec, 2008 to May, 2009). Discharge measurements at the regulated catchment outlet also show a decrease in peak runoff volumes, an increase in periods of low flow, and a slower streamflow response to storm events. All of these findings support previous small farm dam research (as summarised in Chapter 2) although estimated regulated catchment losses are higher than reported in other studies. 


\section{How do changes to the flow regime caused by small farm dams affect sediment transfer and channel morphology?}

In the paired catchment field study, suspended solids were not measured under high discharge events, so a comparison across a full range of streamflow volumes cannot be made. However, at low to medium flows, suspended solids concentrations on both the unregulated and regulated streams are low and there is no significant difference in suspended solids concentrations found between the two catchments.

Major differences are found in channel bed sediments, with much finer sediment in the regulated stream channel $\left(\mathrm{d}_{50}=-2.76 \varphi\right.$; fine sand), as compared to the unregulated stream channel ( $\mathrm{d}_{50}=-3.53 \varphi$; pebble). Although this difference may partly be attributed to differences in catchment sediment sources, the calculated stream power potentials suggest that coarser material could be transported by the regulated stream. Even in areas where coarser sediment is available (i.e. downstream of the knickpoint location), it is still not transported. Average rates of sediment deposition on the regulated channel are estimated at 1.5 to $2 \mathrm{~cm} / \mathrm{y}$ over the period of regulation (approximately 40 years).

Sediment pits located on the regulated stream show a slight coarsening upwards of sediment calibre over time. The coarsening upward sequence may be a result of slightly coarser sediment becoming available for transport and subsequent deposition. As there is no concurrent increase in rainfall volumes or intensities, this is likely related to a change in land use (i.e. intensification of agricultural practices) and/or a decrease in vegetation cover in the study catchment, both of which have occurred in the post-regulation period.

Other differences between the unregulated and regulated streams include a narrowing of the regulated stream channel in the downstream direction, as compared to a downstream widening of the unregulated channel. This narrowing has been found in other regulated flow studies and is related to changes to stream 
power as a result of decreased post-regulation flow volumes. No major change in channel sinuosity between the unregulated and regulated channels is detected.

No scour or armouring is observed on the regulated stream channel. This differs from previous studies which suggest that scour should be present directly downstream of dams of any size. Aggradation is observed over the entire length of the regulated stream channel. Although stream velocities on the regulated stream should be able to transport the channel bed sediment, the channel is unable to contain large flow volumes because of the combination of channel form (wide shallow channels), stock access to streams (leading to bank erosion and the creation of indistinct channels), and vegetation cover (lowering channel erosion potentials). These factors promote a lack of concentrated flow and effectively prevent erosion and downcutting from occurring on the regulated channel.

A decrease in erosion rates on the regulated stream is also supported by the differences in longitudinal profile and knickpoint location between the two systems. The knickpoint on the regulated stream is located further downstream and is higher in elevation, as compared to the knickpoint on the unregulated stream, suggesting a slower rate of upstream knickpoint migration on the regulated stream. These observed morphological differences result from lower rates of channel erosion due to changes in flow regime and stream power. These, in turn, are attributed to a former truncation of the regulated stream's head and to the more recent regulation of the stream by the farm dams.

\section{Are there significant water quality differences between the regulated and unregulated streams? How does water quality change within the ponds over time?}

Because of the intermittent nature of catchment streamflow and the lower than average precipitation volumes over the study period, there are not enough water quality samples to provide a robust comparison between the two catchments. However, it is observed that differences in water quality exist. The most degraded 
water quality values are found within the ponds at low water levels during the dry summer period, with water temperature, $\mathrm{DO}$, and $\mathrm{pH}$ levels falling below recommended levels on a number of occasions. The highest values of TDS and EC (i.e. most degraded) are measured in Ponds B and C. Values of $\mathrm{pH}$, TDS, and EC are similar at the catchment outlets of the unregulated and regulated streams. Dissolved oxygen levels are generally higher at the regulated stream outlet, likely because of greater stream mixing and aeration associated with the knickpoint location just upstream of the water quality measuring site. Water quality on the regulated stream generally shows a slight improvement in the downstream direction, in some cases returning to upstream levels before leaving the catchment. No water quality measurement fell below recommended levels on the unregulated stream, although fewer samples were available because of the more intermittent nature of its flow. Although a definitive conclusion cannot be made on water quality differences between the two catchments, results suggest that internal catchment characteristics and pond placement within the catchment do influence water quality values.

\section{How are these changes affected by having multiple dams on the same stream?}

No specific investigation was undertaken to determine if impacts are greater when there is more than one dam located on the same stream. It is likely that a series of ponds will have a variable effect on the system (as compared to one pond), depending on the sizes of dams and reservoirs, and the magnitude of flow interruption. For example, the larger available storage volume of Pond B took longer to fill at the beginning of the wet season, so flow from Pond C (further downstream) began earlier, complicating the timing and volume of stream response to storm events.

Multiple dams on the same stream may also have a beneficial effect, particularly in terms of improving water quality and trapping nutrients and sediment in ponds. In the study catchment, the highest TDS values were measured within the ponds, suggesting that there is some degree of trapping occurring, which might 
improve overall water quality further downstream. However, the volume of material trapped still depends on the relationship between the volume of water moving through the system and the volume being stored in the pond. As well, the potential benefits of constructing more ponds for this purpose must be balanced with the influence of additional water storages in the catchment and their impact on downstream flow volumes and associated processes.

\subsection{Regional analysis research objectives}

\section{How does the current distribution of farm ponds affect streamflow volumes?}

Modelled streamflow as determined by TEDI and Source Catchments suggests that the current distribution and volume of farm ponds in the Upper Tukipo and Upper Tukituki catchments affect streamflow volumes. The average annual decrease in streamflow resulting from the current distribution of farm ponds in the Upper Tukipo catchment is $1 \%(524 \mathrm{ML} / \mathrm{y})$ as modelled by TEDI and $0.6 \%$ (531 ML/y) as modelled by Source Catchments. A maximum monthly decrease of $13 \%(102 \mathrm{ML} / \mathrm{m})$ was modelled by TEDI, and a maximum daily decrease of $24 \%$ (14 M/d) was modelled by Source Catchments. Slightly lower magnitudes are predicted for the Upper Tukituki catchment, likely because it has a lower density of farm dams as compared to the Upper Tukipo catchment. The similarity in output between the two models is explained by the fact that the farm dam component run in the Source Catchments model is based on TEDI modelling principles.

In months of high rainfall (primarily during the winter), TEDI model predictions show no farm dam influence on catchment outflow. This is reasonable, as ponds would be full and overflowing at this time, with no disconnection of the stream or reduction in flow volume. A similar trend in streamflow timing was found in the field catchment study, although total streamflow volumes were still lower throughout the winter as compared to unregulated streamflow volumes. 
Source Catchments modelling allows for an investigation of streamflow response at a finer temporal resolution (daily rather than monthly). Daily flow response to large storm events led to higher catchment outflow volumes as compared to model runs with no dams. This suggests that the ponds act to extend the time of stormflow recession, a finding that is supported by observations from the field study. However, a more detailed comparison on a storm event basis was not possible because the rainfall-runoff component model was found to under predict high flows and over predict low flows in both catchments. If this seasonality effect was resolved, a more precise indication of the effect of farm dams on streamflow in the catchment could be made.

The decrease in catchment flow volume, as predicted by both models, is much lower than was found in the field study. This is likely explained by a number of reasons. First, the density of pond storage in the field study catchment is much higher $\left(16 \mathrm{ML} / \mathrm{km}^{2}\right)$ than the density of farm pond storage in the Upper Tukipo (8 $\left.\mathrm{ML} / \mathrm{km}^{2}\right)$ and Upper Tukituki $\left(6.5 \mathrm{ML} / \mathrm{km}^{2}\right)$ catchments. Second, there is some uncertainty associated with derived field streamflow volume estimates which may result in an overestimation of field catchment flow volumes. Finally, it is equally possible that the lower influence is also a reflection of the model structure and basic TEDI modelling principles. An investigation into model assumptions and limitations does suggest that if catchment characteristics were better represented in both models, a higher predicted farm dam impact on streamflow would result.

\section{How would future scenarios of continued land intensification and climate change affect catchment streamflow volumes?}

Future catchment scenarios represent agricultural intensification in the region, including a doubling of water storage volumes and a shift to fewer but larger storages to be used for irrigation. Under these scenarios, the models predict a greater decrease in streamflow volume, although there is no significant difference between runs with a greater number of smaller ponds (used for stock) and those 
with a smaller number of larger ponds (used for irrigation). This suggests that the TEDI model is more sensitive to changes in total volume of storage than to the distribution of storage size.

Climate change scenarios represent climate change predictions to 2040 (A1B scenario for the Hawke's Bay region) and suggest a decrease in precipitation during the wetter seasons (winter, spring) and an increase in precipitation during the drier seasons (summer, autumn), with an overall decrease in annual precipitation (MFE, 2008). Catchment precipitation volumes were altered to account for these predictions, although the changes did not capture predicted changes to storm timing and intensity. Results from TEDI climate change scenarios predict that the effect of farm dams will have no more influence in the future than occurs under current precipitation volumes. Modelled results from Source Catchments suggest that the effect of farm pond regulation is greater under future climate change scenarios (as compared to TEDI predictions), although this may be somewhat skewed because of the interaction of predicted seasonal changes with the imprecise modelling of seasonal flow by the component rainfall-runoff model. A further investigation using a more precise rainfall-runoff model within Source Catchments and including the changes to storm timing and intensity (rather than just total volumes) will result in a more robust conclusion on the influence of farm dams under these predicted changes to climate.

\section{Can guidance be provided on the appropriate model structure for assessment of farm dam impacts at the catchment scale?}

The nature of the temporal and spatial lumping within the TEDI model does not allow insight into the influence of farm dams on internal catchment characteristics. The higher temporal and spatial resolution available with the Source Catchments model will offer resource managers a more flexible predictive output which would likely be more useful in developing regional management plans. However, in the present study, the farm dam modelling option used within 
Source Catchments is based on TEDI principles, so any drawbacks to the TEDI modelling structure is repeated in the Source Catchments modelling. A second modelling method within Source Catchments allows farm dams to be input into the model individually and data requirements include daily stream inflow to the pond, groundwater fluxes, pond outflow, the relationship between pond level and discharge, and an outlet capacity table. It is suggested that these input requirements are sufficiently high to preclude its use in New Zealand until such a time as complete data sets on farm dam characteristics are compiled.

In conclusion, it is suggested that the TEDI model is not useful enough to warrant its use in the present circumstances. The Source Catchments model did not offer any further insight into catchment behaviour, primarily because the rainfallrunoff component model did not capture the seasonality of flow in the catchments. If this could be rectified, Source Catchments may provide a better modelling option for managers, but it must at all times be compared to known catchment responses to determine its accuracy and applicability.

\subsection{Summary}

Small water storages allow farmers to add to the security of their on-farm water supply by having water where and when it is needed. Although one small farm dam will not have a great influence on catchment processes, the cumulative impact of multiple farm dams can have a significant effect on the catchment flow regime and associated processes. These effects have been outlined in the present study at the small paired catchment scale and at the larger regional scale. While the effect of farm dams can be significant, impacts can also be mitigated to some degree through proper management techniques. A balance needs to be found between the water requirements of farmers and the needs of other catchment users (including the environment). Unfortunately, in most cases water storages are built (and continue to be built) without proper management tools and policies in place prior to their construction. As has occurred elsewhere (e.g. Australia, 
USA), farm pond management plans are most often developed as a reactive measure, and implemented only after the farm ponds have been found to have a significant impact on the downstream system. Increased farm dam construction, agricultural intensification, and climate change need to be viewed as overlapping concerns and considered in tandem when developing management plans and policies. If policies are developed which balance environmental, economic, social, and technical considerations, farm dams can provide water security into the future without undue wider environmental impacts. 


\section{References}

Al-Nuaimi, H. S., and A. A. Murad (2007), The role of dams in securing the surface water in the northern and eastern parts of the United Arab Emirates (UAE), in Changes in Water Resources Systems: Methodologies to Maintain Water Security and Ensure Integrated Management, edited by N. Van de Giesen, X. Jun, D. Rosbjerg and Y. Fukushima, pp. 206-214, International Association of Hydrological Sciences, Perugia.

Alexander, R. B., H. E. Alexander, U. Shankar, and G. B. McBride (2002), Estimating the sources and transport of nutrients in the Waikato River Basin, New Zealand, Water Resources Research, 38(12), 1268-1291.

Allan, J. D., D. L. Erickson, and J. Fay (1997), The influence of catchment land use on stream integrity across multiple spatial scales, Freshwater Biology, 37, 149-161.

Anderson, E. P., M. C. Freeman, and C. M. Pringle (2006), Ecological consequences of hydropower development in Central America: Impacts of small dams and water diversion on neotropical stream fish assemblages, River Research and Applications, 22, 397-411.

Argent, R., et al. (2008), WaterCAST User Guide, eWater Catchment Research Centre, Canberra.

Arnold, J., R. Srinivasan, R. Muttiah, and J. Williams (1998), Large-area hydrologic modeling and assessment: Part 1. Model development, Journal of the American Water Resources Association, 34(1), 73-89.

Arthington, A. H., and B. J. Pusey (2003), Flow restoration and protection in Australian rivers, River Research and Applications, 19, 377-395.

Auckland Regional Council (2010), Auckland Regional Plan: Air, Land and Water, Auckland Regional Council, Auckland.

Ausseil, O. (2008), Water quality in the Tukituki catchment - State, trends and contaminant loads, Hawke's Bay Regional Council, Napier.

Australia Government, and National Water Commission (2007), A baseline assessment of water resources for the National Water Initiative Level 2 Assessment, Water Availability Theme, Australia Government and National Water Commission, Canberra. 
Australian Water Association (2007), Water in Australia: Facts \& Figures, Myths \& Ideas, Australian Water Association, Sydney.

Baalousha, H. (2009), Stochastic water balance model for rainfall recharge quantification in Ruataniwha Basin, New Zealand, Environmental Geology, 58(1), 85-93.

Baalousha, H. (2010), Ruataniwha Basin transient groundwater - surface water flow model, Plan Number 4234, Environmental Management Group Technical Report, Hawke’s Bay Regional Council, Napier.

Baginska, B., P. S. Cornish, E. Hollinger, G. Kuczera, and D. Jones (1998), Nutrient export from rural land in the Hawkesbury-Nepean catchment, in 9th Australian Agronomy Conference, edited by D. Michalk and J. Pratley, Charles Sturt University, Wagga Wagga.

Baker, D. W., B. P. Bledsoe, C. M. Albano, and N. L. Poff (2011), Downstream effects of diversion dams on sediment and hydraulic conditions of Rocky Mountain streams, River Research and Applications, 27, 388-401.

Barringer, J., D. Pairman, and S. McNeill (2002), Development of a highresolution digital elevation model for New Zealand, Contract Report LC0102/170, Foundation for Research, Science \& Technology, Wellington.

Bates, B. C., Z. W. Kundzewicz, S. Wu, and J. P. Palutikof (Eds.) (2008), Climate Change and Water, IPCC Secretariat, Geneva.

Beavis, S., and M. Howden (1996), Effects of farm dams on water resources, National Landcare Program Project, Bureau of Resource Sciences, Canberra.

Benson, M. (2010), Ruataniwha Plains water storage feasibility study: Demand for irrigation water, Hawke's Bay Regional Council, Napier.

Beschta, R. J., and W. S. Platts (1986), Morphological features of small streams: significance and function, Water Resources Bulletin, 22(3), 369-379.

Bere, T. (2007), The assessment of nutrient loading and retention in the upper segment of the Chinyika River, Harare: Implications for eutrophication control, Water South Africa, 33(2), 279-284.

Beven, K. (2001), Rainfall-Runoff Modelling: The Primer, John Wiley \& Sons, Toronto. 
Beven, K. (2008), On doing better hydrological science, Hydrological Processes, 22, 3549-3553.

Beven, K., and A. Binley (1992), The future of distributed models: Model calibration and uncertainty prediction, Hydrological Processes, 6, 279-298.

Billington, K., and S. Kotz (1999), Inventory of farm dams in the Marne Catchment, South Australia, in 2nd Australian Stream Management Conference, edited by I. Rutherfurd and R. Bartley, pp. 63-67, Cooperative Research Centre for Catchment Hydrology, Adelaide.

Blackham, D., I. Rutherfurd, and M. Stewardson (2009), The role of grassy vegetation in controlling the erosion of fluvial surfaces, paper presented at 7 th International Conference on Geomorphology, Australian and New Zealand Geomorphology Group, Melbourne.

Bosch, N. S. (2008), The influence of impoundments on riverine nutrient transport: an evaluation using the Soil and Water Assessment Tool, Journal of Hydrology, 355, 131-147.

Boughton, W. (2004), The Australian water balance model, Environmental Modelling \& Software, 19, 943-956.

Bovee, K., and T. Cochnauer (1977), Development and evaluation of weighted criteria: Probability-of-use curves for instream flow assessments, Report FWS/OBS-77/63, United States Fish and Wildlife Service, Fort Collins.

Bowling, L.C., P. Storck, and D.P. Lettenmaier (2000), Hydrologic effects of logging in western Washington, United States, Water Resources Research, 36(11), 3223-3240.

Boyd, C. E. (2000), Water Quality: An Introduction, Kluwer Academic Publishers, Boston.

Braatne, J. H., R. Jamieson, K. M. Gill, and S. B. Rood (2007), Instream flows and the decline of riparian cottonwoods along the Yakima River, Washington, USA, River Research and Applications, 23, 247-267.

Brainwood, M., and S. Burgin (2006), An exploration of the relationships between macroinvertebrate community composition and physical and chemical habitat characteristics in farm dams, Environmental Monitoring and Assessment, $119,459-480$. 
Brandt, S. A. (2000), Prediction of downstream geomorphological changes after dam construction: A stream power approach, Water Resources Development, 16(3), 343-367.

Bredehoeft, J. D. (2002), The water budget myth revisited: Why hydrogeologists model, Groundwater, 40(4), 340-345.

Breuer, L., et al. (2009), Assessing the impact of land use change on hydrology by ensemble modeling (LUCHEM). 1. Model intercomparison with current land use, Advances in Water Resources, 32, 129-146.

Bright, J., and M. Morgan (2003), The need for storage to meet future agricultural water demand, paper presented at Dams - consents and current practice, New Zealand Society of Large Dams, Wellington.

Brodnax, R. (2007), The next chapter in regional policy development to manage adverse effects of land use intensification, in Designing sustainable farms: critical aspects of soil and water management, edited by L. Currie and L. Yates, pp. 41-49, Fertilizer and Lime Research Centre, Massey University, Palmerston North.

Brookes, A. (1996), River channel change, in River Flows and Channel Forms, edited by G. E. Petts and P. Calow, pp. 221-242, Blackwell Science, Oxford.

Brooks, A.P., G.J. Brierley, and R.G. Millar (2003), The long-term control of vegetation and woody debris on channel and flood-plain evolution: insights from a paired catchment study in southeastern Australia, Geomorphology, 51, 7-29.

Brown, A.E., L. Zhang, T.A. McMahon, A.W. Western, and R.A. Vertessy (2005), A review of paired catchment studies for determining changes in water yield resulting from alterations in vegetation, Journal of Hydrology, 310, 28-61.

Brown, L. (2002), Ruataniwha Plains Groundwater Exploration Well Results, Hawke's Bay Regional Council, Napier.

Brune, G. (1953), Trap efficiency of reservoirs, Transactions of the American Geophysical Union, 343(3), 407-418.

Bulman, T. L. (2004), Water management in the west: Controlling the impact of cumulative pond diversions, in World Minds: Geographical Perspectives on 100 Problems, edited by D. G. Janelle, B. Warf and K. Hansen, pp. 375-379, Kluwer Academic Publishers, Dordrecht. 
Burt, T. (1996), The Hydrology of Headwater Catchments, in River Flows and Channel Forms, edited by G. Petts and P. Calow, pp. 6-31, Blackwell Science, Oxford.

Charlton, R. (2008), Fundamentals of Fluvial Geomorphology, Routledge, London.

Chen, C.-N., C.-H. Tsai, and C.-T. Tsai (2007), Reduction of discharge hydrograph and flood stage resulted from upstream detention ponds, Hydrological Processes, 21, 3492-3506.

Chilton, R. L., M. M. Hackler, S. R. Smith, D. R. Orvos, and R. K. R. Ambers (2004), A small dam with a big impact: Geomorphology and ecology of two second-order streams in central Virginia, Geological Society of America Abstracts, 36(2), 63.

Chorley, R., and M. Carson (1969), Introduction to fluvial processes, Methuen \& Co, Bungay, Suffolk.

Clark, M., D. Rupp, H. Tromp-van Meerveld, N. Peters, and J. Freer (2009), Consistency between hydrological models and field observations: linking processes at the hillslope scale to hydrological responses at the watershed scale, Hydrological Processes, 23, 311-319.

Collier, K., A. Cooper, R. J. Davies-Colley, J. Rutherford, C. Smith, and R. Williamson (1995), Managing Riparian Zones: A contribution to protecting New Zealand's rivers and streams, Department of Conservation, Wellington.

Cooke, J. G., and A. B. Cooper (1988), Sources and sinks of nutrients in a New Zealand hill pasture catchment. III. Nitrogen, Hydrological Processes, 2, 135-149.

Cooke, R. U., and J. C. Doornkamp (1990), Geomorphology in environmental management, 2 ed., Clarendon Press, Oxford.

Cooke, S. E., and E. E. Prepas (1998), Stream phosphorus and nitrogen export from agricultural and forested watersheds on the Boreal Plain, Canadian Journal of Fisheries and Aquatic Sciences, 55, 2292-2299.

Cooper, C., and S. Knight (1990), Nutrient trapping efficiency of a small sediment detention reservoir, Agricultural Water Management, 18, 149-158.

CRC for Catchment Hydrology (2004), Rainfall Runoff Library User Guide, Cooperative Research Centre for Catchment Hydrology, Melbourne. 
CRC for Catchment Hydrology (2005) Water quality models - sediment and nutrients, Cooperative Research Centre for Catchment Hydrology, Melbourne.

Cresswell, D. (1991), Integrated management of farm dams in the Barossa Valley, Report ESW 87/54, Engineering and Water Supply Department, Government of South Australia, Adelaide.

Croke, B. F. W., and A. J. Jakeman (2008), Use of the IHACRES rainfall-runoff model in arid and semi-arid regions, in Hydrological Modelling in Arid and SemiArid Areas, edited by H. Wheater, S. Sorooshian and K. D. Sharma, pp. 41-48, Cambridge University Press, Cambridge.

Culler, R. C. (1961), Hydrology of stock-water reservoirs in Upper Cheyenne River basin, Geological Survey Water-Supply Paper 1531A, US Geological Survey, Washington, DC.

Dare, P., C. Fraser, and T. Duthie (2002), Application of automated remote sensing techniques to dam counting, Australian Journal of Water Resources, 5(2), 195-208.

Davie, T. (2004), Soil water, runoff and streamflow generation, in Freshwaters of New Zealand, edited by J. Harding, P. Mosley, C. Pearson and B. Sorrell, pp. 4.14.10, NZ Hydrological Society and NZ Limnological Society, Christchurch.

Dendy, F. E., and C. M. Cooper (1984), Sediment trap efficiency in a small reservoir, Journal of Soil and Water Conservation, 39, 278-280.

Downing, J. A., et al. (2006), The global abundance and size distribution of lakes, ponds, and impoundments, Limnology and oceanography, 51(5), 2388-2397.

Duan, Q., S. Sorooshian, and V. Gupta (1992), Effective and efficient global optimization for conceptual rainfall-runoff models, Water Resources Research, 28(4), 1015-1031.

Dubreuil, P., and G. Girard (1973), Influence of a very large number of small reservoirs on the annual flow regime of a tropical stream, in Man-Made Lakes: Their Problems and Environmental Effects, edited by W. C. Ackerman, G. F. White and E. B. Worthington, American Geophysical Union, Washington, DC.

Dunn, S., J. Freer, M. Weiler, M. Kirkby, J. Seibert, P. F. Quinn, G. Lischeid, D. Tetzlaff, and C. Soulsby (2008), Conceptualization in catchment modelling: simply learning?, Hydrological Processes, 22, 2389-2392. 
Eden, A. J. (2006), Water Body Classification: The Manuherikia Catchment, unpublished work.

Edwards, T. K., and G. D. Glysson (1999), Field Methods for Measurement of Fluvial Sediment, Techniques of Water-Resources Investigations, Book 3, US Geological Survey, Reston.

Elliott, S., and B. Sorrell (2002), Lake Managers' Handbook: Land-Water Interactions, Ministry for the Environment, Wellington.

Evans, J. E., J. M. Huxley, and R. K. Vincent (2006), Historical changes in channel sinuosity upstream of a low-head dam, Huron River, North-central Ohio, Geological Society of America Abstracts, 38(4), 20.

eWater CRC (2010), Source Catchments User Guide, eWater Cooperative Research Centre, Canberra.

Fahey, B. D., and M. Marden (2000), Sediment yields from a forested and a pasture catchment, coastal Hawke's Bay, North Island, New Zealand, Journal of Hydrology New Zealand, 39(1), 49-63.

FAO (2007), Coping with water scarcity: Challenge of the twenty-first century, Food and Agriculture Organization and United Nations Water.

Federated Farmers (2008), Water storage is one of the 'magic bullets', Media Release 15 December 2008, Webpage: www.fedfarm.org.nz/n1122.html, accessed 05/01/2009.

Finch, J. W. (1997), Monitoring small dams in semi-arid regions using remote sensing and GIS, Journal of Hydrology, 195, 335-351.

Finkelstein, J. (1973), Survey of New Zealand Tank Evaporation, New Zealand Meteolorological Service, Wellington.

Finlayson, B., J. Nevill, and T. Ladson (2008), Cumulative impacts in water resource development., in Water Down Under Conference 2008, edited by M. Lambert, T. Daniell and M. Leonard, Adelaide.

Fish and Game New Zealand (2009), Water storage is not a silver bullet, Fish and Game NZ National News, Webpage: www.fishandgame.org.nz/Site/Features/ NationalNewsJan09, accessed 08/10/2010.

Flemmer, C. L., and R. C. Flemmer (2007), Water use by New Zealand dairy farms, 1997-2000, New Zealand Journal of Agricultural Research, 50, 479-489. 
Folk, R. L., and W. C. Ward (1957), Brazos River Bar: A study in the significance of grain size parameters, Journal of Sedimentary Research, 27.

Frickel, D. G. (1972), Hydrology and effects of conservation structures, Willow Creek basin, Valley County, Montana 1954-1968, US Geological Survey WaterSupply Paper 1532-G, US Geological Survey.

Gannon, V. P. J., G. D. Duke, J. E. Thomas, J. VanLeeuwen, J. Byrne, D. Johnson, S. W. Kienzle, J. Little, T. Graham, and B. Selinger (2005), Use of in-stream reservoirs to reduce bacterial contamination of rural watersheds, Science of the Total Environment, 348, 19-31.

Gleason, R. A., B. A. Tangen, M. K. Laubhan, K. E. Kermes, and N. H. Euliss, Jr (2007), Estimating water storage capacity of existing and potentially restorable wetland depressions in a subbasin of the Red River of the North, Open File Report 2007-1159, US Geological Survey, Lincoln.

Goldsmith, E., and N. Hildyard (1984), The social and environmental effects of large dams, Wadebridge Ecological Centre, Cornwall.

Good, R. (1992), The impact of development on streamflow in the Marne River, Report ESW 92/23, Engineering and Water Supply Department, Government of South Australia, Adelaide.

Graf, W. L. (1999), Dam nation: A geographic census of American dams and their large-scale hydrologic impacts, Water Resources Research, 35(4), 1305-1311.

Grant, P. J. (1965), Major regime changes of the Tukituki River, Hawke's Bay, since about 1650 AD, Journal of Hydrology New Zealand, 4, 17-30.

Grant, P. J. (1977), Water temperatures of the Ngaruroro River at three stations, Journal of Hydrology New Zealand, 16(2), 148-157.

Grayson, R., R. Argent, R. J. Nathan, T. McMahon, and R. Mein (1996), Hydrological Recipes, Cooperative Research Centre for Catchment Hydrology, Melbourne.

Griffiths, E. (2004), Soils of the Ruataniwha Plains - a guide to their management, Grifftech and Hawke's Bay Regional Council, Napier.

Griffiths, G. M. (2007), Changes in New Zealand daily rainfall extremes 19302004, Weather and Climate, 27, 3-44. 
Gutteridge Haskins \& Davey Pty. Ltd. (1987), Farm dams in catchments study, a report to the Department of Water Resources, Government of Victoria, Melbourne.

Harhcegani, H., and P. Cornish (2003), A catchment approach to understanding the sources and fate of indicator bacteria in an intensive agricultural area, paper presented at Diffuse Pollution Conference, Dublin.

Harris, S., G. Butcher, and W. Smith (2006), The Opuha Dam: An ex post study of its impacts on the provincial economy and community, Aoraki Development Trust.

Hart, M., B. Quin, and M. Nguyen (2004), Phosphorus runoff from agricultural land and direct fertilizer effects: A review, Journal of Environmental Quality, 33, 1954-1972.

Hawke's Bay Regional Council (1998), Sustainable low flow project - Ruataniwha Rivers - Waipawa, Tukipo, Tukituki, Technical Report EMT 98/2, Hawke's Bay Regional Council, Napier.

Hawke's Bay Regional Council (2003), Ruataniwha Plains Water Resources Investigation, HBRC Plan Number 3254, Hawkes Bay Regional Council, Napier.

Hawke's Bay Regional Council (2006a), Hawke's Bay Regional Resource Management Plan, HBRC Plan Number 3881, Hawke's Bay Regional Council, Napier.

Hawke's Bay Regional Council (2006b), Water management review, HBRC Plan Number 3886, Hawke's Bay Regional Council, Napier.

Hawke's Bay Regional Council (2009), The State of our Environment: Summary Report 2008 (2004-2008), HBRC Plan Number 4136, Hawke's Bay Regional Council, Napier.

Hawke's Bay Regional Council (2011), Ruataniwha Water Update, Newsletter 3, Hawke's Bay Regional Council, Napier.

Hazell, D., R. Cunningham, D. Lindenmayer, B. Mackey, and W. Osborne (2001), Use of farm dams as frog habitat in an Australian agricultural landscape: Factors affecting species richness and distribution, Biological Conservation, 102, 155-169.

Heathwaite, A., P. Quinn, and C. Hewett (2005), Modelling and managing critical source areas of diffuse pollution from agricultural land using flow connectivity simulation, Journal of Hydrology, 304, 446-461. 
Heinemann, H. G. (1981), A new sediment trap efficiency curve for small reservoirs, Water Resources Bulletin, 175), 825-830.

Heinemann, H. G., R. F. Holt, and D. L. Rausch (1973), Sediment and nutrient research on selected corn belt reservoirs, in Man-made lakes: their problems and environmental effects, edited by W. C. Ackerman, G. F. White and E. B. Worthington, American Geophysical Union, Washington, DC.

Hicks, D. M., and B. Gomez (2003), Sediment Transport, in Tools in Fluvial Geomorphology, edited by G. M. Kondolf and H. Piegay, pp. 425-461, John Wiley \& Sons, Chichester.

Hoover, R. (2001), Dams Lite? Run of river projects no panacea, World Rivers Review, 16(4).

Hopkins, C. L. (1971), The annual temperature regime of a small stream in New Zealand, Hydrobiologia, 37(3-4), 397-408.

Hossain, M. A., M. Alam, D. R. Yonge, and P. Dutta (2005), Efficiency and flow regime of a highway stormwater detention pond in Washington, USA, Water, Air, and Soil Pollution, 164, 79-89.

Hughes, D. A. (2008), Hydrological information requirements and methods to support the determination of environmental water requirements in ephemeral river systems, report to the Water Research Commission, KV 205/08, Pretoria.

Hume, L., and W. McGimpsey (2009), Water storage for agriculture, paper presented at Dams - Operating in a Regulated Environment, New Zealand Society on Large Dams, Wellington.

Insurance Council of New Zealand (2009), The Cost of Disaster Events, Webpage: www.icnz.org.nz/current/weather, accessed 18/03/2011.

Irish, J. L., and W. J. Lillycrop (1999), Scanning laser mapping of the coastal zone: the SHOALS system, ISPRS Journal of Photogrammetry and Remote Sensing, 54, 123-129.

Jowett, I., and M. J. Duncan (1990), Flow variability in NZ rivers and its relationship to instream habitat and biota, New Zealand Journal of Marine and Freshwater Research, 24, 305-317.

Kennon, K. W. (1966), Hydrologic effects of small reservoirs in Sandstone Creek watershed, Beckham and Roger Mills Counties, Western Oklahoma, USGS Water Supply Paper 1839-C, US Geological Survey, Washington, DC. 
Klemes, V. (1983), Conceptualization and scale in hydrology, Journal of Hydrology, 65, 1-23.

Kondolf, G. M. (1997), Hungry water: effects of dams and gravel mining on river channels, Environmental Management, 21(4), 533-551.

Lampert, W., and U. Sommer (2007), Limnoecology: The ecology of lakes and streams, 2 ed., Oxford University Press, Oxford.

Langland, M. J., J. D. Blomquist, L. A. Sprague, and R. E. Edwards (2000), Trends and status of flow, nutrients, and sediments for selected nontidal sites in the Chesapeake Bay Watershed, 1985-98, US Department of the Interior and US Geological Survey, Lemoyne.

Larinier, M. (2001), Environmental issues, dams and fish migration, in Dams, fish and fisheries: Opportunities, challenges and conflict resolution, edited by G. Marmulla, Food and Agriculture Organization, United Nations, Rome.

Larned, S. T., M. R. Scarsbrook, T. H. Snelder, N. J. Norton, and B. J. F. Biggs (2004), Water quality in low-elevation streams and rivers of New Zealand: Recent state and trends in contrasting land-cover classes, New Zealand Journal of Marine and Freshwater Research, 38, 347-366.

Lawrence, P. (2004), Guidelines for predicting and minimising sedimentation in small dams, report prepared for the British Department for International Development, Report D0152, HR Wallingford, Wallingford.

Lee, H., E. Zehe, and M. Sivapalan (2007), Predictions of rainfall-runoff response and soil moisture dynamics in a microscale catchment using the CREW model, Hydrology and Earth System Sciences, 11, 819-849.

Lessard, J. L., and D. B. Hayes (2003), Effects of elevated water temperature on fish and macroinvertebrate communities below small dams, River Research and Applications, 19, 721-732.

Liebe, J., N. van de Giesen, and M. Andreini (2005), Estimation of small reservoir storage capacities in a semi-arid environment. A case study in the Upper East Region of Ghana, Physics and Chemistry of the Earth, 30, 448-454.

Ligon, F. K., W. E. Dietrich, and W. J. Trush (1995), Downstream ecological effects of dams: A geomorphic perspective, Bioscience, 45(3), 183-192. 
Liu, H., and L. Wang (2008), Mapping detention basins and deriving their spatial attributes from airborne LiDAR data for hydrological applications, Hydrological Processes, 22(13), 2358-2369.

Lloyd, S. D., P. Bishop, and I. Reinfelds (1998), Shoreline erosion: a cautionary note in using small farm dams to determine catchment erosion rates, Earth Surface Processes and Landforms, 23, 905-912.

Lowe, L., and R. J. Nathan (2008), Consideration of uncertainty in the estimation of farm dam impacts, in Water Down Under 2008, edited by M. Lambert, T. Daniell and M. Leonard, Adelaide.

Lowe, L., R. Nathan, and R. Morden (2005), Assessing the impact of farm dams on streamflows, Part II: Regional characterisation, Australian Journal of Water Resources, 9(1), 13-25.

Lowe, W. H., and G. E. Likens (2005), Moving headwater streams to the head of the class, Bioscience, 55(3), 196-197.

Luba, L. (2001), Hawke's Bay Regional Groundwater Summary, in Groundwaters of New Zealand, edited by M. Rosen and P. White, New Zealand Hydrological Society, Wellington.

Ludecke, J. E. (1988), The Tukituki River Catchment - Water and Soil Resource Management Plan, Hawkes Bay Catchment Board and Regional Water Board, Napier.

Maaren, H., and J. Moolman (1985), The effects of farm dams on hydrology, in Proceedings of South African National Hydrological Symposium, pp. 428-441, Department of Agricultural Engineering, University of Natal.

Mantel, S. K., D. A. Hughes, and N. W. Muller (2010), Ecological impacts of small dams on South African rivers, Water South Africa, 36(3), 351-360.

Markwell, K. A., and C. S. Fellows (2008), Habitat and biodiversity of on-farm water storages: A case study in Southeast Queensland, Australia, Environmental Management, 41, 234-249.

Marsh, N., M. Stewardson, and M. Kennard (2003), River Analysis Package, Cooperative Research Centre for Catchment Hydrology, Melbourne.

Maxted, J. R., C. H. McReady, and M. R. Scarsbrook (2005), Effects of small ponds on stream water quality and macroinvertebrate communities, New Zealand Journal of Marine and Freshwater Research, 39, 1069-1084. 
McColl, R., and H. R. Hughes (1981), The effects of land use on water quality - A review, Water and Soil Miscellaneous Publication 23, National Water and Soil Conservation Organisation, Wellington.

McCully, P. (1996), Silenced Rivers: The Ecology and Politics of Large Dams, Zed Books, London.

McDonald, G., and D. M. Patterson (2003), Ecological Footprints of New Zealand and its Regions, Ministry for the Environment, Wellington.

McDowall, R. M. (1993), Implications of diadromy for the structuring and modelling of riverine fish communities in New Zealand, New Zealand Journal of Marine and Freshwater Research, 27, 453-462.

McGuinness, J. M. (1984), Ruataniwha Plains Water Resources Report, Hawkes Bay Catchment Board and Regional Water Board, Napier.

McKerchar, A., and R. Henderson (2003), Shifts in flood and low-flow regimes in New Zealand due to interdecadal climate variations, Hydrological Sciences, 48(4), 637-654.

McKerchar, A. I., U. Shankar, and M. Hicks (2005), Water harvesting: an ideal use of floodwaters?, Water and Atmosphere, 13(2), 24-25.

McMurray, D. (1996), Farm dam storage assessment in the Mount Lofty Ranges, Draft Report VO.4, Department of Environment and Natural Resources, Government of South Australia, Adelaide.

McMurray, D. (2004), Farm dam volume estimations from simple geometric relationships, Report 2006/22, Department of Water, Land and Biodiversity Conservation, Government of South Australia, Adelaide.

McMurray, D. (2006), Impact of farm dams on streamflow in the Tod River catchment, Eyre Peninsula, South Australia, Report 2004/48, Department of Water, and Biodiversity Conservation, Government of South Australia, Adelaide.

Meade, R. H., T. R. Yuzyk, and T. J. Day (1990), Movement and storage of sediment in rivers of the United States and Canada, in Surface Water Hydrology, The Geology of North America, edited by M. Wolman and H. Riggs, pp. 255-280, The Geological Society of America, Boulder.

Meigh, J. (1995), The impact of small farm reservoirs on urban water supplies in Botswana, Natural Resources Forum, 191), 71-83. 
Melbourne Water (2000), The impact of farm dams on Hoddles Creek and Diamond Creek catchments, Final Report 2, Melbourne Water, Melbourne.

Melbourne Water (2002), Estimation of impact of farm dams on streamflows. Stringybark Creek, Project Number VV8916, Melbourne Water, Melbourne.

Mendoza-Lera, C., A. Larranaga, J. Perez, E. Descals, A. Martinez, O. Moya, I. Arostegui, and J. Pozo (2010), Headwater reservoirs weaken terrestrial-aquatic linkage by slowing leaf-litter processing in downstream regulated reaches, River Research and Applications, doi: 10.1002/rra.1434.

Merritt, D. M., and D. J. Cooper (2000), Riparian vegetation and channel change in response to river regulation: A comparative study of regulated and unregulated streams in the Green River Basin, USA, Regulated Rivers: Research and Management, 16, 543-564.

Mialhe, F., Y. Gunnell, and C. Mering (2008), Synoptic assessment of water resource variability in reservoirs by remote sensing: General approach and application to the runoff harvesting systems of south India, Water Resources Research, 44,W05411, doi: 10.1029/2007WR006065.

Ministry for the Environment (1997), The State of New Zealand's Environment 1997, Ministry for the Environment, Wellington.

Ministry for the Environment (2000), Information on water allocation in New Zealand, Report 4375/1, Ministry for the Environment, Wellington.

Ministry for the Environment (2006a), Snapshot of water allocation in New Zealand, Ministry for the Environment, Wellington.

Ministry for the Environment (2006b), Using the cultural health index: How to assess the health of streams and waterways, Report ME 711, Ministry for the Environment, Wellington.

Ministry for the Environment (2007a), Lake water quality in New Zealand. Status in 2006 and recent trends 1990-2006, Report MC 832, Ministry for the Environment, Wellington.

Ministry for the Environment (2007b), Environment New Zealand 2007, Report $M E$ 848, Ministry for the Environment, Wellington.

Ministry for the Environment (2008), Climate Change Effects and Impacts Assessment. A Guidance Manual for Local Government in New Zealand, Ministry for the Environment, Wellington. 
Ministry for the Environment (2009), New Start for Fresh Water, Ministry for the Environment and Ministry of Agriculture and Forestry, Wellington.

Ministry of Works (1971), Hawke's Bay Region, National Resources Survey - Part VI, Ministry of Works; Town and Country Planning Division, Wellington.

Morisawa, M. (1968), Streams: their dynamics and morphology, McGraw-Hill, New York.

Mosley, P., and A. McKerchar (1993), Streamflow, in Handbook of Hydrology, edited by D. R. Maidment, pp. 8.1-8.39, McGraw-Hill, New York.

Mullan, A.B. (1995), On the linearity and stability of southern oscillation climate relationships for New Zealand, International Journal of Climatology 15, 1365-1386.

Mullan, A., M. Salinger, C. Thompson, and A. Porteous (2001), The New Zealand Climate - Present and Future, in The effects of climate change and variation in New Zealand: An assessment using CLIMPACTS, edited by R. Warrick, G. Kenny and J. Harman, pp. 11-31, University of Waikato, Hamilton.

Mullan, B., A. Porteous, D. Wratt, and M. Hollis (2005), Changes in drought risk with climate change, Report WLG 20005-23, prepared for Ministry for the Environment and Ministry of Agriculture and Forestry, National Institute of Water \& Atmospheric Research Ltd, Wellington.

Mulligan, M., and J. Wainwright (2004), Modelling and Model Building, in Environmental Modelling: Finding Simplicity in Complexity, edited by J. Wainwright and M. Mulligan, pp. 7-73, John Wiley \& Sons, Ltd, Chichester.

Murray Darling Basin Commission (2008), Risks to shared water resources: Mapping the growth, location, surface area and age of man made waterbodies, including farm dams, in the Murray-Darling Basin, Agreement Number MD949, Murray-Darling Basin Commission, Geoscience Australia, Canberra.

Nathan, R., B. Neal, W. Smith, and N. Fleming (2000), The impact of farm dams on streamflows in the Marne River catchment, paper presented at Melbourne 2000, Xth World Water Congress, Melbourne.

Nathan, R., P. A. Crowe, and B. Neal (2004), The estimation of farm dam yield in small agricultural catchments in South Eastern Australia, Australian Journal of Water Resources, 8(1), 21-35. 
Nathan, R., P. Jordan, and R. Morden (2005), Assessing the impact of farm dams on streamflows, Part I: Development of simulation tools, Australian Journal of Water Resources, 9(1), 1-11.

National River Health Program (2002), Assessment of the Impact of Private Dams on Seasonal Stream Flows, National River Health Program - Environmental Flows Initiative, Department of Natural Resources and Environment and Melbourne Water, Environment Australia, Canberra.

Neal, B., P. Shephard, K. Austin, and R. J. Nathan (2000), The effect of catchment farm dams on streamflows - Victorian case studies, paper presented at Melbourne 2000, Xth World Water Congress, Melbourne.

Neal, B., R. Nathan, S. Schreider, and A. J. Jakeman (2002), Identifying the separate impact of farm dams and land use changes on catchment yield, Australian Journal of Water Resources, 5(2), 165-175.

Nechvatal, M., and T. Granata (2004), Dam removal as a solution to increase river water quality, in Self-sustaining solutions for streams, wetlands, and watersheds, edited by J.L. D’Ambrosio, American Society of Agricultural and Biological Engineers, St. Joseph, MI.

Neil, D. T., and R. K. Mazari (1993), Sediment yield mapping using small dam sedimentation surveys, Southern Tablelands, New South Wales, Catena, 20,1325.

Newham, L., and J. Drewry (2006), Modelling catchment-scale nutrient generation, Technical Report 28/05, CSIRO Land and Water, Canberra.

Nilsson, C., and K. Berggren (2000), Alterations of riparian ecosystems caused by river regulation, Bioscience, 50(9), 783-792.

Nilsson, C., and M. Svedmark (2002), Basic principles and ecological consequences of changing water regimes: Riparian plant communities, Environmental Management, 30(4), 468-480.

Nilsson, C., R. Jansson, and U. Zinko (1997), Long-term responses of river-margin vegetation to water-level regulation, Science, 276(5313), 798-800.

Ockenden, A., and V. Kotwicki (1982), The effects of farm dams on flows in the Northern Para River, Report EW 3 82/59, Engineering and Water Supply Department, Government of South Australia, Adelaide. 
O'Connor, T. G. (2001), Effect of small catchment dams on downstream vegetation of a seasonal river in semi-arid African savanna, Journal of Applied Ecology, 38, 1314-1325.

Olley, J., and R. J. Wasson (2003), Changes in the flux of sediment in the Upper Murrumbidgee catchment, SE Australia, since European settlement, Hydrological Processes, 17, 3307-3320.

Palmer, R. W., and J. H. O'Keeffe (1990), Downstream effects of impoundments on the water chemistry of the Buffalo River (Eastern Cape), South Africa, Hydrobiologia, 202, 71-83.

Petts, G. E. (1979), Complex response of river channel morphology subsequent to reservoir construction, Progress in Physical Geography, 3, 329-362.

Pikusa, E. (1999), Untitled internal paper on the suitability of farm dam surface area-volume relationships for modelling surface water resources in the Barossa Valley, Government of South Australia, Adelaide.

Pisaniello, J. (2010), The need for 'adequate' farm dam safety management accountability to avoid dam failure emergencies, The Australian Journal of Emergency Management, 25(3), 31-38.

Pitlick, J., and P. R. Wilcock (2001), Relations between streamflow, sediment transport, and aquatic habitat in regulated rivers, in Geomorphic Processes and Riverine Habitat (Water Science and Application, Volume 4), edited by J.M. Dorava, pp. 185-198, American Geophysical Union, Washington, DC.

Pitman, W. V., and R. A. Pullen (1989), The impact of minor dams on the water resources of the Upper Olifants River basin, in Proceedings of the Fourth South African National Hydrology Symposium, edited by S. Kienzle and H. Maaren, pp. 45-54, University of Pretoria, Pretoria.

Quinn, J. M., and M. J. Stroud (2002), Water quality and sediment and nutrient export from New Zealand hill-land catchments of contrasting land use, New Zealand Journal of Marine and Freshwater Research, 36, 409-429.

Quinn, P. F., C. J. Hewett, and A. Doyle (2004), Scale appropriate modelling: From mechanisms to management, in Scales in Hydrology and Water Management, Volume 287, edited by I. Tchiguirinskaia, M. Bonell and P. Hubert, pp. 17-37, International Association of Hydrological Sciences.

Richards, K. (1982), Rivers: Form and Process in Alluvial Channels, The Blackburn Press, Caldwell, NJ. 
Robb, C. (2001), Water allocation: A strategic overview, Report 4455/1, Ministry for the Environment, Wellington.

Rosenberg, D. M., P. McCully, and C. M. Pringle (2000), Global-scale environmental effects of hydrological alterations: Introduction, Bioscience, 50(9), 746-751.

Rutherford, K. (2009), Catchment sensitivity, nutrient limits, nutrient spiralling \& forecasting future landuse impacts in Hawke's Bay, NIWA Client Report HAM2009-001, prepared for Hawke's Bay Regional Council, National Institute of Water \& Atmospheric Research Ltd, Hamilton.

Sahagian, D. (2000), Global physical effects of anthropogenic hydrological alterations: Sea level and water redistribution, Global and Planetary Change 25, 39-48.

Saila, S. B., D. Poyer, and D. Aube (2005), Small dams and habitat quality in low order streams, Wood Pawcatuck Watershed Association, Hope Valley, Rhode Island.

St.Louis, V. L., C. A. Kelly, E. Duchemin, J. W. M. Rudd, and D. M. Rosenberg (2000), Reservoir surfaces as sources of greenhouse gases to the atmosphere: A global estimate, Bioscience, 50(9), 766-775.

Salinger, J., W. Gray, B. Mullan, and D. Wratt (2004), Atmospheric circulation and precipitation, in Freshwaters of New Zealand, edited by J. Harding, P. Mosley, C. Pearson and B. Sorrell, pp. 2.1-2.18, New Zealand Hydrological Society and New Zealand Limnological Society, Christchurch.

Santucci, V. J. J., S. R. Gephard, and S. M. Pescitelli (2005), Effects of multiple low-head dams on fish, macroinvertebrates, habitat, and water quality in the Fox River, Illinois, North American Journal of Fisheries Management, 25, 975-992.

Savadamuthu, K. (2002), Impact of farm dams on streamflow in the Upper Marne catchment, Report DWR 01/01/0003, Department for Water Resources, Government of South Australia, Adelaide.

Savadamuthu, K. (2003), Surface water assessment of the upper Finniss catchment, South Australia, Report 2003/18, Department of Water, Land, and Biodiversity Conservation, Government of South Australia, Adelaide.

Schreider, S., A. J. Jakeman, R. A. Letcher, R. Nathan, B. P. Neal, and S. G. Beavis (2002), Detecting changes in streamflow response to changes in non-climatic 
catchment conditions: Farm dam development in the Murray-Darling basin, Australia, Journal of Hydrology, 262, 84-98.

Schumm, S. A. (1977), The Fluvial System, John Wiley \& Sons, New York.

Schwendel, A. C., I. C. Fuller, and R. G. Death (2010), Morphological dynamics of upland headwater streams in the southern North Island of New Zealand, New Zealand Geographer, 66, 14-32.

Shuman, J. R. (1995), Environmental considerations for assessing dam removal alternatives for river restoration, Regulated Rivers: Research and Management, 11, 249-261.

Sinclair Knight Merz (2001), South Para Farm Dams, Impact of Farm Dam Modelling, report prepared for Northern Adelaide \& Barossa Catchment Water Management Board, Sinclair Knight Merz, Armadale, Australia.

Sinclair Knight Merz (2002), Assessing the Impacts of Farm Dams on Streamflows: TEDI User Manual, 3 ed., Sinclair Knight Merz.

Sinclair Knight Merz (2004), An assessment of water use and environmental flow requirements for the Moorabool River, report prepared for Corangamite Catchment Management Authority, Victoria, Sinclair Knight Merz.

Sinclair Knight Merz (2008), Background report: Farm dam interception in the Campaspe Basin under climate change, Sinclair Knight Merz, Malvern, Australia.

Smith, S. V., W. H. Renwick, J. D. Bartley, and R. W. Buddemeier (2002), Distribution and significance of small, artificial water bodies across the United States landscape, The Science of the Total Environment, 299, 21-36.

Soulsby, C., C. Neal, H. Laudon, D. Burns, P. Merot, M. Bonell, S. Dunn, and D. Tetzlaff (2008), Catchment data for process conceptualization: Simply not enough?, Hydrological Processes, 22, 2057-2061.

Srikanthan, R., and D. T. Neil (1989), Simulation of the effect of farm dams on sediment yield from two small rural catchments, Australian Journal of Soil and Water Conservation, 2(1), 40-45.

Stanley, E. H., and M. W. Doyle (2002), A geomorphic perspective on nutrient retention following dam removal, Bioscience, 52(8), 693-701. 
Stephens, U. (1964), Effects of conservation techniques on yield, Journal of the American Water Works Association, as cited in R. Srikanthan and D. T. Neil (1989) above.

Stewart, G., and R. Rout (2007), Reasonable stock water requirements: Guidelines for resource consent applications, Technical Report, Horizons Regional Council, Palmerston North.

Strayer, D. L., R. E. Beighley, L. C. Thompson, S. Brooks, C. Nilsson, G. Pinay, and R. J. Naiman (2003), Effects of land cover on stream ecosystems: Roles of empirical models and scaling issues, Ecosystems, 6, 407-423.

Steefel, C. I., and P. Van Cappellen (1998), Reactive transport modeling of natural systems, Journal of Hydrology, 209, 1-7.

Surian, N., and M. Rinaldi (2004), Channel adjustments in response to human alteration of sediment fluxes: examples from Italian rivers, in Sediment transfer through the fluvial system, edited by V. Golosov, V. Belyaev and D. E. Walling, pp. 276-282, International Association of Hydrological Sciences, Wallingford.

Szesztay, K. (1973), Summary: Hydrology and Man-Made Lakes, in Man-Made Lakes: Their Problems and Environmental Effects, edited by W. C. Ackerman, G. F. White and E. B. Worthington, pp. 259-263, American Geophysical Union, Washington, DC.

Tarboton, K., and K. Schulze (1991), The "ACRU" modelling system for large catchment water resources management, in Hydrology for the Water Management of Large River Basins, edited by F. van de Ven, D. Gutknecht, D. Loucks and K. Salewicz, pp. 219-232, International Association of Hydrological Sciences, Wallingford.

Taube, C. (2000), Three methods for computing the volume of a lake, in Manual of Fisheries Methods II: with periodic updates. Fisheries Special Report 25, edited by J. Schneider, Michigan Department of Natural Resources, Ann Arbor.

Teoh, K. S. (2002), Estimating the impact of current farm dam development on the surface water resources of the Onkaparinga River Catchment, Report 2002/22, Department of Water, Land and Biodiversity Conservation, Government of South Australia, Adelaide.

Thompson, C. S. (1985), Maps of rainfall parameters for New Zealand, Miscellaneous Publication, New Zealand Meteorological Service, Wellington. 
Toleman, I. (1999), Channel changes in the Upper Waipawa River, Ruahine Range, 1977-1997, BSc Honours thesis, Institute of Geography, Victoria University of Wellington, Wellington.

Tonkin and Taylor Ltd (2009), Prefeasibility Study of Water Augmentation Opportunities - Ruataniwha Plains, Report 25916.000, prepared for Hawke's Bay Regional Council, Tonkin and Taylor Ltd, Wellington.

United States Bureau of Reclamation (1977), Design of Small Dams, USBR, Denver.

United States Department of Agriculture (1981), Soil, water, and related resources in the United States: Status, conditions, and trends, USDA, Washington, DC.

Unkefer, C. (2008), Shasta River dam removal benefits all, Shasta Valley Resource Conservation District, Yreka, CA, Webpage: http://svrcd.org/wordpress/wpcontent/uploads/2011/05/Araujo.pdf, accessed 11/05/2011.

Unkefer, C. (2009), Shasta river irrigation project: good news on the Klamath, in Siskiyou Daily News, 02/09/2009, Yreka, CA.

Van Dijk, A., R. Evens, P. Hairsine, S. Khan, R. Nathan, Z. Paydar, N. Viney, and L. Zhang (2006), Risks to the shared water resources of the Murray-Darling Basin, Publication Number 22/06, Murray-Darling Basin Commission, Canberra.

Van Oost, K., G. Govers, and P. Desmet (2000), Evaluating the effects of changes in landscape structure on soil erosion by water and tillage, Landscape Ecology, 15, 577-589.

Van Steeter, M. M., and J. Pitlick (1998), Geomorphology and endangered fish habitats of the upper Colorado River. 1. Historic changes in streamflow, sediment load, and channel morphology, Water Resources Research, 34(2), 287-302.

Vanoni, V. A. (Ed.) (1975), Sedimentation Engineering, American Society of Civil Engineers, Reston.

Verstraeten, G., and J. Poesen (2000), Estimating trap efficiency of small reservoirs and ponds: Methods and implications for the assessment of sediment yield, Progress in Physical Geography, 24(2), 219-251.

Verstraeten, G., and J. Poesen (2001), Modelling the long-term sediment trap efficiency of small ponds, Hydrological Processes, 15, 2797-2819. 
Verstraeten, G., and I. P. Prosser (2008), Modelling the impact of land-use change and farm dam construction on hillslope sediment delivery to rivers at the regional scale, Geomorphology, 98, 199-212.

Wakefield, B., H. Taungakore, K. Steffert, J. Maaka, C. Marunui, and U. Te Aho (2010), Cultural impact assessment of the Tukituki proposed water storage dams, Te Manga Maori, Eastern Institute of Technology, Gisborne.

Walling, D. E. (1983), The sediment delivery problem, Journal of Hydrology, 65, 209-237.

Ward, J. V., and J. A. Stanford (1995), Ecological connectivity in alluvial river ecosystems and its disruption by flow regulation, Regulated Rivers: Research and Management, 11, 105-119.

Warner, R. (1983), Channel changes in the sandstone and shale reaches of the Nepean River, NSW, in Aspects of Australian Sandstone Landscapes, edited by R. Young and G. Nanson, pp. 106-119, Australian and New Zealand Geomorphology Group, University of Wollongong, Wollongong.

Wiens, L. (2001), A surface area-volume relationship for prairie wetlands in the upper Assiniboine river basin, Saskatchewan, Canadian Water Resources Journal 26, 503-513.

Wilcock, R. J., R. M. Managhan, J. M. Quinn, A. M. Campbell, B. S. Thorvold, M. J. Duncan, A. W. McGowan, and K. Betteridge (2006), Land-use impacts and water quality targets in the intensive dairying catchment of the Toenepi Stream, New Zealand, New Zealand Journal of Marine and Freshwater Research, 40, 123140 .

Williams, G. J. (1985), Upper Tukituki Catchment Control Scheme, Hawkes Bay Catchment Board and Regional Water Board, Napier.

Williams, G. P., and M. G. Wolman (1984), Downstream effects of dams on alluvial rivers, USGS Professional Paper 1286, US Geological Survey, Washington, DC.

Wood, E. F., M. Sivapalan, K. Beven, and L. Band (1988), Effects of spatial variability and scale with implications to hydrologic modeling, Journal of Hydrology, 102, 29-47.

Wood, G. (2003), State of environment report on Hawke's Bay climate, 2003, Hawke's Bay Regional Council, Napier. 
World Commission on Dams (2000), Dams and Development: A new framework for decision-making, Earthscan Publications Ltd, London.

Yorke, T. H., J. K. Stamer, and G. L. Pederson (1985), Effects of low-level dams on the distribution of sediment, trace metals, and organic substances in the Lower Schuylkill River Basin, Pennsylvania, USGS Water Supply Paper 2256-B, US Geological Survey, Washington, DC. 